\title{
AGRICULTURA E ESTRUTURA PRODUTIVA DO ESTADO DO MATO GROSSO: UMA ANÁLISE INSUMO-PRODUTO
}

\author{
Margarida GarCia de Figueiredo
}

Dissertação apresentada à Escola Superior de

Agricultura "Luiz de Queiroz", Universidade de São Paulo, para obtenção do título de Mestre em Ciências, Área de Concentração: Economia Aplicada.

P I R A C I C A B A

Estado de São Paulo - Brasil

Novembro - 2003 


\title{
AGRICULTURA E ESTRUTURA PRODUTIVA DO ESTADO DO MATO GROSSO: UMA ANÁLISE INSUMO-PRODUTO
}

\author{
Margarida Garcia de FigueIREDo \\ Engenheiro Agrônomo
}

Orientador: Prof. Dr. AleXandre LAHóz MENDOnÇA DE BARRoS

Dissertação apresentada à Escola Superior de

Agricultura "Luiz de Queiroz", Universidade de São

Paulo, para obtenção do título de Mestre em Ciências, Área de Concentração: Economia Aplicada.

P I R A C I C A B A

Estado de São Paulo - Brasil

Novembro - 2003 

Dados Internacionais de Catalogação na Publicação (CIP)
DIVISÃO DE BIBLIOTECA E DOCUMENTAÇÃO - ESALQ/USP

\author{
Figueiredo, M argarida Garcia de \\ A gricultura e estrutura produtiva do Estado do $M$ ato Grosso : uma análise \\ insumo-produto / M argarida Garcia de Figueiredo. - - Piracicaba, 2003. \\ $188 \mathrm{p}$. \\ Dissertação (mestrado) - - Escola Superior de Agricultura Luiz de Queiroz, \\ 2003. \\ Bibliografia. \\ 1. Setor primário 2. Produção agrícola 3. Insumo-produto I. Título
}

CDD 338.1

"Permitida a cópia total ou parcial deste documento, desde que citada a fonte - O autor" 
Ao meu marido, meus pais, irmãos e cunhado. 


\section{AGRADECIMENTOS}

Meus sinceros agradecimentos ao Antônio, Lanya, Luiz Eduardo, Mariana, Antônio Cândido e Carolina, por constituírem minha família, que tanto me apoiou em mais esta etapa.

Ao meu marido Euro, por ter acompanhado cada passo com grande incentivo e companheirismo.

A minha prima Ana Luisa, pela colaboração com o inglês.

Ao professor Alexandre Lahóz Mendonça de Barros, pela orientação dedicada e competente, além da amizade, contribuindo não só para a realização desta pesquisa mas também para minha formação profissional.

Ao professor Joaquim José Martins Guilhoto, responsável por grande parte de meu aprendizado neste período, além da contribuição ao desenvolvimento de minha pesquisa.

Aos professores Francisco Constantino Crocomo e José Vicente Caixeta Filho, contribuindo com críticas e sugestões, enriquecendo dessa maneira, o conteúdo desta dissertação.

Ao professor Sérgio De Zen, pela amizade e contribuição com informações relevantes ao trabalho.

Aos professores do Departamento de Economia, Administração e Sociologia, pelos ensinamentos recebidos.

À todos os componentes da equipe "Projeções Econômicas", com os quais estive trabalhando e aprendendo muita coisa, além de terem contribuído para o desenvolvimento do trabalho.

Aos meus colegas de pós graduação pelo convívio durante o curso.

Aos funcionários do Departamento de Economia, Administração e Sociologia, em 
especial: Maielli, Pedro, Luciane, Ligiana, Álvaro, Helena, Márcia e Maria, pela colaboração em todos os momentos do curso.

Ao CNPq pelo apoio financeiro.

Enfim, a todas as pessoas envolvidas na realização desta pesquisa. 


\section{SUMÁRIO}

Página

LISTA DE FIGURAS ...................................................................... ix

LISTA DE QUADROS......................................................................

LISTA DE TABELAS...........................................................................

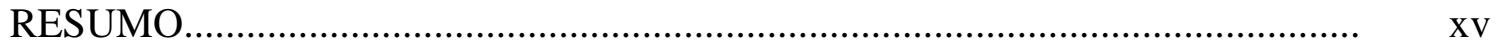

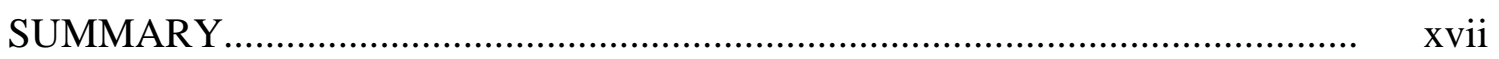

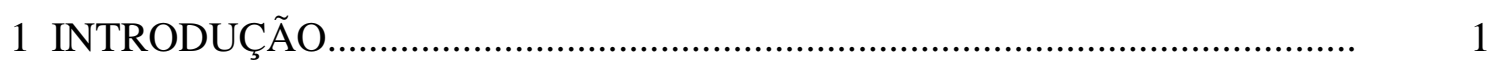

$1.1 \mathrm{O}$ problema e sua importância............................................................... 1

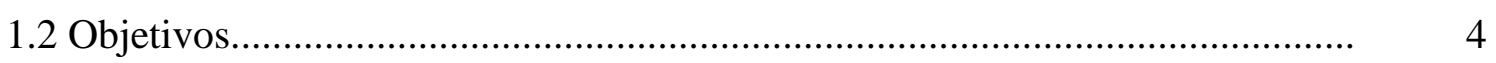

1.3 Organização do trabalho......................................................................... 5

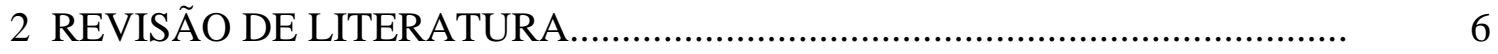

2.1 Os papéis da agricultura no desenvolvimento econômico de um país............... 6

2.2 A agricultura no Brasil ao longo das três últimas décadas.............................. 10

2.3 O Desenvolvimento da região Centro-Oeste no Brasil................................... 15

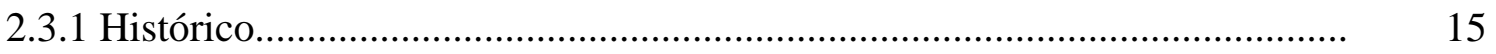

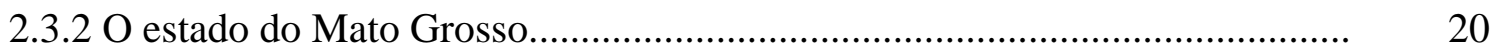

2.3.2.1 A divisão do estado do Mato Grosso......................................................... 22

2.3.2.2. O estado do Mato Grosso após a divisão..................................................... 22

2.3.2.3 Características agropecuárias do estado do Mato Grosso........................... 24

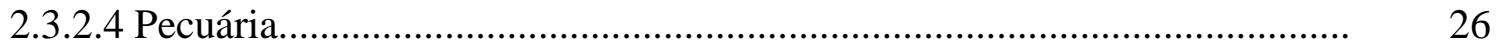

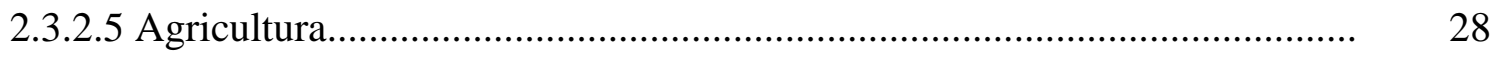

2.4 O setor produtivo da soja no Brasil............................................................ 34

2.5 Transporte de cargas agrícolas no Brasil.......................................................... 41

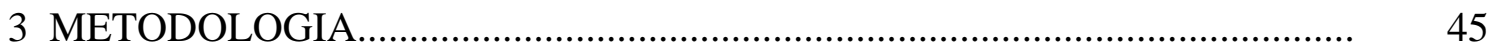




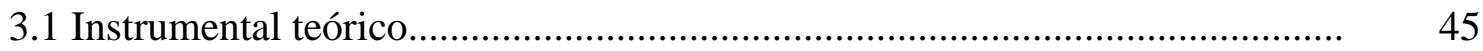

3.1.1 A teoria de análise insumo-produto.........................................................

3.1.1.1 Fundamentos da análise insumo-produto.................................................. 47

3.1.1.1.1 Notação e relações fundamentais.......................................................... 47

3.1.1.1.2 Organização dos dados de Insumo-Produto............................................. 51

3.1.1.2 Modelos de insumo-produto regionais....................................................... 55

3.1.1.2.1 Modelos de insumo-produto regionais (uma única região)...................... 56

3.1.1.2.2 Modelos de insumo-produto inter-regionais (mais de uma região)........ 57

3.1.1.3 Métodos de análise da estrutura produtiva................................................... $\quad 60$

3.1.1.3.1 Índices ligações intersetoriais e setores-chave.......................................... 61

3.1.1.3.1.1 Índices de Rasmussen-Hirschman........................................................ 61

3.1.1.3.1.2 Índices puros de ligações: modelo GHS............................................... 62

3.1.1.3.2 Campo de influência............................................................................. 65

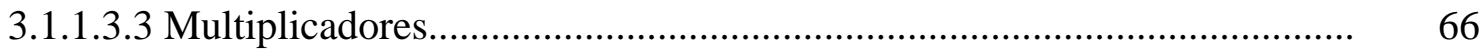

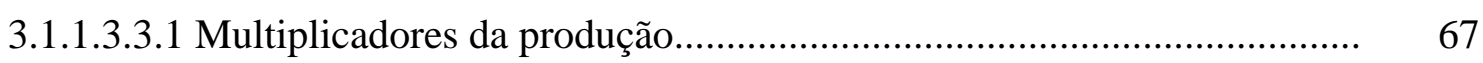

3.1.1.3.3.2 Multiplicadores da renda................................................................... 68

3.1.1.3.3.3 Multiplicadores do emprego................................................................ 69

3.2 Fonte de dados e procedimentos adotados.......................................................... $\quad 70$

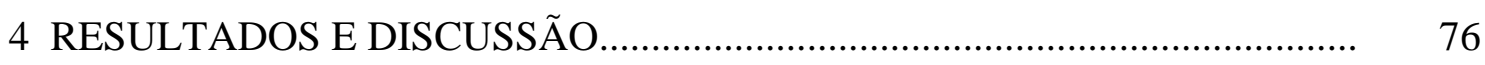

4.1 Índices de ligações intersetoriais................................................................... 76

4.1.1 Índices de Rasmussen-Hirschman................................................................ 77

4.1.2 Índices puros de ligações normalizados.......................................................... 85

4.2 Coeficientes do Campo de Influência............................................................... 96

4.3 Multiplicadores...................................................................................... 99

4.3.1 Geração de emprego................................................................................. 100

4.3.2 Geração de renda........................................................................................ 111

4.3.3 Multiplicador da Produção........................................................................ 120

4.4 Indicadores econômicos para o setor da soja no estado do Mato Grosso.......... 125

4.5 Impacto sobre a produção dos setores de transporte rodoviário e ferroviário... 138

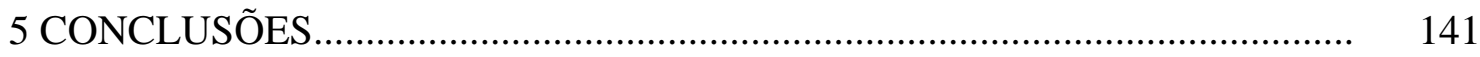


REFERÊNCIAS BIBLIOGRÁFICAS .......................................................... 145

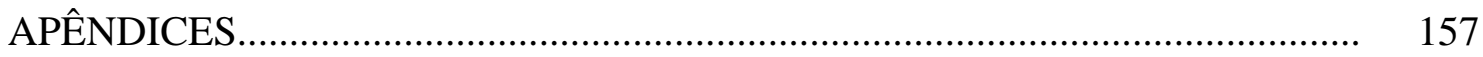




\section{LISTA DE FIGURAS}

Página

1 Índice de Hirschman-Rasmussen para trás (Mato Grosso)................................. $\quad 81$

2 Índice de Hirschman-Rasmussen para trás (Resto do Brasil)............................... 82

3 Índice de Hirschman-Rasmussen para frente (Mato Grosso)............................. 83

4 Índice de Hirschman-Rasmussen para frente (Resto do Brasil)......................... 84

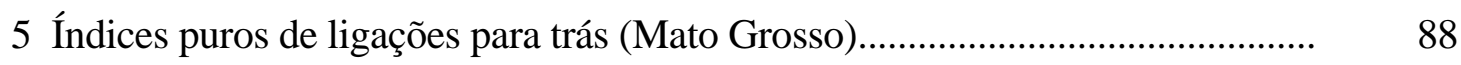

6 Índices puros de ligações para trás (Resto do Brasil)...................................... 89

7 Índices puros de ligações para frente (Mato Grosso).......................................... 90

8 Índices puros de ligações para frente (Resto do Brasil)...................................... 93

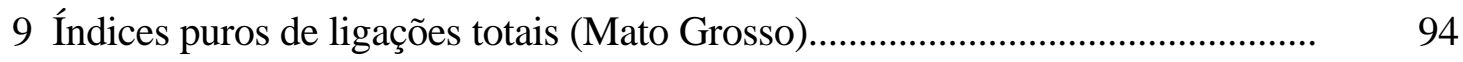

10 Índices puros de ligações totais (Resto do Brasil)............................................. 95

11 Campo de influência para o estado do Mato Grosso...................................... 97

12 Campo de influência para o resto do Brasil................................................... 98 


\section{LISTA DE QUADROS}

Página

1 Exemplo de uma tabela de insumo-produto...................................................... 47

2 Tabela de recursos e usos........................................................................... 52

3 Representação esquemática dos dados em um modelo insumo-produto.................. 53

4 Comparação entre a classificação de setores do IBGE e a utilizada no

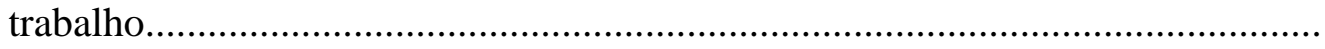




\section{LISTA DE TABELAS}

Página

1 Taxas médias anuais de crescimento e índices de instabilidade do Produto Interno Bruto para diferentes períodos compreendidos entre 1960 e $1996 \ldots \ldots \ldots . . \quad 16$

2 Área e produção de grãos por região do Brasil (em milhões de ha e toneladas).

3 População do estado do Mato Grosso (habitantes).

4 População residente no Mato Grosso (número de pessoascom cinco anos ou mais

5 Estabelecimentos de saúde no Brasil, Centro-Oeste e Mato Grosso $1980 / 2002$.

6 Proporção do número e da área dos estabelecimentos, por grupos de área total - Mato Grosso (1970/1995).

7 Dados de uso da terra dos censos agropecuários - Mato Grosso 1985/1996.

8 Rebanho bovino no Mato Grosso (número de cabeças). 
9 População bovina nos dez municípios com maior rebanho no estado do Mato

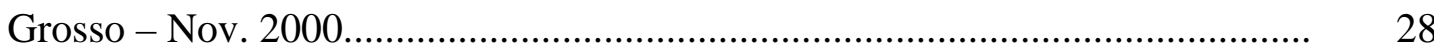

10 Áreas cultivadas com as principais lavouras no Mato Grosso (ha).................. 29

11 Participação das culturas em áreas cultivadas no Mato Grosso (\%).................. 29

12 Produção das principais culturas no Mato Grosso (t).................................... 30

13 Produtividade das principais culturas no Mato Grosso (t / ha)........................ 31

14 Evolução da produção de soja no MT e no Brasil em milhões de toneladas.....

15 Participação dos estados na produção de algumas lavouras no Brasil (em \%) em 1995/1996.

16 Fluxos inter-setoriais e inter-regionais para as regiões L e M

17 Índices de Hirschman-Rasmussen para o Mato Grosso.

18 Índices de Hirschman-Rasmussen para o Resto do Brasil................................

19 Índices puros de ligações normalizados para o Mato Grosso.

20 Índices puros de ligações normalizados para o Resto do Brasil.

21 Geração de emprego total para a variação de um milhão de reais da demanda final. 
22 Geração de empregos diretos, indiretos e induzidos para a variação de um

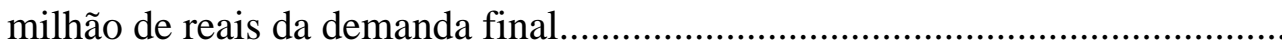

23 Multiplicadores de emprego tipos I e II para o Mato Grosso.

24 Multiplicadores de emprego tipos I e II para o resto do Brasil.

25 Geração de renda total para a variação de um milhão de reais da demanda final

26 Geração de renda direta, indireta e induzida para a variação de um milhão de reais da demanda final

27 Multiplicadores de renda tipos I e II para o Mato Grosso

28 Multiplicadores de renda tipos I e II para o resto do Brasil.

29 Multiplicadores de produção tipos I e II para o Mato Grosso.

30 Multiplicadores de produção tipos I e II para o resto do Brasil.

124

31 Exportações (em mil Reais) do Mato Grosso no ano de 1999

32 Produção (em mil Reais) e valor Adicionado (em mil Reais) gerados na economia ao atender as exportações do Mato Grosso.

33 Número de empregos gerados na economia ao atender as exportações do Mato Grosso. 
34 Produção (em mil Reais) e valor adicionado (em mil Reais) gerados na economia ao atender as exportações de soja do Mato Grosso......................

35 Número de empregos gerados na economia ao atender as exportações de soja

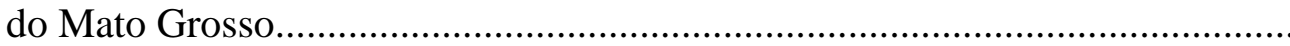

36 Impacto sobre a produção (em mil Reais), valor adicionado (em mil Reais) e quantidade de empregos gerados no Mato Grosso, dado um aumento em $10 \%$ das exportações de soja do Mato Grosso...................................................

37 Impacto sobre a produção (em mil Reais), valor adicionado (em mil Reais) e quantidade de empregos gerados no resto do Brasil, dado um aumento em

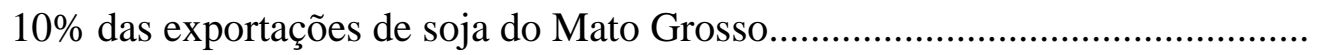

38 Impacto da demanda final de um milhão de Reais de cada setor do Mato Grosso sobre a produção (em mil Reais) dos setores de transporte na economia. 


\title{
AGRICULTURA E ESTRUTURA PRODUTIVA DO ESTADO DO MATO GROSSO: UMA ANÁLISE INSUMO-PRODUTO
}

\author{
Autora: MARGARIDA GARCIA DE FIGUEIREDO \\ Orientador: Prof. Dr. ALEXANDRE LAHÓZ MENDONÇA DE BARROS
}

\section{RESUMO}

O presente trabalho tem como principal objetivo mostrar de forma empírica a importância relativa do setor agrícola na estrutura produtiva do estado do Mato Grosso, o qual tem apresentado um excepcional desempenho da atividade agrícola no contexto atual. Para tanto, utiliza-se de um modelo insumo-produto inter-regional construído para duas regiões, a saber, Mato Grosso e resto do Brasil, referente ao ano de 1999. A partir dos indicadores desta metodologia, procura-se identificar os setores mais importantes das economias em questão, seus encadeamentos e a propagação de impactos entre as regiões. Além disso, o trabalho faz ainda uma aplicação do modelo para verificar qual o impacto das exportações mato-grossenses, em especial da soja, sobre a produção total, valor adicionado e número de empregos gerados na economia, bem como calcula o PIB do agronegócio da soja no Mato Grosso, além de verificar qual o impacto causado na produção dos transportes rodoviário e ferroviário, nas duas regiões, ao atender a demanda final de cada atividade pertencente ao estado do Mato Grosso. Pelos resultados obtidos, pode-se confirmar a hipótese formulada a respeito da importância dos setores 
primários para a economia do estado. De acordo com os índices puros de ligações, verificou-se que os setores agrícolas como Soja, Bovinos e Outros da pecuária, foram considerados como chave ou pólos de desenvolvimento econômico na região em estudo, em função de suas fortes relações de compra e venda de insumos na economia. Além destes, quatro setores diretamente relacionados à agropecuária foram também identificados como chave, a saber: Fabricação de óleos vegetais, Abate de bovinos, Abate de outros animais e Álcool. Em especial merece destaque a cultura da soja no Mato Grosso, que embora tenha uma baixa geração direta de emprego e renda, apresenta um elevado efeito multiplicador destas variáveis na economia, uma característica intrínseca de setores altamente produtivos e intensivos em capital, além de destacar-se também como pólo de desenvolvimento econômico em função de suas fortes ligações, conforme mencionado no parágrafo anterior. As evidências empíricas confirmaram também a importância do setor em termos de suas exportações, as quais causam importante impacto na produção e geração de empregos em diversos outros setores, além de atrair ganhos cambiais ao país. Finalmente, o trabalho desenvolve um ferramental útil para a formulação de políticas públicas para o estado do Mato Grosso, embora sejam necessárias algumas atualizações e refinamentos da metodologia utilizada, para que se possa desenvolver um instrumental de avaliação de políticas de estímulo ao desenvolvimento da infra-estrutura de transportes da região, uma vez que esta última constitui-se peça fundamental ao crescimento econômico. 


\title{
AGRICULTURE AND PRODUCTIVE FRAMEWORK OF MATO GROSSO STATE: AN INPUT-OUTUP ANALYSIS
}

\author{
Author: MARGARIDA GARCIA DE FIGUEIREDO \\ Adviser: Prof. Dr. ALEXANDRE LAHÓZ MENDONÇA DE BARROS
}

\section{SUMMARY}

The main goal of this study is to show the empiric frame of the relative importance of agricultural sector into the productive framework of the Mato Grosso State, which has shown an exceptional agricultural activities growth in the actual context. For this purposes, it becomes useful to adopt an inter-regional input-output model built for two regions: Mato Grosso State and rest of Brazil, regarding to 1999. From the indicators of this methodology, it looks for finding the more important sectors of those economies, and its linkages and impacts between the regions as well. Moreover, this study even encourages to make some simulations to verify how the Mato Grosso's exportations impacts on the total product, income and employment, specially those ones originated from soybean. It was possible to calculate the Mato Grosso's soybean agribusiness GDP (Gross Domestic Product), besides verifying how much impacts were generated on highways and railways transports. According to results obtained, it is possible to confirm the created hypotheses regarding importance of primary sectors for the state economy. According to pure linkages indexes, it was checked that some sectors 
such soybean production, beef cattle production and other ones were considered like key sectors or economic developed pools for the region studied. In addition of those ones, four other sectors directly linked with agriculture were also found out like key sectors, so they are vegetable oils production, beef cattle and other slaughters, and alcohol production. The soybean crops is really a spot in Mato Grosso State, even though it has a low generation of directs income and employment. As a matter of fact, the soybean crops have a high multiplier effect on these economy variables, an own feature of highly productive and capital intensive sectors, and it is a prominence sector like a developing economic pool, as seen before. The empiric evidences confirmed the importance of sector in terms of its exportations too, which strongly impacts on product and employments generation in other ones sectors, besides attracting exchanges gains to the country. Finally, this input-output analysis creates an important tool to the public policy formulations of Mato Grosso State, although its important to make some updates and fits on the methodology applied to be able developing a whole evaluation instrumental kit of entire stimulant policies that might develop for example an efficient regional transport structure, due to this one consists of an essential device to the economic growth. 


\section{INTRODUÇÃO}

\subsection{O problema e sua importância}

A importância da agricultura para o crescimento econômico de um país sempre foi um tópico de grande relavância dentro da teoria econômica. Os economistas clássicos já estudavam os diversos papéis a serem desempenhados pela agricultura no curso do processo de desenvolvimento econômico; e os contemporâneos o fazem nos dias atuais.

Moura et al. (1999) realizaram estudos mostrando que o setor agrícola, ao ser estimulado, pode gerar um efeito benéfico para o resto da economia, ou seja, emana efeitos indutores positivos para os demais setores. Além disso, mostram que ao priorizar as atividades no setor como "mola propulsora" do crescimento econômico, um país estará fazendo uma opção por um grau mais elevado de eficiência na alocação de seus recursos, principalmente no caso de um país que ainda não atingiu os padrões de desenvolvimento econômico considerados como satisfatórios.

Em um país em desenvolvimento como o Brasil, a importância do setor é bastante significativa, conforme se espera. Em 2001, o PIB do setor agropecuário brasileiro de R \$ 99,40 bilhões, segundo dados da Confederação Nacional da Agricultura e Pecuária em parceria com o Centro de Estudos Avançados em Economia Aplicada da Universidade de São Paulo (CNA/CEPEA-USP, 2003), contribuiu com cerca de $8 \%$ na formação do PIB nacional, que de acordo com dados das Contas Nacionais, divulgadas pelo Instituto Brasileiro de Geografia e Estatística (IBGE, 2003), foi de R \$ 1.200,06 bilhões em preços correntes de 2001. Além disso, o PIB do agronegócio brasileiro, que inclui desde a produção primária até a indústria de processamento, insumos e serviços, foi de $\mathrm{R} \$ 344,95$ bilhões em 2001, representando cerca de $28 \%$ do PIB nacional. 
Responsável por cerca de $23,5 \%$ da oferta global de $\operatorname{soja}^{1}$, de acordo com estatísticas da Food and Agriculture Organization of the United Nations (FAO, 2003), o Brasil ocupa atualmente a posição de segundo maior produtor mundial do grão, perdendo apenas para os Estados Unidos, mas na frente de países como Argentina e China. A expansão da cultura contribuiu para uma série de mudanças na história do país, tendo sido em parte responsável pela aceleração da mecanização das lavouras brasileiras; pela modernização do sistema de transportes; pela expansão da fronteira agrícola; pela profissionalização e incremento do comércio internacional; pela modificação e enriquecimento da dieta alimentar dos brasileiros; pela aceleração da urbanização do país; pela interiorização da população brasileira; pela tecnificação de outras culturas; assim como, impulsionou e interiorizou a agroindústria nacional patrocinando o deslanche da avicultura e da suinocultura brasileiras, conforme destacado em estudo da Empresa Brasileira de Pesquisa Agropecuária (EMBRAPA, 2002).

Deve-se ressaltar ainda a importância da soja no mercado externo, cujas exportações de seu complexo agroindustrial representam em torno de $24 \%$ das exportações do agronegócio brasileiro, e em torno de $10 \%$ de nossas exportações totais, segundo estatísticas da Companhia Nacional do Abastecimento (CONAB, 2003).

Merece destaque neste cenário o estado do Mato Grosso, tanto pelo notável desenvolvimento de suas atividades agrícolas na última década, quanto por sua liderança nacional em termos de produção e produtividade de soja. Sua receita com a exportação de soja em grãos se deu em torno de US\$ 736 milhões em 2002, respondendo por 24,3\% da receita nacional com exportação de soja em grãos, segundo estatísticas do Ministério do Desenvolvimento, Indústria e Comércio Exterior (MDIC, 2003). Em decorrência desta e de várias outras características, torna-se interessante a realização de estudos que venham a quantificar a importância relativa do setor agrícola, destacando-se o setor da soja, dentro da estrutura produtiva do estado.

Existem diversos métodos que procuram mensurar as ligações intersetoriais com o objetivo de identificar setores-chave ou pólos de crescimento em uma economia.

\footnotetext{
${ }^{1}$ Produção brasileira de soja: 41.90 milhões de toneladas, de acordo com dados da Food and Agriculture Organization of the United Nations (FAO, 2003).
} 
Esses métodos estão também associados à idéia de se estabelecer prioridades na alocação de recursos e na estratégia de promoções industriais, pois espera-se que ao alocar recursos em setores identificados como chave, dependendo da política a ser implementada, ocorra um estímulo ao crescimento mais rápido da produção, do emprego e da interdependência econômica, do que se os mesmos recursos fossem alocados em outros setores. Dessa forma, o presente trabalho procura mostrar se a relação do setor agricultura no Mato Grosso com os demais setores existentes no estado e resto do Brasil é realmente importante, caracterizando-o como um setor-chave para a economia do estado.

Os modelos insumo-produto, desenvolvidos por Wassily Lentief, em 1930, em sua concepção teórico-empírica, estabelecem a análise dos grandes agregados macroeconômicos em termos de relações de insumos e produtos, estabelecendo um quadro econômico em que a economia é descrita em termos de circulação, isto é, como um sistema integrado de fluxos e transferências de insumos e produtos de um setor a outro, no qual todos os produtos, de acordo com seu destino, podem ser insumos na medida em que sejam aproveitáveis por outro sistema em cadeia.

Mesmo perante algumas limitações da análise econômica utilizando-se a teoria de insumo-produto, decorrentes de alguns pressupostos básicos impostos para que a mesma possa ser aplicada, esta última tem sido amplamente utilizada para diversas finalidades como, por exemplo, avaliar o impacto de políticas econômicas, distribuição de renda, meio ambiente, dentre várias outras. Além destas, o instrumental tem sido muito utilizado na análise intersetorial, na identificação de setores-chave para o desenvolvimento econômico de uma determinada nação e para analisar a importância de setores específicos dentro de determinadas economias.

Desde a sua criação em 1930, o modelo vem ganhando importância entre os formuladores de políticas econômicas, e no decorrer do tempo, o método de insumoproduto transformou-se em instrumento de planejamento econômico largamente aceito e num importante guia para os tomadores de decisões em um grande número de países. 
Do exposto acima, justifica-se a escolha do Modelo de Insumo-Produto como instrumental teórico utilizado para auferir a importância relativa da agricultura na economia do Mato Grosso.

Finalmente, o crescimento econômico tem sido um dos maiores desafios a serem enfrentados pelos gestores da política econômica dos países, não importando o grau de desenvolvimento em que os mesmos se encontrem. Dessa forma, à medida em que se faz qualquer tentativa de mostrar a importância de variáveis dentro desse processo, tal tarefa torna-se por si mesmo justificável.

\subsection{Objetivos}

Este trabalho tem como principal objetivo mostrar de forma empírica a importância relativa dos setores primários na economia de uma região, utilizando-se como referência o estado do Mato Grosso, o qual tem apresentado um excepcional desempenho da atividade agrícola no contexto atual.

Como objetivos específicos, pretende-se:

* Realizar uma análise da estrutura produtiva do estado do Mato Grosso, utilizando-se como fonte de dados a matriz insumo-produto inter-regional Mato Grosso x resto do Brasil, para o ano de 1999.

* Responder a pergunta central referente ao papel da agricultura na economia do Mato Grosso, tendo como hipótese básica a ser testada, se a agricultura pode ser realmente considerada um setor-chave na atividade econômica do estado.

* Identificar os setores-chave, altamente dependentes do resto da economia, bem como setores cuja produção seja amplamente utilizada pelos demais, através de suas relações de compra e venda de insumos.

* Determinar o impacto de variações da demanda final de cada atividade sobre o nível de produção, salários e número de empregos gerados na economia, bem como qual o impacto da demanda final de cada um dos setores pertencentes ao 
Mato Grosso, sobre a produção dos setores Transporte rodoviário (40) e Transporte ferroviário (42), em ambas as regiões.

Verificar qual a produção necessária em cada setor, bem como qual o valor adicionado e quantidade de empregos totais gerados, no Mato Grosso e no resto do Brasil, de modo a atender tanto as exportações totais do Mato Grosso, quanto as suas exportações de soja. Verificar também qual o efeito gerado nestas variáveis em função do aumento em $10 \%$ do total de soja exportada pelo MT, e finalmente, calcular o PIB do agronegócio da soja no Mato Grosso.

\subsection{Organização do trabalho}

Além desta parte introdutória, este trabalho conta com mais quatro capítulos. O segundo, referente àrevisão de literatura, apresenta considerações a respeito dos papéis da agricultura no desenvolvimento econômico de um país, da agricultura no Brasil ao longo da três últimas décadas e do desenvolvimento da região Centro-Oeste no Brasil, onde inclui-se uma caracterização sócio-econômica do estado do Mato Grosso. Também são realizadas algumas considerações sobre o setor produtivo da soja e a questão do transporte de cargas agrícolas no Brasil.

No terceiro capítulo, a metodologia aparece dividida em duas partes. $\mathrm{Na}$ primeira, um referencial teórico sobre o modelo insumo-produto, incluindo conceitos e cálculos dos métodos de análise da estrutura produtiva de uma economia e dos impactos da demanda final sobre algumas variáveis de interesse. Na segunda parte, apresenta-se uma descrição da fonte de dados utilizada.

No quarto capítulo são apresentados e discutidos os resultados obtidos a partir do modelo anteriormente referido. Por último, no quinto capítulo, são colocadas as conclusões e recomendações finais. 


\section{REVISÃO DE LITERATURA}

\subsection{Os papéis da agricultura no desenvolvimento econômico de um país}

Desde os economistas clássicos até os mais contemporâneos, diversos autores colaboraram e ainda colaboram para o entendimento do papel da agricultura no desenvolvimento econômico de um país.

Kuznets (1964) classifica o papel da agricultura em três tipos de contribuição: produto, mercado e fatores. A contribuição em produto representa o crescimento do produto dentro do próprio setor que, obviamente, colabora para o crescimento do produto nacional. A contribuição em mercado representa o fato de poder contribuir para o crescimento de outros setores ou para a participação da economia como um todo no mercado internacional, incluindo, por exemplo, troca de bens (inclusive insumos) com outros setores domésticos ou externos. Essa contribuição pode ser tão mais expressiva quanto maior for o impacto que tenha nos setores com os quais o comércio é realizado. A contribuição em fatores refere-se à transferência ou empréstimo de recursos a outros setores. Os recursos, neste caso, podem ser capital e trabalho. As transferências de capital podem ser compulsórias, por exemplo, via taxação, ou espontâneas, via empréstimo ou utilização direta de poupança originada no setor agrícola para financiar o crescimento de setores não-agrícolas.

Owen (1975) salienta que existe uma dupla pressão sobre a agricultura, uma de produção (requisição intersetorial de incrementos da produção agrícola) e outra de gastos (requisição de renda agrícola residual para finalidades essencialmente não agrícolas ou sociais). Três aspectos dessa dupla pressão sobre a agricultura foram destacados por Yotopoulos \& Nugent (1976), a saber: (1) saída direta de capital, 
resultando do balanço líquido de compras e vendas do setor agrícola; (2) deterioração dos termos de troca domésticos; e (3) transferência de capital humano via migração.

Segundo Teubal ${ }^{2}$, citado por Alves (2000), a idéia de que a agricultura fornece um excedente disponível para a provisão de capital para outros setores é quase tão velha quanto a economia, e mesmo de acordo com os economistas clássicos, como Smith e Ricardo, para os quais a acumulação de capital era possível graças aos excedentes agrícola e industrial, a agricultura seria o principal fornecedor de fundos para tal acumulação.

Silva, G. (1982), ao analisar alguns modelos teóricos de crescimento econômico, sobre a interação da agricultura e o conjunto do sistema econômico, como Lewis (1954), Ranis \& Fei (1961), Schultz (1965) e Hayami \& Ruttan (1971), chama a atenção para o fato de que a maioria das abordagens tem caráter unidirecional, ou seja, pouca ênfase é atribuída aos objetivos do próprio setor agrícola, falhando em considerar as complementariedades entre setores.

De acordo com os clássicos Johnston e Mellor (1961), a agricultura tem diversos papéis a desempenhar no curso do processo de desenvolvimento econômico, devendo-se destacar os cinco mais importantes: (1) fornecer alimentos para a população total; (2) fornecer capital para economia, especialmente para a expansão do setor não agrícola; (3) fornecer mão-de-obra para o crescimento e diversificação de atividades na economia; (4) fornecer ganhos cambiais com os quais os insumos críticos para o processo de desenvolvimento poderão ser adquiridos no exterior; e, (5) proporcionar um amplo mercado para os produtos do setor não-agrícola.

Martin (1976) e Alves (2000) levantaram a questão de que o papel atribuído à agricultura de constituir mercado consumidor para os produtos não-agrícolas deveria ser requalificado, pois embora continue sendo importante em termos de valor, a composição da cesta muda de bens de consumo para bens de investimento e ou de produção direta (insumos).

\footnotetext{
2 TEUBAL, M. Generation and transfer of an agricultural surplus in Argentina. West Lafayette: Purdue University, 1971.
} 
Segundo Araújo e Schuh (1991), ao mencionar o papel da agricultura no desenvolvimento econômico, deve-se destacar dois pontos, a saber: o primeiro referente à importância relativa da agricultura na maioria dos países de baixa renda, nos quais geralmente de 60 a $70 \%$ da força de trabalho estão empenhados em atividades agrícolas e, pelo menos 50\% do Produto Nacional Bruto (PNB) provêm deste setor, o que destaca a importância relativa da agricultura como ponto de partida para o processo de desenvolvimento, além de sugerir que a agricultura pode ser uma importante fonte de recursos para a expansão dos setores não-agrícolas da economia. $\mathrm{O}$ segundo ponto refere-se ao declínio secular da agricultura, em termos relativos, no processo de desenvolvimento, pois à medida que uma economia se desenvolve, usualmente uma porção cada vez menor do PNB provém desse setor, e um contingente cada vez menor da força de trabalho depende diretamente das atividades agrícolas, o que não implica em redução da importância do setor, entretanto, pode levar a mudança de ênfase quanto aos papéis da agricultura no desenvolvimento econômico.

Alves (2000) concluiu em seu trabalho, dentre outras observações importantes, que a percepção do papel da agricultura no desenvolvimento evoluiu ao longo do tempo, e mostrou que, de uma visão de agricultura como setor passivo, chegou-se a uma abordagem segundo a qual as relações e interações entre a agricultura e os outros setores devem ser necessariamente consideradas. Outro ponto importante diz respeito ao papel da agricultura nos estágios mais avançados do desenvolvimento econômico, pois mesmo perdendo em participação relativa, a agricultura continua sendo estrategicamente essencial, pois sua contribuição não se limita apenas à geração de emprego e renda.

Segundo Schuh (1989), um bom desempenho da agricultura pode estar associado a melhor distribuição de renda, a sustentabilidade do crescimento econômico, geração de recursos no saldo da balança comercial, geração de empregos, balanço energético e produção de alimentos. Em outro trabalho, Schuh (1997) lista como contribuições a geração de divisas, aumento e distribuição da renda real do consumidor quando há expansão da oferta e queda dos preços das "commodities" de consumo doméstico, além de que o benefício social será proporcionalmente maior quanto maior for a parcela da renda gasta com estes produtos. 
Alguns autores, como Little (1982) e Nicholls (1964) fazem distinção entre a contribuição da agricultura no desenvolvimento, dependendo do grau de abertura da economia. Para eles, embora o crescimento da produtividade agrícola seja essencial para o crescimento econômico, tanto em economias fechadas quanto em economias abertas, tal contribuição é menor no caso destas últimas. Em seu trabalho, Nicholls (1964) afirma que para uma economia fechada, aumentos na produtividade da agricultura permitem que o setor libere mão-de-obra, tenha mais renda (aumentando a compra de produtos não-agrícolas) e forneça alimentos à preços que permitam lucratividade àindústria. Em economias abertas, embora o setor agrícola tenha importância na geração de divisas para financiar importações, a contribuição é menor.

Moura et al. (1999), ao realizarem um estudo objetivando mostrar que o desempenho do setor agrícola é primordial para a performance das taxas de crescimento, notadamente em economias ainda em processo de desenvolvimento, observaram que, por representar um dos mais importantes setores produtivos, o papel da agricultura precisa ser compreendido de uma maneira um tanto quanto específica. Ficou evidente ainda que, ao ser estimulado, o setor agrícola pode gerar um efeito benéfico para o resto da economia através de alguns mecanismos, tais como o maior incentivo àutilização de capacidade produtiva e economias de escala, ou seja, há efeitos indutores positivos emanados para os demais setores da economia. Finalmente, concluíram que ao priorizar as atividades no setor como mola propulsora do crescimento econômico, um país estará fazendo uma opção por um grau mais elevado de eficiência na alocação de seus recursos, principalmente quando se trata de um país cujo nível de desenvolvimento econômico ainda não atingiu os padrões considerados como satisfatórios.

No que se refere ao processo de desenvolvimento da economia brasileira é importante notar que ao longo do século passado a agricultura deixou de ser o principal setor em termos de participação na renda e no emprego; a transição para uma economia eminentemente urbana se deu em relativo curto espaço de tempo. É certo que a despeito da redução na participação sobre a renda nacional, o setor não deixou de crescer e cumprir seus papéis no desenvolvimento do país, no sentido de Johnston e Mellor (1961). Em especial, os últimos 30 anos foram marcados por intensa modificação no 
padrão tecnológico da agricultura brasileira, a qual passou a ser caracterizada pelo uso de máquinas agrícolas, fertilizantes, defensivos e sementes melhoradas.

\subsection{A agricultura no Brasil ao longo das três últimas décadas}

De acordo com Pereira (1993), a agricultura brasileira acelerou seu processo de modernização a partir da década de 70, com alteração das bases técnica e econômica da produção agrícola. As políticas de modernização foram fortalecidas por meio do apoio financeiro ao custeio e investimento e da criação da Empresa Brasileira de Pesquisa Agropecuária (EMBRAPA) em 1973, para fornecer a tecnologia agropecuária visando a elevação da produtividade e a redução dos custos de produção.

Segundo Mendonça de Barros e Graham (1978), ao longo da década de 70 constatava-se uma crescente segmentação entre dois grupos de produtos agrícolas no Brasil, os domésticos e os exportáveis, cujo elemento que distinguia um do outro era a formação de preços, dada no mercado interno para os produtos domésticos e no mercado internacional para os exportáveis. Enquanto o setor dos exportáveis apresentava uma elevada taxa de crescimento, o setor doméstico enfrentava um baixo desempenho, acarretando até em uma elevação nos preços dos alimentos componentes da cesta básica, que de acordo com os mesmos autores, poderia ser decorrente inclusive do próprio dinamismo do setor dos exportáveis, uma vez que a produção para exportação gerava um efeito de substituição na composição do produto, acirrando a disputa por fatores de produção.

O principal instrumento de política agrícola utilizado para estimular a produção agropecuária nos anos 70 até o início dos anos 80 foi o crédito rural, que por sua vez teve uma grande expansão a partir da criação do Sistema Nacional de Crédito Rural (SNCR) em 1965. Araújo e Almeida (1996) afirmaram que neste período, havia a predominância de crédito subsidiado, ou seja, com taxas de juros reais negativas, atingindo em muitos casos valores próximos a $40 \%$ ao ano, desencadeando uma excessiva demanda por crédito, que juntamente com a oferta abundante de dinheiro, 
fizeram com que o valor total dos empréstimos alcançasse, algumas vezes, cifras próximas do valor do produto bruto da agricultura.

Um dos objetivos desta política era justamente o de fomentar a modernização da agricultura brasileira, seja compensando o efeito negativo de algumas políticas macroeconômicas sobre o setor e / ou estimulando a demanda por insumos modernos produzidos pela indústria que acabara de se instalar no Brasil, que de fato apresentaram significativo aumento, conforme verificou Barros (1999). O problema era que o forte crescimento nas vendas desses insumos não se via acompanhado de ganhos expressivos de eficiência produtiva e, além disso, existia forte dependência da venda de fertilizantes, máquinas e defensivos em relação ao volume de crédito rural concedido.

Segundo Araújo e Almeida (1996) a estratégia das políticas econômicas adotadas na década de 70 , as quais penalizavam a agricultura em nível macro e compensavam o setor com o crédito fácil e barato, teve um êxito apenas parcial sobre o acelerado crescimento da economia brasileira como um todo e da agricultura em particular neste período, uma vez que embora o uso do crédito tenha revelado uma correlação positiva com alguns indicadores de modernização e com o crescimento da produção, não se pode deixar de lado os aspectos negativos dessa política, agravando alguns problemas estruturais sérios, como por exemplo, a concentração da renda.

A partir de então, a idéia era a de que a política de preços mínimos deveria substituir o crédito rural como política de estímulo a produção agropecuária. Entretanto, o que se observou é que desde meados da década de 80, devido às dificuldades fiscais e de controle da inflação, os subsídios e recursos direcionados à agropecuária foram diminuindo, sugerindo que a partir daí as fontes de crescimento da agricultura deveriam ser bastante distintas daquelas do passado, conforme observou Barros (1999).

Segundo Barros e Araújo (1991), no início da década de 80, consolidou-se o esgotamento do processo de industrialização via substituição de importações. A crise da dívida externa levou à interrupção do fluxo de poupança do exterior. A capacidade de poupança do setor público se exauriu e o processo inflacionário alcançou níveis politicamente insustentáveis. Já não haviam justificativas e nem mesmo condições para a manutenção do conjunto de políticas públicas que nortearam o crescimento econômico 
na década de 70. Por essa razão, assistiu-se nos anos 80 a uma sucessão de tentativas de se ajustar a economia brasileira à nova realidade, utilizando instrumentos de política tipicamente voltados para o mercado. No caso da agricultura, foi proposta uma combinação de instrumentos para revigorar o crescimento do setor sem comprometer os objetivos macroeconômicos de controle fiscal e monetário.

De acordo com Ferreira Filho (1997), a análise do desenvolvimento do setor agrícola brasileiro no período, sugere que este foi muito menos afetado pela crise do que o setor industrial, tendo o mesmo apresentado um crescimento praticamente constante ao longo da década, à uma taxa média anual de $2,5 \%$, contra $0,38 \%$ para a indústria, observando-se entretanto, que este crescimento diferencial da agricultura se deu em ambiente econômico aparentemente adverso, com queda dos preços agrícolas frente aos industriais.

Ferreira Filho (1997) salientou que o mecanismo de ajustamento da economia brasileira à crise dos anos 80 gerou as condições para que a agricultura tivesse um desempenho mais favorável que a indústria, em termos agregados, ao afetar mais severamente a demanda pelos produtos industriais, do que os agrícolas. Isto se deu pelo tipo de contração de demanda agregada levado a efeito como forma de gerar divisas, havendo ainda durante a década importante queda nos custos de produção agrícola, ocasionada em parte pela queda nos preços dos principais fatores de produção utilizados pela agricultura.

Deve-se ressaltar que paralelamente à redução dos volumes de recursos transferidos à agricultura neste período, o setor alcançou consideráveis ganhos de produtividade. Segundo Rezende e Buainain (1994), a linha de política econômica adotada nos anos 70 tinha como preocupação central promover o crescimento da economia brasileira a qualquer custo, sem apresentar maiores preocupações com o equilíbrio e sustentabilidade das contas nacionais. Já no início dos anos 80, tornava-se necessária uma alteração na rota da política econômica adotada, a qual teria como consequiência uma redução dos volumes de recursos fornecidos àagricultura, decorrente da crise fiscal e financeira do governo federal, que foi limitando gradualmente sua capacidade de transferir renda. 
Barros (1999) afirma que quando se procura estudar o desempenho da agricultura nos anos 80 e 90, chamam atenção, além dos ganhos de produtividade que ocorreram no setor como um todo, o padrão de evolução da área cultivada, que apresenta um aumento até meados da década de 80 , mas ao se adentrar aos 90, retorna aos mesmos níveis do início dos anos 80.

Outro aspecto ressaltado por Barros (1999), é que o desempenho superior da agricultura frente à indústria no Brasil dos anos 80 se deu em um ambiente de maior exposição do setor agrícola ao mercado internacional, tendo a proporção do valor do produto exportado sobre o valor da produção total, aumentado entre o final dos anos 70 até meados dos 80 .

Em média, o volume anual de crédito rural concedido na década de 90 foi bem menor em relação àqueles concedidos na década de 70 e primeira metade da década de 80, podendo-se concluir que a recuperação da importância da agropecuária no PIB a partir de 1994 ocorreu em uma situação de menor recurso e sem subsídio (entenda-se como juros reais negativos) no crédito rural.

Segundo Goldin e Rezende (1993), na tentativa de compensar a redução do volume de crédito rural na década de 80 , ocorreram modificações na Política de Garantia de Preços Mínimos (PGPM) que permitiram a expansão da produção agropecuária, principalmente na região Centro-Oeste do Brasil, entretanto, na primeira metade da década de 90 as dificuldades financeiras do Tesouro Nacional levaram a uma sensível diminuição na utilização desta política, e na segunda metade da década, o governo brasileiro instituiu novos mecanismos seletivos para executá-la. A partir de 1988, os gastos realizados pelo setor público na agricultura diminuíram sensivelmente, implicando, entre outras coisas, na redução das atividades de extensão rural.

A falta de recursos para executar a PGPM e a dificuldade de manusear e vender os produtos adquiridos levaram o governo, a partir de 1997, a instituir o programa de Prêmio para Escoamento de Produto (PEP), no qual o Governo Federal se compromete a comprar um produto agrícola a seu preço mínimo (via, por exemplo, AGF ou Contratos de Opção de Venda), mas evita estocá-lo, realizando, portanto, um leilão de prêmios para um arrematante adquirir o produto diretamente do produtor. Através deste 
programa o Governo Federal tem sido mais seletivo nos produtos e regiões a serem beneficiadas com a PGPM.

Dentre os programas amplos de desenvolvimento setorial da agricultura realizados pelo governo, foram importantes o Plano Nacional de Desenvolvimento Agroindustrial (PNDA) e o Plano Nacional de Desenvolvimento Rural (PNDR), criados em 1989 para repassar recursos do Banco Mundial a serem investidos em atividades agro-industriais, objetivando proporcionar a modernização deste setor em todo o território nacional.

Em síntese, no período pós-1986 houve menor utilização dos instrumentos de estímulo à expansão da produção agropecuária; entretanto, o que se observou não foi uma redução drástica da participação da agropecuária na composição do Produto Interno Bruto (PIB), passando de 6,84\% em 1994 para 6,32\% em 1999 (CNA/CEPEA-USP, 2003), o que se justifica, em parte, pela melhora dos preços relativos agropecuários / industriais; melhora da relação entre preços recebidos / preços pagos pela agropecuária; e, o aumento da produtividade da agropecuária. Esses três fatores combinaram-se de sorte a manter constante a participação da agropecuária no PIB conforme acima especificado, compensando os efeitos negativos sobre essa participação advindos do crescimento da produtividade do setor não agropecuário.

As transformações na polítca agrícola brasileira tiveram impacto na evolução da área cultivada no país. Até meados dos anos 80 a área de lavouras anuais e perenes seguiu crescendo sistematicamete e, a partir de então, a espansão da produção se deu por incremento de produtividade (Barros, 1999). A expansão de área acima referido envolveu a incorporação da região central do país, através da disseminação de variedades adaptadas à região dos cerrados, bem como do desenvolvimento de tecnologias de adubação e manejo das lavouras. O processo de diversificação regional da produção brasileira fez com que a região Centro-Oeste assumisse relevância crescente na oferta agrícola do país. A evolução da agricultura nos últimos 30 anos no Centro-Oeste consiste no eixo central do desenvolvimento econômico da região. 


\subsection{O Desenvolvimento da região Centro-Oeste no Brasil}

\subsubsection{Histórico}

Monteiro Neto e Gomes (2000) realizaram um estudo a respeito do crescimento econômico do Centro-Oeste brasileiro, o qual mostra que a região apresentou um dos melhores perfis de desempenho econômico quando comparado com as demais regiões brasileiras no período de 1960 a 1996, justificado, de um lado, no fato de sua base produtiva ter se diversificado de maneira muito acelerada, e, de outro, de o crescimento populacional ter contribuído para a ocupação de grandes áreas inóspitas prevalecentes até então.

Constataram que o Centro-Oeste aumentou sua participação no PIB nacional de 2,45\% em 1960 para 7,45\% em 1996. Ao comparar as taxas de crescimento do PIB total da região e de todo o Brasil, ao longo do período considerado, verificaram que enquanto o Produto Interno Bruto do Brasil crescia a uma taxa de 5,2\% ao ano, o da região Centro-Oeste crescia em média 8,3\% ao ano. A Tabela 1 mostra uma desagregação das taxas de crescimento do Centro-Oeste e do Brasil como um todo, em diversos subperíodos específicos, através da qual pode-se verificar que em nenhum dos subperíodos a região Centro-Oeste sofreu um crescimento negativo do PIB. As décadas de 60 e 70, que se caracterizaram por forte crescimento econômico para todo o país foram extremamente positivas para o Centro-Oeste, e mesmo, nos anos 80 (quando o país passou por uma crise forte e desacelerou suas taxas de crescimento), a economia da região se diferenciou do padrão regional de redução de atividade e continuou em um ritmo acelerado de crescimento à taxa de $9,1 \%$ ao ano. Os índices de instabilidade das taxas de crescimento revelaram-se baixos para o Centro-Oeste, indicando, portanto, que o crescimento observado na economia da região ao longo das quatro décadas, além de muito alto, foi também bastante estável. 
Tabela 1. Taxas médias anuais de crescimento e índices e instabilidade do produto interno bruto para diferentes períodos compreendidos entre 1960 e 1996.

\begin{tabular}{lcccc}
\hline \multirow{2}{*}{ Período } & \multicolumn{2}{c}{ Taxa média anual de } & \multicolumn{2}{l}{ Índice de instabilidade } \\
& crescimento do PIB (\%) & & \\
\hline & Brasil & Centro-Oeste & Brasil & $\begin{array}{c}\text { Centro- } \\
\text { Oeste }\end{array}$ \\
\hline $1960 / 96$ & 5,2 & 8,3 & 73 & 57 \\
$1970 / 96$ & 3,8 & 6,7 & 119 & 50 \\
$1980 / 96$ & 2,2 & 5,1 & 140 & 55 \\
Década de 60 & 4,5 & 6,1 & 223 & 407 \\
Década de 70 & 8,5 & 12,1 & 25 & 4 \\
Década de 80 & 3,1 & 9,1 & 192 & 358 \\
1990/96 & 3,1 & 4,0 & 104 & 315 \\
Ajustamento (1960/67) & 3,8 & 5,9 & 412 & 590 \\
Milagre (1968/73) & 11,4 & 15,7 & 4 & 0 \\
Choques do Petróleo (1974/80) & 6,7 & 10,6 & 9 & 4 \\
Crise da Dívida (1981/83) & 1,1 & 0,1 & 511 & 997 \\
Falsa Recuperação (1984/86) & 7,7 & 11,1 & 0 & 10 \\
Hiperinflação Reprimida (1987/93) & 0,01 & 1,0 & 999,7 & 420 \\
Estabilização do Real (1994/96) & 3,6 & 3,5 & 11 & 89 \\
\hline Fonte: Monteiro Neto e Gom & & &
\end{tabular}

Fonte: Monteiro Neto e Gomes (2000)

Outro elemento importante responsável pelo intenso crescimento econômico observado na região Centro-Oeste durante as últimas décadas, além da mudança na composição setorial da atividade produtiva, como dito anteriormente, é a atuação do Estado na destinação direta de grandes volumes de recursos para a criação de infraestrutura econômica e social, e na expansão de gastos correntes, que influenciam indiretamente o crescimento ao expandir a demanda agregada e, portanto, induzir o investimento privado.

De acordo com Gomes e Vergolino (1997), ao distribuir suas despesas sem levar em conta sua origem geográfica, o governo federal está promovendo redistribuição de renda, o que se constitui em uma maneira de contribuir, positiva ou negativamente, para o desenvolvimento de uma região. Quando ocorre de o governo realizar despesas em excesso às receitas obtidas numa região, este está transferindo renda de outras 
regiões do país para a região em evidência, que foi o que ocorreu com o Centro-Oeste nas últimas quatro décadas.

O setor público tem tido o papel de estimulador do setor privado ao dispor de linhas de crédito oficiais para o financiamento da produção, como BNDES (desembolsos correntes), Banco do Brasil (crédito agrícola exclusivamente para investimento) e o Fundo Constitucional para o Desenvolvimento do Centro-Oeste/FCO. A forma pela qual os incentivos são canalizados para o setor privado é a dos financiamentos concedidos à atividades industriais e agropecuárias na região.

A construção de Brasília, nova capital federal, no início dos anos 60, é uma das interpretações para o comportamento do setor público na geração de riqueza no CentroOeste, uma vez que todos os assuntos burocráticos do Brasil foram sendo transferidos do Rio de Janeiro para Brasília, em conjunto com um contingente relevante do funcionalismo público federal.

Embora o intenso crescimento econômico verificado no Centro-Oeste brasileiro seja atribuído em grande parte à mudança na composição setorial da atividade produtiva, que era essencialmente ligada ao setor agropecuário, o qual foi paulatinamente tendo sua participação substituída pela indústria e pelo setor de serviços, não se deve, entretanto, minimizar a importância da agropecuária para a economia da região, pois conforme salientaram Galindo e Santos (1995), ainda que o PIB agropecuário represente a menor parcela do produto regional em termos relativos, a participação da agropecuária no Centro-Oeste reveste-se de significativa importância, uma vez que foi através deste setor que se deu a ocupação do espaço regional e uma maior integração comercial com outras regiões, sobretudo com o Sul e Sudeste. Seu desenvolvimento possibilitou também o surgimento do setor industrial no início dos anos 30 e seu posterior impulso a partir dos anos 80, o que provocou a expansão urbana de alguns centros já tradicionais e o aparecimento de novos aglomerados populacionais.

Esforços consideráveis para o desenvolvimento da produção de grãos na região dos cerrados, desde a década de 70 , têm resultado no aumento da participação do Centro-Oeste na produção brasileira de grãos, que de 10,7\% em 1973, saltou para 25,3\% 
em 1997, conforme salientaram Resende e Helfand ${ }^{3}$ baseados em dados do IBGE. Caracterizada por alta capitalização e produtividade do campo, tal produção conduziu a uma transformação tecnológica muito expressiva para a região, com a atração de empresas agroindustriais de peso nacional.

Durante a década de 80 , a taxa de crescimento da área total colhida de grãos no Brasil foi bastante reduzida, após um período de rápida expansão nos anos 70 . Contrastando com a área colhida, a qual no final da década de 90 foi essencialmente a mesma do começo dos anos 80, a quantidade total produzida de grãos tem crescido sistematicamente, cuja consequiência tem sido um aumento significativo do rendimento físico agregado durante todo o período, principalmente na década de 90. Segundo Helfand e Resende (2000), é provável que a abertura da economia e a redução do papel do estado, por meio das políticas de preços mínimos e crédito rural, tenham levado à uma reorganização da geografia da produção, tornando-a mais consistente æ̀̀ vantagens comparativas regionais.

A partir da Tabela 2 pode ser feita uma análise regional em relação à evolução da área colhida e da produção de grãos. Em contraste com as demais regiões, a área colhida no Centro-Oeste apresentou acentuado crescimento durante o período considerado. A produção de grãos também apresentou um crescimento de forma mais rápida nesta região do que nas outras, e como resultado desse crescimento, a produtividade da terra cresceu durante todo o período, atingindo níveis sem precedentes nos anos 90. Não se pode deixar de comentar a respeito da grande queda ocorrida na produção de grãos em 1990, nas regiões Sudeste e Centro-Oeste, e em 1991, na região Sul, gerando uma crise na produção brasileira de grãos nestes dois anos, a qual não se deveu apenas a mudanças nas políticas agrícolas e comerciais, como usualmente se acredita, mas também a dois anos consecutivos de condições climáticas desfavoráveis, conforme salientaram Helfand e Resende (2000).

\footnotetext{
${ }^{3}$ REZENDE, G.C.; HELFAND, S.M. Estruturas regionais de produção, consumo e preços agrícolas: os casos do milho, aves e suínos. Brasília: Instituto de Pesquisa Econômica Aplicada, 1993. (Versão preliminar para discussão)
} 
Tabela 2. Área e produção de grãos por região do Brasil (em milhões de ha e toneladas).

\begin{tabular}{lllllllllll}
\hline \multirow{2}{*}{ Ano } & Norte & \multicolumn{3}{c}{ Nordeste } & \multicolumn{2}{c}{ Sudeste } & \multicolumn{2}{c}{ Sul } & \multicolumn{2}{c}{ Centro-Oeste } \\
\cline { 2 - 10 } & Área & Produção & Área & Produção & Área & Produção & Área & Produção & Área & Produção \\
\hline 1973 & 0,2 & 0,2 & 5,6 & 3,8 & 6,3 & 8,2 & 11,3 & 16,7 & 2,6 & 3,5 \\
1975 & 0,3 & 0,4 & 5,9 & 3,8 & 6,4 & 8,0 & 14,8 & 23,1 & 3,3 & 4,2 \\
1980 & 0,5 & 0,7 & 5,8 & 3,0 & 6,4 & 9,9 & 17,6 & 30,5 & 5,2 & 7,5 \\
1985 & 0,7 & 0,8 & 6,9 & 3,9 & 6,6 & 11,5 & 16,5 & 31,8 & 6,2 & 10,8 \\
1990 & 0,8 & 0,9 & 5,9 & 2,5 & 6,2 & 9,4 & 15,8 & 31,5 & 6,9 & 11,4 \\
1995 & 1,2 & 1,7 & 7,9 & 6,6 & 5,6 & 12,5 & 14,6 & 39,5 & 7,8 & 18,8 \\
1999 & 1,5 & 2,3 & 5,8 & 6,2 & 4,9 & 11,9 & 14,1 & 37,1 & 8,5 & 24,0 \\
\hline
\end{tabular}

Fonte: IBGE (1970, 1999)

Os autores afirmaram também que o Centro-Oeste foi a região mais dinâmica do país, apresentando um crescimento de $10 \%$ em sua área colhida de grãos e de $50 \%$ em sua produção de grãos na década de 90 quando em comparação com a década de 80. Grande parte desse dinamismo se deve àsoja, cuja área colhida no Centro-Oeste, como porcentagem da área dos seis cultivos principais, aumentou de uma média de $36 \%$ na década de 80 para 54\% na década de 90, substituindo em larga escala o arroz. Apesar da interrupção ocorrida no crescimento da área colhida de milho no início dos anos 90, esta cultura teve um aumento em sua participação na área total com grãos de $21 \%$ nos anos 80 para $25 \%$ nos anos 90 . Todos os cultivos experimentaram ganhos de produtividade na década de 90, relativamente à década anterior. Além disso, afirmaram também que boa parte do aumento da produção de milho no Centro-Oeste no período de 1994/97 se deu na forma de milho segunda safra, que representou 15\% do total em 1994/96 e 25\% do total em 1997. Como o milho segunda safra no Centro-Oeste se deve àcrescente adoção do plantio direto na cultura da soja (uso do milho como cobertura do solo no inverno) e à necessidade agronômica de rotação com a mesma (a qual estimula, também, o milho de primeira safra), pode-se perceber a grande importância que a cultura da soja tem no desenvolvimento agrícola da região Centro-Oeste.

No que diz respeito aos fatores que mais contribuíram para o crescimento da produção de grãos na região Centro-Oeste, destacam-se os incentivos fiscais disponibilizados para a abertura de novas áreas de produção agrícola, assim como para a aquisição de máquinas e construção de silos e armazéns; estabelecimento de agroindústrias na região, estimuladas pelos mesmos incentivos fiscais disponibilizados para a ampliação da fronteira agrícola; baixo valor da terra na região, comparado ao da 
região Sul, nas décadas de 1960/70/80; topografia favorável à mecanização; boas condições físicas dos solos da região; melhorias no sistema de transporte da produção regional, com o estabelecimento de corredores de exportação, utilizando articuladamente rodovias, ferrovias e hidrovias; elevado nível econômico e tecnológico dos produtores do Brasil central; regime pluviométrico favorável aos cultivos de verão; dentre outros.

O Centro-Oeste apresenta vantagem em termos de ganhos relativos de aptidão agrícola com a adoção de alta tecnologia, o que se deve ao fato de suas terras serem planas, fazendo com que a região adquira vantagem comparativa nas atividades mais beneficiadas (em termos de redução do custo de produção) pela mecanização, normalmente associada àpresença de economias de escala e poupadora de mão-de-obra, fator escasso no Centro-Oeste.

Segundo Diniz (1993) e Guimarães Neto (1997), a expansão agrícola da região Centro-Oeste teve um papel relevante na desconcentração espacial da atividade econômica do país, sobretudo da indústria.

O dinamismo da região pode ser expresso pelo Estado do Mato Grosso, o qual detinha parcela diminuta da produção agrícola quando criado (em 1977), e hoje, 26 anos depois, responde por cerca de $27 \%$ da produção nacional de soja.

\subsubsection{O estado do Mato Grosso}

Silva, A. (1982) afirma que de acordo com o Tratado de Tordesilhas, o atual estado de Mato Grosso, como quase todo o Centro-Oeste e a Região Norte, pertencia à Espanha. Por muito tempo, sua exploração se limitou a esporádicas expedições de aventureiros e à atuação de missionários jesuítas espanhóis. A ocupação do estado guarda uma semelhança muito grande com a ocupação territorial brasileira, a qual foi efetuada aos saltos, com núcleos de povoação, surgidos em função de episódios históricos marcantes, como por exemplo, as Bandeiras no séc. XVII, expedições organizadas com o objetivo de escravizar índios. Tais expedições tiveram seus propósitos desviados em função da descoberta do ouro no séc. XVIII, que por sua vez

atraiu grande contingente populacional para aquelas áreas, que acabaram se 
transformando em vilas e cidades. A região foi incorporada ao Brasil em 1750, pelo Tratado de Madri.

Além disso, no século XIX, com o declínio da mineração, o empobrecimento e o isolamento da província se tornaram inevitáveis. Alguma atividade agrícola e mercantil de subsistência sobreviveu nos campos mais férteis do sul. O único meio de transporte até a capital era o navio, numa viagem pelo rio Paraguai. Na República, esse isolamento foi sendo vencido com a ampliação da rede telegráfica pelo marechal Cândido Rondon, a navegação a vapor e a abertura de algumas estradas precárias. Esse avanço em infra-estrutura atrai seringueiros, criadores de gado, exploradores de madeira e de erva-mate para a região.

O estado do Mato Grosso sempre foi muito esquecido pelo Governo Central, tendo recebido atenção do Governo Federal somente durante a guerra do Paraguai, ocasião na qual nasceram cidades típicas das regiões fronteiriças como Jardim, Miranda, Forte Coimbra e Porto Murtinho, em função da necessidade de se garantir a segurança nacional.

Como todo o Centro-Oeste, o estado de Mato Grosso beneficiou-se da política de interiorização do desenvolvimento dos anos 40 e 50 e da política de integração nacional dos anos 70. A primeira foi baseada principalmente na construção de Brasília e a segunda, nos incentivos aos grandes projetos agropecuários e de extrativismo, além dos investimentos em infra-estrutura, estradas e hidrelétricas. Com esses recursos, o estado prospera e atrai dezenas de milhares de imigrantes. De acordo com dados do IBGE, sua população saltou de 430 mil para 1,6 milhão de habitantes entre 1940 e 1970.

Novo surto de desenvolvimento econômico surge em função da construção da estrada de ferro Noroeste do Brasil, ligando São Paulo a Corumbá na fronteira com a Bolívia, registrando uma mudança no comportamento do transporte, que até então era feito exclusivamente pelos rios, uma vez que as estradas eram praticamente intransitáveis, o que veio a modificar os contornos demográficos da ocupação territorial do estado, ensejando a criação de cidades como Campo Grande e Três Lagoas (Silva, 1982). 


\subsubsection{A divisão do estado do Mato Grosso}

O movimento divisionista vinha de longa data e foi se fortalecendo cada vez mais. A primeira tentativa de se criar um novo estado ocorreu em 1892, por iniciativa de alguns revolucionários sob as ordens do coronel Barbosa, que justificavam a criação do novo estado em decorrência da dificuldade em desenvolver a região diante da grande extensão e diversidade e das diferenças econômicas que geravam uma rivalidade entre as duas regiões de Mato Grosso: o norte e o sul. A região sul sentia-se prejudicada, pois se considerava a responsável pela maior parte da renda gerada pelo estado e seus habitantes, os sulinos entendiam que o norte ficava com a maior parte dos benefícios.

Finalmente, em 11 de outubro de 1977 o presidente Ernesto Geisel assinava a lei complementar no 31, criando o Estado de Mato Grosso do Sul, pelo desmembramento de área do Estado de Mato Grosso (Weingartner, 2003). Nesse dia, de acordo com dados do censo demográfico do IBGE para 1970, o antigo estado de Mato Grosso tinha cerca de 2.300.000 habitantes, distribuídos por 93 municípios. Segundo estimativas baseadas no censo de 1970, com o desmembramento, o novo Estado Mato Grosso do Sul, passou a contar com uma população de 1.400.000 habitantes, distribuídos em 55 municípios, numa área de cerca de $350.000 \mathrm{~km}^{2}$. Mato Grosso remanescente ficou com uma população de cerca de 900.000 habitantes, distribuídos em $903.357,908 \mathrm{Km}^{2}$, dentro de 38 municípios, que se multiplicaram em decorrência da explosão agrícola, a qual será comentada posteriormente. Atualmente, de acordo com as estatísticas da Secretaria de Planejamento do estado, o Mato Grosso conta com 139 municípios.

\subsubsection{O estado do Mato Grosso após a divisão}

Mesmo após o desmembramento, o Mato Grosso ainda é a terceira Unidade Federativa em superfície, com uma área de $903.357,908 \mathrm{~km}^{2}$, perdendo apenas para os estados do Amazonas e Pará.

Presenciou um significativo crescimento populacional desde a década de 80 até o período atual, tendo sido um importante pólo de imigração nos anos 90. A Tabela 3 
mostra que a população total do estado, entre 1980 e 2000, cresceu em aproximadamente $120 \%$, sendo que no período ocorreu um aumento da proporção da população urbana em relação àrural. Em 1980, a população urbana representava 58\% do total e a rural $42 \%$. Já em 2000, a população urbana passou a representar $80 \%$ do total e a rural 20\% apenas.

Tabela 3. População do estado do Mato Grosso (habitantes).

\begin{tabular}{lcccc}
\hline \multicolumn{5}{c}{ Ano } \\
\hline Situação & 1980 & 1991 & 1996 & 2000 \\
Urbana & 655.141 & 1.485 .110 & 1.695 .548 & 1.987 .726 \\
Rural & 483.777 & 542.121 & 540.284 & 516.627 \\
Total & 1.138 .918 & 2.027 .231 & 2.235 .832 & 2.504 .353 \\
\hline
\end{tabular}

Fonte: IBGE (2000)

Baseado em informações divulgadas pelo IBGE, calcula-se que entre $1991 \mathrm{e}$ 2000 o Mato Grosso apresentou um crescimento demográfico de 2,4\% ao ano. Em 2000 apresentou a menor densidade demográfica da região Centro-Oeste, com média de 2,8 habitantes por $\mathrm{km}^{2}$. A população se distribui de forma desigual. Há desertos demográficos ao norte, onde a densidade gira em torno de 1,8 habitante por $\mathrm{km}^{2}$, e áreas urbanas como Cuiabá (102 habitantes por km²) e Várzea Grande (180 habitantes por $\mathrm{km}^{2}$ ). O maior crescimento populacional é registrado nas áreas onde a expansão da produção de grãos em escala comercial é recente, como Sorriso (9\% ao ano) e Sinop $(8,6 \%)$. Essas cidades recebem grande número de migrantes vindos, sobretudo, da Região Norte.

No que diz respeito à educação, a Tabela 4 mostra que 75,79\% da população acima de 5 anos de idade, no Mato Grosso, era alfabetizada em 1991, sendo que em 2000 a população alfabetizada já representava $85,05 \%$ do total do estado. 
Tabela 4. População residente no Mato Grosso (número de pessoas com cinco anos ou mais).

\begin{tabular}{lcc}
\hline & \multicolumn{2}{c}{ Ano } \\
\hline Alfabetizados & 1991 & 2000 \\
Analfabetos & 1.343 .694 & 1.913 .591 \\
Total & 429.174 & 336.397 \\
\hline
\end{tabular}

Fonte: IBGE (2000)

Quanto aos estabelecimentos de saúde no estado do Mato Grosso, a Tabela 5 mostra que, de 1980 para 2002, estes apresentaram um aumento em número de unidades na ordem de $540 \%$, ou seja, cresceram em mais de seis vezes, enquanto que para o Brasil como um todo, esta proporção se deu na ordem de $254 \%$, ou seja, cresceram pouco mais que três vezes.

Tabela 5. Estabelecimentos de saúde no Brasil, Centro-Oeste e Mato Grosso 1980/

\begin{tabular}{lccc}
2002. & & & \\
\hline Ano & Brasil & Centro-Oeste & Mato Grosso \\
\hline 1980 & 18.489 & 1.185 & 210 \\
1985 & 28.972 & 1.878 & 337 \\
1990 & 35.701 & 2.195 & 599 \\
2002 & 65.343 & 5.125 & 1.346 \\
\hline
\end{tabular}

Fonte: IBGE (2003)

\subsubsection{Características agropecuárias do estado do Mato Grosso ${ }^{4}$}

O Estado de Mato Grosso, situado na região Centro-Oeste, possui a maior parte de suas terras dentro dos limites da Amazônia Legal. Devido a uma política de

\footnotetext{
${ }^{4}$ Boa parte baseada em um levantamento primário de informações realizado pelo pesquisador Dr. Sérgio De Zen, encontradas em De Zen (2002)
} 
incentivos fiscais a partir da década de 70, houve a implantação de grandes projetos agropecuários responsáveis por algumas transformações na organização da produção do estado, onde a agricultura de subsistência e a pecuária extensiva estão cedendo espaço para uma agricultura moderna e uma pecuária especializada.

De acordo com os dados da Tabela 6, revela-se substancial mudança na estrutura da distribuição de estabelecimentos agropecuários desde 1970. Neste ano a mesma mostrou-se concentrada, com $82,2 \%$ do número de estabelecimentos tendo acesso a apenas 3,3\% da área total em estabelecimentos, no extremo das unidades com menos de 100 ha; e, no outro extremo, o de unidades com mais de 1000 ha, apenas 4,9\% dos estabelecimentos controlavam 86,4\% da área total. Em 1995, as disparidades de distribuição da terra mostram-se menos agudas, embora permanecem substanciais. Assim, no extremo das pequenas unidades, 59,5\% dos estabelecimentos tiveram acesso a $3,3 \%$ da área total, enquanto no extremo das grandes unidades, $10,2 \%$ dos estabelecimentos controlavam $82,2 \%$ da área total.

Tabela 6. Proporção do número e da área dos estabelecimentos, por grupos de área total - Mato Grosso (1970/1995).

\begin{tabular}{|c|c|c|c|c|}
\hline \multirow[t]{2}{*}{$\begin{array}{c}\text { Grupos de área total } \\
\text { (ha) }\end{array}$} & \multicolumn{2}{|c|}{$\begin{array}{c}\text { Proporção do número dos } \\
\text { estabelecimentos } \\
(\%)\end{array}$} & \multicolumn{2}{|c|}{$\begin{array}{c}\text { Proporção da área dos } \\
\text { estabelecimentos } \\
(\%)\end{array}$} \\
\hline & 1970 & 1995 & 1970 & 1995 \\
\hline Menos de 10 & 51,7 & 12,4 & 0,6 & 0,1 \\
\hline 10 a menos de 100 & 30,5 & 47,1 & 2,7 & 3,2 \\
\hline 100 a menos de 1000 & 12,9 & 30,3 & 10,3 & 14,5 \\
\hline 1000 a menos de 10000 & 4,1 & 9,2 & 31,0 & 40,8 \\
\hline 10000 e mais & 0,8 & 1,0 & 55,4 & 41,4 \\
\hline Total & 100,0 & 100,0 & 100,0 & 100,0 \\
\hline
\end{tabular}

Fonte: IBGE (1970, 1995)

Segundo informações do Censo Agropecuário de 1995/1996, os dados de uso da terra refletem o processo de vigorosa ocupação e abertura das terras associado à expansão da fronteira agrícola no estado. A Tabela 7 mostra que entre 1985 e 1995 houve um modesto aumento no número de estabelecimentos, de 77,9 mil para 78,8 mil unidades, mas um forte incremento na área total dos estabelecimentos, que passou de 
37,8 milhões para 49,8 milhões de hectares no período considerado. A área total dos estabelecimentos no Mato Grosso, captada pelos Censos de 1995/96, compreendeu quase $55 \%$ da área territorial do estado (90,68 milhões de ha). A proporção da área total dos estabelecimentos que havia sido aberta (soma das áreas em lavouras, em pastagens plantadas, em matas plantadas, terras em descanso e produtivas não utilizadas) foi de 40,6\%, ou seja, nesse ano, 59,4\% da área em estabelecimentos não haviam sido significativamente alteradas. Deve-se ressaltar que a área aberta apresentou o incremento de 8,7 milhões de hectares durante o período, tendo sido o principal responsável por este aumento o item pastagens plantadas, que registrou um incremento de mais de 8,5 milhões de hectares. As áreas em lavouras apresentaram um incremento de 814,3 mil hectares (de 2,1 milhões para 2,9 milhões de ha) e o único item da área aberta a sofrer redução foi o de terras produtivas, mas não usadas.

Tabela 7. Dados de uso da terra dos censos agropecuários - Mato Grosso - 1985/1996.

Categorias 1985

\begin{tabular}{lcc}
\hline Número de estabelecimentos & 77.921 & 78.762 \\
Área em estabelecimentos & 37.835 .653 & 49.839 .631 \\
Área aberta & 11.477 .212 & 20.214 .382 \\
Área em lavouras & 2.129 .443 & 2.943 .709 \\
Pastagens plantadas & 6.719 .064 & 15.262 .456 \\
Matas plantadas & 26.171 & 67.751 \\
Área em descanso & 426.100 & 494.418 \\
Área produtiva, mas não usada & 2.176 .434 & 1.446 .048 \\
Pastagens naturais & 9.685 .306 & 6.189 .563 \\
Matas naturais & 14.126 .813 & 21.474 .009 \\
Terras inaproveitáveis & 2.546 .322 & 1.961 .677 \\
\hline
\end{tabular}

Fonte: IBGE $(1995,1996)$

\subsubsection{Pecuária}

A pecuária foi introduzida no sul do Mato Grosso, no séc XVI, pelos espanhóis, sendo que a partir do século XIX tornou-se uma das principais atividades econômicas da região. O sistema de criação de gado adotado pelos fazendeiros e que predomina há 
muito tempo é o extensivo. A adoção desse sistema propicia a criação de grandes latifúndios.

A pecuária extensiva é a atividade mais antiga do estado. Apesar deste aspecto tradicional, a pecuária intensiva vem ganhando espaço nos últimos anos. No passado, o fator predominante da atividade pecuária era o baixo nível tecnológico e o uso de grandes extensões de terra. Na moderna pecuária, duas formas de trato cultural têm sido comuns: o uso de pastagens cultivadas em áreas de descanso de culturas anuais e o uso de técnicas que minimizam os efeitos dos meses de seca.

Seu rebanho bovino cresceu $388,85 \%$, ou seja, mais do que quadruplicou, entre 1978 e 2000, ultrapassando 18 milhões de cabeças, concentrando-se no norte e no sudeste do estado. A Tabela 8 mostra que o período entre 1990 e 1995 foi aquele em que o rebanho bovino apresentou maior crescimento, em torno de $54 \%$.

Tabela 8. Rebanho bovino no Mato Grosso (número de cabeças).

\begin{tabular}{ccc}
\hline Ano & Bovinos & $\begin{array}{c}\text { Crescimento em relação ao período } \\
\text { anterior (\%) }\end{array}$ \\
\hline 1978 & 3.888 .000 & - \\
1980 & 5.249 .000 & 35,01 \\
1985 & 6.507 .632 & 23,98 \\
1990 & 9.041 .258 & 38,93 \\
1995 & 13.917 .301 & 53,93 \\
2000 & 18.812 .381 & 35,17 \\
\hline
\end{tabular}

Fonte: Mato Grosso (2001)

Como pode ser observado na Tabela 9, no ano de 2000, 25,88\% do rebanho bovino do MT estavam concentrados em dez municípios, dentre os 139 existentes. 
Tabela 9. População bovina nos dez municípios com maior rebanho no estado do Mato Grosso - Nov/2000.

\begin{tabular}{lcc}
\hline Municípios & Posição & População Bovina (n cabeças) \\
\hline Juara & $1^{\mathbf{o}}$ & 720.717 \\
Cáceres & $2^{\mathbf{o}}$ & 636.517 \\
Pontes e Lacerda & $3^{\mathbf{o}}$ & 536.457 \\
Alta Floresta & $4^{\mathbf{o}}$ & 519.887 \\
Vila B. S. Trindade & $5^{\mathbf{o}}$ & 515.000 \\
S. Ant. do Leverger & $6^{\mathbf{o}}$ & 411.000 \\
Juina & $7^{\mathbf{o}}$ & 410.863 \\
Água Boa & $8^{\mathbf{o}}$ & 380.866 \\
São José do Xingu & $9^{\mathbf{o}}$ & 369.232 \\
Barra do Garças & $1^{\mathbf{o}}$ & 368.438 \\
Total & & 4.868 .977 \\
Total do estado & & 18.812 .381 \\
\hline
\end{tabular}

Fonte: Mato Grosso (2001)

O incentivo do governo para esta atividade, via BNDES, se dá pelo financiamento de novos frigoríficos ou reestruturação de antigos.

A importância da pecuária está na capacidade de representar uma expressiva reserva de valor, pois a comercialização dos animais ocorre durante quase todo o ano.

\subsubsection{Agricultura}

Mesmo diante da importância e do desenvolvimento da pecuária no estado, nota-se que esta atividade foi sendo substituída pela agricultura no decorrer da década de 90, principalmente pelos cultivos de soja e algodão.

As principais culturas de Mato Grosso, atualmente, são arroz, algodão, milho e soja, que em 1980, de acordo com a Tabela 10, ocupavam 1.055.033 ha das áreas de lavoura do estado, e em 2002 passaram a ocupar 5.311.112 ha, com perspectivas de 
atingir os 5.615.054 ha em 2003, o que significa dizer que de 88,62\% em 1980, passaram a ocupar 95,24\% destas áreas em 2002, com perspectivas de ocuparem 95,34\% em 2003, como pode ser observado na Tabela 11. Observa-se também que a soja, isoladamente, ocupava $68,54 \%$ da área total de lavouras em 2002, com perspectivas de ocupar 71,37\% em 2003. Já o arroz, tradicional lavoura do estado, encontra-se em franca redução de área pela falta de capacidade do arroz de sequeiro em competir tanto com o arroz irrigado do Rio Grande do Sul, quanto com o arroz importado.

Tabela 10. Áreas cultivadas com as principais lavouras no Mato Grosso (ha).

\begin{tabular}{ccccccc}
\hline Ano & Algodão & Arroz & Milho & Soja & Outras & Total \\
\hline 1980 & 4.480 & 896.513 & 83.609 & 70.731 & 135.441 & 1.190 .474 \\
1985 & 16.945 & 406.589 & 242.913 & 795.438 & 198.751 & 1.660 .636 \\
1990 & 43.422 & 355.210 & 270.283 & 1.527 .754 & 232.711 & 2.429 .380 \\
1995 & 69.390 & 417.074 & 439.390 & 2.322 .825 & 180.372 & 3.429 .051 \\
2000 & 257.762 & 698.518 & 540.479 & 2.906 .448 & 229.062 & 4.632 .269 \\
2001 & 412.315 & 450.413 & 536.420 & 3.121 .353 & 271.692 & 4.792 .193 \\
2002 & 328.029 & 440.229 & 720.993 & 3.821 .861 & 265.294 & 5.576 .406 \\
2003 & 312.498 & 372.856 & 726.287 & 4.203 .413 & 274.187 & 5.889 .241 \\
\hline
\end{tabular}

Fonte: IBGE (2003)

Tabela 11. Participação das culturas em áreas cultivadas no Mato Grosso (\%).

\begin{tabular}{lcccccc}
\hline Ano & Algodão & Arroz & Milho & Soja & Outras & Total \\
\hline 1980 & 0,38 & 75,31 & 7,02 & 5,92 & 11,38 & 100 \\
1985 & 1,02 & 24,48 & 14,63 & 47,90 & 11,97 & 100 \\
1990 & 1,79 & 14,62 & 11,13 & 62,89 & 9,58 & 100 \\
1995 & 2,02 & 12,16 & 12,81 & 67,74 & 5,26 & 100 \\
2000 & 5,56 & 15,08 & 11,67 & 62,74 & 4,94 & 100 \\
2001 & 8,60 & 9,40 & 11,19 & 65,13 & 5,67 & 100 \\
2002 & 5,88 & 7,89 & 12,93 & 68,54 & 4,76 & 100 \\
2003 & 5,31 & 6,33 & 12,33 & 71,37 & 4,66 & 100 \\
\hline
\end{tabular}

Fonte: IBGE (2003)

Mais de 20 anos após a formação de dois estados, o Mato Grosso, que ficou com a região menos rica, apresenta crescimento expressivo. A principal força econômica 
está na agricultura, cujo crescimento é demonstrado por recordes na produção de soja e de algodão. O Mato Grosso é o maior produtor nacional de soja e algodão, tendo também a maior produtividade quando comparado aos demais estados brasileiros, sendo que para ambos os produtos, a eficiência do sistema de produção faz com que os custos de frete não inviabilizem estas atividades. A Tabela 12 mostra que os volumes de produção de algodão e soja, de 1980 para 2002, passaram de 4.914 t para 1.141 .179 t e de 117.143 t para $11.696 .726 \mathrm{t}$, respectivamente.

Tabela 12. Produção das principais culturas no Mato Grosso (t).

\begin{tabular}{lcccc}
\hline & Algodão & Arroz & Milho & Soja \\
\hline 1980 & 4.914 & 1.175 .041 & 142.572 & 117.173 \\
1985 & 21.837 & 521.776 & 410.500 & 1.656 .039 \\
1990 & 57.634 & 420.722 & 618.973 & 3.064 .715 \\
1995 & 87.458 & 762.327 & 1.226 .157 & 5.491 .426 \\
2000 & 1.002 .837 & 1.851 .517 & 1.421 .613 & 8.774 .471 \\
2001 & 1.525 .376 & 1.151 .816 & 1.743 .043 & 9.533 .286 \\
2002 & 1.141 .179 & 1.198 .558 & 2.314 .410 & 11.696 .726 \\
2003 & 1.135 .869 & 1.052 .087 & 2.336 .832 & 13.137 .356 \\
\hline
\end{tabular}

Fonte: IBGE (2003)

A Tabela 13 mostra que a produtividade média da soja passou de 1,66 t / ha em 1980 para 3,06 t / ha em 2002, com perspectivas de atingir 3,13 t / ha em 2003. Já no caso do algodão, sua produtividade média passou de 1,10 para 3,48 no mesmo período, e tem previsão de atingir 3,63 t / ha em 2003. 
Tabela 13. Produtividade das principais culturas no Mato Grosso ( $/$ / ha).

\begin{tabular}{lcccc}
\hline & Algodão & Arroz & Milho & Soja \\
\hline 1980 & 1,10 & 1,31 & 1,71 & 1,66 \\
1985 & 1,29 & 1,28 & 1,69 & 2,08 \\
1990 & 1,33 & 1,18 & 2,29 & 2,01 \\
1995 & 1,26 & 1,83 & 2,79 & 2,36 \\
2000 & 3,89 & 2,65 & 2,63 & 3,02 \\
2001 & 3,70 & 2,56 & 3,25 & 3,05 \\
2002 & 3,48 & 2,72 & 3,21 & 3,06 \\
2003 & 3,63 & 2,82 & 3,22 & 3,13 \\
\hline
\end{tabular}

Fonte: IBGE (2003)

Conforme registrado na Tabela 14, na safra 2001/2002 a produção de soja do estado respondeu por 11,69 milhões de toneladas, com previsão de atingir 14,04 milhões de toneladas na safra de 2002/2003. Ao longo da década de 90, a participação da produção de soja do MT sobre a do Brasil passou de 18,3\% para 26,8\%.

Tabela 14. Evolução da produção de soja no MT e no Brasil em milhões de toneladas.

\begin{tabular}{llll}
\hline Safra & MT & Brasil & Participação (\%) \\
\hline $92 / 93$ & 4,119 & 22,558 & 18,3 \\
$93 / 94$ & 5,320 & 24,912 & 21,4 \\
$94 / 95$ & 5,491 & 25,651 & 21,4 \\
$95 / 96$ & 5,033 & 23,155 & 21,7 \\
$96 / 97$ & 6,061 & 26,391 & 23,0 \\
$97 / 98$ & 7,228 & 31,307 & 23,1 \\
$98 / 99$ & 7,469 & 30,915 & 24,2 \\
$99 / 00$ & 8,775 & 32,754 & 26,8 \\
$00 / 01$ & 9,533 & 37,720 & 25,3 \\
$01 / 02$ & 11,697 & 42,020 & 27,8 \\
$02 / 03$ & 14,040 & 50,965 & 27,5
\end{tabular}

Fonte: IBGE (2003) 
Além de verficar a evolução da produção e área cultivada com as grandes culturas no estado do Mato Grosso, seria também interessante comparar a participação do Mato Grosso sobre a produção nacional com a participação de outros estados na produção nacional de algumas culturas. De acordo com o Censo Agropecuário 1995/96, divulgado pelo IBGE, a produção nacional de algodão neste período foi de 814.188toneladas, a de arroz de 8.047.895 toneladas, a de milho de 25.510.505 toneladas e a de soja de 21.563 .768 toneladas. A Tabela 15 mostra a participação de alguns estados na produção nacional destas culturas, conforme descrito no Censo Agropecuário 1995/1996.

Deve-se ressaltar que, de 1995/96 para 2001/02, a produção de soja no Mato Grosso cresceu em aproximadamente $113 \%$, ou seja, mais do que dobrou, e sua participação sobre a produção nacional passou de $21,7 \%$ para $27,8 \%$, conforme registrado anteriormente na Tabela 14.

Tabela 15. Participação dos estados na produção de algumas lavouras no Brasil (em \%) em 1995/1996.

\begin{tabular}{lcccc}
\hline & Algodão & Arroz & Milho & Soja \\
\hline Mato Grosso & 5,71 & 7,32 & 4,74 & 21,70 \\
Minas Gerais & 5,73 & 2,08 & 12,00 & 4,01 \\
São Paulo & 18,54 & 0,72 & 10,70 & 3,94 \\
Paraná & $32, .85$ & 1,77 & 25,86 & 28,04 \\
Rio Grande do Sul & 0,00 & 57,72 & 11,31 & 19,72 \\
Mato Grosso do Sul & 9,42 & 2,02 & 5,21 & 8,33 \\
Goiás & 17,96 & 2,50 & 11,65 & 9,09 \\
Outros & 9,78 & 25,88 & 18,52 & 5,17 \\
\hline
\end{tabular}

Fonte: IBGE (1995/1996)

Com relação à compra dos insumos, a cotação de produtos é muito comum entre os produtores do Mato Grosso. De acordo com De Zen (2002), numa pesquisa realizada pelo CEPEA-ESALQ/USP, a grande maioria dos produtores faz a cotação e planejamento da compra de insumos, sendo esta última realizada principalmente de forma direta com o fabricante.

No que diz respeito àvenda dos produtos, a estru tura comercial do estado segue algumas características típicas de cada produto. Para o caso da soja, esta tem 
significativa dependência das grandes tradings, como Cargill, ADM e Ceval. Estas empresas recebem tal produto de duas formas distintas: a compra ou a compra antecipada, via CPR de gaveta (CPRs que não passam pelo aval do Banco do Brasil).

As relações comerciais no mercado de soja são muito pautadas pela dependência que o produtor tem em relação ao crédito de custeio. As empresas que dominam a aquisição da soja são aquelas que possuem estruturas capazes de financiar os produtores.

O acelerado crescimento da produção no Mato Grosso não permite fazer uma distinção entre a parcela que é entregue àindústria daquela que passa por intermediários. As empresas de menor porte e algumas cooperativas também perderam espaço. As estruturas foram arrendadas ou vendidas à grandes empresas. Alguns produtores de grande porte, como os casos específicos dos grupos Maggi e Sachetti, procuram alternativas àcomercializ ação da produção.

O grupo Maggi investiu em uma rota de escoamento da produção pelos rios Madeira e Amazonas. Construiu um terminal portuário próprio, viabilizando uma nova rota de saída e permitindo a exportação direta.

O grupo Sachetti partiu para a comercialização direta dos produtos através de uma corretora própria. O grupo criou uma corretora em Cuiabá e atua na comercialização da própria produção, além da prestação de serviços a terceiros.

O desenvolvimento da agroindústria dentro do estado, além de trazer novos moradores, fez com que a economia crescesse a um ritmo superior à média do país. Entre 1990 e 1996, o PIB mato-grossense aumentou quase 4\% ao ano, de acordo com estatísticas encontradas em Portal Brasil (2003), enquanto que no mesmo período o crescimento do PIB brasileiro foi de 2,8\% ao ano, de acordo com estatísticas do IBGE. Um dos motivos é a política de benefícios fiscais adotada pelo governo estadual em conjunto com a Sudam. Até 2003, as empresas que pretendam instalar-se na região amazônica pagavam apenas 25\% de imposto de renda. Já o estado parcela em até 30 anos o pagamento do ICMS. No setor agrícola, os produtores de algodão têm um desconto de 75\% no ICMS desde 1997, o que contribui para que Mato Grosso se torne líder nacional nesse segmento onde responde por quase $41 \%$ da produção. 
O município de Sorriso é o maior produtor estadual e nacional de soja, além de possuir a maior capacidade de armazenamento de grãos do estado (três milhões de toneladas), segundo a sua Secretaria Municipal de Agricultura. Seu volume de produção na safra de 2001/2002 foi de 2.077.430 toneladas, representando 2,8\% da safra anual brasileira da cultura e $18 \%$ da safra do estado, com produtividade média de 3,48 t / ha. Dos 890 mil hectares de área total do município, 509 mil são postos a serviço da produção do grão, segundo a Prefeitura Municipal e o Sindicato Rural de Sorriso. De acordo com dados do IBGE, Sorriso é seguida por Campo Novo do Parecis e Sapezal, ambos em MT. Juntos, em 2001, plantaram 526.406 hectares e produziram 1.623.031 de toneladas do grão.

Por sua relevância na produção nacional e regional, o segmento da soja responde atualmente por quase metade da produção de grãos do país. Dada a sua grande importância tanto para a economia do estado do Mato Grosso quanto para a do Brasil como um todo, optou-se por enfatizar a cultura da soja, dedicando um item exclusivamente àmesma.

\subsection{O setor produtivo da soja no Brasil}

São várias as atividades econômicas que constituem o complexo agro-alimentar brasileiro, destacando-se entre elas, o sistema agroindustrial da soja, que por sua vez, sofre forte concorrência mundial, com tendências a se acirrar no próximo decênio.

Lazzarini e Nunes (1998), em sua delimitação analítica do Sistema Agroindustrial (SAG) da soja, enumeraram os segmentos que o constituem, sendo eles: - Indústria de Insumos Agrícolas: diretamente relacionado com a produção agrícola, este elo é representado por indústrias de fertilizantes, defensivos, máquinas, etc.

- Produção Agrícola: representado pelos diversos sistemas de produção.

- Originadores: representados geralmente por exportadoras, cooperativas, corretoras e armazenadoras de grãos, que são os agentes que realizam operações de aquisição, armazenagem e distribuição de grãos junto ao produtor. 
- Indústrias esmagadoras, refinadoras e produtoras de derivados de óleo: o farelo de soja destinado à exportação é transacionado pelas próprias indústrias ou tradings, já o farelo de soja para consumo interno é absorvido pela indústria de rações e indústria processadora de soja. Com relação ao óleo, seu processamento é constituído das seguintes etapas: esmagamento, degomagem e refino. $\mathrm{O}$ óleo parcialmente refinado pode ser transformado em produtos mais elaborados e com maior valor agregado. Outros produtos derivados do processamento da soja são transacionados diretamente com outras indústrias.

- Distribuidores: representados pelos setores atacadista e varejista, estabelecem o elo entre a indústria e os consumidores finais.

- Consumidores finais: representados tanto pelos compradores industriais nas vendas externas efetuadas por tradings e indústrias processadoras, quanto consumidores finais de produtos de soja e derivados destinados ao mercado interno.

Como principais produtos deste SAG, identificaram:

- Commodities para o mercado externo: destacando-se o farelo de soja, grãos e os óleos bruto e refinado.

- Commodities para o mercado interno: destacando-se a soja em grãos, o farelo destinado para a indústria de rações e os óleos bruto e refinado destinados para a indústria de processamento de alimentos.

- Produtos de maior valor agregado para o mercado interno: destacando-se as margarinas, halvarinas, cremes vegetais, maioneses, molhos prontos etc.

- Outros produtos: destacando-se a lecitina; a soja para alimentação humana, como molhos, bebidas, a farinha de soja; dentre outros.

Segundo Tosto (1996), a soja é considerada a mais importante oleaginosa cultivada no mundo, produzindo mais proteína por hectare que qualquer outra cultura, sendo atualmente a mais barata fonte de proteína existente. O grande número de estudos em torno desta leguminosa se deve à sua importância para a economia doméstica e mundial.

De acordo com Moraes (2001), embora introduzida no Brasil em 1908 com a chegada dos primeiros imigrantes japoneses, o cultivo da soja somente se expandiu a 
partir da década de 70, em decorrência tanto do interesse por parte das indústrias de óleo quanto da crescente demanda internacional.

A cultura da soja tem grande importância no cenário econômico brasileiro, tanto no fornecimento interno de alimentos, quanto na obtenção de divisas para o país, por representar em torno de $10 \%$ das nossas exportações, segundo estatísticas do Ministério do Desenvolvimento, Indústria e Comércio Exterior (MDIC, 2003). Em decorrência da importância da soja para a economia nacional, Santos (2000) realizou estudos sobre a evolução de sua produção e do seu processamento industrial, confirmando as características distintas entre as regiões produtoras de soja no Brasil no período de 1970 a 1999, nas suas três fases de crescimento.

De 1970 a 1979 a expansão se deu na região Sul do país, que ficou conhecida como "tradicional", pelo fato de ter sido pioneira na produção agrícola de soja; de 1980 a 1989 se destacou a expansão para a região dos cerrados, conhecida como de “fronteira”, mais especificamente Centro-Oeste e Minas Gerais; e de 1990 a 1999 houve a expansão na região Nordeste, destacando-se os estados da Bahia e Maranhão, além da continuidade da expansão nas demais regiões.

Segundo Padilha (1997), a partir da década de sessenta, a produção nacional de soja ganhou significativa importância relativa no cenário mundial, com forte aumento na área plantada, produtividade e produção. Mereceu, assim, a atenção dos formuladores de política econômica, sendo considerado um produto estratégico pelo governo, principalmente no que tange ao desenvolvimento de tecnologias aplicadas e ao volume de recursos alocados pelo crédito rural e política de preços mínimos. Some-se a isso, de acordo com Richetti (2000), o significativo aumento real do preço internacional dos produtos primários na década de 70 e o rápido crescimento da avicultura brasileira no final da década de 60 e início da década de 70.

Lazzarini e Nunes (1998), afirmaram que houveram mudanças estruturais no setor produtivo da soja, objetivando o aumento da eficiência produtiva, dentre elas o deslocamento da produção para os cerrados como forma de minimizar os custos de frete através da redução das distâncias entre os agentes; e o estabelecimento de novos corredores para exportação, promovendo também um processo de "fusões e aquisições" 
entre os agentes como fatores determinantes para alteração do fluxo de produtos observado no Brasil.

De 1970 para 2000, a produção de 1,5 milhão de toneladas de soja em 1,3 milhão de hectares passou a 31,7 milhões de toneladas em 13,5 milhões de hectares, ilustrando o aumento da produtividade, decorrente principalmente da utilização de variedades mais produtivas. A previsão, segundo dados do IBGE, é de que de 2002 para 2003 a produção passe dos 41,9 milhões de toneladas para 49 milhões de toneladas. Dados do IBGE indicam também que a área de soja plantada nos últimos 11 anos cresceu menos que $1 \%$ ao ano, enquanto que a produção, no mesmo período, cresceu $94 \%$.

Santos (2000) conclui também que o aumento do rendimento médio da soja foi obtido por outros fatores além do crédito agrícola, como por exemplo, o desenvolvimento de pesquisas permitindo a expansão da cultura da soja através de tecnologia direcionada à várias regiões.

A competitividade brasileira em produção de soja assenta-se mais em vantagens comparativas, como por exemplo, as características edafoclimáticas e expansão de fronteiras agrícolas, do que em vantagens competitivas.

Segundo Caixeta Filho (1998), um dos pontos de estrangulamento da competitividade enfrentado pelo setor é o chamado "Custo Brasil", referente à soma dos custos de frete e portuários, deficiências na infra-estrutura logística e de armazenagem, carga tributária, encargos trabalhistas e impostos vinculados ao faturamento das firmas, diminuindo as vantagens competitivas adquiridas no segmento de produção agrícola.

O segmento armazenagem, segundo Costa \& Tosta (1995), participa, com maior ou menor intensidade, de todo o ciclo econômico de produtos alimentares, desde a produção, comercialização "in natura", industrialização, consumo no atacado e no varejo, até os estágios de exportação e importação. Com relação à modalidade, os armazéns podem ser convencionais, para o armazenamento de produtos ensacados, industrializados e fibras, ou então, a granel, utilizados para armazenagem de produtos 
granelizáveis. No que diz respeito à posse, estes podem ser privados ou públicos. Segundo dados da CONAB, a capacidade de armazenamento estático de grãos no Brasil em 2001 era de 88,6 milhões de toneladas.

Em relação àcapacidade instalada de processamento de oleaginosas, em 2001 a mesma era de 107.950 toneladas / dia, sendo que só o esmagamento de soja no período de fevereiro de 2001 a janeiro de 2002 foi de 22,77 milhões de toneladas, conforme estatísticas da Associação Brasileira das Indústrias de Óleos Vegetais (ABIOVE, 2003).

O principal problema do setor industrial é com relação ao teor de proteína contido no grão de soja. A demanda da indústria é por um grão com maior teor de proteína, porém este fator está inversamente relacionado ao aumento da produtividade da soja. Dessa maneira, nem sempre os cultivares mais produtivos em campo são mais interessantes para a indústria.

O Brasil ocupa a segunda posição na produção mundial de soja, respondendo por $23,5 \%$ da oferta global com 41,90 milhões de toneladas, perdendo apenas para os Estados Unidos, responsável por 40,7\% com 74,3 milhões de toneladas; e à frente da Argentina que detêm 16,8\% com 30 milhões de toneladas (FAO, 2003).

As políticas dos países desenvolvidos que procuram restringir o acesso aos seus mercados domésticos, agravadas pelos subsídios à exportações, a estabilização do consumo de proteínas de origem animal nos países de alta renda per capita, o surgimento de produtos substitutos dos óleos vegetais e proteínas para ração animal e o aumento de produção dos países competidores, são alguns fatores que pressionam a posição brasileira no mercado mundial de soja e seus derivados.

No que diz respeito à participação do complexo soja na Balança Comercial brasileira, um dos fatores relevantes ao aumento das exportações de grãos, a partir de 1997, é o efeito da adoção da Lei Kandir, beneficiando a exportação de grãos e demais produtos primários em detrimento das exportações de produtos com algum grau de processamento, como é o caso do farelo de soja. O incentivo à exportação deu-se na forma de isenção de ICMS dos grãos destinados à exportação, aumentando a competitividade dos grãos brasileiros no mercado internacional. 
De acordo com dados da CONAB (2003), de 1999 para 2002, a receita brasileira com exportação de soja em grãos aumentou em 90\%, de US\$ 1.593,29 milhões para US\$ 3.031,98 milhões. Os principais destinos foram China, Holanda, Espanha, Portugal, Japão e França.

As exportações derivadas do complexo soja totalizaram, em 2002, cerca de US\$ 6 bilhões; sendo que as exportações de grãos deram-se na ordem de 15,9 milhões de toneladas e US\$ 3,031 bilhões; as exportações de farelo participaram com aproximadamente 12,52 milhões de toneladas e US\$ 2,198 bilhões; finalmente, os óleos bruto, refinado e outros com aproximadamente 1,93 milhões de toneladas e US\$ 0,778 bilhões. Deve-se ressaltar ainda que, estas exportações do complexo soja representaram em torno de $24 \%$ do total das exportações do agronegócio brasileiro, que foram de US\$ 24,86 bilhões em 2002 e, em torno de $10 \%$ do total das exportações brasileiras, que foram de US\$ 60,36 bilhões no mesmo período (CONAB, 2003).

A importância estratégica da produção de oleaginosas, além do suprimento da demanda mundial de óleos vegetais, reside na capacidade de ofertar proteínas para a produção de carnes a preços competitivos.

Em relação ao consumo do produto, decorrente do aumento no consumo interno de carnes proporcionado pelo Plano Real, verifica-se um aumento da demanda interna de farelo de soja destinado à ração animal. Nos últimos 30 anos, as mudanças de hábitos alimentares provocaram um aumento do consumo per capita de carnes. Segundo Sartori (2002), em 1970, esse consumo no mundo era de 27,2 kg por pessoa / ano e em 2002 o mesmo deveria chegar em $38,7 \mathrm{~kg}$, ou seja, a humanidade está mudando sua dieta e aumentando a participação de proteína animal, com o crescimento no consumo de 42,3\%. O aumento mais acentuado foi do consumo de carnes brancas (frango e suíno). Para a produção dessas carnes, são necessárias proteínas vegetais, sendo que $68 \%$ da produção mundial de proteínas vegetais advêm da soja. Ou seja, não se pode analisar o preço da soja apenas avaliando sua produção, seu consumo e estoque, mas a mudança de hábitos alimentares e o PIB per capita, principalmente dos países em desenvolvimento que estão crescendo mais vegetativamente e economicamente do que os países desenvolvidos. 
De acordo com as informações apresentadas neste tópico e com as apresentadas nos tópicos anteriores, pode-se verificar a grande importância que tem o estado do Mato Grosso no contexto nacional em termos de sua produção agrícola, principalmente de soja, para o suprimento interno do país e para o mercado externo. Sendo assim, é fundamental que exista uma infra-estrutura de transportes adequada, tanto para o escoamento da produção agrícola, quanto para o suprimento de insumos nas principais regiões produtoras. No entanto, o que se observa no Brasil é que este segmento da cadeia produtiva constitui um dos pontos de estrangulamento da competitividade nacional em produção agrícola, contribuindo positivamente para o aumento do "Custo Brasil". Para um melhor entendimento do significado da importância que tem a infra-estrutura de transportes no desempenho de uma economia, será apresentado a seguir uma descrição do sistema de transportes de cargas agrícolas no Brasil. 


\subsection{Transporte de cargas agrícolas no Brasil}

Um dos segmentos que interfere na eficiência de vários setores da economia de um país é o transporte, e na agricultura, é sem dúvida uma das mais importantes etapas da pós-colheita. Entretanto, de acordo com Marques e Caixeta Filho (1998), o sistema de transportes no Brasil é precário em todos os modais, tornando-se necessárias algumas modificações. A maior parte do transporte de cargas agrícolas é feita via modal rodoviário, mais caro e ineficiente para transportar grãos do que outros meios, fazendo com que essa fase da comercialização acabe onerando o produto e se tornando um dos gargalos àcompetitividade brasileira na produção agrícola, e de acordo com depoimento de José Vicente Caixeta Filho (Stuani, 2002a), um dos gargalos encontra-se na falta de intermodalidade, ou seja, a má integração entre os meios de transporte disponíveis, o que significa que o país precisa investir mais em terminais de transferência de carga. A falta de logística no setor diminui a capacidade de coordenação das etapas de carregamento, transporte e descarregamento dos produtos no momento e no local adequados.

De acordo com Pires (2002), o modal ferroviário é naturalmente vocacionado para o transporte de cargas de baixo valor agregado e para grandes distâncias, vocação esta que pode ser percebida na representatividade deste modal na matriz de transporte de diversos países de grandes dimensões continentais, como a China (37\% do total de cargas transportadas), EUA (44\%) e Rússia (60\%), bem como nos tipos de produto tipicamente transportados por este modal: minério de ferro, produtos siderúrgicos, produtos agrícolas, carvão, fertilizantes, dentre outros.

Entretanto, no caso do Brasil, um país de grande extensão territorial, este modal de transporte nunca alcançou a representatividade obtida em outros países de semelhantes extensões. A participação do modal ferroviário no total de cargas transportadas no país variou aproximadamente de $20 \%$ a $23 \%$ entre as décadas de 80 e 90, colocando-o na companhia de diversos países europeus, como França e Alemanha, que possuem extensões territoriais significativamente menores. Adicionalmente, a participação do transporte ferroviário de cargas no Brasil têm sido restrita ao segmento de curtas distâncias, em que as vantagens dos custos e serviços ferroviários não são 
significativas, devendo-se ressaltar que, para longas distâncias, a participação do modal ferroviário é a menor dentre todos os outros modais de transporte no Brasil. (Pires, 2002)

Segundo Geiling (1996), com a atual globalização da economia e a abertura das fronteiras exigidas pelo Mercosul, o país deparou-se com a necessidade de melhorar sua rede de infra-estrutura dos transportes para tornar-se competitivo nas relações comerciais internacionais. Para escoar o crescente volume da produção agrícola, medidas devem ser tomadas no sentido de modificar a matriz de transportes, incentivando a intermodalidade, que por sua vez, tem fundamental importância no desenvolvimento individual dos modais, já que estimula a competição por novos mercados.

O setor agrícola brasileiro sempre foi o mais penalizado pelos altos custos de transporte e portuários, em decorrência da necessidade de transportar grandes volumes de cargas de baixo valor agregado a grandes distâncias e ao mesmo tempo enfrentar uma acirrada competição no mercado internacional. O cenário, porém, registrou mudanças nos últimos dez anos. Os investimentos realizados nos transportes hidroviário e ferroviário e a privatização de portos e ferrovias nos anos 90 trouxeram melhoras, criando alternativas nas regiões Norte e Nordeste, além dos tradicionais corredores de exportação, conforme descritos por Lício e Corbucci (1996):

O Corredor Noroeste, cuja área de influência está localizada principalmente na região pré-amazônica, envolve uma grande área agricultável localizada no norte do estado de Mato Grosso e leste de Rondônia. Seus principais modais de transportes são o fluvial e o rodoviário: Rio Amazonas, entre sua foz e Itacoatiara (AM); Rio Madeira, entre Porto Velho (RO) e Itacoatiara (AM); BR-364, entre Porto velho e entroncamento com a Rodovia MT 235; e BR-163 (Cuiabá-Santarém).

O Corredor Centro-Norte, abrange o Tocantins, Sul do Maranhão e do Piauí, Sudeste do Pará, Leste do Mato Grosso e Noroeste de Goiás, tendo sua área de abrangência constituída por cerrados, com condições propícias à produção de grãos, pecuária e silvicultura. Tem como principais trechos: Parte do Rio Araguaia, do Rio das Mortes em Mato Grosso, do Rio Tocantins, da BR-010 (Belém-Brasília), da Ferrovia 
Norte-Sul e da Ferrovia Carajás entre Açailândia (MA) e o Porto da Ponta da Madeira em São Luís (MA).

O Corredor Centro-Leste é destinado a escoar a produção da região noroeste do Estado de Minas Gerais e do centro de Goiás. Envolve basicamente a utilização da Estrada de Ferro Vitória-Minas entre o Porto de Tubarão e Belo Horizonte, e de um ramal ferroviário entre Belo Horizonte e Pirapora (MG).

O Corredor Nordeste abrange todas as regiões localizadas no norte de Minas Gerais, Bahia e Pernambuco, e é constituído da extensão navegável do Rio São Francisco entre Pirapora (MG) e Petrolina (PE), e da malha rodoviária a partir de Petrolina até as principais capitais e portos nordestinos.

No Apêndice 3 encontram-se os mapas de alguns estados, os quais permitem a visualização dos modais que compõem os corredores de transportes.

Segundo Coelho (2003), após a implantação dos corredores multimodais de transportes e da privatização das ferrovias e dos portos, efetuadas a partir de 1995, os custos de transportes de grãos foram reduzidos em $40 \%$ na média e o custo portuário, em 50\%. Paralelamente à estrutura ferroviária privatizada, nasceu a Ferronorte, uma concessão de 90 anos outorgada em 1989 e com início de operação no ano de 1999. As estatísticas relativas ao seu desempenho são ainda muito recentes.

Em 2002, os controladores da Ferronorte uniram-se àconcessionária Ferroban, ex-Fepasa, para criar a holding Brasil Ferrovias, a mais nova empresa do setor ferroviário no país, que faz a integração das operações das malhas ferroviárias da Ferronorte, Novoeste, Ferroban e Portofer, substituindo a Ferropasa, holding que controlava essas quatro malhas. A criação desta holding, cujo objetivo é aumentar a eficiência do transporte da safra agrícola (em especial, grãos e farelo de soja) da região Centro-Oeste até o Porto de Santos, deverá favorecer um aumento da participação dos trens no transporte de mercadorias a média e a longa distâncias.

$\mathrm{O}$ aumento gradativo do transporte pela Ferronorte acontece simultaneamente com a expansão das lavouras de soja em Mato Grosso, com significativa parte dessa produção voltada para o mercado internacional, o que significa maior fluxo de escoamento para os portos de Santos (SP), Paranaguá (PR) e Itacoatiara (AM). 
Parte da distribuição da soja do norte e centro do Mato Grosso é realizada através da ligação Cuiabá (MT) - Santarém (PA), por meio da rodovia BR-163. Segundo Stuani (2002b), outro corredor de exportação reivindicado com insistência pelas grandes companhias de soja junto ao governo federal é a pavimentação desta rodovia, que quando asfaltada escoará soja pelos portos fluviais de Itaituba e Santarém, e deverá movimentar três milhões de toneladas com economia anual de US\$ 60 milhões em gasto com frete. A precária condição da estrada, sujeita a erosões, é tida como um dos principais gargalos da logística do Centro-Oeste.

De acordo com depoimento de Marcos Aurélio Ioris, gerente da Unidade da Bunge Alimentos em Nova Mutum-MT (Ferreira, 2003), as péssimas condições das estradas, associadas ao elevado preço do combustível, fazem com que os gastos com transporte representem $30 \%$ do volume de negócios das indústrias de soja que atuam no Mato Grosso. Ele afirma que as dificuldades começam nas estradas vicinais e se estendem pela BR-163, que está praticamente intransitável no trecho entre Sinop a Itaúba, no norte do estado.

Dadas as precárias condições das rodovias brasileiras, o alto custo do transporte rodoviário, a safra recorde de grãos e a necessidade de um meio de transporte mais prático, rápido e eficiente, a malha ferroviária tem se tornado uma opção cada vez mais fundamental para o escoamento de soja destinada àexportação.

Com o intuito de avaliar a importância da agricultura na estrutura produtiva do Estado do Mato Grosso, bem como das relações desse Estado com o resto do país, o presente trabalho faz uso de uma matriz insumo-produto inter-regional para o Mato Grosso e resto do Brasil referente ao ano de 1999. O instrumental é adequado aos objetivos do trabalho, posto que permite detalhar a malha de relações entre os distintos setores da economia mato-grossense. O próximo capítulo detalha a metodologia e os procedimentos utilizados. 


\section{METODOLOGIA}

\subsection{Instrumental teórico}

\subsubsection{A teoria de análise insumo-produto}

Há 245 anos, mais precisamente em 1758, surgia a preocupação de se verificar a interdependência das atividades econômicas, com a publicação do Tableau Économique do fisiocrata François Quesnay (Sandroni, 1989).

De acordo com Davis (1968), o primeiro economista a afirmar, explicitamente, que o preço de uma mercadoria dependia do preço de todas as outras mercadorias foi Walras, que desenvolveu um modelo mostrando a interdependência entre os diferentes setores, bem como as demandas concorrentes de cada um para os fatores de produção.

Contudo, somente em 1930 é que foi atingido o ponto mais alto do trabalho iniciado por Quesnay, com os primeiros trabalhos de organização, formalização e aperfeiçoamento dos primeiros estudos sobre as relações interindustriais, realizados pelo economista Wassily Leontief (Feijó et al., 2001).

Wassily Leontief nasceu em São Petersburgo, formou-se em economia pela Universidade de Leningrado em 1925, e fez o seu doutorado na Universidade de Berlim. Em 1928 publicou parte da sua tese no artigo "Die Wirtschalt als Kreislaur”, onde descreveu um modelo de dois setores de insumo-produto, construído para descrever a produção, distribuição e o consumo. Em 1928/29 foi Consultor do Ministério das Estradas de Ferro, na China, mudando-se para os Estados Unidos em 1931, onde foi trabalhar no National Bureau of Economic Research, Nova Iorque, tornando-se professor no departamento de economia na Universidade de Harvard, EUA, em seguida. 
Foi nesta Universidade onde começou a construção das primeiras matrizes de insumoproduto para a economia americana, que juntamente com o modelo matemático foram publicadas em 1936 e 1937 (Leontief, 1966). Em 1973 recebeu o prêmio Nobel de economia. Em 1975 tornou-se professor no departamento de economia da New York University, onde lecionou até o seu falecimento, em 1999 (Guilhoto ${ }^{5}$ ).

De acordo com Crocomo (1998), o modelo de Leontief consiste na sistematização da inter-relação existente entre os insumos e os produtos no sistema econômico, permitindo visualizar a inter-relação e operações dos agentes no mesmo, o que vai de encontro à posição macroeconômica Keynesiana, a qual contribui para a elaboração das contas nacionais em uma visão agregada.

Algumas referências básicas no que diz respeito ao assunto incluem BulmerThomas (1982), Miernyk (1965), Richardson (1972), Yan (1969), Chenery e Clark (1959), Isard et al. (1960), Stone (1961) e Yamada (1961), dentre outros.

Além destes textos introdutórios, existem diversos livros enfatizando a estrutura matemática do modelo Insumo-Produto, tais como Morgenstern (1954), e enfatizando pressuposições econômicas e dificuldades práticas na implementação das análises Insumo-Produto, como National Bureau of Economic Research (1955).

Em adição ao trabalho original de Leontief, existem diversos artigos de conferências internacionais com aplicações e técnicas em Insumo-Produto, como por exemplo, Polenske (1989).

Segundo Moreto (2000), o método de insumo-produto transformou-se em instrumento de planejamento econômico largamente aceito e num importante guia para os tomadores de decisões em um grande número de países.

\footnotetext{
${ }^{5}$ GUILHOTO, J.J.M. (Universidade de São Paulo, São Paulo, SP). Análise de insumo-produto: teoria e fundamentos (Em elaboração)
} 


\subsubsection{Fundamentos da análise insumo-produto}

\subsection{Notação e relações fundamentais ${ }^{6}$}

Um sistema insumo-produto consiste, em sua estrutura matemática, de um conjunto de $n$ equações lineares com $n$ incógnitas, podendo ser representado através de notação matricial (Miller \& Blair, 1985).

As relações fundamentais do modelo insumo-produto podem ser representadas conforme ilustrado no Quadro 1.

\begin{tabular}{|l|c|c|c|c|c|c|}
\hline & $\begin{array}{c}\text { Setores } \\
\text { Compradores }\end{array}$ & $\begin{array}{c}\text { Consumo } \\
\text { Famílias }\end{array}$ & Governo & Investimento & Exportações & Total \\
\hline $\begin{array}{l}\text { Setores } \\
\text { Vendedores }\end{array}$ & $\mathrm{Z}$ & $\mathrm{C}$ & $\mathrm{G}$ & $\mathrm{I}$ & $\mathrm{E}$ & $\mathrm{X}$ \\
\hline Importação & $\mathrm{M}$ & $\mathrm{Mc}$ & $\mathrm{Mg}$ & $\mathrm{Mi}$ & & $\mathrm{M}$ \\
\hline Impostos & $\mathrm{T}$ & $\mathrm{Tc}$ & $\mathrm{Tg}$ & $\mathrm{Ti}$ & $\mathrm{Te}$ & $\mathrm{T}$ \\
\hline $\begin{array}{l}\text { Valor } \\
\text { Adicionado }\end{array}$ & $\mathrm{W}$ & & & & & $\mathrm{W}$ \\
\hline Total & $\mathrm{X}$ & $\mathrm{C}$ & $\mathrm{G}$ & $\mathrm{I}$ & $\mathrm{E}$ & \\
\hline
\end{tabular}

Quadro 1 - Exemplo de uma tabela de Insumo-Produto.

Fonte: Adaptado de Guilhoto, op. cit., p.48.

onde:

$Z$ é o fluxo monetário entre os setores da economia;

$C$ é o consumo dos produtos dos setores pelas famílias;

$G$ é o gasto do governo junto aos setores;

I é a demanda por bens de investimento produzidos nos setores;

\footnotetext{
${ }^{6}$ Baseado em Miller e Blair (1985)
} 
$E$ é o total exportado pelos setores;

$X$ é o total de produção dos setores;

$T$ é o total de impostos indiretos líquidos pago pelos setores;

$M$ é a importação realizada pelos setores;

$W$ é o valor adicionado gerado pelos setores;

A partir do Quadro 1 permite-se estabelecer a seguinte igualdade:

$$
X+C+G+I+E=X+M+T+W
$$

Eliminando $\mathrm{X}$ de ambos os lados, tem-se:

$$
C+G+I+E=M+T+W
$$

Rearranjando:

$$
C+G+I+(E-M)=T+W
$$

Portanto, a tabela insumo-produto preserva as identidades macroeconômicas.

De acordo com Considera (1997), o conjunto de tabelas de um modelo insumoproduto pode ser dividido em tabelas básicas, atualmente denominadas tabelas de recursos e usos, contendo informações como produção, consumo intermediário, salários e encargos sociais pagos, investimentos etc.; e tabelas resultantes da aplicação de um modelo sobre as informações contidas nestas primeiras, que servem para obtenção dos parâmetros desse modelo. Sua derivação mais conhecida é a matriz de Leontief.

A construção do modelo se dá a partir de dados observados de uma particular área econômica, que pode ser uma nação, um estado, ou qualquer região, para um determinado período de tempo, geralmente um ano. A atividade econômica está dividida em uma série de segmentos ou setores produtivos, também chamados de indústrias. Os fluxos inter-setoriais ou inter-industriais (fluxos de produto entre os diferentes setores ou indústrias) são medidos em valores monetários.

Em seu modelo estático, Leontief parte de uma série de pressuposições econômicas, objetivando simplificá-lo para melhor visualização. Uma primeira hipótese seria a inexistência de produção conjunta ou subprodutos dentro do processo produtivo, isto é, cada produto é produzido por um único setor e cada setor produz um único 
produto.

Costuma-se denotar o valor monetário observado do fluxo de um setor produtivo $i$ para outro setor produtivo $j$, de $z_{i j}$. Melhor dizendo, $z_{i j}$ representa o quanto da produção do setor $i$ é comprada pelo setor $j$, para ser utilizada como insumo.

Se a economia estiver dividida em $n$ setores, $X_{i}$ representar o produto total do setor $i$ e $Y_{i}$ a demanda final pelo produto do setor $i$, pode-se escrever:

$$
X_{i}=z_{i 1}+z_{i 2}+\ldots+z_{i i}+\ldots+z_{i n}+Y_{i}
$$

A equação (2) representa as vendas dos produtos do setor $i$. O termo $X_{i}$ representa a produção total do setor $i$. Os termos da direita representam as vendas do setor $i$ para atender a demanda dos fluxos inter-industriais $\left(z_{i 1}+z_{i 2}+\cdots+z_{i i}+\cdots+z_{\text {in }}\right) \mathrm{e}$ as outras demandas finais $Y_{i}$. As vendas de produtos dos demais setores da economia podem ser representadas pela mesma equação.

Assim como as linhas de uma matriz insumo-produto mostram como a produção de cada setor da economia é distribuída através de suas vendas para os demais setores, consumo das famílias $(C)$, investimentos privados $(I)$, gastos do governo $(G)$ e exportações $(E)$; as colunas mostram como cada setor obtém dos demais os insumos necessários para o desenvolvimento de sua atividade econômica ou seja, as compras de insumos intermediários produzidos pelas demais indústrias, bem como outros insumos não industriais de produção requeridos no processo produtivo, que correspondem na matriz às partes componentes do setor pagamentos: impostos $(T)$, importações $(M)$ e os itens componentes do valor adicionado $(V A)$ - remuneração do trabalho, capital e terra.

A partir dos fluxos inter-setoriais $\left(z_{i j}\right)$ e da produção total $\left(X_{i}\right)$ de cada setor, torna-se possível a determinação de um valor, denominado coeficiente técnico ou coeficiente insumo-produto, da seguinte forma:

$$
a_{i j}=z_{i j} / X_{j}
$$

Uma outra pressuposição fundamental na análise insumo-produto é a de que os coeficientes técnicos de cada setor produtivo permanecem constantes ao longo do período de análise, o que significa dizer que as proporções de insumos utilizadas por 
cada setor produtivo não se alteram durante o mesmo, e dependem exclusivamente da produção de cada setor no período em questão.

Partindo destes pressupostos, a função de produção definida segundo a teoria de Leontief, é do tipo:

$$
X_{j}=\min \left(\frac{z_{1 j}}{a_{i j}}, \frac{z_{2 j}}{a_{2 j}}, \cdots, \frac{z_{n j}}{a_{n j}}\right)
$$

onde a quantidade máxima a ser produzida será determinada pela quantidade disponível do fator de produção mais escasso.

Substituindo os fluxos de insumo $\left(z_{i j}\right)$ pelos produtos dos coeficientes técnicos $\left(a_{i j}\right)$ vezes a produção total $(\mathrm{X})$ em cada setor, nas equações das vendas de cada setor, obtém-se:

$$
\begin{aligned}
& X_{1}=a_{11} X_{1}+a_{12} X_{2}+\cdots+a_{1 i} X_{i}+\cdots+a_{1 n} X_{n}+Y_{1} \\
& X_{2}=a_{21} X_{1}+a_{22} X_{2}+\cdots+a_{2 i} X_{i}+\cdots+a_{2 n} X_{n}+Y_{2} \\
& \vdots \\
& X_{i}=a_{i 1} X_{1}+a_{i 2} X_{2}+\cdots+a_{i i} X_{i}+\cdots+a_{i n} X_{n}+Y_{i} \\
& \vdots \\
& X_{n}=a_{n 1} X_{1}+a_{n 2} X_{2}+\cdots+a_{n i} X_{i}+\cdots+a_{n n} X_{n}+Y_{n}
\end{aligned}
$$

Colocando este sistema de equações na forma matricial:

$$
\left[\begin{array}{c}
X_{1} \\
X_{2} \\
\vdots \\
X_{n}
\end{array}\right]=\left[\begin{array}{cccc}
a_{11} & a_{12} & \cdots & a_{1 n} \\
a_{21} & a_{22} & \cdots & a_{2 n} \\
\vdots & \vdots & \cdots & \vdots \\
a_{n 1} & a_{n 2} & \cdots & a_{n n}
\end{array}\right]\left[\begin{array}{c}
X_{1} \\
X_{2} \\
\vdots \\
X_{n}
\end{array}\right]+\left[\begin{array}{c}
Y_{1} \\
Y_{2} \\
\vdots \\
Y_{n}
\end{array}\right]
$$

Obtêm-se a matriz $A$, dos coeficientes técnicos diretos, que apresenta todas as relações diretas dentro do sistema produtivo, ou seja, daqueles insumos utilizados diretamente na produção de cada setor. O coeficiente $a_{11}$, por exemplo, representa a proporção fixa do produto do setor um utilizado como insumo produtivo na produção do setor um, o coeficiente $a_{12}$ representa a proporção fixa do produto do setor um utilizado 
como insumo produtivo na produção do setor dois, e assim por diante.

Uma vez que se procure obter a produção total necessária para atender à demanda final de cada setor, é possível resolver o sistema de equações para X. De maneira sintética:

$$
X=A X+Y \quad \Rightarrow \quad X-A X=Y \quad \Rightarrow \quad X(I-A)=Y
$$

onde I representa a matriz identidade. Se a matriz (I - A) for não-singular, e, portanto inversível, tem-se que:

$$
X=(I-A)^{-1} Y
$$

A matriz $(I-A)^{-1}$, dos coeficientes técnicos diretos e indiretos, é denominada Inversa de Leontief, a partir da qual, é possível determinar o nível de produção $(X)$ necessário para atender àdemanda final de cada setor $(Y)$. Seus coeficientes representam as proporções de insumos utilizados direta e indiretamente no processo produtivo de cada setor.

\subsection{Organização dos dados de insumo-produto}

Em 1979 foi construída a primeira Matriz Insumo-Produto (MIP) Nacional pelo Instituto Brasileiro de Geografia e Estatística (IBGE), órgão oficial do governo federal responsável pela elaboração das Matrizes Nacionais de Insumo-Produto, utilizando-se dados referentes ao ano de 1970. Foram construídas as Matrizes para 1975, 1980, 1985, 1990, e a partir daí, sua elaboração passou a ser anual. Ainda assim, a divulgação das MIP apresenta uma defasagem de no mínimo três anos, justificada pelo extenso período entre a coleta dos dados levantados junto a cada setor da economia e sua elaboração pelo IBGE. Também elaboradas pelo IBGE, as Contas Nacionais, das quais se deriva a Matriz Insumo-Produto, referentes a um dado ano X, são apresentadas no ano seguinte como uma versão preliminar. Com defasagem de dois anos é divulgada a primeira revisão das Contas, e ao final do terceiro ano, as Contas Nacionais em sua versão definitiva, a partir das quais, a Matriz Insumo-Produto de um dado ano $\mathrm{X}$ é disponibilizada. 
Para utilizar matrizes mais recentes torna-se necessário elaborá-las com dados provenientes das Contas Nacionais em suas versões preliminares e primeira revisão.

Os dados apresentados pelo Sistema de Contas Nacionais aparecem sinteticamente, conforme o Quadro 2:

\begin{tabular}{|c|c|c|c|}
\hline I - Tabela & rso & erviços & \\
\hline OFERTA & $=$ & PRODUÇÃO & $+\quad$ IMPORTAÇÃO \\
\hline II - Tabela & $\mathrm{de}$ & iços & \\
\hline OFERTA & $=$ & CONSUMO INTERMEDIÁRIO & + DEMANDA \\
\hline & & & FINAL \\
\hline COMPON & & CIONADO & \\
\hline
\end{tabular}

Quadro 2 - Tabela de Recursos e Usos.

Fonte: IBGE (2003)

A Tabela de Recursos de Bens e Serviços apresenta os dados de oferta total a preços ao consumidor (preços de mercado); entretanto, discrimina as margens de comércio e transporte, os impostos e as importações, possibilitando a obtenção dos valores em Oferta Nacional a Preços Básicos ${ }^{7}$. Os produtos estão descritos nas linhas e os setores nas colunas. Esta tabela é equivalente à matriz V' (matriz de produção transposta).

A Tabela de Usos de Bens e Serviços não discrimina margens, impostos e importações, tornando-se necessário um trabalho adicional para transformá-la em duas outras: consumo nacional a preços básicos e consumo importado a preços básicos. Uma metodologia utilizada para a construção da Matriz Insumo-Produto utilizando dados preliminares das Contas Nacionais pode ser encontrada em Guilhoto et al. (2002).

Os dados que aparecem na matriz Insumo-Produto podem ser esquematizados

\footnotetext{
${ }^{7}$ Oferta Nacional $=$ Oferta Total - Importações

Preços Básicos $=$ Preços ao Consumidor - Margens - Impostos
} 
conforme apresentado no Quadro 3:

\begin{tabular}{|l|c|c|c|c|}
\hline & $\begin{array}{c}\text { Produtos } \\
\text { Nacionais }\end{array}$ & Setores & $\begin{array}{c}\text { Demanda } \\
\text { Final }\end{array}$ & $\begin{array}{c}\text { Valor da } \\
\text { Produção }\end{array}$ \\
\hline Produtos Nacionais & & $\mathrm{U}$ & $\mathrm{E}$ & $\mathrm{Q}$ \\
\hline Produtos Importados & & $\mathrm{Um}$ & $\mathrm{Em}$ & \\
\hline Setores & $\mathrm{V}$ & $\mathrm{Z}$ & $\mathrm{Y}$ & $\mathrm{X}$ \\
\hline Impostos & & $\mathrm{Tp}$ & $\mathrm{Te}$ & \\
\hline Valor Adicionado & & $\mathrm{W}$ & & \\
\hline Valor da Produção & Q' & $\mathrm{X}$ & & \\
\hline
\end{tabular}

Quadro 3 - Representação esquemática dos dados em um modelo insumo-produto.

Fonte: Adaptado de Feijó et al. (2001)

Baseado na notação do IBGE, adaptado de Feijó et al. (2001), tem-se:

V: matriz de produção, apresentando para cada setor (ou indústria) o valor da produção de cada um dos produtos;

Q: vetor com o valor bruto da produção total por produto;

U: matriz de consumo intermediário nacional, apresentando para cada setor o valor dos produtos de origem interna consumidos;

Z: matriz do consumo intermediário dos setores, cujas linhas representam as vendas dos mesmos e as colunas as compras.

Um: matriz de consumo intermediário importado, apresentando para cada setor o valor dos produtos importados consumidos;

E: matriz da demanda final por produtos nacionais, apresentando o valor dos produtos de origem interna consumidos pelas categorias da demanda final (consumo final das famílias e do governo, exportação, formação bruta de capital fixo e variação de estoques);

Em: matriz da demanda final por produtos importados, apresentando o valor dos produtos de origem externa consumidos pelas categorias da demanda final;

Y: matriz da demanda final por setor, representando a parcela do valor da 
produção de um setor destinada à demanda final. Estes dados não são observados, mas sim calculados a partir de $\mathbf{E}$;

Tp: matriz dos valores dos impostos e subsídios associados a produtos, incidentes sobre bens e serviços absorvidos (insumos) pelas atividades produtivas;

Te: matrizes dos valores de impostos e subsídios associados a produtos, incidentes sobre bens e serviços absorvidos pela demanda final;

$\mathbf{X}$ : vetor com o valor bruto da produção total por setor;

W: vetor com o valor adicionado total gerado pelas atividades produtivas.

Nem sempre é possível aplicar a teoria básica de Leontief, apresentada no item 3.1.1.1.1, nas matrizes divulgadas pelos órgãos responsáveis pela sua construção.

No mundo real, a maioria dos setores produtivos apresenta a produção secundária, ou seja, além de produzirem um bem principal, podem produzir um ou mais sub-produtos, denominados secundários. Isto viola uma das pressuposições básicas da teoria de Leontief, que diz que cada setor produz um único produto e cada produto é produzido por um único setor, inviabilizando a aplicação da mesma nestas matrizes. Este é um dos fatores que torna sempre necessária, a transformação da base de dados efetivamente disponível, à necessidades do modelo teórico.

Segundo Guilhoto, op. cit., p.46, existem duas tecnologias utilizadas de forma a se obter o sistema de insumo-produto originalmente definido por Leontief, quais sejam a Tecnologia Baseada na Indústria, que assume a hipótese de que o mix de produção de um dado setor pode ser alterado, porém este setor mantém a sua participação constante no mercado dos bens que produz; e a Tecnologia Baseada no Produto, que assume a hipótese de que o mix produtivo de cada setor deve permanecer constante, ou seja, para alterar a produção de um determinado bem, o setor deve alterar a produção de todos os outros bens na mesma proporção.

Ambas as tecnologias podem ser aplicadas sob quatro diferentes enfoques:

1) Produto $x$ Produto

2) Produto $x$ Setor

3) Setor x Produto 
4) Setor $x$ Setor

O enfoque setor x setor da Tecnologia Baseada na Indústria ${ }^{8}$ é o mais utilizado na prática, pois acaba ficando mais próximo da realidade em decorrência da sua hipótese de "Market-Share" ou participação constante de cada setor na oferta de cada bem no mercado, o que justifica a sua utilização no presente trabalho.

\subsubsection{Modelos de insumo-produto regionais}

Embora as primeiras aplicações do modelo insumo-produto foram desenvolvidas para estudos das relações internas da economia de uma nação, o recente interesse pela análise econômica em nível regional tem induzido modificações nos modelos visando adaptá-los para investigações de determinadas regiões e suas relações com as demais.

De acordo com Miller e Blair (1985), embora os dados de uma tabela de coeficientes de insumo-produto nacional sejam uma média dos dados relativos aos diversos produtores localizados em regiões específicas, a estrutura de produção de uma determinada região tanto pode ser idêntica quanto bastante diferente daquela registrada na matriz nacional, e quanto menor for uma região, maior será sua dependência em relação à̀ demais, tanto para as exportações quanto para as importações de insumos regionais necessários ao processo produtivo.

Além disso, segundo estes autores, existem modelos para uma única região, denominados modelos regionais, cujos objetivos são quantificar os impactos de uma variação na demanda final por bens produzidos dentro de uma determinada região sobre os seus setores produtivos, e modelos para várias regiões, os chamados modelos interregionais, que além de estudarem os fluxos de produto dentro de cada região, permitem também estudar os fluxos entre as diferentes regiões.

\footnotetext{
${ }^{8}$ Demonstração encontra-se nos Apêndices.
} 


\subsection{Modelos de insumo-produto regionais (uma única região)}

Os primeiros estudos regionais utilizando modelos de insumo-produto referemse aos trabalhos de Isard \& Kuenne (1953), e Miller (1957), os quais estimaram características de algumas economias regionais a partir da matriz A de coeficientes técnicos nacionais, através de um processo de ajustamento, uma vez que não dispunham de coeficientes técnicos regionais específicos. Tal processo de ajustamento consiste na estimativa das porcentagens de oferta de cada setor em uma determinada região, construindo-se um vetor $\mathrm{P}$, que quando pré-multiplicado pela matriz dos coeficientes técnicos nacionais resulta na matriz de coeficientes técnicos regionais da a região a ser estudada. O pressuposto forte deste processo é o de considerar a técnica de produção regional idêntica ànacional.

O estimador das porcentagens de oferta é, então, dado por:

$$
p_{j}^{R}=\frac{\left(X_{j}^{R}-E_{j}^{R}\right)}{\left(X_{j}^{R}-E_{j}^{R}+M_{j}^{R}\right)}
$$

onde:

$$
\begin{aligned}
& X_{j}^{R} \text { é a produção total do bem } \mathrm{j} \text { na região } \mathrm{R} \\
& E_{j}^{R} \text { é o total exportado do bem } \mathrm{j} \text { pela região } \mathrm{R} \\
& M_{j}^{R} \text { é o total importado do bem } \mathrm{j} \text { pela região } \mathrm{R}
\end{aligned}
$$

Portanto, $p_{j}^{R}$ é a porcentagem da demanda total do produto $\mathrm{j}$ na região $\mathrm{R}$, atendida pela própria produção interna da região.

Pode-se construir um vetor $P$, com as porcentagens de oferta interna de cada produto na região $R$.

$$
P=\left[\begin{array}{c}
p_{1}^{R} \\
\vdots \\
p_{n}^{R}
\end{array}\right]
$$


Matriz dos coeficientes técnicos diretos para a região R:

$$
A^{R}=\hat{P} A
$$

E a inversa de Leontief:

$$
X^{R}=(I-\hat{P A})^{-1} Y^{R}
$$

A limitação destes modelos é que eles não levam em consideração as relações da região com as demais regiões produtivas, como se esta região não comprasse insumos das outras, nem tão pouco vendesse para elas.

\subsection{Modelos de insumo-produto inter-regionais (mais de uma região)}

As análises inter-regionais são desenvolvidas por meio de coeficientes de insumos intra-regionais (dentro de uma região específica) e inter-regionais (entre uma determinada região e as demais).

De acordo com Fernandes (1997), algumas das vantagens dos modelos interregionais seriam a avaliação das diferenças regionais nas estruturas técnicas de produção; avaliação dos efeitos inter-regionais resultantes de redistribuições geográficas nas atividades econômicas; estudos de balanços de pagamentos regionais e dos fluxos de comércio inter-regional; análise de impacto de variações nos programas de investimentos e ou gastos públicos sobre diferentes regiões; elaboração de planos regionais de desenvolvimento econômico e sistema de contas regionais; dentre outras.

Para melhor visualização, segue a Tabela 16 contendo os fluxos inter-setoriais e inter-regionais para duas regiões, uma com dois setores e a outra com três. 
Tabela 16. Fluxos inter-setoriais e inter-regionais para as regiões L e M.

\begin{tabular}{|c|c|c|c|c|c|c|}
\hline \multirow{2}{*}{ Setores } & & \multicolumn{5}{|c|}{ Setores Compradores } \\
\hline & & \multicolumn{3}{|c|}{ Região L } & \multicolumn{2}{|c|}{ Região M } \\
\hline Vendec & & 1 & 2 & 3 & 1 & 2 \\
\hline \multirow{3}{*}{$\begin{array}{l}\text { Região } \\
\mathrm{L}\end{array}$} & 1 & $Z_{211}^{L L}$ & $z_{12}^{L L}$ & $z_{113}^{L L}$ & $z_{111}^{L M}$ & $z_{12}^{L M}$ \\
\hline & 2 & $z_{21}^{L L}$ & $z_{22}^{L L}$ & $z, 23$ & $z_{21}^{L M}$ & $z_{22}^{L M}$ \\
\hline & 3 & $z_{31}^{L L}$ & $z_{32}^{L L}$ & $z_{33}^{L L}$ & $z_{31}^{L M}$ & $z_{32}^{L M}$ \\
\hline \multirow{2}{*}{$\begin{array}{l}\text { Região } \\
\text { M }\end{array}$} & 1 & $z_{111}^{M L}$ & $z_{12}^{M L}$ & $z^{M L}$ & $z_{111}^{M M}$ & $z_{12}^{M M}$ \\
\hline & 2 & $z_{21}^{M L}$ & $z_{22}^{M L}$ & $z_{23}^{M L}$ & $z_{21}^{M M}$ & $z_{222}^{M M}$ \\
\hline
\end{tabular}

Fonte: Miller \& Blair (1985)

Onde:

$z_{i j}^{L L}$ representa o fluxo monetário do setor i para o setor j dentro da região L.

$z_{i j}^{L M}$ e $z_{i j}^{M L}$ representam os fluxos monetários do setor i para o setor $\mathrm{j}$, da região

$L$ para a região $M$ e da região $M$ para a região $L$, respectivamente.

$z_{i j}^{M M}$ representa o fluxo monetário do setor i para o setor j dentro da região $\mathrm{M}$.

Aplicando a equação básica de produção setorial:

$X_{1}^{L}=z_{11}^{L L}+z_{12}^{L L}+z_{13}^{L L}+z_{11}^{L M}+z_{12}^{L M}+Y_{1}^{L}$

Pode-se construir equações similares para os outros setores desta e da outra região.

Considerando os coeficientes de insumo ou coeficientes intra-regionais:
$a_{i j}^{L L}=z_{i j}^{L L} / X_{j}^{L}$
$z_{i j}^{L L}=a_{i j}^{L L} X_{j}^{L}$
$a_{i j}^{M M}=z_{i j}^{M M} / X_{j}^{M}$
$z_{i j}^{M M}=a_{i j}^{M M} X_{j}^{M}$

E os coeficientes inter-regionais:
$a_{i j}^{L M}=z_{i j}^{L M} / X_{j}^{M}$
$z_{i j}^{L M}=a_{i j}^{L M} X_{j}^{M}$ 
$a_{i j}^{M L}=z_{i j}^{M L} / X_{j}^{L} \quad z_{i j}^{M L}=a_{i j}^{M L} X_{j}^{L}$

Substituindo os coeficientes acima em (11):

$X_{1}^{L}=a_{11}^{L L} X_{1}^{L}+a_{12}^{L L} X_{2}^{L}+a_{13}^{L L} X_{3}^{L}+a_{11}^{L M} X_{1}^{M}+a_{12}^{L M} X_{2}^{M}+Y_{1}^{L}$

Obtém-se a produção total do setor 1 pertencente àregião L

As produções para os demais setores também podem ser obtidas.

Isolando $Y_{1}^{L}$ e colocando $X_{1}^{L}$ em evidência:

$\left(1-a_{11}^{L L}\right)_{1}^{L}-a_{12}^{L L} X_{2}^{L}-a_{13}^{L L} X_{3}^{L}-a_{11}^{L M} X_{1}^{M}-a_{12}^{L M} X_{2}^{M}=Y_{1}^{L}$

Obtém-se a demanda final da produção do setor 1 pertencente àregião $\mathrm{L}$ As demandas finais para os outros setores também podem ser obtidas. Pode-se construir a matriz $A^{L L}$ para os três setores:

$$
A^{L L}=\left[\begin{array}{lll}
a_{11}^{L L} & a_{12}^{L L} & a_{13}^{L L} \\
a_{21}^{L L} & a_{22}^{L L} & a_{23}^{L L} \\
a_{31}^{L L} & a_{32}^{L L} & a_{33}^{L L}
\end{array}\right]
$$

Esta matriz também pode ser construída para : $A^{L M}, A^{M L}$ e $A^{M M}$.

Desta forma, define-se as seguintes matrizes:

$$
A=\left[\begin{array}{ccc}
A^{L L} & \vdots & A^{L M} \\
\cdots & \cdots & \cdots \\
A^{M L} & \vdots & A^{M M}
\end{array}\right]
$$

$$
X=\left[\begin{array}{c}
X^{L} \\
\cdots \\
X^{M}
\end{array}\right]
$$$$
Y=\left[\begin{array}{c}
Y^{L} \\
\cdots \\
Y^{M}
\end{array}\right]
$$

O sistema inter-regional completo de insumo-produto continua sendo representado, de maneira sintética, pela seguinte fórmula:

$$
(I-A) X=Y
$$


As matrizes podem ser dispostas da seguinte maneira:

$$
\left\{\left[\begin{array}{ccc}
I & \vdots & 0 \\
\cdots & \cdots & \cdots \\
0 & \vdots & I
\end{array}\right]-\left[\begin{array}{ccc}
A^{L L} & \vdots & A^{L M} \\
\cdots & \cdots & \cdots \\
A^{M L} & \vdots & A^{M M}
\end{array}\right]\right\}\left[\begin{array}{c}
X^{L} \\
\cdots \\
X^{M}
\end{array}\right]=\left[\begin{array}{c}
Y^{L} \\
\cdots \\
Y^{M}
\end{array}\right]
$$

Efetuando-se estas operações:

$$
\begin{aligned}
& \left(I-A^{L L}\right) X^{L}-A^{L M} X^{M}=Y^{L} \\
& -A^{M L} X^{M}+\left(I-A^{M M}\right) X^{M}=Y^{M}
\end{aligned}
$$

Estes são os modelos básicos necessários àanálise inter-regional.

Entretanto, o modelo inter-regional de insumo-produto, requer uma grande e diversificada quantidade de dados, e sua principal dificuldade está justamente na indisponibilidade de informações sobre o fluxo de mercadorias entre os setores e entre as regiões, pois os gastos com coleta de dados estatísticos são bastante elevados. Conseqüentemente, isso tem gerado uma grande quantidade de modelos matemáticos para estimar os fluxos de mercadorias inter-regionais a partir de métodos parcialmente censitários, ou seja, com parte das informações levantadas diretamente na região de interesse e parte estimada a partir de métodos matemáticos apropriados.

\subsubsection{Métodos de análise da estrutura produtiva}

O modelo inicialmente desenvolvido por Leontief, além de poder ser utilizado para diversas finalidades, dentre elas o impacto de políticas econômicas e a distribuição de renda e meio ambiente, é também utilizado para a análise setorial, na determinação de indicadores econômicos importantes para avaliar a importância e o impacto das 
transformações dos diversos setores produtivos da economia em termos de geração de produção, renda, salários, empregos e outras variáveis importantes.

Guilhoto et al. (1994) afirmam que apesar de haver um consenso a respeito da importância das ligações interindustriais de uma economia na determinação de estímulos ao crescimento econômico, parece haver bastante contradição no que diz respeito à identificação de setores-chave ou pólos de crescimento, confusão esta originada na dificuldade de identificação de quais seriam os setores que contribuem acima da média para a economia, tanto numa perspectiva ex-post quanto ex-ante. Entretanto, parece haver um consenso de que o processo de transformação econômica é freqüentemente estimulado por um número relativamente pequeno de setores, mesmo a economia como um todo sofrendo mudanças. Neste mesmo artigo, mostraram que diferentes índices de ligações devem ser analisados como complementares ao invés de um sendo superior ao outro.

\subsubsection{1 Índices ligações intersetoriais e setores-chave}

\subsection{1 Índices de Rasmussen-Hirschman}

Os índices de ligações de Rasmussen-Hirschman foram idealizados por Rasmussen (1956) e posteriormente desenvolvidos por Hirschman (1958) para a identificação de setores-chave na economia.

Os valores calculados para os índices de ligações para trás indicam quanto o setor demanda de outros setores da economia, enquanto os índices de ligações para frente mostram o quanto o setor é demandado pelas outras indústrias. Valores maiores do que um tanto dos índices de ligações para trás como para frente, indicam setores acima da média e, portanto, considerados setores chave para o crescimento da economia. Mas de acordo com McGilvray (1977), devem ser considerados setores-chave apenas aqueles que apresentarem tanto os índices de ligações para frente quanto os índices de ligações para trás maiores do que um. 
Para o cálculo destes índices define-se $b_{i j}$ como sendo um elemento da matriz inversa de Leontief $B ; B^{*}$ como sendo a média de todos os elementos de $B$ e $B_{*_{j}} ; B_{i^{*}}$ como sendo, respectivamente, a soma de uma coluna e de uma linha típica de $B$. Assim:

$$
\begin{aligned}
& U_{j}=\left[B_{*_{j}} / n\right] / B^{*} \\
& \text { define os índices de ligações para trás (poder de dispersão) } \\
& \text { e } \\
& U_{j}=\left[B_{i^{*}} / n\right] / B^{*} \\
& \text { define os índices de ligações para frente (sensibilidade da dispersão) }
\end{aligned}
$$

\subsection{2 Índices puros de ligações: modelo GHS}

Visto que os índices de ligações de Hasmussen-Hirschman não levam em consideração os níveis de produção de cada setor analisado, baseado nas tentativas de resolver ou minimizar esta deficiência, realizadas por Cella (1984) e Clements (1990); Guilhoto, Sonis e Hewings (1996), desenvolveram um importante trabalho, que consistiu basicamente na integração das principais técnicas utilizadas na análise de estruturas de insumo-produto, objetivando decompor e distinguir o impacto de um setor/região na economia, sobre seus vários componentes.

O trabalho visa medir a importância de um dado setor para a economia em termos de valor da produção gerado por este, corrigindo um erro de decomposição de Cella (1984) e Clements (1990) e aprimorando uma versão inicial do índice puro de ligações apresentado por Guilhoto et al. (1994).

Trata de dois enfoques, criados para propósitos diferentes: o enfoque de setores-chave, iniciado com os índices de ligações de Rasmussen-Hirschman e o enfoque de ligações puras, identificado com as fontes de mudança na economia e os efeitos internos e externos dos multiplicadores de Miyazawa (1976). O primeiro determina os impactos isolados de um setor no restante da economia e o segundo tem o 
propósito de determinar as fontes de variações na economia e o papel das ligações internas e externas aos setores considerados no desenvolvimento destas variações.

Baseado em Guilhoto et al. (1996), o cálculo dos índices puros de ligação parte da decomposição de uma matriz A, que contém os coeficientes de insumos diretos do setor destacado $j$ e o resto da economia:

$$
A=\left[\begin{array}{cc}
A_{j j} & A_{j r} \\
A_{r j} & A_{r r}
\end{array}\right]=\left[\begin{array}{cc}
A_{j j} & A_{j r} \\
A_{r j} & 0
\end{array}\right]+\left[\begin{array}{cc}
0 & 0 \\
0 & A_{r r}
\end{array}\right]=A_{j}+A_{r}
$$

Onde $A_{j j}$ e $A_{r r}$ são respectivamente matrizes que representam insumos diretos do setor $j$ e do resto da economia; $A_{r j}$ e $A_{j r}$ representam matrizes dos insumos diretos comprados pelo setor $j$ do resto da economia e os insumos diretos comprados pelo resto da economia do setor $j$. A matriz $A_{j}$ representa o setor $j$ isolado do resto da economia e a matriz $A_{r}$ representa o resto da economia.

Partindo da equação acima chega-se a:

$$
B=(I-A)^{-1}=\left[\begin{array}{ll}
B_{j j} & B_{j r} \\
B_{r j} & B_{r r}
\end{array}\right]=\left[\begin{array}{cc}
\Delta_{j j} & 0 \\
0 & \Delta_{r r}
\end{array}\right]\left[\begin{array}{cc}
\Delta_{j} & 0 \\
0 & \Delta_{r}
\end{array}\right]\left[\begin{array}{cc}
I & A_{j r} \Delta_{r} \\
A_{r j} \Delta_{j} & I
\end{array}\right]
$$

onde

$$
\begin{aligned}
& \Delta_{j}=\left(I-A_{j j}\right)^{-1} \\
& \Delta_{r}=\left(I-A_{r r}\right)^{-1} \\
& \Delta_{j j}=\left(I-\Delta_{j} A_{j r} \Delta_{r} A_{r j}\right)^{-1} \\
& \Delta_{r r}=\left(I-\Delta_{r} A_{r j} \Delta_{j} A_{j r}\right)^{-1}
\end{aligned}
$$

A partir da equação 22, juntamente com a equação $X=(I-A)^{-1} Y$, é possível verificar como ocorre o processo de produção na economia, bem como derivar uma série de índices que permitem ordenar as regiões em termos de sua importância no valor da 
produção gerada, da seguinte forma:

$$
\left[\begin{array}{l}
X_{j} \\
X_{r}
\end{array}\right]=\left[\begin{array}{cc}
\Delta_{j j} & 0 \\
0 & \Delta_{r r}
\end{array}\right]\left[\begin{array}{cc}
\Delta_{j} & 0 \\
0 & \Delta_{r}
\end{array}\right]\left[\begin{array}{cc}
I & A_{j r^{\Delta}}{ }_{r} \\
A_{r j} \Delta_{j} & I
\end{array}\right]\left[\begin{array}{l}
Y_{j} \\
Y_{r}
\end{array}\right]
$$

Multiplicando-se os três últimos termos:

$$
\left[\begin{array}{c}
X_{j} \\
X_{r}
\end{array}\right]=\left[\begin{array}{cc}
\Delta_{j j} & 0 \\
0 & \Delta_{r r}
\end{array}\right]\left[\begin{array}{c}
\Delta_{j} Y_{j}+\Delta_{j} A_{j r} \Delta_{r} Y_{r} \\
\Delta_{r} A_{r j} \Delta_{j} Y_{j}+\Delta_{r} Y_{r}
\end{array}\right]
$$

Onde as novas definições para os índices de ligações para trás e para frente serão dadas por:

$$
P B L=\Delta_{r} A_{r j} \Delta_{j} Y_{j}
$$

$P F L=\Delta_{j} A_{j r} \Delta_{r} Y_{r}$

O PBL indicará o impacto puro sobre o resto da economia do valor da produção total na região j. Impacto puro porque, segundo Guilhoto, Sonis e Hewings (1996), ele está livre: (a) da demanda de insumos que a região j produz para a região j; (b) dos retornos do resto da economia para a região j e vice versa. Por sua vez, o $P F L$ indicará o impacto puro sobre a região j, do valor da produção total no resto da economia $\mathrm{r}$.

Para saber qual é o índice puro do total das ligações ( $P T L$ ) de cada setor na economia, é possível adicionar o $P B L$ ao $P F L$, visto que estes índices, são expressos em valores correntes.

$$
P T L=P B L+P F L
$$

Também é possível calcular os índices puros de ligações normalizados, dividindo-se os índices puros pelo seu valor médio. O índice puro de ligação normalizado para trás é representado por PBLN: 


$$
P B L N=\frac{P B L}{P B L m}
$$

PBLm representa a média dos índices puros de ligação de todos os setores, e é dada por:

$$
P B L m=\frac{\sum_{i=1}^{n} P B L_{i}}{n}
$$

Procedimento análogo é realizado para calcular o índice puro normalizado para frente $(P F L N)$ e o índice puro total de ligação normalizado (PTLN)

\subsection{Campo de influência}

Uma das críticas aos índices de ligações é que, apesar de possibilitarem uma avaliação do poder de encadeamento de cada setor dentro da economia, não permitem determinar os principais elos de ligação, ou seja, as relações entre setores mais importantes dentro da economia cujas variações dos coeficientes teriam maiores impactos sobre o sistema. Isso pelo fato de não levarem em consideração os diferentes níveis de produção em cada setor da economia, o que explica a necessidade de serem complementados pelo método do campo de influência proposto por Sonis e Hewings (1989).

Este método permite verificar como se distribuem as mudanças dos coeficientes diretos no sistema econômico como um todo, possibilitando, desse modo, determinar quais relações nos setores são mais importantes dentro do processo produtivo.

Para seu cálculo utiliza-se a matriz de coeficientes técnicos de produção $A=\left|a_{i j}\right|$ e a matriz de variações incrementais nos coeficientes diretos de insumo, $E=\left|\varepsilon_{\mathrm{ij}}\right|$. As matrizes inversas de Leontief são $B=(I-A)^{-1}$ e $B=(I-A+\varepsilon)^{-1}$, cujos coeficientes são $b_{i j}$ e $b_{i j}(\varepsilon)$, respectivamente. De acordo com Sonis e Hewings (1989), caso a variação seja pequena e só ocorra num coeficiente direto, isto é: 


$$
\varepsilon_{i j}= \begin{cases}\varepsilon & i=i_{1}, j=j_{1} \\ 0 & i \neq i_{1} \text { ou } j \neq j_{1}\end{cases}
$$

O campo de influência desta variação pode ser aproximado pela expressão:

$$
F\left(\varepsilon_{i j}\right)=\frac{\left|B\left(\varepsilon_{i j}\right)-B\right|}{\varepsilon_{i j}}
$$

em que $F\left(\varepsilon_{i j}\right)$ é a matriz ( $n \times n$ ) do campo de influência do coeficiente $a_{i j}$.

Para determinar quais coeficientes possuem o maior campo de influência, associa-se a cada matriz $\mathrm{F}\left(\varepsilon_{\mathrm{ij}}\right)$ um valor que é dado por:

$$
S_{i j}=\sum_{k=1 l=1}^{n} \sum_{l=1}^{n}\left[f_{k l}\left(\varepsilon_{i j}\right)\right]^{2}
$$

Portanto, os setores-chave da economia são aqueles que possuem os maiores coeficientes $S_{\mathrm{ij}}$, ou seja, os maiores campos de influência.

\subsection{Multiplicadores}

Os multiplicadores insumo-produto são medidas derivadas dos elementos da inversa de Leontief $(I-A)^{-1}$, frequentemente empregados em análises de impacto econômico. Podem ser examinados tanto no contexto nacional quanto no regional.

Discussões introdutórias em multiplicadores em modelos insumo-produto podem ser encontradas, entre outros, em Miernyk (1965), Richardson (1972) e Schaffer (1976). Discussões mais recentes com problemas com algumas definições convencionais dos multiplicadores, e possíveis inconscistências podem ser encontradas, por exemplo, em Jensen (1978), West e Jensen (1980) e Jensen e West (1980). Em se tratando de um contexto regional, pode-se encontrar discussões de multiplicadores completamente em modelos multirregionais em DiPasquale e Polenske (1980). 
Seu cálculo nos permite analisar o impacto de uma variação na demanda final de determinado setor sobre a variável econômica de interesse.

Os três tipos de multiplicadores mais frequentemente utilizados são aqueles que estimam os efeitos das mudanças exógenas na produção de setores na economia, na renda ganha pelos consumidores domésticos por causa da nova produção e no emprego (em termos físicos) esperado de ser gerado devido ànova produção.

Os multiplicadores podem ser encontrados considerando o consumo doméstico das famílias exógenamente, e neste caso são chamados de multiplicadores do tipo I. Aqueles obtidos a partir de modelos que consideram o consumo doméstico das famílias endogenamente são conhecidos como multiplicadores do tipo II, onde a matriz Z (transações intersetoriais), segundo Miller \& Blair (1985), incorpora uma linha e uma coluna adicionais correspondentes àremuneração das famílias e ao consumo doméstico.

Enquanto os multiplicadores do tipo I incluem apenas os efeitos diretos (sobre o próprio setor) e indiretos (sobre os demais setores), os multiplicadores do tipo II incluem efeitos diretos, indiretos e induzidos (via consumo endogeneizado) de um aumento unitário na demanda final do setor que se deseja avaliar o impacto sobre a economia.

\subsection{Multiplicadores da produção}

É a produção adicional gerada em toda a economia, decorrente de uma alteração na demanda final de um determinado setor.

Denotando os elementos da matriz $B=(I-A)^{-1}$ por $b_{i j}$, temos o multiplicador tipo I:

$$
M P_{j}=\sum_{i=1}^{n} b_{i j}
$$

onde $j$ representa um determinado setor da economia.

Para o multiplicador tipo II, calcula-se a matriz inversa de Leontief $\bar{B}=(I-\bar{A})^{-1}$, cujos coeficientes são $\bar{b}_{i j}$, e é obtida a partir de uma matriz $\bar{A}$ de coeficientes técnicos, onde o consumo das famílias é endogeneizado. 


$$
M \bar{P}_{j}=\sum_{i=1}^{n} \bar{b}_{i j}
$$

\subsection{Multiplicadores da renda}

Os multiplicadores de renda permitem quantificar a renda gerada, em todos os setores, para cada unidade monetária de renda obtida em um determinado setor devido ao seu aumento de produção necessário para atender a variação em uma unidade de sua demanda final.

Algebricamente, tem-se o multiplicador tipo I:

$$
M R_{j}=\sum_{i=1}^{n}\left(a_{n+1, i} b_{i j}\right) / a_{n+1, j}
$$

onde:

$a_{n+1, i}$ corresponde aos elementos da linha dos coeficientes de remuneração das famílias

$b_{i j}$ representa os elementos da inversa de Leontief sem a endogeneização do consumo doméstico das famílias.

E o multiplicador do tipo II:

$$
M \bar{R}_{j}=\sum_{i=1}^{n}\left(a_{n+1, i} \bar{b}_{i j}\right) / a_{n+1, j}
$$

onde:

$a_{n+1, i}$ corresponde aos elementos da linha dos coeficientes de remuneração das famílias

$\overline{b_{i j}}$ representa os elementos da inversa de Leontief, considerando o consumo doméstico das famílias endogenamente. 


\subsection{Multiplicadores do emprego}

Os multiplicadores do emprego permitem determinar o número de empregos gerados na economia como um todo, para cada emprego gerado no setor de interesse, ou seja, quantos empregos indiretos são gerados para cada emprego direto gerado.

Embora juntamente analisados na economia, os multiplicadores do emprego de cada setor não devem ser confundidos com o gerador de empregos de cada setor. Estes últimos dizem o quanto de emprego é gerado dentro de cada setor, ao atender à sua demanda final em uma unidade.

O multiplicador de emprego tipo I para um determinado setor j é dado por:

$$
M E_{j}=\sum_{i=1}^{n}\left(w_{n+1, i} b_{i j}\right) / w_{n+1, j}
$$

onde:

$w_{n+1}$ é o número de empregos gerados por unidade monetária produzida

$b_{i j}$ representa os elementos da Inversa de Leontief sem a endogeneização do consumo doméstico das famílias.

O multiplicador de emprego tipo II:

$$
M \bar{E}_{j}=\sum_{i=1}^{n}\left(w_{n+1, i} \bar{b}_{i j}\right) / w_{n+1, j}
$$

onde:

$w_{n+1}$ é o número de empregos gerados por unidade produzida

$b_{i j}$ representa os elementos da Inversa de Leontief, considerando o consumo doméstico das famílias endogenamente. 


\subsection{Fonte de dados e procedimentos adotados}

O instrumental teórico utilizado para a realização deste estudo foi o Modelo Insumo-Produto, desenvolvido por Wassily Leontief, em 1930. Especificamente, utilizou-se um modelo Insumo-Produto inter-regional para mais de uma região (no caso duas), estimado a partir de métodos parcialmente censitários.

Deve-se ressaltar que este trabalho é fruto de um projeto realizado em equipe, visando atender além de um estudo detalhado da economia brasileira, diversos interesses de pesquisas específicas.

Estimou-se a matriz inter-regional do Mato Grosso e resto do Brasil para o ano de 1999 (em 90 setores), a partir da matriz inter-regional dos estados da Amazônia Legal $^{9}$ e resto do Brasil (em 90 setores), estimada pela equipe "Projeções Econômicas" coordenada pelo professor Joaquim José Martins Guilhoto. Esta matriz para os estados da Amazônia Legal foi obtida a partir da matriz nacional (em 90 setores) para 1999, desagregada da matriz nacional (em 42 setores) para o mesmo ano, que por sua vez foi estimada a partir dos dados preliminares das Contas Nacionais para 1999, de acordo com metodologia desenvolvida por Guilhoto et al.(2002).

Uma vez obtida, a matriz inter-regional Mato Grosso x Resto do Brasil foi agregada para 51 setores, de modo que para atender os objetivos específicos do trabalho, não há necessidade em se trabalhar com 90 setores produtivos. O critério utilizado foi o de seguir a classificação oficial do IBGE, porém agregando alguns setores de pouca relevância tanto para a economia do estado quanto para os interesses da pesquisa, e desagregando alguns diretamente relacionados a agropecuária. O Quadro 3 apresenta os setores com suas numerações de acordo com a classificação oficial do IBGE, e suas respectivas agregações e desagregações de modo a atingir os 51 setores utilizados no trabalho.

\footnotetext{
${ }^{9}$ Estados da Amazônia Legal: AC, AP, AM, PA, RO, RR, TO, MA e MT.
} 


\begin{tabular}{|c|c|c|c|}
\hline $\begin{array}{l}\text { Numeração } \\
\text { IBGE }\end{array}$ & $\begin{array}{l}\text { Classificação } \\
\text { IBGE }\end{array}$ & $\begin{array}{c}\text { Numeração } \\
\text { Pesquisa }\end{array}$ & $\begin{array}{c}\text { Classificação } \\
\text { Pesquisa }\end{array}$ \\
\hline \multirow[t]{12}{*}{1} & \multirow[t]{12}{*}{ Agropecuária } & 1 & Cana-de-açúcar \\
\hline & & 2 & Soja \\
\hline & & 3 & Milho \\
\hline & & 4 & Fruticultura \\
\hline & & 5 & Outras Culturas \\
\hline & & 6 & Aves \\
\hline & & 7 & Bovinos \\
\hline & & 8 & Suínos \\
\hline & & 9 & Outros Pecuária \\
\hline & & 10 & Extrativismo Vegetal \\
\hline & & 11 & Silvicultura \\
\hline & & 12 & Extrativismo Animal (Pesca) \\
\hline 2 & Extrativismo Mineral & \multirow[t]{3}{*}{13} & \multirow[t]{3}{*}{ Extartivismo Mineral } \\
\hline 3 & Petróleo e Gás & & \\
\hline 4 & Minerais não metálicos & & \\
\hline 5 & Siderurgia & \multirow[t]{3}{*}{14} & \multirow[t]{3}{*}{ Siderurgia } \\
\hline 6 & Metalúrgicos não ferrosos & & \\
\hline 7 & Outros metalúrgicos & & \\
\hline \multirow[t]{2}{*}{8} & \multirow[t]{2}{*}{ Máquinas e equipamentos } & 15 & Máquinas e implementos agrícolas \\
\hline & & 16 & Outras máquinas e equipamentos \\
\hline 10 & Material elétrico & \multirow[t]{2}{*}{17} & \multirow[t]{2}{*}{ Eletro-eletrônicos } \\
\hline 11 & Equipamentos eletrônicos & & \\
\hline 12 & Automóveis., caminhões e ônibus & \multirow[t]{2}{*}{18} & \multirow[t]{2}{*}{ Peças e veículos } \\
\hline 13 & Peças e outros veículos & & \\
\hline 14 & Madeira e mobiliário & 19 & Madeira e mobiliário \\
\hline 15 & Celulose, papel e gráfica & 20 & Celulose, papel e gráfica \\
\hline 16 & Indústria da borracha & \multirow{4}{*}{$\begin{array}{l}21 \\
24\end{array}$} & \multirow{4}{*}{$\begin{array}{l}\text { Químicos diversos } \\
\text { Adubos e fertilizantes }\end{array}$} \\
\hline 17 & Elementos químicos & & \\
\hline 19 & Químicos diversos & & \\
\hline 21 & Artigos plásticos & & \\
\hline 18 & Refino do petróleo & 23 & Refino do petróleo \\
\hline 20 & Farmácia e veterinária & 25 & Farmácia e veterinária \\
\hline 22 & Indústria têxtil & 26 & Indústria têxtil e calçadista \\
\hline 23 & Artigos do vestuário & & \\
\hline 24 & Fabricação de calçados & & \\
\hline 25 & Indústria do café & 27 & Indústria do café \\
\hline 26 & Beneficiamento de produtos vegetais & 28 & Beneficiamento de produtos vegetais \\
\hline \multirow[t]{2}{*}{27} & \multirow[t]{2}{*}{ Abate de animais } & 29 & Abate de outros animais \\
\hline & & 30 & Abate de bovinos \\
\hline 28 & Indústria de laticínios & 31 & Indústria de laticínios \\
\hline 29 & Fabricação de açúcar & 32 & Fabricação de açúcar \\
\hline 30 & Fabricação de óleos vegetais & 33 & Fabricação de óleos vegetais \\
\hline \multirow[t]{2}{*}{31} & Outros produtos alimentares & 34 & Rações \\
\hline & & 35 & Outros produtos alimentares \\
\hline 32 & Indústrias diversas & 36 & Indústrias diversas \\
\hline 33 & S.I.U.P. & 37 & S.I.U.P. \\
\hline 34 & Construção civil & 38 & Construção civil \\
\hline 35 & Comércio & 39 & Comércio \\
\hline 36 & Transportes & 40 & Transporte rodoviário \\
\hline & & 41 & Transporte aéreo \\
\hline & & 42 & Transporte ferroviário \\
\hline & & 43 & Transporte aquaviário \\
\hline & & 44 & Atividades auxiliares dos transportes \\
\hline 37 & Comunicações & 45 & Comunicações \\
\hline 38 & Instituições financeiras & 46 & Instituições financeiras \\
\hline 39 & Serviços prestados às famílias & 47 & Serviços prestados às famílias \\
\hline 40 & Serviços prestados às empresas & 48 & Serviços prestados às empresas \\
\hline 41 & Aluguel de imóveis & 49 & Aluguel de imóveis \\
\hline 42 & Administração pública & 50 & Administração pública \\
\hline 43 & Serviços privados não mercantis & 51 & Serviços privados não mercantis \\
\hline
\end{tabular}

Quadro 4 - Comparação entre a classificação de setores do IBGE e a utilizada no trabalho.

Fonte: Construída pela autora baseado na classificação setorial oficial do IBGE. 
Em seguida, calculou-se os multiplicadores tipos I e II para o emprego, renda e produção, bem como os índices de ligação Hirschman-Rasmussen, os coeficientes do campo de influência e os índices puros de ligação, de acordo com as definições presentes no referencial teórico.

Calculou-se também qual o impacto das exportações totais do Mato Grosso, bem como das exportações de soja do estado, e de um acréscimo em 10\% nestas últimas exportações, sobre a produção total, valor adicionado e geração de empregos em toda a economia, além do efeito sobre a produção dos setores Transporte rodoviário (40) e Transporte ferroviário (42), em ambas as regiões, ao atender a demanda final de cada um dos setores pertencentes ao Mato Grosso.

Finalmente, calculou-se o PIB do agronegócio da soja no Mato Grosso, como descrito a seguir:

\section{Produto Interno Bruto do agronegócio da soja no Mato Grosso}

Seguindo a proposta de Furtuoso et al. (1998) e detalhada em Guilhoto et al. (2000), o procedimento utilizado para a estimativa do PIB do Agronegócio da soja no Mato Grosso utilizou as informações disponíveis na Matriz Insumo-Produto, referentes aos componentes do complexo Agroindustrial da soja.

O Complexo do Agronegócio da soja é composto, além do setor da Soja (2), dos setores industriais que apresentam as maiores interligações com o mesmo, as quais foram verificadas a partir análise das principais vendas do setor da soja e principais compras das agroindústrias presentes no sistema.

O valor total do PIB do Agronegócio da soja no Mato Grosso é dividido em: a) insumos; b) o próprio setor; c) processamento; e d) distribuição e serviços.

$\mathrm{O}$ procedimento adotado para a estimativa do PIB se dá pelo enfoque do Produto, ou seja, do cálculo do Valor Adicionado a preços de mercado.

Assim, tem-se que o Valor Adicionado a preços de mercado foi obtido pela soma do valor adicionado a preços básicos aos impostos indiretos líquidos de subsídios sobre produtos e subtração da dummy financeira, resultando na seguinte expressão: 


$$
V A_{P M}=V A_{P B}+I I L-D u F
$$

onde:

$V A_{P M}=$ Valor Adicionado a Preços de Mercado

$V A_{P B}=$ Valor Adicionado a Preços Básicos

$I I L=$ Impostos Indiretos Líquidos

$D u F=$ Dummy Financeiro

Para o cálculo do PIB do Agregado I (insumos não agropecuários para a lavoura) foram utilizadas as informações disponíveis na matriz referentes aos valores dos insumos adquiridos pelo setor da Soja (2). As colunas com os valores dos insumos foram multiplicadas pelos respectivos coeficientes de valor adicionado $\left(C V A_{i}\right)$. Para obter-se os Coeficientes do Valor Adicionado por setor $\left(C V A_{i}\right)$ dividiu-se o Valor Adicionado a Preços de Mercado $\left(V A_{P M_{i}}\right)$ pela Produção do Setor $\left(X_{i}\right)$, ou seja,

$$
C V A_{i}=\frac{V A_{P M_{i}}}{X_{i}}
$$

Desta forma, eliminou-se o problema de dupla contagem, gerado quando se leva em consideração os valores dos insumos e não o valor adicionado efetivamente gerado na produção destes. Tem-se então:

$$
P I B_{I}=\sum_{i=1}^{n} Z_{i}^{*} C V A_{i}
$$

$i=$ não inclui os setores agropecuários ( $n$ setores fornecedores de insumos)

$P I B_{I}=$ PIB do agregado I (insumos não agropecuários)

$Z_{i}=$ valor total do insumo do setor $i$ para a soja

$C V A_{i}=$ coeficiente de valor adicionado do setor $i$

Para o Agregado II (Soja) considerou-se no cálculo os valores adicionados gerados pelo próprio setor. Então:

$$
P I B_{I I}=V A_{P M}
$$

onde:

$$
P I B_{I I}=\text { PIB do agregado II para soja }
$$


O Agregado III (Agroindústrias), ficou constituído pelas seguintes atividades:

$>\quad$ Beneficiamento de produtos vegetais;

$>\quad$ Fabricação de óleos vegetais;

$>$ Rações;

$>$ Outros produtos alimentares;

Os Agregados II e III, portanto, expressam a renda ou o valor adicionado gerado por esses segmentos.

No caso da estimação do Agregado III (Agroindústrias) adotou-se o somatório dos valores adicionados pelos setores agroindustriais subtraídos dos valores adicionados destes setores que foram utilizados como insumos do Agregado II. Esta subtração visa a eliminação da dupla contagem.

$$
P I B_{I I I}=\sum\left(V A_{P M_{q}}-z_{q}^{*} C V A_{q}\right)
$$

onde:

$$
P I B_{I I I}=P I B \text { do agregado III }
$$

No caso do Agregado IV, referente à Distribuição Final, considerou -se para fins de cálculo o valor agregado dos setores relativos ao Transporte, Comércio e segmentos de Serviços. Do valor total obtido destinou-se ao Agronegócio da soja apenas a parcela que corresponde àparticipação da soja e agroindústria na demanda final de produtos. A sistemática adotada no cálculo do valor da distribuição final do agronegócio da soja pode ser representada por:

$$
\begin{gathered}
D F G-I I L_{D F}-P I_{D F}=D F D \\
V A T_{P M}+V A C_{P M}+V A S_{P M}=M C \\
P I B_{I V}=M C * \frac{D F+\sum D F_{q}}{D F D}
\end{gathered}
$$

onde:

$D F G=$ demanda final global

$I I L_{D F}=$ impostos indiretos líquidos pagos pela demanda final 
$P I_{D F}=$ produtos importados pela demanda final

$D F D=$ demanda final doméstica

$V A T_{P M}=$ valor adicionado do setor transporte a preços de mercado

$V A C_{P M}=$ valor adicionado do setor comércio a preços de mercado

$V A S_{P M}=$ valor adicionado do setor serviços a preços de mercado

$M C$ =margem de comercialização

$D F=$ demanda final da soja

$D F_{q}=$ demanda final dos setores agroindustriais

$P I B_{I V}=$ PIB do agregado IV

O PIB total do Agronegócio da soja foi dado pela soma dos seus agregados, ou seja:

$P I B_{\text {Agronegóciosoja }}=P I B_{I}+P I B_{I I}+P I B_{I I I}+P I B_{I V}$

onde:

$P I B_{\text {Agronegóciosoja }}=$ PIB do agronegócio da soja no Mato Grosso 


\section{RESULTADOS E DISCUSSÃO}

Os resultados da pesquisa são constituídos dos valores dos indicadores econômicos conforme salientados nos objetivos, e detalhados no referencial teórico, os quais foram obtidos utilizando-se a matriz insumo-produto inter-regional para o Mato Grosso e resto do Brasil, referente ao ano de 1999.

\section{1 Índices de ligações intersetoriais}

Os índices de Rasmussen-Hirschman e os índices puros de ligações normalizados foram calculados para a identificação dos setores-chave ou pólos de desenvolvimento das economias do Mato Grosso e resto do Brasil no ano de 1999. Os valores apresentados são relativos à média da economia, uma vez que as médias de cada série de índices são iguais a um, o que significa dizer que todos os valores maiores do que um indicam que o nível de encadeamento do setor é superior à média dos demais, e portanto, estes representam setores-chave ao desenvolvimento da região. Como o estado do Mato Grosso representa uma região da matriz, este poderá ser mencionado ao longo da análise como região Mato Grosso. 
Ao trabalhar com modelos inter-regionais, os índices de ligações podem ser obtidos através de dois procedimentos distintos, chegando-se aos índices independentes, para os quais as economias são vistas de maneira isolada, sem se levar em consideração os efeitos das interações regionais, e aos índices dependentes, cujos valores trazem os efeitos das interações regionais. Algebricamente, o índice independente se origina a partir do cálculo de uma matriz inversa de Leontief para cada região, e o dependente, por sua vez, requer a inversão da matriz $(I-A)$ para todo o sistema.

Apesar do tratamento diferenciado, verificou-se que os resultados são muito próximos e a diferença não se mostra significativa, o que justifica o fato do presente trabalho limitar-se a apresentar apenas os índices dependentes.

\subsection{1 Índices de Rasmussen-Hirschman}

As Tabelas 17 e 18 apresentam os valores calculados para os índices de Rasmussen-Hirschman para o estado do Mato Grosso e resto do Brasil, respectivamente. As Figuras 1, 2, 3 e 4 ilustram estas relações para melhor visualização dos vinte setores com os maiores valores destes índices, em cada região. Os principais setores com fortes ligações para trás, os quais dinamizam a economia ao se destacarem como importantes compradores para seus fornecedores de bens e serviços, são Eletro-eletrônicos (17), Abate de bovinos (30), Peças e veículos (18), Indústria do café (27), Adubos e fertilizantes (24), Fabricação de óleos vegetais (33), Abate de outros animais (29), Químicos diversos (21), Fabricação de açúcar (32) e Beneficiamento de produtos vegetais (28), para a região do Mato Grosso; e, Abate de outros animais (29), Abate de bovinos (30), Fabricação de óleos vegetais (33), Fabricação de açúcar (32), Indústria de laticínios (31), Adubos e fertilizantes (24), Outros produtos alimentares (35), Aves (6), Rações (34) e Indústria do café (27), para o resto do Brasil.

Já os principais setores com fortes ligações para frente, os quais dinamizam a economia ao se destacarem como importantes fornecedores de matéria-prima para os outros setores, são: Comércio (39), Serviços Industriais de Utilidade Pública - S.I.U.P. (37), Siderurgia (14), Serviços prestados à empresas (48), Outras culturas (5), 
Administração pública (50), Transporte rodoviário (40), Instituições financeiras (46), Cana-de-açúcar (1) e Comunicações (45), para a região do Mato Grosso; e, Refino do petróleo (23), Comércio (39), Siderurgia (14), Químicos diversos (21), Outras culturas (5), S.I.U.P. (37), Adubos e fertilizantes (24), Serviços prestados à empresas (48), Extrativismo mineral (13) e Celulose, papel e gráfica (20), para o resto do Brasil.

Note que setores diretamente relacionados à agropecuária, como Abate de outros animais (29), Abate de bovinos (30), Fabricação de óleos vegetais (33), Fabricação de açúcar (32), Adubos e fertilizantes (24), e Indústria do café (27) destacaram-se como importantes compradores de insumos dos demais setores tanto no Mato Grosso quanto no resto do Brasil, o que confirma empiricamente a idéia de que a agricultura tem um papel fundamental no crescimento econômico de um país em função de suas relações comerciais com os demais setores, conforme mensurado na revisão de literatura. Os setores Comércio (39), Siderurgia (14), S.I.U.P. (37) e Serviços prestados às empresas (48) estiveram entre os dez com maior poder de encadeamento para frente, ou seja, os mais demandados pelos demais setores dentro das duas regiões consideradas.

Seguindo uma abordagem mais restrita, proposta por McGilvray (1977), de que serão considerados setores-chave apenas os que apresentarem tanto o índice de ligação para frente quanto para trás maiores do que um, são identificados como tais setores no Mato Grosso a Siderurgia (14), Químicos diversos (21), Refino do Petróleo (23), Fabricação de óleos vegetais (33) e S.I.U.P. (37) e no resto do Brasil Siderurgia (14), Celulose, papel e gráfica (20), Químicos diversos (21), Refino do petróleo (23), Adubos e fertilizantes (24), Indústria têxtil e calçadista (26) e Transporte rodoviário (40).

Entretanto, deve-se lembrar, conforme discutido anteriormente, que apesar dos índices de Rasmussen-Hirschman serem amplamente utilizados na análise de setoreschave, especialmente no estudo da estrutura produtiva de cada economia, estes não levam em consideração o valor da produção total das indústrias, apontando apenas o grau de ligação de cada uma às demais, devendo, portanto, que sua análise seja complementada pelos índices puros de ligações, os quais levam em consideração o valor da produção de cada setor. 
Tabela 17. Índices de Hirschman-Rasmussen para o Mato Grosso.

\begin{tabular}{|c|c|c|c|c|c|}
\hline & & Trás & Ordem & Frente & Ordem \\
\hline 1 & Cana-de-açúcar & 0,83 & 41 & 1,25 & 9 \\
\hline 2 & Soja & 0,84 & 39 & 1,08 & 15 \\
\hline 3 & Milho & 0,89 & 32 & 1,08 & 14 \\
\hline 4 & Fruticultura & 0,83 & 40 & 0,77 & 34 \\
\hline 5 & Outras culturas & 0,80 & 46 & 1,55 & 5 \\
\hline 6 & Aves & 1,14 & 15 & 0,91 & 22 \\
\hline 7 & Bovinos & 0,81 & 44 & 1,19 & 12 \\
\hline 8 & Suínos & 0,95 & 27 & 0,86 & 27 \\
\hline 9 & Outros pecuária & 0,89 & 33 & 0,85 & 28 \\
\hline 10 & Extrativismo vegetal & 0,75 & 48 & 0,78 & 33 \\
\hline 11 & Silvicultura & 0,97 & 25 & 0,67 & 49 \\
\hline 12 & Extrativismo animal (Pesca) & 0,82 & 43 & 0,67 & 50 \\
\hline 13 & Extrativismo mineral & 0,82 & 42 & 0,88 & 26 \\
\hline 14 & Siderurgia & 1,14 & 14 & 1,75 & 3 \\
\hline 15 & Máquinas e Implementos agrícolas & 0,88 & 34 & 0,68 & 46 \\
\hline 16 & Outras máquinas e equipamentos & 1,11 & 18 & 0,71 & 43 \\
\hline 17 & Eletro-eletrônicos & 1,33 & 1 & 0,69 & 44 \\
\hline 18 & Peças e veículos & 1,31 & 3 & 0,68 & 48 \\
\hline 19 & Madeira e mobiliário & 1,01 & 23 & 0,90 & 24 \\
\hline 20 & Celulose, papel e gráfica & 1,11 & 17 & 0,75 & 39 \\
\hline 21 & Químicos diversos & 1,24 & 8 & 1,01 & 16 \\
\hline 22 & Álcool & 1,08 & 19 & 0,92 & 19 \\
\hline 23 & Refino do Petróleo & 1,08 & 20 & 1,19 & 11 \\
\hline 24 & Adubos e fertilizantes & 1,28 & 5 & 0,96 & 17 \\
\hline 25 & Farmácia e veterinária & 1,20 & 13 & 0,69 & 45 \\
\hline 26 & Indústria têxtil e calçadista & 1,02 & 22 & 0,78 & 32 \\
\hline 27 & Indústria do café & 1,29 & 4 & 0,74 & 40 \\
\hline 28 & Beneficiamento de produtos vegetais & 1,21 & 10 & 0,80 & 31 \\
\hline 29 & Abate de outros animais & 1,25 & 7 & 0,76 & 36 \\
\hline 30 & Abate de bovinos & 1,33 & 2 & 0,76 & 37 \\
\hline 31 & Indústria de laticínios & 0,69 & 51 & 0,68 & 47 \\
\hline 32 & Fabricação de açucar & 1,22 & 9 & 0,91 & 21 \\
\hline 33 & Fabricação de óleos vegetais & 1,27 & 6 & 1,14 & 13 \\
\hline 34 & Rações & 1,21 & 11 & 0,73 & 41 \\
\hline 35 & Outros produtos alimentares & 1,20 & 12 & 0,75 & 38 \\
\hline 36 & Indústrias Diversas & 1,06 & 21 & 0,72 & 42 \\
\hline 37 & S.I.U.P & 1,12 & 16 & 1,90 & 2 \\
\hline 38 & Construção civil & 0,85 & 37 & 0,85 & 29 \\
\hline 39 & Comércio & 0,97 & 26 & 3,04 & 1 \\
\hline 40 & Transporte rodoviário & 0,87 & 35 & 1,44 & 7 \\
\hline 41 & Transporte aéreo & 0,98 & 24 & 0,91 & 20 \\
\hline 42 & Transporte ferroviário & 0,90 & 31 & 0,84 & 30 \\
\hline 43 & Transporte aquaviário & 0,94 & 28 & 0,77 & 35 \\
\hline 44 & Atividades auxiliares dos transportes & 0,91 & 30 & 0,89 & 25 \\
\hline 45 & Comunicações & 0,76 & 47 & 1,23 & 10 \\
\hline 46 & Instituições financeiras & 0,93 & 29 & 1,32 & 8 \\
\hline 47 & Serviços prestados às famílias & 0,86 & 36 & 0,93 & 18 \\
\hline 48 & Serviços prestados às empresas & 0,85 & 38 & 1,57 & 4 \\
\hline 49 & Aluguel de imóveis & 0,71 & 49 & 0,90 & 23 \\
\hline 50 & Administração pública & 0,81 & 45 & 1,50 & 6 \\
\hline 51 & Serviços privados não mercantis & 0,71 & 50 & 0,67 & 51 \\
\hline
\end{tabular}


Tabela 18. Índices de Hirschman-Rasmussen para o resto do Brasil.

\begin{tabular}{|c|c|c|c|c|c|}
\hline & & Trás & Ordem & Frente & Ordem \\
\hline 1 & Cana-de-açúcar & 0,91 & 35 & 0,97 & 17 \\
\hline 2 & Soja & 1,09 & 18 & 0,80 & 24 \\
\hline 3 & Milho & 1,16 & 13 & 0,91 & 19 \\
\hline 4 & Fruticultura & 0,82 & 41 & 0,65 & 41 \\
\hline 5 & Outras culturas & 0,78 & 43 & 1,73 & 5 \\
\hline 6 & Aves & 1,18 & 8 & 0,78 & 25 \\
\hline 7 & Bovinos & 0,99 & 29 & 1,21 & 11 \\
\hline 8 & Suínos & 1,08 & 19 & 0,73 & 32 \\
\hline 9 & Outros pecuária & 0,98 & 30 & 0,72 & 33 \\
\hline 10 & Extrativismo vegetal & 0,69 & 48 & 0,62 & 45 \\
\hline 11 & Silvicultura & 0,70 & 47 & 0,61 & 48 \\
\hline 12 & Extrativismo animal (Pesca) & 0,73 & 46 & 0,54 & 50 \\
\hline 13 & Extrativismo mineral & 0,86 & 40 & 1,36 & 9 \\
\hline 14 & Siderurgia & 1,17 & 12 & 2,21 & 3 \\
\hline 15 & Máquinas e Implementos agrícolas & 0,90 & 38 & 0,57 & 49 \\
\hline 16 & Outras máquinas e equipamentos & 0,90 & 37 & 0,94 & 18 \\
\hline 17 & Eletro-eletrônicos & 1,05 & 23 & 0,71 & 34 \\
\hline 18 & Peças e veículos & 1,09 & 16 & 0,88 & 21 \\
\hline 19 & Madeira e mobiliário & 1,02 & 26 & 0,70 & 36 \\
\hline 20 & Celulose, papel e gráfica & 1,12 & 14 & 1,28 & 10 \\
\hline 21 & Químicos diversos & 1,06 & 20 & 2,13 & 4 \\
\hline 22 & Álcool & 1,06 & 21 & 0,70 & 35 \\
\hline 23 & Refino do Petróleo & 1,04 & 25 & 3,41 & 1 \\
\hline 24 & Adubos e fertilizantes & 1,22 & 6 & 1,50 & 7 \\
\hline 25 & Farmácia e veterinária & 1,01 & 28 & 0,63 & 43 \\
\hline 26 & Indústria têxtil e calçadista & 1,17 & 11 & 1,02 & 15 \\
\hline 27 & Indústria do café & 1,18 & 10 & 0,66 & 38 \\
\hline 28 & Beneficiamento de produtos vegetais & 1,09 & 17 & 0,81 & 23 \\
\hline 29 & Abate de outros animais & 1,40 & 1 & 0,61 & 47 \\
\hline 30 & Abate de bovinos & 1,35 & 2 & 0,62 & 44 \\
\hline 31 & Indústria de laticínios & 1,23 & 5 & 0,66 & 40 \\
\hline 32 & Fabricação de açúcar & 1,25 & 4 & 0,74 & 29 \\
\hline 33 & Fabricação de óleos vegetais & 1,32 & 3 & 0,90 & 20 \\
\hline 34 & Rações & 1,18 & 9 & 0,98 & 16 \\
\hline 35 & Outros produtos alimentares & 1,21 & 7 & 0,65 & 42 \\
\hline 36 & Indústrias Diversas & 1,01 & 27 & 0,66 & 39 \\
\hline 37 & S.I.U.P & 0,88 & 39 & 1,65 & 6 \\
\hline 38 & Construção civil & 0,91 & 36 & 0,69 & 37 \\
\hline 39 & Comércio & 0,96 & 31 & 2,48 & 2 \\
\hline 40 & Transporte rodoviário & 1,05 & 24 & 1,15 & 13 \\
\hline 41 & Transporte aéreo & 1,12 & 15 & 0,75 & 28 \\
\hline 42 & Transporte ferroviário & 0,94 & 32 & 0,74 & 30 \\
\hline 43 & Transporte aquaviário & 1,06 & 22 & 0,62 & 46 \\
\hline 44 & Atividades auxiliares dos transportes & 0,93 & 33 & 0,74 & 31 \\
\hline 45 & Comunicações & 0,69 & 49 & 1,03 & 14 \\
\hline 46 & Instituições financeiras & 0,77 & 44 & 1,16 & 12 \\
\hline 47 & Serviços prestados às famílias & 0,92 & 34 & 0,76 & 27 \\
\hline 48 & Serviços prestados às empresas & 0,79 & 42 & 1,49 & 8 \\
\hline 49 & Aluguel de imóveis & 0,58 & 51 & 0,77 & 26 \\
\hline 50 & Administração pública & 0,77 & 45 & 0,84 & 22 \\
\hline 51 & Serviços privados não mercantis & 0,60 & 50 & 0,54 & 51 \\
\hline
\end{tabular}




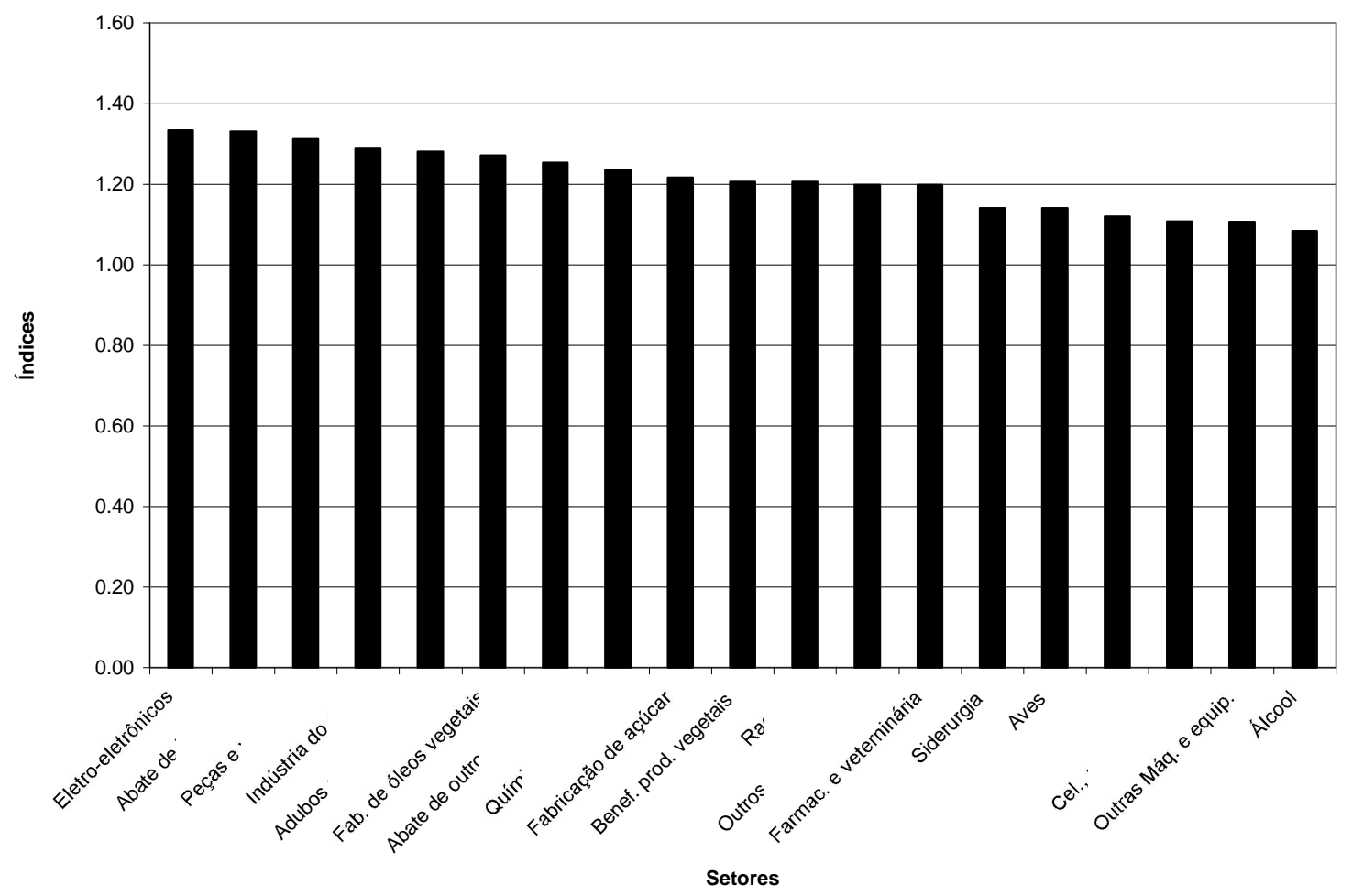

Figura 1 - Índices de Hirschman-Rasmussen para trás (Mato Grosso). 


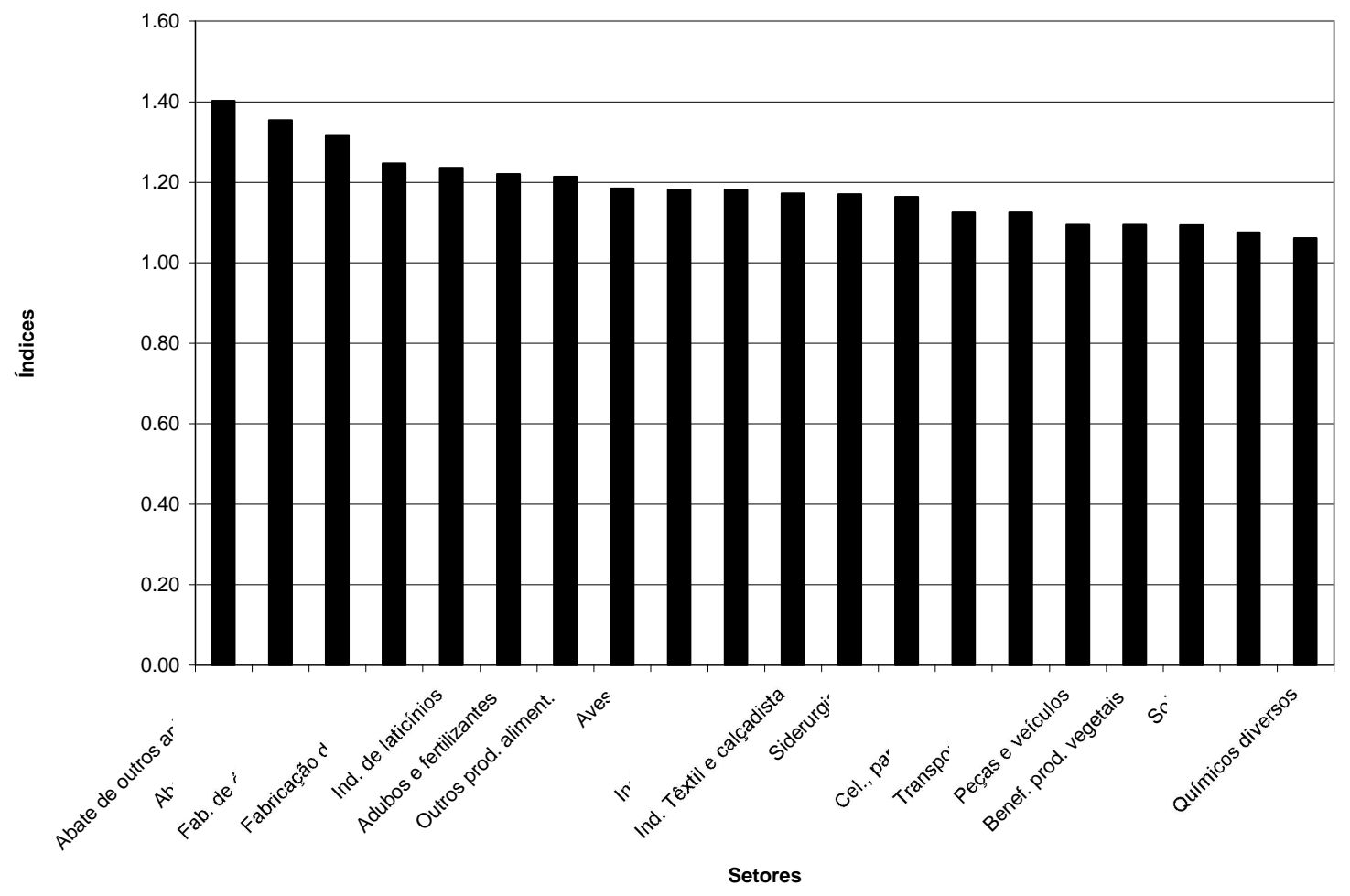

Figura 2 - Índices de Hirschman-Rasmussen para trás (resto do Brasil). 


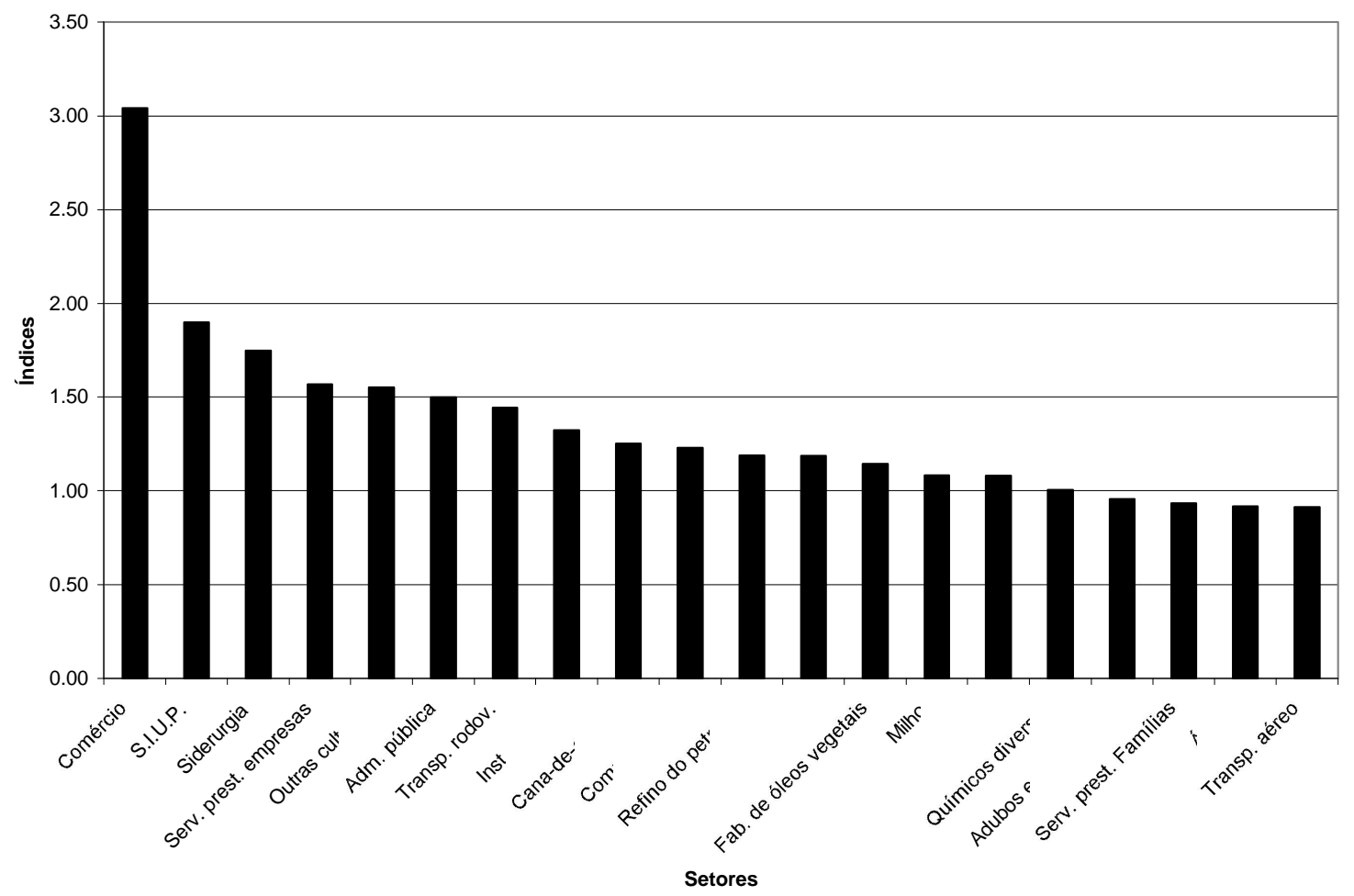

Figura 3 - Índices de Hirschman-Rasmussen para frente (Mato Grosso). 


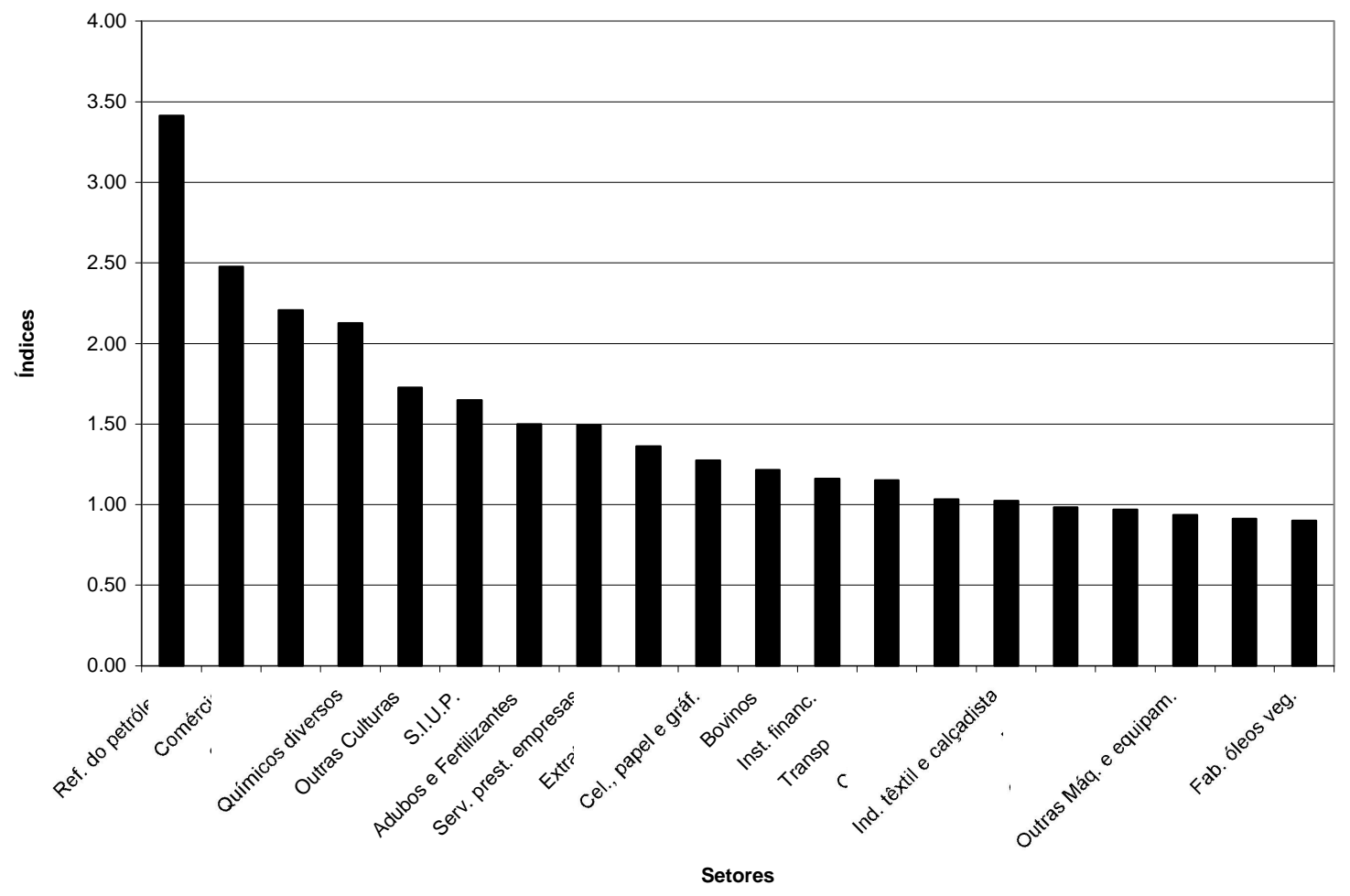

Figura 4 - Índices de Hirschman-Rasmussen para frente (resto do Brasil). 


\subsection{2 Índices puros de ligações normalizados}

As Tabelas 19 e 20 apresentam os valores dos índices puros normalizados para trás, frente e total, para o Mato Grosso e resto do Brasil, respectivamente. As figuras 5, $6,7,8,9$ e 10, permitem melhor visualização para os vinte setores com os maiores valores dos índices puros normalizados, em cada região.

Os índice puro de ligação para trás calculado para um determinado setor do Mato Grosso, mostra o impacto puro da produção deste setor sobre a produção dos demais setores do próprio Mato Grosso e do resto do Brasil. Chama-se puro pois são descontados a demanda de insumos pelo próprio setor e os efeitos feedback (ou retornos). Já o índice puro de ligação para frente calculado para este mesmo setor, mostra o impacto puro da produção total dos demais setores do Mato Grosso e resto do Brasil sobre sua produção. O mesmo raciocínio é utilizado para os valores dos índices para trás e para frente calculados para o resto do Brasil.

Valores dos índices puros de ligações totais normalizados acima de um, identificam os setores considerados como chave ou pólos de desenvolvimento econômico em uma região, porque suas produções impactam a produção do resto da economia, e são impactadas pela mesma, em uma proporção acima da média dentre os demais setores pertencentes à mesma região.

Conforme mostram os dados da Tabela 19, o Mato Grosso apresenta dezessete setores identificados como pólos de desenvolvimento, a saber: Soja (2), Bovinos (7), Outros pecuária (9), Fabricação de óleos vegetais (33), Abate de bovinos (30), Abate de outros animais (29), Álcool (22), Comércio (39), Administração pública (50), Serviços prestados æ̀̀ famílias (47), Serviços prestados à empresas (48), Construção civil (38), S.I.U.P. (37), Transporte rodoviário (40), Instituições financeiras (46), Comunicações (45) e Aluguel de imóveis (49). Note que sete destes setores estão diretamente relacionados à agropecuária, sendo que três destes pertencem æ̀ atividades primárias, o que também confirma a importância da agricultura dentro de uma economia, em termos de suas relações comerciais com as demais atividades. 
O setor Comércio (39), quando comparado com os outros, é o que mais impacta a produção do resto da economia, em 13,64 vezes acima da média, além de ser também o mais impactado por esta, em 6,76 vezes acima da média, ocupando a primeira posição no ranking dos setores chave ao desenvolvimento do estado. Já o setor Administração pública (50), embora seja relativamente pouco demandado, exerce um elevado impacto na produção total do restante da economia, em 7,37 vezes acima da média, colocando-o na segunda posição em termos de pólos de desenvolvimento econômico.

Conforme discutido na revisão de literatura, a pecuária bovina, embora de uns anos para cá tenha perdido espaço para a agricultura no Mato Grosso, especialmente para a soja, ainda se constitui um importante setor para a economia do estado, o que pode ser confirmado pela oitava posição no ranking dos setores-chave, ocupada pelo setor Bovinos (7), que impacta a produção do resto da economia em 1,67 vezes acima da média, enquanto é impactado por esta em 2,77 vezes acima da média.

O setor Soja (2), por sua vez, está demandando a produção do resto da economia em 1,19 vezes acima da média, enquanto é demandado por esta, em 3,29 vezes acima da média, ocupando, portanto, a sétima posição no ranking, um bom indicativo da importância que tem o setor em termos de aquecimento da economia do estado, em decorrência da sua forte relação com os demais setores econômicos, conforme sugeriu a revisão de literatura. Finalmente, deve-se destacar também, que embora o setor Fabricação de óleos vegetais (33) seja relativamente pouco demandado, este exerce um importante impacto sobre a produção do resto da economia, em 4,41 vezes acima da média, colocando-o na terceira posição do ranking de setores-chave. 
Tabela 19. Índices puros de ligações normalizados para o Mato Grosso.

\begin{tabular}{|c|c|c|c|c|c|c|c|}
\hline & & Trás & Ordem & Frente & Ordem & Total & Ordem \\
\hline 1 & Cana-de-açúcar & $-0,08$ & 45 & 1,32 & 13 & 0,62 & 21 \\
\hline 2 & Soja & 1,19 & 10 & 3,29 & 4 & 2,24 & 7 \\
\hline 3 & Milho & 0,00 & 42 & 0,60 & 21 & 0,30 & 27 \\
\hline 4 & Fruticultura & 0,05 & 34 & 0,37 & 28 & 0,21 & 31 \\
\hline 5 & Outras culturas & 0,23 & 22 & 1,08 & 15 & 0,65 & 20 \\
\hline 6 & Aves & 0,15 & 26 & 0,77 & 17 & 0,46 & 24 \\
\hline 7 & Bovinos & 1,67 & 9 & 2,77 & 6 & 2,22 & 8 \\
\hline 8 & Suínos & $-0,37$ & 50 & 1,06 & 16 & 0,34 & 26 \\
\hline 9 & Outros pecuária & 1,98 & 8 & 0,43 & 25 & 1,20 & 15 \\
\hline 10 & Extrativismo vegetal & $-0,11$ & 48 & 0,25 & 32 & 0,07 & 40 \\
\hline 11 & Silvicultura & 0,00 & 40 & 0,00 & 47 & 0,00 & 51 \\
\hline 12 & Extrativismo animal (Pesca) & 0,06 & 33 & 0,01 & 42 & 0,04 & 45 \\
\hline 13 & Extrativismo mineral & 0,00 & 41 & 0,46 & 24 & 0,23 & 30 \\
\hline 14 & Siderurgia & 0,25 & 19 & 1,27 & 14 & 0,76 & 19 \\
\hline 15 & Máquinas e Implementos agrícolas & 0,01 & 36 & 0,02 & 41 & 0,02 & 47 \\
\hline 16 & Outras máquinas e equipamentos & 0,01 & 37 & 0,01 & 44 & 0,01 & 48 \\
\hline 17 & Eletro-eletrônicos & 0,00 & 39 & 0,00 & 49 & 0,00 & 50 \\
\hline 18 & Peças e veículos & 0,01 & 38 & 0,00 & 50 & 0,00 & 49 \\
\hline 19 & Madeira e mobiliário & 0,60 & 14 & 0,53 & 23 & 0,57 & 22 \\
\hline 20 & Celulose, papel e gráfica & 0,17 & 24 & 0,11 & 35 & 0,14 & 34 \\
\hline 21 & Químicos diversos & 0,17 & 25 & 0,08 & 37 & 0,12 & 35 \\
\hline 22 & Álcool & 0,25 & 20 & 1,87 & 10 & 1,06 & 16 \\
\hline 23 & Refino do Petróleo & 0,23 & 21 & 0,11 & 36 & 0,17 & 32 \\
\hline 24 & Adubos e fertilizantes & 0,10 & 29 & 0,01 & 45 & 0,05 & 42 \\
\hline 25 & Farmácia e veterinária & 0,10 & 30 & 0,00 & 46 & 0,05 & 43 \\
\hline 26 & Indústria têxtil e calçadista & 0,17 & 23 & 0,01 & 43 & 0,09 & 39 \\
\hline 27 & Indústria do café & 0,07 & 32 & 0,00 & 48 & 0,04 & 44 \\
\hline 28 & Beneficiamento de produtos vegetais & 0,73 & 12 & 0,18 & 33 & 0,46 & 25 \\
\hline 29 & Abate de outros animais & 3,19 & 7 & 0,26 & 31 & 1,72 & 12 \\
\hline 30 & Abate de bovinos & 3,36 & 6 & 0,18 & 34 & 1,77 & 10 \\
\hline 31 & Indústria de laticínios & 0,01 & 35 & 0,04 & 40 & 0,03 & 46 \\
\hline 32 & Fabricação de açúcar & 0,67 & 13 & 0,39 & 27 & 0,53 & 23 \\
\hline 33 & Fabricação de óleos vegetais & 5,41 & 3 & 0,76 & 18 & 3,08 & 3 \\
\hline 34 & Rações & 0,27 & 18 & 0,04 & 39 & 0,15 & 33 \\
\hline 35 & Outros produtos alimentares & 1,14 & 11 & 0,39 & 26 & 0,77 & 18 \\
\hline 36 & Indústrias Diversas & 0,12 & 27 & 0,08 & 38 & 0,10 & 36 \\
\hline 37 & S.I.U.P & $-0,10$ & 46 & 3,81 & 3 & 1,85 & 9 \\
\hline 38 & Construção civil & 4,03 & 4 & 0,73 & 19 & 2,38 & 6 \\
\hline 39 & Comércio & 13,64 & 1 & 6,76 & 1 & 10,20 & 1 \\
\hline 40 & Transporte rodoviário & 0,60 & 15 & 2,85 & 5 & 1,73 & 11 \\
\hline 41 & Transporte aéreo & $-0,07$ & 44 & 0,57 & 22 & 0,25 & 29 \\
\hline 42 & Transporte ferroviário & $-0,14$ & 49 & 0,33 & 29 & 0,09 & 37 \\
\hline 43 & Transporte aquaviário & $-0,11$ & 47 & 0,30 & 30 & 0,09 & 38 \\
\hline 44 & Atividades auxiliares dos transportes & $-0,06$ & 43 & 0,63 & 20 & 0,29 & 28 \\
\hline 45 & Comunicações & 0,09 & 31 & 2,68 & 7 & 1,39 & 14 \\
\hline 46 & Instituições financeiras & 0,40 & 16 & 2,48 & 8 & 1,44 & 13 \\
\hline 47 & Serviços prestados às famílias & 3,77 & 5 & 2,13 & 9 & 2,95 & 4 \\
\hline 48 & Serviços prestados às empresas & $-0,62$ & 51 & 5,55 & 2 & 2,46 & 5 \\
\hline 49 & Aluguel de imóveis & 0,27 & 17 & 1,80 & 11 & 1,04 & 17 \\
\hline 50 & Administração pública & 7,37 & 2 & 1,64 & 12 & 4,51 & 2 \\
\hline 51 & Serviços privados não mercantis & 0,12 & 28 & 0,00 & 51 & 0,06 & 41 \\
\hline
\end{tabular}




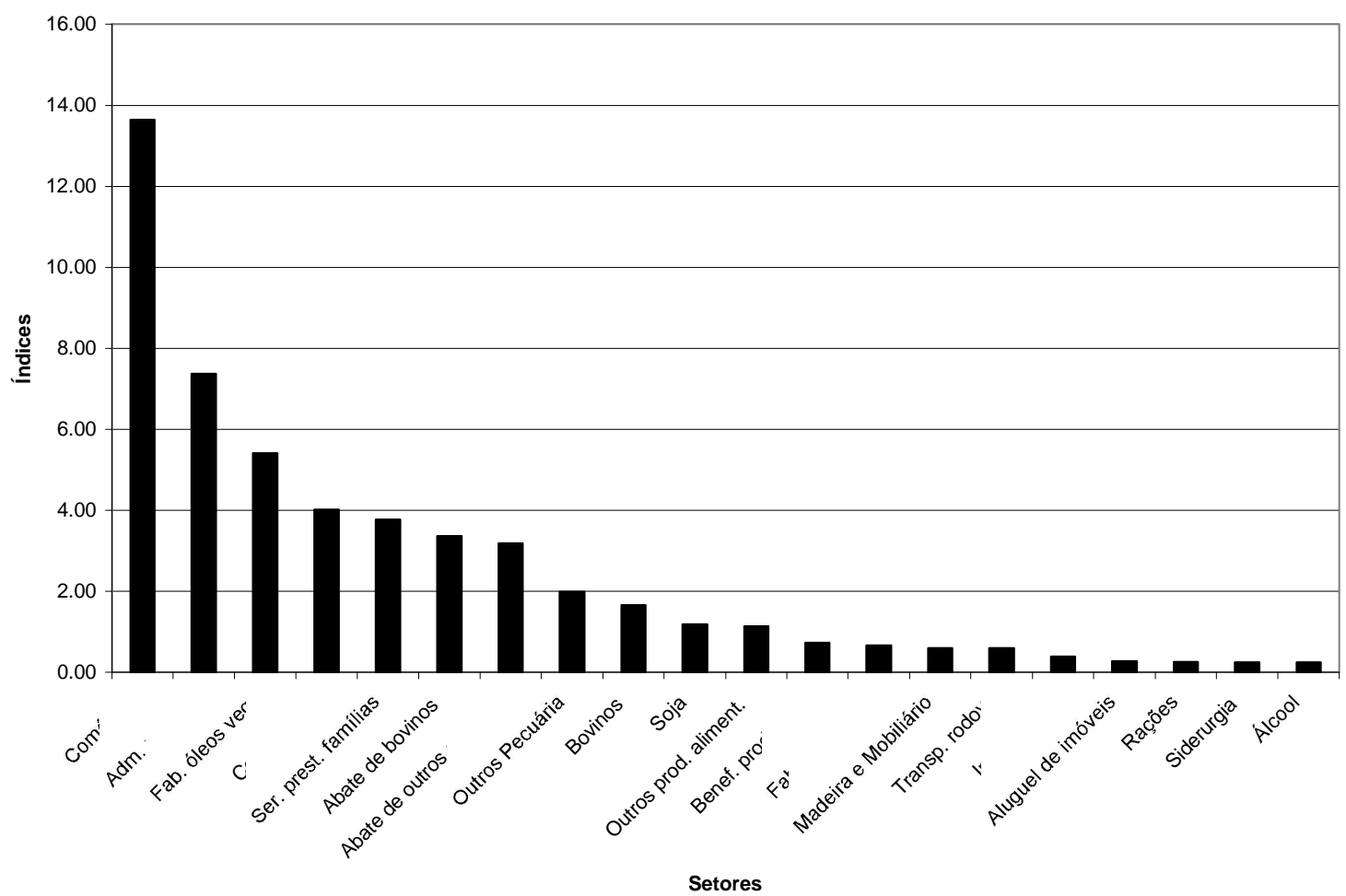

Figura 5 - Índices puros de ligações normalizados para trás (Mato Grosso). 


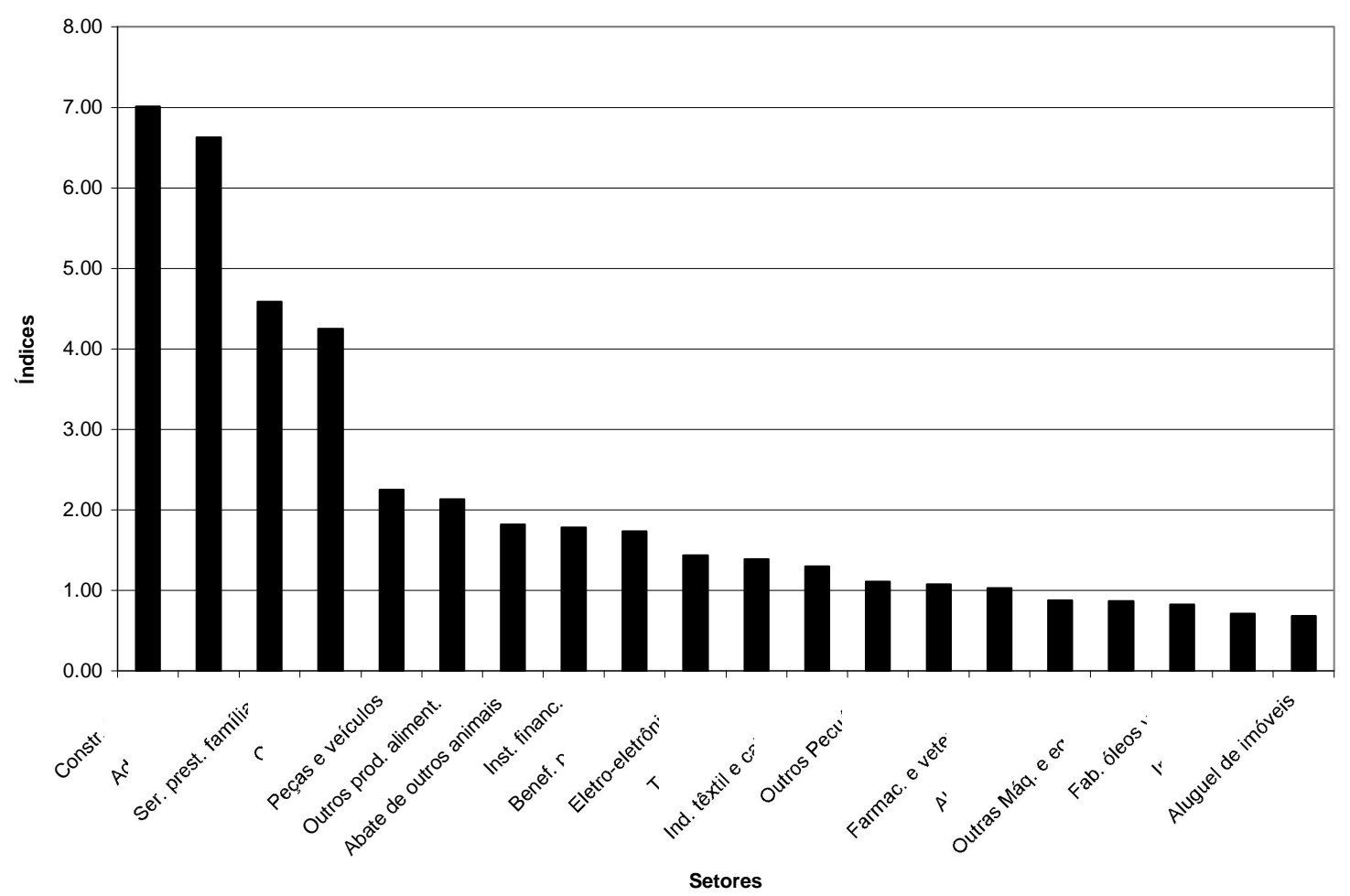

Figura 6 - Índices puros de ligações normalizados para trás (resto do Brasil). 


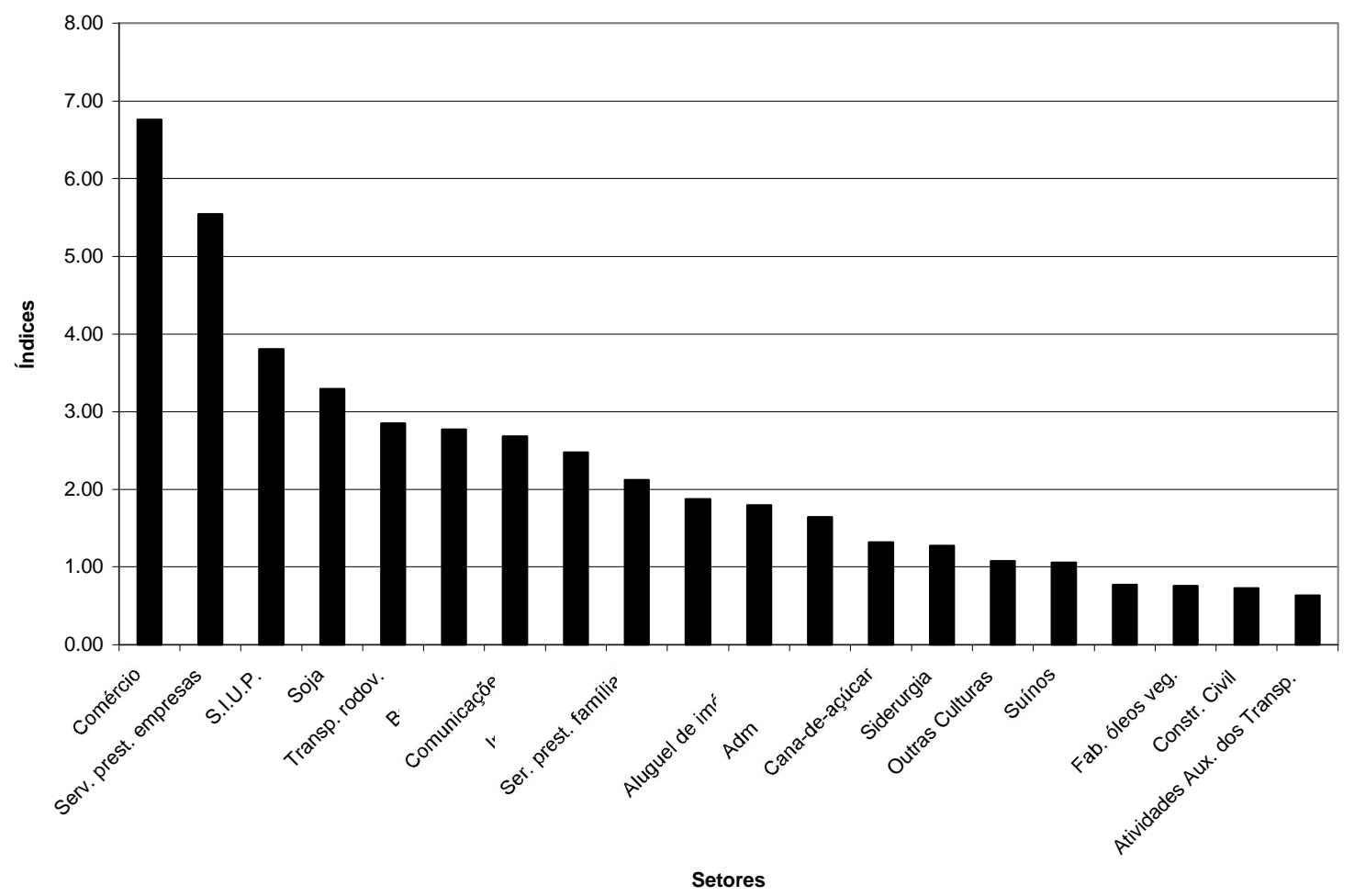

Figura 7 - Índices puros de ligações normalizados para frente (Mato Grosso). 
No caso do resto do Brasil, dezesseis setores destacam-se como pólos de desenvolvimento econômico, a saber, Comércio (39), Construção civil (32), Administração pública (50), Siderurgia (14), Serviços prestados æ̀̀ famílias (47), Refino do Petróleo (23), Serviços prestados à empresas (48), Químicos diversos (21), Instituições financeiras (46), Peças e veículos (18), S.I.U.P. (37), Outros produtos alimentares (35), Transporte rodoviário (40), Outras Culturas (5), Beneficiamento de produtos vegetais (28) e Celulose, papel e gráfica (20), como mostram os dados da Tabela 20. Note que no resto do Brasil os setores primários não têm o mesmo impacto quando comparados aos mesmos setores do Mato Grosso. 
Tabela 20. Índices puros de ligações normalizados para o Resto do Brasil.

\begin{tabular}{|c|c|c|c|c|c|c|c|}
\hline & & Trás & Ordem & Frente & Ordem & Total & Ordem \\
\hline 1 & Cana-de-açúcar & 0,01 & 46 & 0,44 & 28 & 0,23 & 41 \\
\hline 2 & Soja & 0,17 & 37 & 0,39 & 33 & 0,28 & 40 \\
\hline 3 & Milho & 0,05 & 43 & 0,39 & 32 & 0,22 & 43 \\
\hline 4 & Fruticultura & 0,07 & 42 & 0,37 & 35 & 0,22 & 42 \\
\hline 5 & Outras culturas & 0,43 & 27 & 2,21 & 7 & 1,32 & 14 \\
\hline 6 & Aves & 0,23 & 36 & 0,40 & 31 & 0,32 & 38 \\
\hline 7 & Bovinos & 0,64 & 22 & 0,86 & 16 & 0,75 & 24 \\
\hline 8 & Suínos & $-0,10$ & 51 & 0,45 & 27 & 0,17 & 44 \\
\hline 9 & Outros pecuária & 1,11 & 13 & 0,22 & 41 & 0,67 & 26 \\
\hline 10 & Extrativismo vegetal & 0,00 & 48 & 0,17 & 42 & 0,08 & 47 \\
\hline 11 & Silvicultura & 0,00 & 47 & 0,16 & 44 & 0,08 & 48 \\
\hline 12 & Extrativismo animal (Pesca) & 0,05 & 44 & 0,01 & 50 & 0,03 & 51 \\
\hline 13 & Extrativismo mineral & 0,11 & 40 & 1,71 & 9 & 0,91 & 22 \\
\hline 14 & Siderurgia & 1,08 & 14 & 5,57 & 1 & 3,32 & 4 \\
\hline 15 & Máquinas e Implementos agrícolas & 0,09 & 41 & 0,04 & 49 & 0,06 & 49 \\
\hline 16 & Outras máquinas e equipamentos & 0,87 & 17 & 0,96 & 14 & 0,91 & 21 \\
\hline 17 & Eletro-eletrônicos & 1,44 & 10 & 0,51 & 26 & 0,98 & 18 \\
\hline 18 & Peças e veículos & 2,25 & 5 & 0,68 & 18 & 1,47 & 10 \\
\hline 19 & Madeira e mobiliário & 0,62 & 23 & 0,42 & 30 & 0,52 & 28 \\
\hline 20 & Celulose, papel e gráfica & 0,46 & 25 & 1,75 & 8 & 1,10 & 16 \\
\hline 21 & Químicos diversos & 0,42 & 28 & 3,21 & 5 & 1,81 & 8 \\
\hline 22 & Álcool & 0,13 & 38 & 0,59 & 22 & 0,36 & 34 \\
\hline 23 & Refino do Petróleo & 0,31 & 33 & 5,57 & 2 & 2,93 & 6 \\
\hline 24 & Adubos e fertilizantes & $-0,01$ & 49 & 0,62 & 20 & 0,31 & 39 \\
\hline 25 & Farmácia e veterinária & 1,03 & 15 & 0,23 & 39 & 0,63 & 27 \\
\hline 26 & Indústria têxtil e calçadista & 1,30 & 12 & 0,59 & 21 & 0,95 & 19 \\
\hline 27 & Indústria do café & 0,72 & 19 & 0,05 & 48 & 0,39 & 31 \\
\hline 28 & Beneficiamento de produtos vegetais & 1,74 & 9 & 0,52 & 25 & 1,13 & 15 \\
\hline 29 & Abate de outros animais & 1,82 & 7 & 0,16 & 43 & 0,99 & 17 \\
\hline 30 & Abate de bovinos & 0,88 & 16 & 0,09 & 47 & 0,49 & 29 \\
\hline 31 & Indústria de laticínios & 0,64 & 21 & 0,11 & 46 & 0,38 & 33 \\
\hline 32 & Fabricação de açúcar & 0,43 & 26 & 0,22 & 40 & 0,33 & 37 \\
\hline 33 & Fabricação de óleos vegetais & 0,82 & 18 & 0,54 & 24 & 0,68 & 25 \\
\hline 34 & Rações & 0,31 & 32 & 0,38 & 34 & 0,35 & 36 \\
\hline 35 & Outros produtos alimentares & 2,13 & 6 & 0,55 & 23 & 1,34 & 12 \\
\hline 36 & Indústrias Diversas & 0,39 & 30 & 0,37 & 36 & 0,38 & 32 \\
\hline 37 & S.I.U.P & 0,38 & 31 & 2,54 & 6 & 1,46 & 11 \\
\hline 38 & Construção civil & 7,01 & 1 & 0,71 & 17 & 3,87 & 2 \\
\hline 39 & Comércio & 4,25 & 4 & 4,38 & 3 & 4,32 & 1 \\
\hline 40 & Transporte rodoviário & 1,39 & 11 & 1,26 & 13 & 1,33 & 13 \\
\hline 41 & Transporte aéreo & 0,59 & 24 & 0,32 & 38 & 0,46 & 30 \\
\hline 42 & Transporte ferroviário & $-0,03$ & 50 & 0,33 & 37 & 0,15 & 45 \\
\hline 43 & Transporte aquaviário & 0,04 & 45 & 0,13 & 45 & 0,08 & 46 \\
\hline 44 & Atividades auxiliares dos transportes & 0,27 & 34 & 0,44 & 29 & 0,35 & 35 \\
\hline 45 & Comunicações & 0,41 & 29 & 1,44 & 10 & 0,92 & 20 \\
\hline 46 & Instituições financeiras & 1,78 & 8 & 1,41 & 12 & 1,60 & 9 \\
\hline 47 & Serviços prestados às famílias & 4,58 & 3 & 1,42 & 11 & 3,01 & 5 \\
\hline 48 & Serviços prestados às empres as & 0,26 & 35 & 3,57 & 4 & 1,91 & 7 \\
\hline 49 & Aluguel de imóveis & 0,68 & 20 & 0,86 & 15 & 0,77 & 23 \\
\hline 50 & Administração pública & 6,63 & 2 & 0,65 & 19 & 3,65 & 3 \\
\hline 51 & Serviços privados não mercantis & 0,12 & 39 & 0,00 & 51 & 0,06 & 50 \\
\hline
\end{tabular}




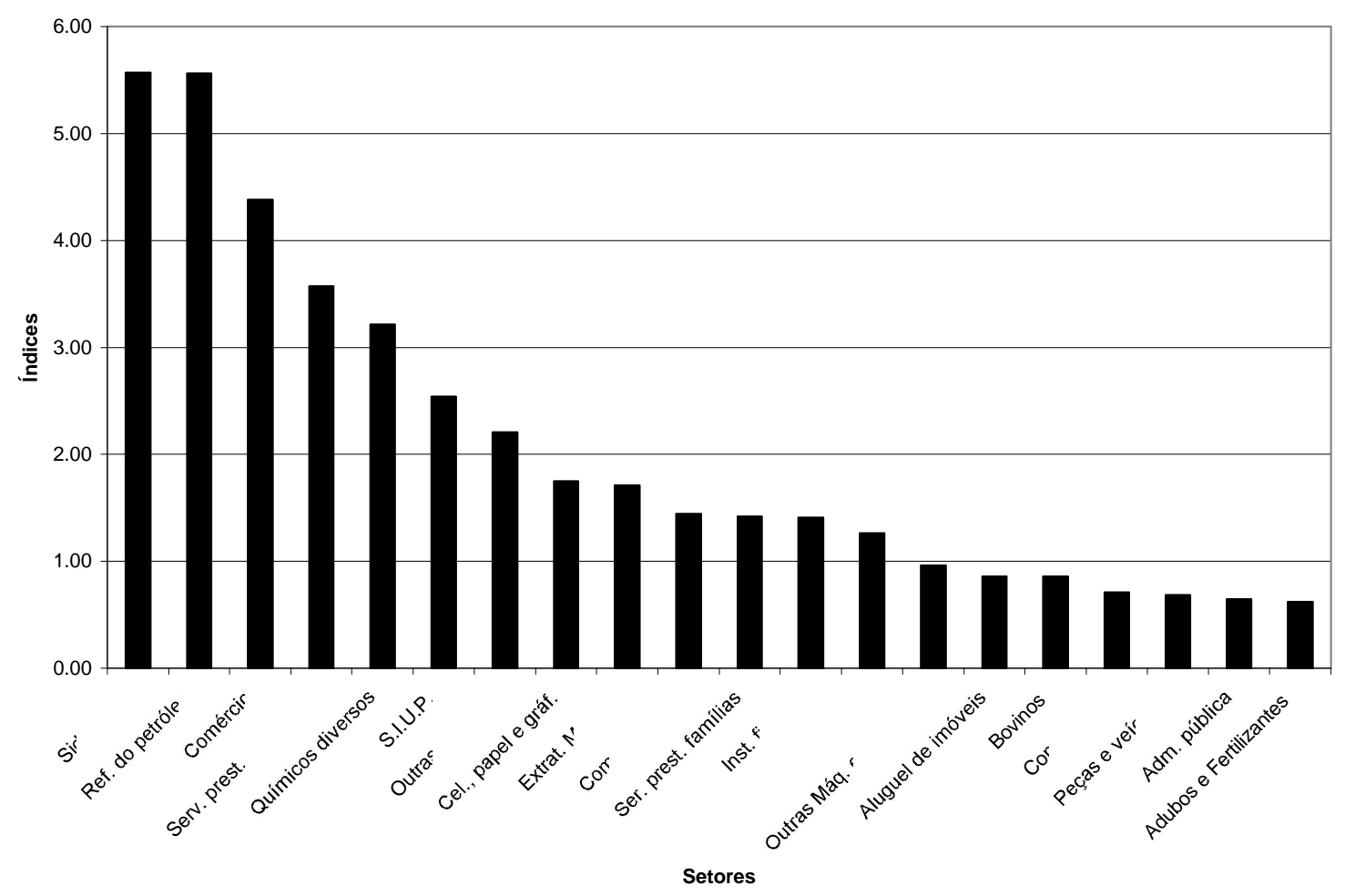

Figura 8 - Índices puros de ligações normalizados para frente (resto do Brasil). 


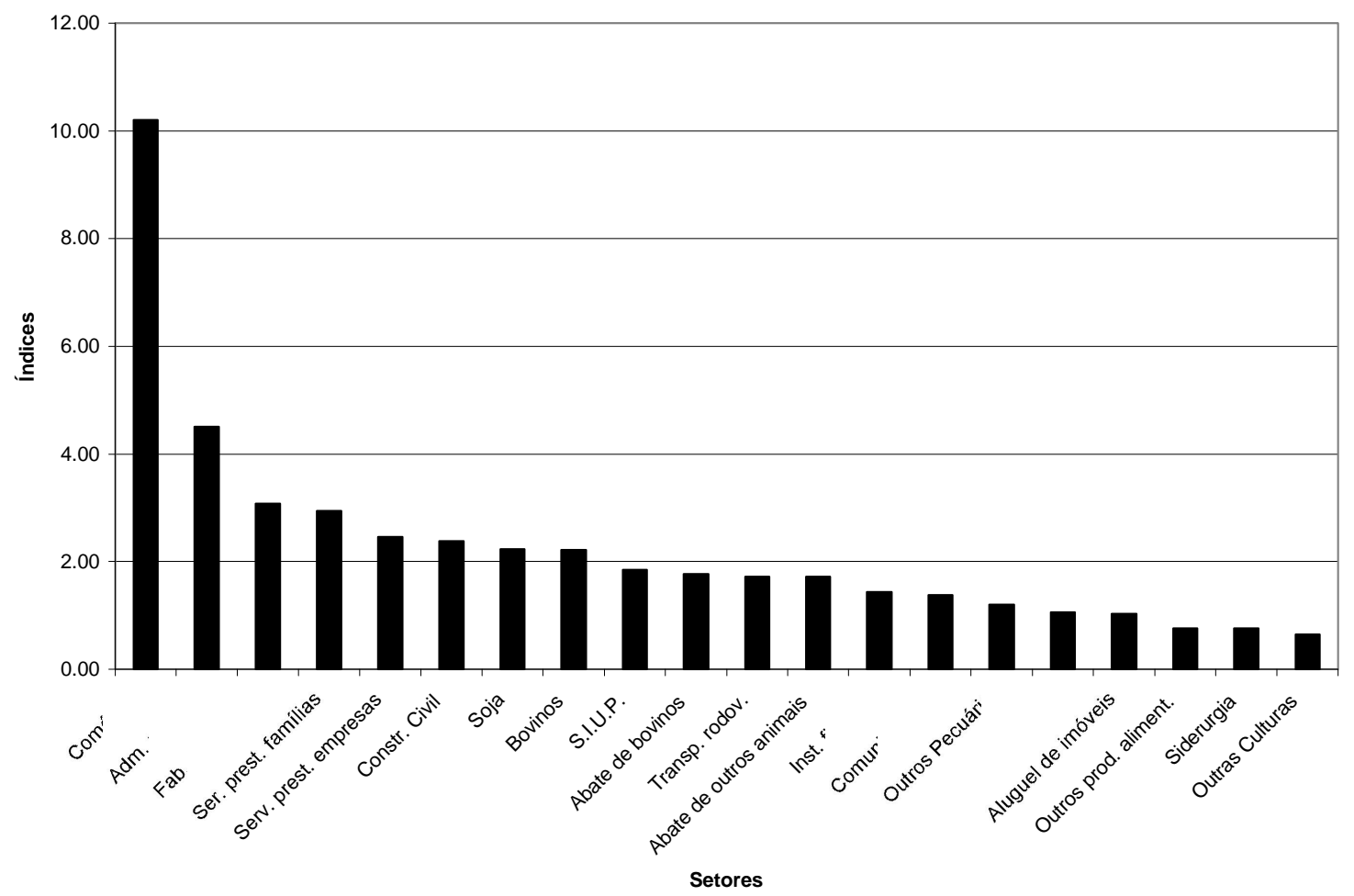

Figura 9 - Índices puros de ligações normalizados totais (Mato Grosso). 


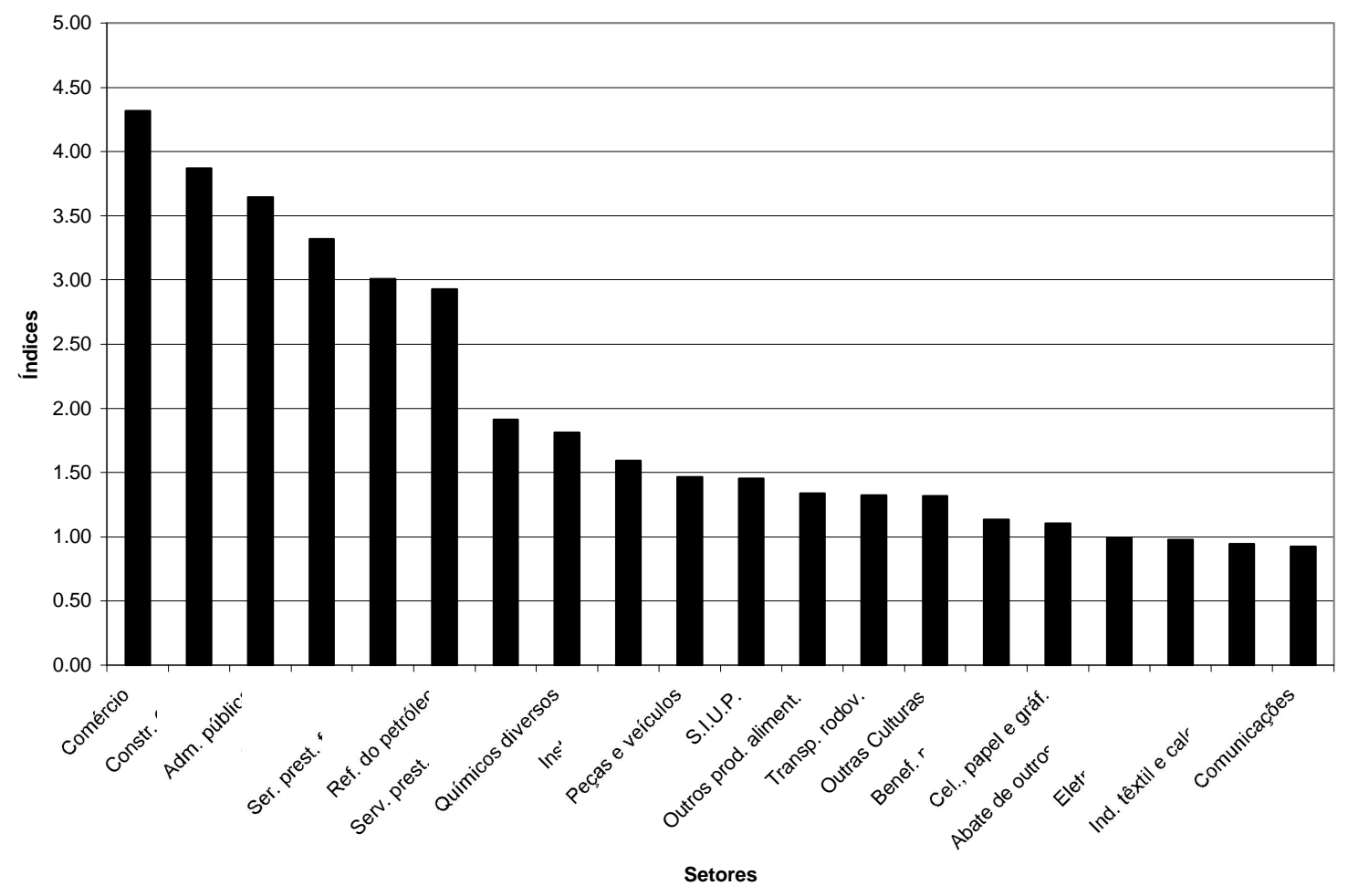

Figura 10 - Índices puros de ligações normalizados totais (resto do Brasil). 


\subsection{Coeficientes do campo de influência}

Objetivando complementar a análise feita pelos índices de ligações de Rasmussen-Hirschman, foram calculados os coeficientes do campo de influência, os quais permitem a visualização dos principais elos de ligação dentro da economia, ou seja, quais seriam os coeficientes que, se alterados, teriam um maior impacto no sistema como um todo.

O conceito do campo de influência descreve como se distribuem as mudanças dos coeficientes diretos no sistema econômico como um todo, permitindo, dessa forma, que se determinem quais as relações entre os setores que seriam mais importantes dentro do processo produtivo, em termos de suas relações de compra e venda com os demais. Assim como os índices de Rasmussen-Hirschman, os coeficientes do campo de influência não levam em consideração o valor da produção em cada atividade. 
Para a região do Mato Grosso, a Figura 11 mostra que os principais coeficientes do campo de influência constituem-se das vendas dos setores Siderurgia (14) e Adubos e fertilizantes (24) para os setores Siderurgia (14), Adubos e fertilizantes (24), S.I.U.P. (37), Abate de bovinos (30) e Fabricação de óleos vegetais (33); bem como vendas da Fabricação de óleos vegetais (33) para S.I.U.P. (37) e de S.I.U.P. (37) para Siderurgia (14), Químicos diversos (21), Adubos e fertilizantes (24), Indústria do café (27), Abate de bovinos (30), Fabricação de óleos vegetais (33) e S.I.U.P. (37).

Em geral, os setores identificados como chave pelo critério restrito de McGilvray (1977) são também identificados como os de maiores coeficientes do campo de influência, o que se justifica pelo fato de que se o setor tiver fortes ligações tanto de compra quanto de venda, possivelmente exercerá uma forte influência nas relações de compra e venda da matriz como um todo. Esta observação cabe também aos coeficientes do campo de influência para os setores pertencentes ao resto do Brasil.

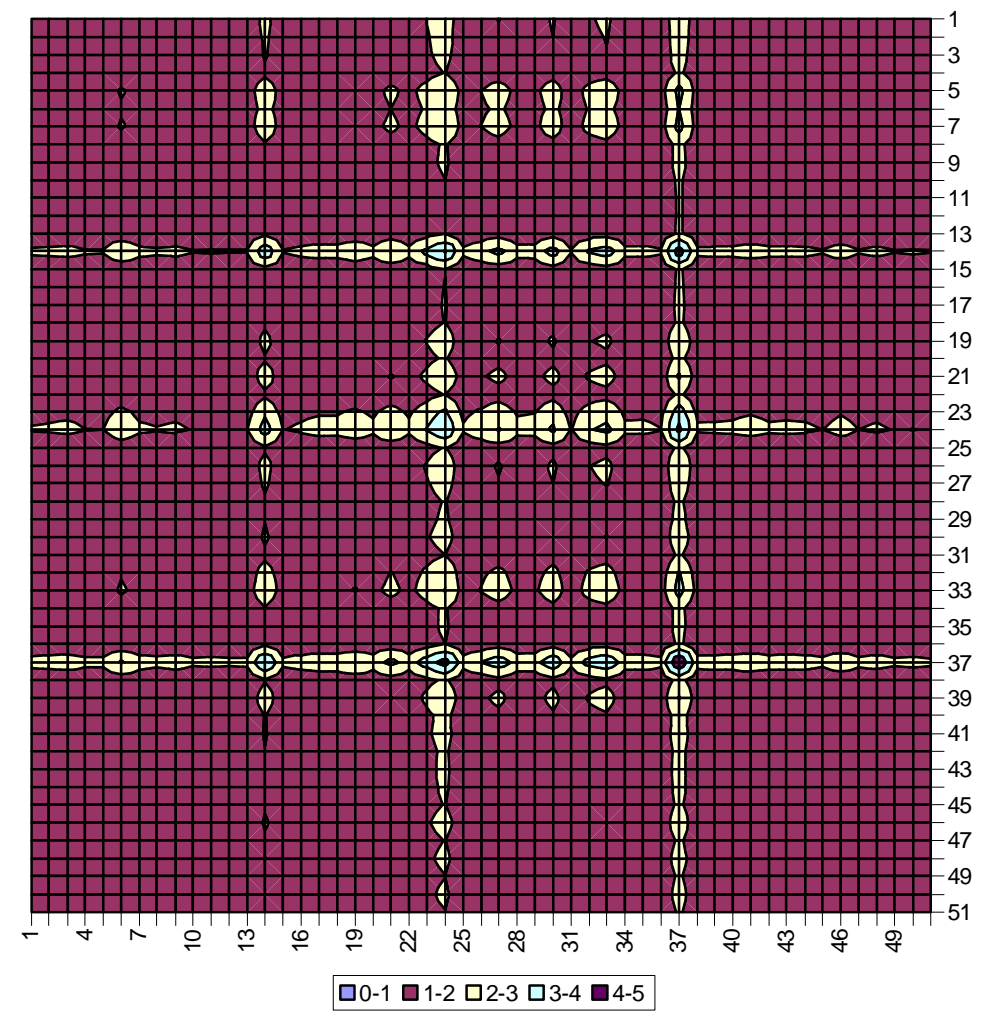

Figura 11 - Campo de influência para o estado do Mato Grosso. 
No caso do resto do Brasil, a Figura 12 mostra que os principais coeficientes dos campos de influência encontram-se nas vendas dos setores Siderurgia (14) e Refino do Petróleo (23) para os setores S.I.U.P. (37), Indústria têxtil e calçadista (26), Adubos e fertilizantes (24), Celulose, papel e gráfica (20), Siderurgia (14), Fabricação de óleos vegetais (33), Outros produtos alimentares (35) e Indústrias diversas (36); nas vendas da Indústria têxtil e calçadista (26) para o próprio setor, para Adubos e fertilizantes (24) e para a Siderurgia (14); e nas vendas do S.I.U.P. (37) para a Indústria têxtil e calçadista (26).

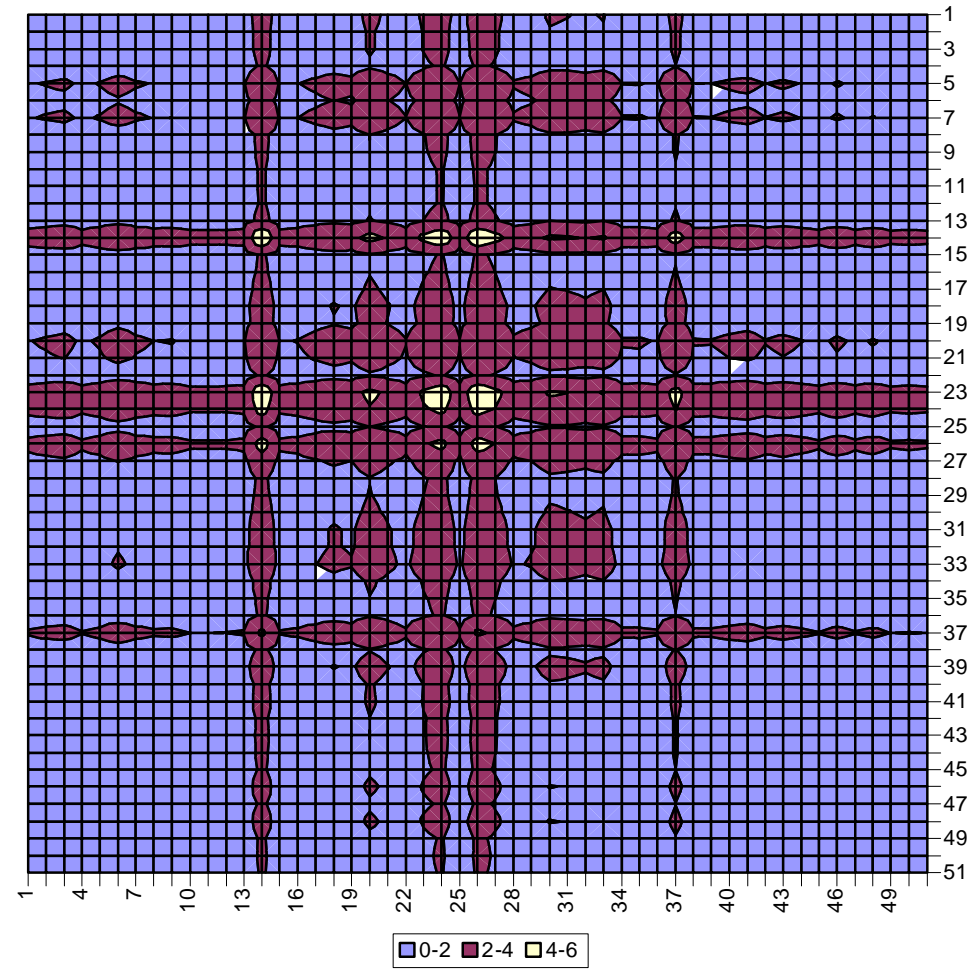

Figura 12 - Campo de influência para o resto do Brasil. 


\subsection{Multiplicadores}

Conforme discutido no referencial teórico, o modelo insumo-produto permite mensurar o efeito de uma mudança exógena na demanda final de um determinado setor sobre o número de pessoas ocupadas, o nível de renda gerada (em termos salariais) e a produção total gerada na economia, através dos multiplicadores tipos I e II, de emprego, renda e produção, respectivamente. O multiplicador de emprego tipo I mostra os impactos diretos e indiretos, ou seja, permite auferir quantos empregos são gerados na economia, direta e indiretamente, devido a uma variação na demanda final de uma determinada indústria, o suficiente para criar um emprego adicional na mesma. De forma análoga, os multiplicadores tipo I de renda e produção permitem a determinação da quantidade de renda e da produção total, geradas na economia em decorrência de uma unidade monetária adicional de renda (salário líquido) e produção em cada setor, respectivamente. A idéia do multiplicador tipo II é conceitualmente a mesma, diferindose, entretanto, pela endogeneização do consumo das famílias, produzindo assim os efeitos diretos, indiretos e induzidos.

Este último efeito refere-se à quantidade de empregos, nível de renda e produção, gerados em decorrência do consumo das famílias endogeneizado no sistema, e

pode ser calculado pela diferença entre os dois multiplicadores. Em outras palavras, o aumento na demanda final leva ao crescimento da produção na mesma proporção, implicando aumentos de emprego e consequente expansão de renda, o que leva, por sua vez, ao aumento de demanda por bens de consumo por parte das famílias, implicando em aumento da produção desses bens, o que resulta também em aumento de empregos e salários nestes setores.

No entanto, para melhor avaliar a capacidade de geração de empregos e renda de cada indústria, deve-se determinar, além dos multiplicadores, os geradores de emprego e renda. Ao atender a demanda final de um determinado setor da economia em um milhão de Reais, os geradores de empregos diretos, indiretos e induzidos trazem o número de pessoas ocupadas diretamente no setor, indiretamente nos demais setores e aqueles empregos gerados pelo efeito induzido pelo consumo das famílias 
endogeneizado, respectivamente. De forma análoga, os geradores de renda diretos, indiretos e induzidos trazem a quantidade total de renda gerada na economia de forma direta, indireta e induzida. A soma dos três indicadores representa a geração total de emprego e renda, respectivamente, ao atender a demanda final de cada setor em um milhão de Reais.

É importante que os multiplicadores e geradores sejam analisados conjuntamente, uma vez que existe uma relação inversa entre seus valores, ou seja, de modo geral, aqueles setores que apresentam um elevado efeito multiplicador de emprego e / ou renda, costumam apresentar baixa geração de emprego e / ou renda ao atenderem a sua demanda final em um milhão de Reais. Setores intensivos em capital, cujas produtividades do trabalho são elevadas, geram poucos empregos e conseqüentemente poucos salários ao atenderem suas demandas finais; entretanto, têm um elevado efeito multiplicador sobre o número de empregos e a geração de renda na economia, ao empregarem pessoas nas atividades fornecedoras de insumos para as suas produções.

\subsubsection{Geração de emprego}

Segundo os valores apresentados na Tabela 21, de uma maneira geral, ao atender a demanda final dos setores do Mato Grosso em um milhão de Reais, são gerados mais empregos do que ao atender a mesma demanda final dos setores pertencentes ao resto do Brasil, o que pode ser um indicativo de que a tecnologia de produção do Mato Grosso exige maior quantidade de mão-de-obra em relação àdo resto do Brasil. Entretanto, para alguns setores como Cana-de-açúcar (1), Soja (2), Milho (3), Fruticultura (4), Álcool (22), Fabricação de açúcar (32), Fabricação de óleos vegetais (33), Comércio (39) e Transporte rodoviário (40), ocorre justamente o contrário, ou seja, ao atender a demanda final do Mato Grosso são gerados menos empregos do que ao atender a demanda final destes mesmos setores situados no resto do Brasil, sugerindo que para estas atividades, a tecnologia de produção no Mato Grosso necessita de menor quantidade de mão-de-obra, ou seja, tem uma maior produtividade do trabalho. É importante observar que todos estes setores identificados como de possível maiores 
produtividades do trabalho no Mato Grosso, estão diretamente relacionados à atividades agrícolas, que de acordo com a revisão de literatura, são muito importantes dentro da economia do estado.

A atividade que mais gera empregos na economia ao atender a sua demanda final, tanto no Mato Grosso (718 empregos) quanto no resto do Brasil (599 empregos), é o setor Serviços privados não mercantis (51), que corresponde aos serviços contratados por "donas de casa", como, por exemplo, empregada doméstica, encanador, dentre outros, ou seja, um setor intensivo em mão-de-obra, caracterizado pela baixa produtividade do trabalho, empregando muitas pessoas a baixos salários. 
Tabela 21. Geração de emprego total para a variação de um milhão de reais da demanda final.

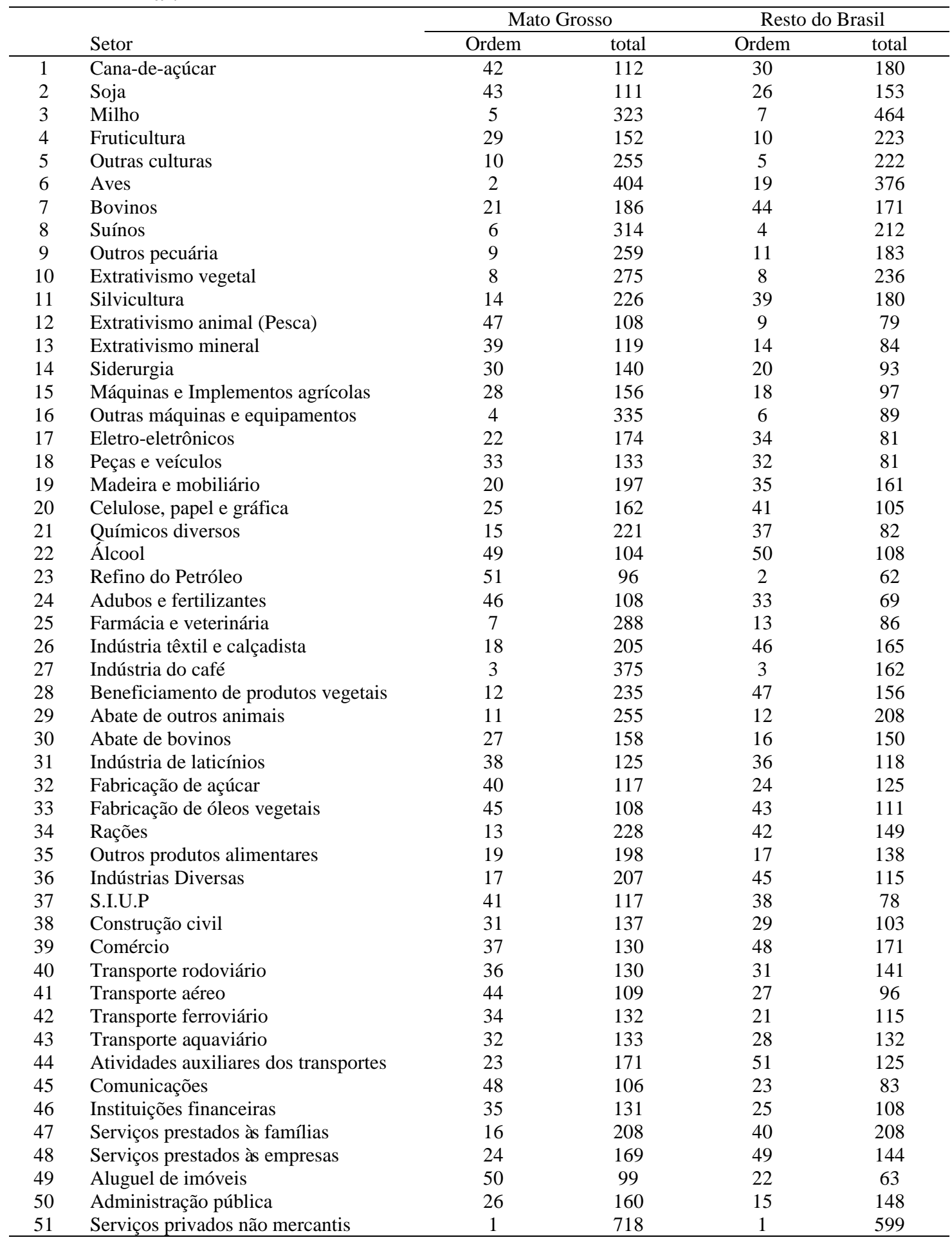


A Tabela 22 apresenta os valores da geração de empregos totais desagregados em empregos diretos, indiretos e induzidos. $\mathrm{O}$ aumento do valor total dos salários pagos em empregos diretos e indiretos gerados irá desencadear um efeito induzido pelo maior consumo das famílias na geração de novos empregos.

Os dados mostram que o número de empregos diretos gerados no setor Soja (2) do Mato Grosso ao atender a sua demanda final é baixo, inclusive menor do que o encontrado neste mesmo setor situado no resto do Brasil, o que sugere maior mecanização do setor no Mato Grosso em relação ao setor no resto do Brasil. Já em termos de geração de empregos indiretos, seu valor é aproximadamente quatro vezes maior do que a geração de empregos diretos, em decorrência da demanda intensiva da soja por insumos como fertilizantes, máquinas e implementos agrícolas, dentre outros, confirmando a importância do setor em termos de geração de empregos nas atividades fornecedoras de insumos àsua produção.

O setor Cana-de-açúcar (1) no Mato Grosso também emprega pouca gente de maneira direta quando comparado com o resto do Brasil, entretanto deve-se lembrar que o estado produz pouca cana-de-açúcar, conforme sugerido por sua baixa geração de empregos indiretos.

Note que o setor Milho (3) chama atenção pela grande quantidade de empregos diretos gerados no setor ao atender a demanda final tanto do Mato Grosso quanto do resto do Brasil, pois, em termos médios, o milho é uma cultura relativamente menos mecanizada do que a soja, caracterizando-se como um setor relativamente mais intensivo em mão-de-obra e, portanto, realmente emprega maior quantidade de pessoas. Entretanto vale ressaltar que os dados da matriz contemplam a tecnologia média do estado, ou seja, incorporam tanto a pequena produção quanto as lavouras altamente mecanizadas. No caso da soja, a pequena propriedade exerce pouca influência na oferta agregada, o que garante um padrão de mecanização da lavoura relativamente elevado.

Os setores Outras culturas (5), Aves (6), Suínos (8), Outros pecuária (9), Extrativismo vegetal (10) e Silvicultura (11) apresentam elevada geração de empregos diretos, inclusive em maior quantidade quando comparados com a geração de empregos indiretos, sugerindo que estas atividades sejam intensivas em mão-de-obra tanto no 
Mato Grosso quanto no resto do Brasil, caracterizando a importância destes setores primários no que diz respeito à geração de empregos diretamente nas próprias atividades.

Observa-se que apesar dos setores Abate de outros animais (29), Abate de bovinos (30) e Fabricação de óleos vegetais (33) gerarem poucos empregos diretos ao atenderem suas demandas finais em um milhão de Reais, estes geram maior quantidade de empregos indiretos, pois se tratam de setores altamente produtivos tanto no Mato Grosso quanto no resto do Brasil, e assim como no caso da soja, são importantes na geração de empregos nas atividades fornecedoras de insumos àsua produção.

Os dados mostram, que de um modo geral, os setores terciários (serviços) costumam gerar baixa quantidade de empregos indiretos na economia. Com relação aos Serviços privados não mercantis (51), os dados sugerem que se trata de um setor com baixa produtividade do trabalho, caracterizado pela alta geração de empregos diretos e empregos induzidos pelo consumo das famílias, e baixa geração de empregos indiretos. 
Tabela 22. Geração de empregos diretos, indiretos e induzidos para a variação de um milhão de reais da demanda final.

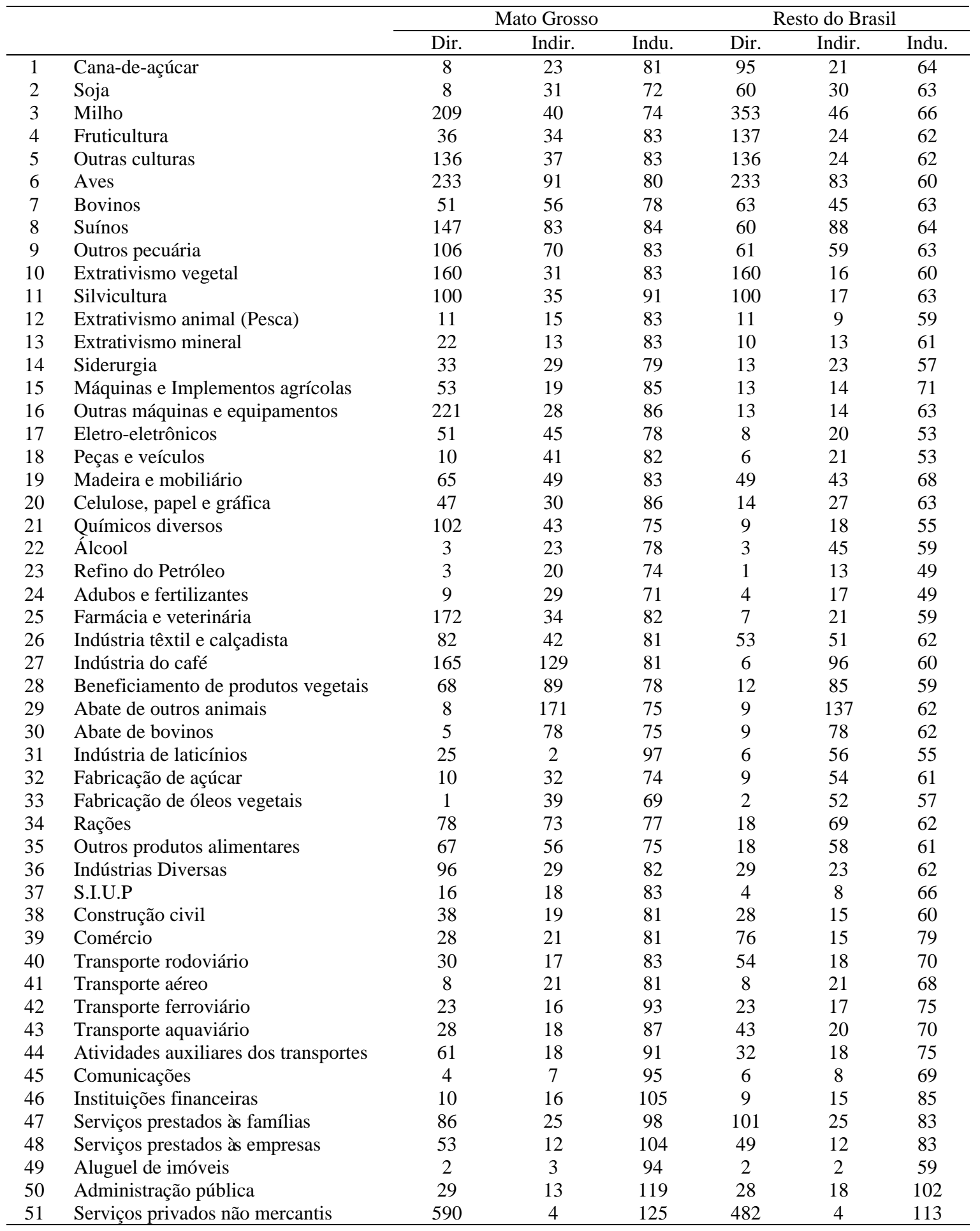


No que diz respeito ao efeito multiplicador de empregos na economia, de acordo com os valores apresentados na Tabela 23, para cada emprego gerado no setor Fabricação de óleos vegetais (33) do Mato Grosso, são gerados 63,83 empregos adicionais na economia, e ao considerar o efeito induzido pelo consumo das famílias, este valor sobe para 178,66 empregos, ou seja, 114,83 empregos adicionais são decorrentes deste efeito. Como esta indústria apresenta elevado padrão de automatização relativamente à indústrias presentes no Estado, ou seja, é relativamente intensiva em capital, gera um grande volume de produção por pessoa empregada, o que justifica a grande quantidade de empregos gerados no restante da economia para cada emprego adicional gerado na mesma, colocando-a na primeira posição em relação æ̀ demais atividades do Mato Grosso, em termos de efeito multiplicador de empregos, mais um dos indicativos da importância do setor para a economia da região.

Entretanto, outros setores da economia mato-grossense destacam-se também como importantes multiplicadores de emprego para cada pessoa adicional ocupada no próprio setor. As atividades Abate de outros animais (29) e Abate de bovinos (30) geram, respectivamente, 21,34 e 17,32 empregos indiretos, e quando se considera o efeito induzido, geram 30,72 e 33,78 empregos, estando entre os setores com maior efeito multiplicador de empregos do estado. Os setores Álcool (22) e Refino do Petróleo (23) são também considerados importantes multiplicadores de emprego na economia, sendo responsáveis pela geração de 6,84 e 7,50 empregos indiretos, e 30,55 e 35,88 empregos induzidos pelo consumo das famílias, respectivamente. Novamente, como se pode verificar, com exceção do Refino do petróleo (23), todos estes setores estão diretamente relacionados àagropecuária.

Outro setor do Mato Grosso que se destaca como um dos mais importantes multiplicadores de empregos na economia brasileira, é o setor Soja (2), responsável pela geração de 3,81 empregos para cada pessoa adicional ocupada na atividade e, 12,66 empregos quando endogeneizado o consumo das famílias.

Merece destaque ainda no Mato Grosso o setor Cana-de-açúcar (1), responsável pela geração de 3 empregos indiretos e 13,41 empregos induzidos pelo consumo endogeneizado das famílias, para cada emprego adicional gerado no próprio setor. 
Verifica-se que grande parte dos setores mato-grossenses que apresentam elevado efeito multiplicador do emprego pertencem aos setores primários, ou estão diretamente relacionados à eles, o que vem a confirmar mais uma vez a importância da agropecuária para a economia do estado. 
Tabela 23. Multiplicadores de emprego tipos I e II para o Mato Grosso.

\begin{tabular}{|c|c|c|c|c|c|}
\hline & & Ordem & $\mathrm{I}$ & Ordem & II \\
\hline 1 & Cana-de-açúcar & 10 & 4,00 & 9 & 14,41 \\
\hline 2 & Soja & 7 & 4,81 & 11 & 13,66 \\
\hline 3 & Milho & 48 & 1,19 & 49 & 1,55 \\
\hline 4 & Fruticultura & 20 & 1,93 & 25 & 4,21 \\
\hline 5 & Outras culturas & 44 & 1,27 & 45 & 1,88 \\
\hline 6 & Aves & 38 & 1,39 & 46 & 1,73 \\
\hline 7 & Bovinos & 18 & 2,10 & 27 & 3,63 \\
\hline 8 & Suínos & 32 & 1,56 & 44 & 2,14 \\
\hline 9 & Outros pecuária & 28 & 1,66 & 38 & 2,44 \\
\hline 10 & Extrativismo vegetal & 47 & 1,20 & 47 & 1,71 \\
\hline 11 & Silvicultura & 39 & 1,35 & 41 & 2,26 \\
\hline 12 & Extrativismo animal (Pesca) & 14 & 2,37 & 15 & 10,18 \\
\hline 13 & Extrativismo mineral & 31 & 1,60 & 19 & 5,38 \\
\hline 14 & Siderurgia & 21 & 1,88 & 23 & 4,29 \\
\hline 15 & Máquinas e Implementos agrícolas & 40 & 1,35 & 33 & 2,97 \\
\hline 16 & Outras máquinas e equipamentos & 49 & 1,13 & 50 & 1,52 \\
\hline 17 & Eletro-eletrônicos & 22 & 1,88 & 30 & 3,39 \\
\hline 18 & Peças e veículos & 6 & 5,32 & 10 & 13,94 \\
\hline 19 & Madeira e mobiliário & 25 & 1,76 & 32 & 3,03 \\
\hline 20 & Celulose, papel e gráfica & 30 & 1,63 & 28 & 3,46 \\
\hline 21 & Químicos diversos & 37 & 1,43 & 42 & 2,16 \\
\hline 22 & Álcool & 5 & 7,84 & 6 & 31,55 \\
\hline 23 & Refino do Petróleo & 4 & 8,50 & 3 & 36,88 \\
\hline 24 & Adubos e fertilizantes & 8 & 4,10 & 13 & 11,77 \\
\hline 25 & Farmácia e veterinária & 46 & 1,20 & 48 & 1,68 \\
\hline 26 & Indústria têxtil e calçadista & 34 & 1,51 & 37 & 2,49 \\
\hline 27 & Indústria do café & 24 & 1,78 & 40 & 2,27 \\
\hline 28 & Beneficiamento de produtos vegetais & 15 & 2,30 & 29 & 3,45 \\
\hline 29 & Abate de outros animais & 2 & 22,34 & 5 & 31,72 \\
\hline 30 & Abate de bovinos & 3 & 18,32 & 4 & 34,78 \\
\hline 31 & Indústria de laticínios & 50 & 1,10 & 20 & 4,94 \\
\hline 32 & Fabricação de açúcar & 9 & 4,05 & 14 & 11,17 \\
\hline 33 & Fabricação de óleos vegetais & 1 & 64,83 & 1 & 179,66 \\
\hline 34 & Rações & 19 & 1,93 & 35 & 2,92 \\
\hline 35 & Outros produtos alimentares & 23 & 1,84 & 34 & 2,97 \\
\hline 36 & Indústrias Diversas & 41 & 1,31 & 43 & 2,16 \\
\hline 37 & S.I.U.P & 17 & 2,15 & 16 & 7,49 \\
\hline 38 & Construção civil & 35 & 1,50 & 26 & 3,65 \\
\hline 39 & Comércio & 26 & 1,74 & 22 & 4,65 \\
\hline 40 & Transporte rodoviário & 33 & 1,55 & 24 & 4,27 \\
\hline 41 & Transporte aéreo & 11 & 3,74 & 8 & 14,53 \\
\hline 42 & Transporte ferroviário & 27 & 1,71 & 17 & 5,77 \\
\hline 43 & Transporte aquaviário & 29 & 1,63 & 21 & 4,68 \\
\hline 44 & Atividades auxiliares dos transportes & 42 & 1,30 & 36 & 2,78 \\
\hline 45 & Comunicações & 12 & 2,71 & 7 & 26,65 \\
\hline 46 & Instituições financeiras & 13 & 2,51 & 12 & 12,60 \\
\hline 47 & Serviços prestados às famílias & 43 & 1,29 & 39 & 2,44 \\
\hline 48 & Serviços prestados às empresas & 45 & 1,23 & 31 & 3,17 \\
\hline 49 & Aluguel de imóveis & 16 & 2,17 & 2 & 45,50 \\
\hline 50 & Administração pública & 36 & 1,44 & 18 & 5,53 \\
\hline 51 & Serviços privados não mercantis & 51 & 1,01 & 51 & 1,22 \\
\hline
\end{tabular}

A Tabela 24 mostra os valores dos multiplicadores de emprego tipos I e II calculados para os setores pertencentes ao resto do Brasil. 
É possível notar que, assim como no Mato Grosso, o setor Fabricação de óleos vegetais (33) no resto do Brasil, destaca-se como o principal multiplicador de empregos na economia, gerando 24,31 empregos indiretos, e 51,11 empregos induzidos pelo consumo endogeneizado das famílias, o que significa dizer que 26,8 empregos são gerados por este último efeito. Isto pode ser explicado pela grande importância que tem o sistema agroindustrial da soja no Brasil, conforme foi colocado pela revisão de literatura.

Os setores Álcool (22), Refino do petróleo (23), Abate de outros animais (29) e Abate de bovinos (30) no resto do Brasil também se destacaram como importantes multiplicadores de empregos na economia. Chama atenção a importância do consumo das famílias na geração de empregos da indústria de Refino do petróleo (23), responsável pela geração de 83,09 empregos adicionais na economia. Provavelmente a renda adicional à famílias decorrente dos empregos diretos e indiretos gerados pela produção do setor é elevada a ponto de gerar este significativo efeito induzido.

Alguns setores pertencentes ao agronegócio brasileiro, como Indústria do café (27), Indústria de laticínios (31) e Fabricação de Açúcar (32), embora no Mato Grosso não tenham se destacado entre os principais multiplicadores de emprego, no resto do Brasil estiveram entre os mais importantes, sendo responsáveis pela geração de 14,82; 9,7 e 5,8 empregos indiretos, respectivamente. Os três setores, entretanto, perdem a posição relativa na geração de empregos quando se considera endogenamente o consumo das famílias. 
Tabela 24. Multiplicadores de emprego tipos I e II para o resto do Brasil.

\begin{tabular}{|c|c|c|c|c|c|}
\hline & & Ordem & $\mathrm{I}$ & Ordem & II \\
\hline 1 & Cana-de-açúcar & 44 & 1,22 & 44 & 1,89 \\
\hline 2 & Soja & 38 & 1,51 & 41 & 2,56 \\
\hline 3 & Milho & 49 & 1,13 & 50 & 1,31 \\
\hline 4 & Fruticultura & 47 & 1,18 & 47 & 1,62 \\
\hline 5 & Outras culturas & 46 & 1,18 & 46 & 1,63 \\
\hline 6 & Aves & 40 & 1,35 & 48 & 1,61 \\
\hline 7 & Bovinos & 34 & 1,71 & 39 & 2,70 \\
\hline 8 & Suínos & 22 & 2,46 & 33 & 3,52 \\
\hline 9 & Outros pecuária & 27 & 1,97 & 37 & 3,01 \\
\hline 10 & Extrativismo vegetal & 50 & 1,10 & 49 & 1,47 \\
\hline 11 & Silvicultura & 48 & 1,17 & 45 & 1,80 \\
\hline 12 & Extrativismo animal (Pesca) & 29 & 1,89 & 25 & 7,40 \\
\hline 13 & Extrativismo mineral & 23 & 2,35 & 20 & 8,58 \\
\hline 14 & Siderurgia & 20 & 2,82 & 26 & 7,40 \\
\hline 15 & Máquinas e Implementos agrícolas & 25 & 2,08 & 22 & 7,67 \\
\hline 16 & Outras máquinas e equipamentos & 26 & 2,07 & 27 & 6,98 \\
\hline 17 & Eletro-eletrônicos & 16 & 3,62 & 18 & 10,58 \\
\hline 18 & Peças e veículos & 12 & 4,29 & 17 & 12,47 \\
\hline 19 & Madeira e mobiliário & 30 & 1,87 & 34 & 3,27 \\
\hline 20 & Celulose, papel e gráfica & 19 & 2,93 & 24 & 7,47 \\
\hline 21 & Químicos diversos & 17 & 3,06 & 19 & 9,25 \\
\hline 22 & Álcool & 5 & 14,66 & 3 & 32,62 \\
\hline 23 & Refino do Petróleo & 2 & 22,31 & 1 & 105,04 \\
\hline 24 & Adubos e fertilizantes & 10 & 5,74 & 8 & 19,67 \\
\hline 25 & Farmácia e veterinária & 13 & 4,24 & 14 & 13,23 \\
\hline 26 & Indústria têxtil e calçadista & 28 & 1,97 & 35 & 3,14 \\
\hline 27 & Indústria do café & 4 & 15,82 & 5 & 25,08 \\
\hline 28 & Beneficiamento de produtos vegetais & 8 & 8,23 & 13 & 13,24 \\
\hline 29 & Abate de outros animais & 3 & 16,65 & 6 & 23,72 \\
\hline 30 & Abate de bovinos & 7 & 9,80 & 10 & 16,80 \\
\hline 31 & Indústria de laticínios & 6 & 10,27 & 9 & 19,36 \\
\hline 32 & Fabricação de açúcar & 9 & 6,78 & 12 & 13,25 \\
\hline 33 & Fabricação de óleos vegetais & 1 & 25,31 & 2 & 52,11 \\
\hline 34 & Rações & 11 & 4,79 & 21 & 8,17 \\
\hline 35 & Outros produtos alimentares & 14 & 4,19 & 23 & 7,53 \\
\hline 36 & Indústrias Diversas & 31 & 1,81 & 30 & 3,97 \\
\hline 37 & S.I.U.P & 18 & 3,03 & 7 & 19,80 \\
\hline 38 & Construção civil & 37 & 1,55 & 32 & 3,70 \\
\hline 39 & Comércio & 45 & 1,20 & 42 & 2,23 \\
\hline 40 & Transporte rodoviário & 41 & 1,34 & 40 & 2,64 \\
\hline 41 & Transporte aéreo & 15 & 3,73 & 15 & 12,74 \\
\hline 42 & Transporte ferroviário & 33 & 1,72 & 29 & 5,01 \\
\hline 43 & Transporte aquaviário & 39 & 1,46 & 36 & 3,10 \\
\hline 44 & Atividades auxiliares dos transportes & 36 & 1,56 & 31 & 3,92 \\
\hline 45 & Comunicações & 24 & 2,29 & 11 & 13,94 \\
\hline 46 & Instituições financeiras & 21 & 2,77 & 16 & 12,60 \\
\hline 47 & Serviços prestados às famílias & 42 & 1,25 & 43 & 2,07 \\
\hline 48 & Serviços prestados às empresas & 43 & 1,25 & 38 & 2,94 \\
\hline 49 & Aluguel de imóveis & 32 & 1,75 & 4 & 28,88 \\
\hline 50 & Administração pública & 35 & 1,63 & 28 & 5,23 \\
\hline 51 & Serviços privados não mercantis & 51 & 1,01 & 51 & 1,24 \\
\hline
\end{tabular}




\subsubsection{Geração de renda}

A capacidade de geração de renda em valores absolutos depende da quantidade de pessoas ocupadas e do nível dos salários pagos pelo próprio setor e daqueles diretamente relacionados à ele. Os dados referentes à geração de renda total para a variação de um milhão de Reais da demanda final, tanto do Mato Grosso quanto do resto do Brasil, são apresentados na Tabela 25 e mostram que, de um modo geral, os setores primários (agricultura) têm uma baixa geração de renda total quando comparados aos demais.

Os setores responsáveis pelas maiores gerações de renda total na economia, tanto do Mato Grosso quanto do resto do Brasil, encontram-se entre os terciários (serviços), a saber: Serviços privados não mercantis (51), Administração pública (50), Instituições financeiras (46), Serviços prestados à empresas (48) e Serviços prestados à famílias (47). Dentre estes, apenas o setor Serviços privados não mercantis (51) encontrou-se entre os principais geradores de emprego, uma vez que se trata de um setor que emprega muita gente à baixos salários, e os demais, possivelmente são setores que empregam relativamente poucas pessoas com maiores salários. 
Tabela 25. Geração de renda total para a variação de um milhão de reais da demanda final.

\begin{tabular}{|c|c|c|c|c|c|}
\hline & & & & Restc & \\
\hline & Setor & Ordem & total & Ordem & total \\
\hline 1 & Cana-de-açúcar & 33 & 550 & 30 & 442 \\
\hline 2 & Soja & 47 & 451 & 24 & 467 \\
\hline 3 & Milho & 37 & 535 & 17 & 531 \\
\hline 4 & Fruticultura & 44 & 496 & 46 & 368 \\
\hline 5 & Outras culturas & 46 & 488 & 47 & 359 \\
\hline 6 & Aves & 32 & 561 & 42 & 392 \\
\hline 7 & Bovinos & 42 & 498 & 35 & 419 \\
\hline 8 & Suínos & 10 & 680 & 29 & 447 \\
\hline 9 & Outros pecuária & 26 & 590 & 37 & 413 \\
\hline 10 & Extrativismo vegetal & 49 & 441 & 49 & 301 \\
\hline 11 & Silvicultura & 34 & 547 & 44 & 376 \\
\hline 12 & Extrativismo animal (Pesca) & 50 & 435 & 50 & 289 \\
\hline 13 & Extrativismo mineral & 35 & 544 & 34 & 430 \\
\hline 14 & Siderurgia & 24 & 601 & 26 & 459 \\
\hline 15 & Máquinas e Implementos agrícolas & 7 & 767 & 6 & 667 \\
\hline 16 & Outras máquinas e equipamentos & 19 & 641 & 21 & 491 \\
\hline 17 & Eletro-eletrônicos & 22 & 624 & 32 & 434 \\
\hline 18 & Peças e veículos & 8 & 730 & 28 & 454 \\
\hline 19 & Madeira e mobiliário & 29 & 571 & 15 & 547 \\
\hline 20 & Celulose, papel e gráfica & 6 & 795 & 13 & 569 \\
\hline 21 & Químicos diversos & 38 & 535 & 36 & 418 \\
\hline 22 & Álcool & 40 & 514 & 39 & 403 \\
\hline 23 & Refino do Petróleo & 36 & 536 & 48 & 307 \\
\hline 24 & Adubos e fertilizantes & 21 & 630 & 33 & 431 \\
\hline 25 & Farmácia e veterinária & 23 & 611 & 31 & 441 \\
\hline 26 & Indústria têxtil e calçadista & 18 & 643 & 19 & 500 \\
\hline 27 & Indústria do café & 45 & 492 & 45 & 373 \\
\hline 28 & Beneficiamento de produtos vegetais & 39 & 524 & 38 & 408 \\
\hline 29 & Abate de outros animais & 31 & 564 & 25 & 461 \\
\hline 30 & Abate de bovinos & 43 & 496 & 27 & 456 \\
\hline 31 & Indústria de laticínios & 28 & 577 & 40 & 398 \\
\hline 32 & Fabricação de açúcar & 25 & 598 & 20 & 499 \\
\hline 33 & Fabricação de óleos vegetais & 48 & 449 & 41 & 398 \\
\hline 34 & Rações & 27 & 584 & 22 & 486 \\
\hline 35 & Outros produtos alimentares & 30 & 569 & 23 & 482 \\
\hline 36 & Indústrias Diversas & 17 & 653 & 18 & 511 \\
\hline 37 & S.I.U.P & 11 & 676 & 16 & 545 \\
\hline 38 & Construção civil & 41 & 511 & 43 & 377 \\
\hline 39 & Comércio & 20 & 631 & 7 & 646 \\
\hline 40 & Transporte rodoviário & 15 & 661 & 10 & 592 \\
\hline 41 & Transporte aéreo & 13 & 669 & 9 & 594 \\
\hline 42 & Transporte ferroviário & 12 & 673 & 11 & 584 \\
\hline 43 & Transporte aquaviário & 14 & 664 & 12 & 580 \\
\hline 44 & Atividades auxiliares dos transportes & 9 & 722 & 8 & 640 \\
\hline 45 & Comunicações & 16 & 659 & 14 & 549 \\
\hline 46 & Instituições financeiras & 3 & 927 & 3 & 817 \\
\hline 47 & Serviços prestados às famílias & 5 & 820 & 5 & 738 \\
\hline 48 & Serviços prestados às empresas & 4 & 888 & 4 & 753 \\
\hline 49 & Aluguel de imóveis & 51 & 378 & 51 & 238 \\
\hline 50 & Administração pública & 2 & 1303 & 2 & 1155 \\
\hline 51 & Serviços privados não mercantis & 1 & 1414 & 1 & 1342 \\
\hline
\end{tabular}


A Tabela 26 apresenta os valores da geração de renda total desagregada em renda direta, indireta e induzida. De um modo geral os setores primários tendem a apresentar uma geração de renda direta baixa quando comparada com a geração de renda indireta e induzida pelo consumo das famílias. Ao comparar com a geração de empregos diretos e indiretos, verifica-se que estes setores tendem a apresentar maior geração de empregos diretos quando comparados com a geração de empregos indiretos, o que sugere que possivelmente a produtividade do trabalho em alguns setores primários seja menor do que a produtividade do trabalho nos setores ligados aos mesmos, uma vez que geram relativemente muitos empregos e baixos salários. Porém, o setor Soja (2) não apresenta este mesmo comportamento, pois apesar de gerar uma baixa quantidade de salários diretamente, também gera poucos empregos diretamente, tendo um maior efeito em termos de geração indireta de empregos e renda, nas atividades fornecedoras de insumos. 
Tabela 26. Geração de renda direta, indireta e induzida para a variação de um milhão de reais da demanda final.

\begin{tabular}{|c|c|c|c|c|c|c|c|}
\hline & & \multicolumn{3}{|c|}{ Mato Grosso } & \multicolumn{3}{|c|}{ Resto do Brasil } \\
\hline & & Dir. & Indir. & Indu. & Dir. & Indir. & Indu. \\
\hline 1 & Cana-de-açúcar & 116 & 133 & 301 & 116 & 95 & 231 \\
\hline 2 & Soja & 14 & 170 & 267 & 100 & 139 & 228 \\
\hline 3 & Milho & 82 & 179 & 274 & 138 & 156 & 237 \\
\hline 4 & Fruticultura & 75 & 112 & 308 & 75 & 70 & 222 \\
\hline 5 & Outras culturas & 75 & 103 & 310 & 75 & 61 & 223 \\
\hline 6 & Aves & 75 & 187 & 298 & 27 & 147 & 218 \\
\hline 7 & Bovinos & 70 & 137 & 291 & 87 & 104 & 228 \\
\hline 8 & Suínos & 201 & 164 & 314 & 83 & 133 & 231 \\
\hline 9 & Outros pecuária & 146 & 136 & 307 & 84 & 102 & 228 \\
\hline 10 & Extrativismo vegetal & 48 & 82 & 312 & 48 & 38 & 216 \\
\hline 11 & Silvicultura & 106 & 100 & 341 & 106 & 41 & 229 \\
\hline 12 & Extrativismo animal (Pesca) & 27 & 98 & 310 & 27 & 51 & 212 \\
\hline 13 & Extrativismo mineral & 113 & 119 & 312 & 98 & 112 & 220 \\
\hline 14 & Siderurgia & 130 & 177 & 294 & 92 & 160 & 207 \\
\hline 15 & Máquinas e Implementos agrícolas & 313 & 135 & 319 & 313 & 97 & 256 \\
\hline 16 & Outras máquinas e equipamentos & 166 & 151 & 323 & 166 & 98 & 227 \\
\hline 17 & Eletro-eletrônicos & 99 & 234 & 291 & 99 & 142 & 193 \\
\hline 18 & Peças e veículos & 155 & 267 & 309 & 111 & 151 & 192 \\
\hline 19 & Madeira e mobiliário & 126 & 136 & 310 & 167 & 132 & 248 \\
\hline 20 & Celulose, papel e gráfica & 152 & 323 & 320 & 143 & 197 & 230 \\
\hline 21 & Químicos diversos & 79 & 175 & 281 & 104 & 117 & 198 \\
\hline 22 & Álcool & 53 & 169 & 293 & 53 & 136 & 215 \\
\hline 23 & Refino do Petróleo & 92 & 169 & 275 & 21 & 108 & 178 \\
\hline 24 & Adubos e fertilizantes & 95 & 271 & 264 & 95 & 160 & 176 \\
\hline 25 & Farmácia e veterinária & 101 & 202 & 308 & 101 & 128 & 212 \\
\hline 26 & Indústria têxtil e calçadista & 180 & 161 & 302 & 114 & 162 & 224 \\
\hline 27 & Indústria do café & 37 & 153 & 302 & 37 & 119 & 216 \\
\hline 28 & Beneficiamento de produtos vegetais & 60 & 172 & 293 & 60 & 135 & 214 \\
\hline 29 & Abate de outros animais & 46 & 238 & 280 & 51 & 185 & 225 \\
\hline 30 & Abate de bovinos & 26 & 193 & 277 & 51 & 179 & 226 \\
\hline 31 & Indústria de laticínios & 203 & 8 & 365 & 49 & 149 & 200 \\
\hline 32 & Fabricação de açúcar & 97 & 224 & 277 & 87 & 191 & 220 \\
\hline 33 & Fabricação de óleos vegetais & 17 & 174 & 257 & 17 & 174 & 206 \\
\hline 34 & Rações & 94 & 202 & 288 & 94 & 169 & 223 \\
\hline 35 & Outros produtos alimentares & 99 & 189 & 281 & 99 & 163 & 221 \\
\hline 36 & Indústrias Diversas & 124 & 223 & 306 & 124 & 162 & 225 \\
\hline 37 & S.I.U.P & 183 & 181 & 312 & 187 & 119 & 239 \\
\hline 38 & Construção civil & 94 & 115 & 302 & 69 & 92 & 215 \\
\hline 39 & Comércio & 145 & 184 & 303 & 244 & 116 & 286 \\
\hline 40 & Transporte rodoviário & 209 & 144 & 309 & 209 & 132 & 251 \\
\hline 41 & Transporte aéreo & 191 & 176 & 302 & 191 & 158 & 244 \\
\hline 42 & Transporte ferroviário & 191 & 134 & 348 & 191 & 121 & 272 \\
\hline 43 & Transporte aquaviário & 191 & 149 & 324 & 191 & 136 & 253 \\
\hline 44 & Atividades auxiliares dos transportes & 249 & 133 & 341 & 249 & 120 & 271 \\
\hline 45 & Comunicações & 247 & 53 & 359 & 247 & 52 & 250 \\
\hline 46 & Instituições financeiras & 388 & 144 & 395 & 388 & 124 & 306 \\
\hline 47 & Serviços prestados às famílias & 348 & 105 & 367 & 335 & 104 & 299 \\
\hline 48 & Serviços prestados às empresas & 383 & 115 & 390 & 352 & 101 & 300 \\
\hline 49 & Aluguel de imóveis & 12 & 12 & 354 & 17 & 8 & 213 \\
\hline 50 & Administração pública & 774 & 82 & 446 & 693 & 95 & 368 \\
\hline 51 & Serviços privados não mercantis & 926 & 17 & 471 & 915 & 17 & 410 \\
\hline
\end{tabular}


Os resultados para os multiplicadores de renda apresentados na Tabela 27 são interpretados da seguinte forma: o multiplicador tipo I do setor Soja (2) indica que são gerados $\mathrm{R} \$ 13,53$ de renda (salário líquido) na economia como um todo para cada um Real de renda gerada na própria atividade no estado do Mato Grosso, considerando-se os efeitos diretos e indiretos. A interpretação dos valores para o multiplicador tipo II é a mesma, porém este indica que para cada um Real de renda gerada no setor Soja (2) do Mato Grosso, são gerados R \$33,23 de renda na economia como um todo, considerandose os efeitos diretos, indiretos e induzidos. Note que este setor do Mato Grosso é o responsável pelo maior efeito multiplicador de renda na economia quando comparado com os demais setores pertencentes à mesma região, uma característica intrínseca de setores intensivos em capital, com maior grau de mecanização.

No entanto, outros setores da região são também identificados como importantes multiplicadores de renda na economia. O setor Fabricação de óleos vegetais (33) gera $\mathrm{R} \$ 11,03$ de renda destacando-se como o segundo maior multiplicador de renda, e ao considerar o consumo das famílias endogenamente este valor sobe para $\mathrm{R} \$$ 25,85 , porém, perde ligeiramente sua participação relativa quando em comparação com as outras atividades.

O setor Abate de bovinos (30) destaca-se como o terceiro maior multiplicador de renda, respondendo por $\mathrm{R} \$ 8,34$ gerados na economia a cada um Real de renda gerada na própria atividade. Em seguida aparecem os setores Abate de outros animais (29), Indústria do café (27), Extrativismo Animal (12), Álcool (22), Beneficiamento de produtos vegetais (28) e Adubos e fertilizantes (24), como importantes multiplicadores de renda. Entretanto, todos estes perdem ligeiramente suas posições relativas quando considerado o efeito induzido do consumo das famílias, ou seja, a renda adicional oriunda da geração de empregos diretos e indiretos por estes setores não é suficientemente elevada a ponto de aumentar significativamente os empregos gerados pelo efeito induzido pelo consumo das famílias. Observa-se que todos os setores matogrossenses responsáveis pelos maiores efeitos multiplicadores de renda na economia também estão diretamente relacionados àagropecuária. 
A maioria dos setores primários (atividades agrícolas) do Mato Grosso ganham importância relativa na geração de renda quando se considera o efeito induzido do consumo das famílias. Já no setor secundário (indústria) apenas a Indústria têxtil e calçadista (26) e a Indústria de laticínios (31) ganham importância relativa nas mesmas condições. No caso do setor terciário (serviços), isto é verificado no Transporte ferroviário (42), Comunicações (45) e Aluguel de imóveis (49). 
Tabela 27. Multiplicadores de renda tipos I e II para o Mato Grosso.

\begin{tabular}{|c|c|c|c|c|c|}
\hline & & Ordem & $\mathrm{I}$ & Ordem & II \\
\hline 1 & Cana-de-açúcar & 29 & 2,14 & 29 & 4,73 \\
\hline 2 & Soja & 1 & 13,53 & 1 & 33,23 \\
\hline 3 & Milho & 14 & 3,18 & 16 & 6,51 \\
\hline 4 & Fruticultura & 24 & 2,49 & 15 & 6,59 \\
\hline 5 & Outras culturas & 25 & 2,37 & 17 & 6,48 \\
\hline 6 & Aves & 10 & 3,48 & 11 & 7,44 \\
\hline 7 & Bovinos & 18 & 2,95 & 12 & 7,10 \\
\hline 8 & Suínos & 39 & 1,82 & 41 & 3,38 \\
\hline 9 & Outros pecuária & 35 & 1,93 & 34 & 4,03 \\
\hline 10 & Extrativismo vegetal & 23 & 2,72 & 9 & 9,28 \\
\hline 11 & Silvicultura & 34 & 1,94 & 27 & 5,15 \\
\hline 12 & Extrativismo animal (Pesca) & 6 & 4,66 & 5 & 16,24 \\
\hline 13 & Extrativismo mineral & 31 & 2,05 & 28 & 4,81 \\
\hline 14 & Siderurgia & 26 & 2,36 & 31 & 4,63 \\
\hline 15 & Máquinas e Implementos agrícolas & 44 & 1,43 & 46 & 2,45 \\
\hline 16 & Outras máquinas e equipamentos & 37 & 1,91 & 35 & 3,85 \\
\hline 17 & Eletro-eletrônicos & 11 & 3,37 & 18 & 6,32 \\
\hline 18 & Peças e veículos & 22 & 2,72 & 30 & 4,72 \\
\hline 19 & Madeira e mobiliário & 30 & 2,08 & 32 & 4,55 \\
\hline 20 & Celulose, papel e gráfica & 16 & 3,12 & 26 & 5,22 \\
\hline 21 & Químicos diversos & 13 & 3,21 & 13 & 6,76 \\
\hline 22 & Álcool & 7 & 4,20 & 8 & 9,76 \\
\hline 23 & Refino do Petróleo & 20 & 2,83 & 22 & 5,79 \\
\hline 24 & Adubos e fertilizantes & 9 & 3,86 & 14 & 6,63 \\
\hline 25 & Farmácia e veterinária & 17 & 3,00 & 21 & 6,06 \\
\hline 26 & Indústria têxtil e calçadista & 38 & 1,90 & 37 & 3,57 \\
\hline 27 & Indústria do café & 5 & 5,11 & 6 & 13,21 \\
\hline 28 & Beneficiamento de produtos vegetais & 8 & 3,87 & 10 & 8,75 \\
\hline 29 & Abate de outros animais & 4 & 6,12 & 7 & 12,13 \\
\hline 30 & Abate de bovinos & 3 & 8,34 & 4 & 18,92 \\
\hline 31 & Indústria de laticínios & 50 & 1,04 & 44 & 2,83 \\
\hline 32 & Fabricação de açúcar & 12 & 3,31 & 20 & 6,16 \\
\hline 33 & Fabricação de óleos vegetais & 2 & 11,03 & 3 & 25,85 \\
\hline 34 & Rações & 15 & 3,15 & 19 & 6,21 \\
\hline 35 & Outros produtos alimentares & 19 & 2,91 & 23 & 5,75 \\
\hline 36 & Indústrias Diversas & 21 & 2,79 & 25 & 5,26 \\
\hline 37 & S.I.U.P & 33 & 1,99 & 36 & 3,69 \\
\hline 38 & Construção civil & 28 & 2,22 & 24 & 5,43 \\
\hline 39 & Comércio & 27 & 2,27 & 33 & 4,37 \\
\hline 40 & Transporte rodoviário & 42 & 1,69 & 42 & 3,17 \\
\hline 41 & Transporte aéreo & 36 & 1,92 & 39 & 3,50 \\
\hline 42 & Transporte ferroviário & 41 & 1,70 & 38 & 3,52 \\
\hline 43 & Transporte aquaviário & 40 & 1,78 & 40 & 3,48 \\
\hline 44 & Atividades auxiliares dos transportes & 43 & 1,53 & 43 & 2,90 \\
\hline 45 & Comunicações & 48 & 1,22 & 45 & 2,67 \\
\hline 46 & Instituições financeiras & 45 & 1,37 & 47 & 2,39 \\
\hline 47 & Serviços prestados às famílias & 46 & 1,30 & 48 & 2,36 \\
\hline 48 & Serviços prestados às empresas & 47 & 1,30 & 49 & 2,32 \\
\hline 49 & Aluguel de imóveis & 32 & 2,00 & 2 & 31,73 \\
\hline 50 & Administração pública & 49 & 1,11 & 50 & 1,68 \\
\hline 51 & Serviços privados não mercantis & 51 & 1,02 & 51 & 1,53 \\
\hline
\end{tabular}

Analisando-se os valores calculados para os multiplicadores de renda dos setores pertencentes ao resto do Brasil, apresentados na Tabela 28, verifica-se que os 
principais setores responsáveis pela multiplicação de renda na economia encontram-se entre as atividades do setor secundário (indústria), porém, diretamente relacionados à agropecuária, em outras palavras, pertencentes àcadeia do agronegócio. A Fabricação de óleos vegetais (33) destaca-se como o setor de maior efeito multiplicador de renda na economia, gerando $\mathrm{R} \$ 10,04$ de salários na economia como um todo para cada um Real gerado na própria atividade, e considerando o efeito induzido pelo consumo das famílias endogeneizado são gerados $\mathrm{R} \$ 21,89$ em renda.

Entretanto, o setor classificado como o de segundo maior efeito multiplicador de renda na economia encontra-se entre as atividades primárias (agricultura). Trata-se do setor Aves (6) responsável pela geração de $\mathrm{R} \$$ 5,54 de renda na economia para cada um Real gerado na própria atividade, e considerando o efeito induzido do consumo das famílias este valor sobe para $\mathrm{R} \$ 13,76$, mantendo porém, sua posição relativa em relação aos demais setores. 
Tabela 28. Multiplicadores de renda tipos I e II para o Resto do Brasil.

\begin{tabular}{|c|c|c|c|c|c|}
\hline & & Ordem & $\mathrm{I}$ & Ordem & II \\
\hline 1 & Cana-de-açúcar & 32 & 1,82 & 34 & 3,80 \\
\hline 2 & Soja & 19 & 2,40 & 23 & 4,69 \\
\hline 3 & Milho & 28 & 2,13 & 33 & 3,85 \\
\hline 4 & Fruticultura & 30 & 1,93 & 19 & 4,89 \\
\hline 5 & Outras culturas & 33 & 1,81 & 22 & 4,77 \\
\hline 6 & Aves & 2 & 6,54 & 2 & 14,76 \\
\hline 7 & Bovinos & 26 & 2,19 & 21 & 4,82 \\
\hline 8 & Suínos & 16 & 2,60 & 15 & 5,39 \\
\hline 9 & Outros pecuária & 25 & 2,21 & 18 & 4,94 \\
\hline 10 & Extrativismo vegetal & 34 & 1,80 & 12 & 6,33 \\
\hline 11 & Silvicultura & 44 & 1,39 & 35 & 3,54 \\
\hline 12 & Extrativismo animal (Pesca) & 11 & 2,90 & 5 & 10,80 \\
\hline 13 & Extrativismo mineral & 27 & 2,14 & 25 & 4,39 \\
\hline 14 & Siderurgia & 13 & 2,73 & 17 & 4,97 \\
\hline 15 & Máquinas e Implementos agrícolas & 46 & 1,31 & 48 & 2,13 \\
\hline 16 & Outras máquinas e equipamentos & 40 & 1,59 & 40 & 2,95 \\
\hline 17 & Eletro-eletrônicos & 17 & 2,44 & 26 & 4,38 \\
\hline 18 & Peças e veículos & 21 & 2,37 & 30 & 4,09 \\
\hline 19 & Madeira e mobiliário & 35 & 1,79 & 36 & 3,27 \\
\hline 20 & Celulose, papel e gráfica & 20 & 2,38 & 32 & 3,99 \\
\hline 21 & Químicos diversos & 29 & 2,13 & 31 & 4,04 \\
\hline 22 & Álcool & 8 & 3,57 & 10 & 7,65 \\
\hline 23 & Refino do Petróleo & 3 & 6,10 & 3 & 14,51 \\
\hline 24 & Adubos e fertilizantes & 14 & 2,69 & 24 & 4,55 \\
\hline 25 & Farmácia e veterinária & 24 & 2,27 & 28 & 4,37 \\
\hline 26 & Indústria têxtil e calçadista & 18 & 2,42 & 27 & 4,38 \\
\hline 27 & Indústria do café & 6 & 4,20 & 6 & 10,01 \\
\hline 28 & Beneficiamento de produtos vegetais & 9 & 3,25 & 11 & 6,81 \\
\hline 29 & Abate de outros animais & 4 & 4,62 & 7 & 9,00 \\
\hline 30 & Abate de bovinos & 5 & 4,52 & 8 & 8,96 \\
\hline 31 & Indústria de laticínios & 7 & 4,04 & 9 & 8,11 \\
\hline 32 & Fabricação de açúcar & 10 & 3,19 & 13 & 5,71 \\
\hline 33 & Fabricação de óleos vegetais & 1 & 11,04 & 1 & 22,89 \\
\hline 34 & Rações & 12 & 2,80 & 16 & 5,18 \\
\hline 35 & Outros produtos alimentares & 15 & 2,64 & 20 & 4,88 \\
\hline 36 & Indústrias Diversas & 23 & 2,31 & 29 & 4,12 \\
\hline 37 & S.I.U.P & 37 & 1,64 & 41 & 2,91 \\
\hline 38 & Construção civil & 22 & 2,33 & 14 & 5,43 \\
\hline 39 & Comércio & 42 & 1,47 & 43 & 2,64 \\
\hline 40 & Transporte rodoviário & 39 & 1,63 & 42 & 2,84 \\
\hline 41 & Transporte aéreo & 31 & 1,83 & 37 & 3,11 \\
\hline 42 & Transporte ferroviário & 38 & 1,63 & 38 & 3,06 \\
\hline 43 & Transporte aquaviário & 36 & 1,71 & 39 & 3,04 \\
\hline 44 & Atividades auxiliares dos transportes & 41 & 1,48 & 44 & 2,57 \\
\hline 45 & Comunicações & 49 & 1,21 & 45 & 2,23 \\
\hline 46 & Instituições financeiras & 45 & 1,32 & 49 & 2,11 \\
\hline 47 & Serviços prestados às famílias & 47 & 1,31 & 46 & 2,20 \\
\hline 48 & Serviços prestados às empresas & 48 & 1,29 & 47 & 2,14 \\
\hline 49 & Aluguel de imóveis & 43 & 1,47 & 4 & 13,90 \\
\hline 50 & Administração pública & 50 & 1,14 & 50 & 1,67 \\
\hline 51 & Serviços privados não mercantis & 51 & 1,02 & 51 & 1,47 \\
\hline
\end{tabular}




\subsubsection{Multiplicador da produção}

Os resultados para os multiplicadores de produção apresentados na Tabela 29 são interpretados da seguinte forma: o multiplicador tipo I do setor Soja (2) indica que são gerados $\mathrm{R} \$ 1,34$ de produção na economia como um todo para cada um Real de produção gerada na própria atividade, considerando-se os efeitos diretos e indiretos. A interpretação dos valores para o multiplicador tipo II é a mesma, porém este indica que para cada um Real de produção gerada no setor Soja (2) do Mato Grosso, são gerados $\mathrm{R} \$ 4,23$ de produção na economia como um todo, considerando-se os efeitos diretos, indiretos e induzidos. Note que este setor perde sua posição relativa ao considerar o efeito induzido pelo consumo das famílias endogeneizado, entretanto, sem considerar este efeito encontra-se na décima terceira posição em termos de maior efeito multiplicador de produção na economia.

Dentre os setores produtivos do Mato Grosso, aqueles com maior efeito multiplicador de produção encontram-se no setor secundário, como por exemplo, Abate de outros animais (29), Abate de bovinos (30), Fabricação de óleos vegetais (33), Adubos e fertilizantes (24), Fabricação de açúcar (32), Outros produtos alimentares (35), Rações (34) e Indústria do café (27), porém, todos pertencentes àcadeia do agronegócio. Alguns dos setores com os maiores efeitos multiplicadores da produção encontram-se no setor primário, a saber: Soja (2), conforme discutido no parágrafo anterior, Milho (3), Aves (6) e Suínos (8). Entretanto, com exceção dos setores Aves (6) e Rações (34),

todos estes perdem suas posições relativas em termos de efeito multiplicador da produção quando considerado o efeito induzido pelo consumo das famílias endogeneizado.

Alguns setores chamam atenção pela grande perda de posição relativa em termos de efeito multiplicador da produção quando considerado o efeito induzido pelo consumo das famílias, enquanto outros setores chamam atenção pelo considerável ganho de posição relativa perante esta mesma situação. Note que os setores Indústria do café (27), Abate de outros animais (29) e Abate de bovinos (30) passam das posições relativas 10,1 e 2 para as posições 50,40 e 41 , respectivamente, e que os setores 
Indústria de laticínios (31) e Aluguel de imóveis (49) passam das posições relativas 51, e 50 para as posições 1 e 2 , respectivamente. 
Tabela 29. Multiplicadores de produção tipos I e II para o Mato Grosso.

\begin{tabular}{|c|c|c|c|c|c|}
\hline & & Ordem & $\mathrm{I}$ & Ordem & II \\
\hline 1 & Cana-de-açúcar & 30 & 2,03 & 4 & 5,28 \\
\hline 2 & Soja & 13 & 2,34 & 47 & 5,23 \\
\hline 3 & Milho & 9 & 2,43 & 26 & 5,39 \\
\hline 4 & Fruticultura & 35 & 1,86 & 18 & 5,19 \\
\hline 5 & Outras culturas & 39 & 1,79 & 25 & 5,13 \\
\hline 6 & Aves & 6 & 2,55 & 5 & 5,78 \\
\hline 7 & Bovinos & 24 & 2,14 & 22 & 5,28 \\
\hline 8 & Suínos & 12 & 2,35 & 48 & 5,74 \\
\hline 9 & Outros pecuária & 25 & 2,11 & 23 & 5,43 \\
\hline 10 & Extrativismo vegetal & 44 & 1,61 & 19 & 4,97 \\
\hline 11 & Silvicultura & 43 & 1,68 & 16 & 5,36 \\
\hline 12 & Extrativismo animal (Pesca) & 42 & 1,71 & 13 & 5,06 \\
\hline 13 & Extrativismo mineral & 41 & 1,72 & 24 & 5,10 \\
\hline 14 & Siderurgia & 20 & 2,18 & 12 & 5,37 \\
\hline 15 & Máquinas e Implementos agrícolas & 33 & 1,90 & 15 & 5,35 \\
\hline 16 & Outras máquinas e equipamentos & 34 & 1,90 & 17 & 5,39 \\
\hline 17 & Eletro-eletrônicos & 11 & 2,35 & 33 & 5,49 \\
\hline 18 & Peças e veículos & 16 & 2,30 & 28 & 5,64 \\
\hline 19 & Madeira e mobiliário & 31 & 2,00 & 49 & 5,35 \\
\hline 20 & Celulose, papel e gráfica & 21 & 2,17 & 34 & 5,64 \\
\hline 21 & Químicos diversos & 15 & 2,32 & 36 & 5,36 \\
\hline 22 & Álcool & 18 & 2,23 & 11 & 5,39 \\
\hline 23 & Refino do Petróleo & 17 & 2,24 & 21 & 5,20 \\
\hline 24 & Adubos e fertilizantes & 4 & 2,63 & 43 & 5,48 \\
\hline 25 & Farmácia e veterinária & 23 & 2,14 & 42 & 5,47 \\
\hline 26 & Indústria têxtil e calçadista & 27 & 2,09 & 10 & 5,35 \\
\hline 27 & Indústria do café & 10 & 2,41 & 50 & 5,67 \\
\hline 28 & Beneficiamento de produtos vegetais & 14 & 2,34 & 32 & 5,51 \\
\hline 29 & Abate de outros animais & 1 & 2,84 & 40 & 5,86 \\
\hline 30 & Abate de bovinos & 2 & 2,81 & 41 & 5,81 \\
\hline 31 & Indústria de laticínios & 51 & 1,06 & 1 & 5,01 \\
\hline 32 & Fabricação de açúcar & 5 & 2,59 & 45 & 5,58 \\
\hline 33 & Fabricação de óleos vegetais & 3 & 2,78 & 29 & 5,56 \\
\hline 34 & Rações & 8 & 2,44 & 7 & 5,55 \\
\hline 35 & Outros produtos alimentares & 7 & 2,49 & 39 & 5,53 \\
\hline 36 & Indústrias Diversas & 26 & 2,11 & 37 & 5,41 \\
\hline 37 & S.I.U.P & 32 & 1,98 & 14 & 5,35 \\
\hline 38 & Construção civil & 37 & 1,84 & 38 & 5,11 \\
\hline 39 & Comércio & 22 & 2,17 & 30 & 5,44 \\
\hline 40 & Transporte rodoviário & 29 & 2,05 & 3 & 5,38 \\
\hline 41 & Transporte aéreo & 19 & 2,19 & 35 & 5,46 \\
\hline 42 & Transporte ferroviário & 36 & 1,85 & 27 & 5,60 \\
\hline 43 & Transporte aquaviário & 28 & 2,05 & 20 & 5,56 \\
\hline 44 & Atividades auxiliares dos transportes & 38 & 1,83 & 46 & 5,51 \\
\hline 45 & Comunicações & 48 & 1,27 & 9 & 5,15 \\
\hline 46 & Instituições financeiras & 45 & 1,48 & 44 & 5,75 \\
\hline 47 & Serviços prestados às famílias & 40 & 1,76 & 31 & 5,72 \\
\hline 48 & Serviços prestados às empresas & 46 & 1,46 & 6 & 5,67 \\
\hline 49 & Aluguel de imóveis & 50 & 1,09 & 2 & 4,91 \\
\hline 50 & Administração pública & 47 & 1,36 & 8 & 6,18 \\
\hline 51 & Serviços privados não mercantis & 49 & 1,11 & 51 & 6,20 \\
\hline
\end{tabular}

Analisando-se os valores calculados para os multiplicadores de produção dos setores pertencentes ao resto do Brasil, apresentados na Tabela 30, verifica-se que os principais setores responsáveis pela geração de produção na economia encontram-se 
entre as atividades do setor secundário (indústria), porém todos relacionados diretamente às atividades agrícolas, destacando-se o Abate de outros animais (29) como o setor de maior efeito multiplicador da produção na economia, gerando $\mathrm{R}$ \$1,62 de produção para cada um Real gerado na própria atividade, e considerando o efeito induzido pelo consumo das famílias endogeneizado são gerados $\mathrm{R}$ \$,04 de produção na economia como um todo para cada um Real gerado no próprio setor.

Todos estes setores destacados entre os de maior efeito multiplicador da produção perdem suas posições relativas quando considerado o efeito induzido pelo consumo das famílias. Em contrapartida, praticamente todos os setores de serviços ganham em suas posições relativas em termos de efeito multiplicador da produção, destacando-se os setores Administração pública (50) e Serviços privados não mercantis (51), que passam das posições 45 e 50 para as posições 2 e 1, respectivamente. Os outros três setores que ganham em termos de posições relativas são Milho (3), Máquinas e implementos agrícolas (15) e Madeira e mobiliário (19).

Deve-se destacar que o setor classificado como o de oitavo maior efeito multiplicador de produção na economia encontra-se entre as atividades primárias (agricultura). Trata-se do setor Aves (6), responsável pela geração de $\mathrm{R} \$ 1,21$ de produção na economia para cada um Real gerado na própria atividade, e considerando o efeito induzido pelo consumo das famílias endogeneizado este valor sobe para $\mathrm{R} \$ 3,57$, perdendo porém, sua posição relativa em relação aos demais setores. É interessante verificar que este setor se destacou como importante multiplicador tanto de produção quanto de renda na economia. 
Tabela 30. Multiplicadores de produção tipos I e II para o resto do Brasil.

\begin{tabular}{|c|c|c|c|c|c|}
\hline & & Ordem & $\mathrm{I}$ & Ordem & II \\
\hline 1 & Cana-de-açúcar & 35 & 1,70 & 35 & 4,19 \\
\hline 2 & Soja & 18 & 2,03 & 25 & 4,49 \\
\hline 3 & Milho & 13 & 2,16 & 10 & 4,72 \\
\hline 4 & Fruticultura & 41 & 1,52 & 45 & 3,93 \\
\hline 5 & Outras culturas & 43 & 1,46 & 46 & 3,86 \\
\hline 6 & Aves & 8 & 2,21 & 22 & 4,57 \\
\hline 7 & Bovinos & 29 & 1,85 & 31 & 4,31 \\
\hline 8 & Suínos & 19 & 2,00 & 24 & 4,50 \\
\hline 9 & Outros pecuária & 30 & 1,81 & 33 & 4,28 \\
\hline 10 & Extrativismo vegetal & 48 & 1,28 & 50 & 3,61 \\
\hline 11 & Silvicultura & 47 & 1,30 & 48 & 3,77 \\
\hline 12 & Extrativismo animal (Pesca) & 46 & 1,35 & 49 & 3,64 \\
\hline 13 & Extrativismo mineral & 40 & 1,61 & 43 & 3,99 \\
\hline 14 & Siderurgia & 12 & 2,18 & 28 & 4,42 \\
\hline 15 & Máquinas e Implementos agrícolas & 38 & 1,67 & 27 & 4,43 \\
\hline 16 & Outras máquinas e equipamentos & 37 & 1,67 & 38 & 4,12 \\
\hline 17 & Eletro-eletrônicos & 23 & 1,96 & 41 & 4,04 \\
\hline 18 & Peças e veículos & 17 & 2,03 & 40 & 4,11 \\
\hline 19 & Madeira e mobiliário & 26 & 1,90 & 20 & 4,58 \\
\hline 20 & Celulose, papel e gráfica & 14 & 2,09 & 21 & 4,57 \\
\hline 21 & Químicos diversos & 20 & 1,97 & 39 & 4,11 \\
\hline 22 & Álcool & 21 & 1,97 & 32 & 4,29 \\
\hline 23 & Refino do Petróleo & 25 & 1,93 & 47 & 3,85 \\
\hline 24 & Adubos e fertilizantes & 7 & 2,27 & 36 & 4,17 \\
\hline 25 & Farmácia e veterinária & 28 & 1,88 & 37 & 4,17 \\
\hline 26 & Indústria têxtil e calçadista & 10 & 2,20 & 18 & 4,62 \\
\hline 27 & Indústria do café & 11 & 2,20 & 23 & 4,54 \\
\hline 28 & Beneficiamento de produtos vegetais & 16 & 2,06 & 29 & 4,37 \\
\hline 29 & Abate de outros animais & 1 & 2,62 & 3 & 5,04 \\
\hline 30 & Abate de bovinos & 2 & 2,56 & 4 & 5,00 \\
\hline 31 & Indústria de laticínios & 5 & 2,30 & 26 & 4,46 \\
\hline 32 & Fabricação de açúcar & 4 & 2,32 & 11 & 4,71 \\
\hline 33 & Fabricação de óleos vegetais & 3 & 2,51 & 8 & 4,74 \\
\hline 34 & Rações & 9 & 2,21 & 19 & 4,62 \\
\hline 35 & Outros produtos alimentares & 6 & 2,28 & 15 & 4,67 \\
\hline 36 & Indústrias Diversas & 27 & 1,89 & 30 & 4,32 \\
\hline 37 & S.I.U.P & 39 & 1,63 & 34 & 4,22 \\
\hline 38 & Construção civil & 36 & 1,68 & 42 & 4,01 \\
\hline 39 & Comércio & 31 & 1,78 & 6 & 4,87 \\
\hline 40 & Transporte rodoviário & 24 & 1,95 & 16 & 4,66 \\
\hline 41 & Transporte aéreo & 15 & 2,09 & 9 & 4,73 \\
\hline 42 & Transporte ferroviário & 32 & 1,75 & 14 & 4,69 \\
\hline 43 & Transporte aquaviário & 22 & 1,96 & 13 & 4,69 \\
\hline 44 & Atividades auxiliares dos transportes & 33 & 1,73 & 17 & 4,66 \\
\hline 45 & Comunicações & 49 & 1,27 & 44 & 3,97 \\
\hline 46 & Instituições financeiras & 44 & 1,43 & 7 & 4,74 \\
\hline 47 & Serviços prestados às famílias & 34 & 1,72 & 5 & 4,95 \\
\hline 48 & Serviços prestados às empresas & 42 & 1,46 & 12 & 4,70 \\
\hline 49 & Aluguel de imóveis & 51 & 1,07 & 51 & 3,37 \\
\hline 50 & Administração pública & 45 & 1,42 & 2 & 5,40 \\
\hline 51 & Serviços privados não mercantis & 50 & 1,12 & 1 & 5,55 \\
\hline
\end{tabular}




\subsection{Indicadores econômicos para o setor da soja no estado do Mato Grosso}

Sabe-se, que de acordo com os clássicos Johnston e Mellor (1961), um dos papéis importantes a serem desempenhados pela agricultura no processo de crescimento econômico de um país é o de atrair ganhos cambiais com os quais os insumos críticos para o processo de desenvolvimento poderão ser adquiridos no exterior, e a soja, de acordo com a revisão de literatura, é o principal produto de exportação brasileira, e o principal estado produtor e exportador de soja atualmente no Brasil é o Mato Grosso.

Desta forma, dada a importância relativa do setor da soja na estrutura produtiva do estado do Mato Grosso, conforme sugerido na revisão de literatura e demonstrado empiricamente em resultados desta pesquisa, optou-se por calcular alguns indicadores adicionais objetivando enfatizar melhor a importância do setor em termos de suas exportações, como forma de atrair ganhos cambiais ao país, além de impactar positivamente a produção de diversos outros setores.

Então, foram calculados os impactos das exportações totais e das exportações de soja do estado, sobre a produção total, valor adicionado e geração de empregos, em todos os demais setores pertencentes às duas regiões em análise. Além disso, foi feita uma simulação de aumento em $10 \%$ das exportações de soja do estado, para verificar qual o impacto sobre as mesmas variáveis nos demais setores.

A Tabela 31 mostra os valores encontrados para as exportações do Mato Grosso no ano de 1999, agrupadas em três grandes grupos, destacando-se a soja, por representar 96\% das exportações do setor primário, e a fabricação de óleos vegetais, por representar $58 \%$ das exportações do setor secundário. 
Tabela 31. Exportações (em mil Reais) do Mato Grosso no ano de 1999.

\begin{tabular}{lc}
\hline \multicolumn{1}{c}{ Grupos de Setores } & Valor das Exportações \\
\hline Setores Primários (Agropecuária) & 19.448 \\
Setor da Soja & 512.140 \\
Setores Secundários (Industriais) & 303.998 \\
Fabricação de óleos vegetais & 416.907 \\
Setores Terciários (Serviços) & 327.040 \\
\hline
\end{tabular}

Fonte: Matriz insumo produto inter-regional Mato Grosso x resto do Brasil, 1999.

A Tabela 32 apresenta os valores da geração total de produção e valor adicionado, em cada setor da economia, ao atender as exportações do estado do Mato Grosso. Como era de se esperar, de acordo com o que foi sugerido pela revisão de literatura, os dois setores mais impactados pelas exportações do Mato Grosso foram Soja (2) e Fabricação de óleos vegetais (33), pertencentes ao próprio estado. O valor da produção gerada no setor Soja (2) foi de $\mathrm{R} \$ 688,54$ milhões e o valor adicionado de $\mathrm{R} \$$ 213,87 milhões. Já no setor Fabricação de óleos vegetais (33) o valor da produção foi de $\mathrm{R} \$ 515,80$ milhões e o valor adicionado de $\mathrm{R} \$ 98,78$ milhões.

Entretanto, outros setores se destacaram também como bastante impactados por estas exportações, a saber: Bovinos (7), Siderurgia (14), Madeira e mobiliário (19), indústria têxtil e calçadista (26), Comércio (39) e Serviços prestados à empresas (48).

No que diz respeito aos setores pertencentes ao resto do Brasil, os mais impactados pelas exportações mato-grossenses foram Adubos e fertilizantes (24), Químicos diversos (21), Comércio (39), Extrativismo mineral (13), Siderurgia (14), Outras culturas (5), e Serviços prestados à empresas (48). O impacto sobre o setor Adubos e fertilizantes (24) pertencente ao resto do Brasil contempla o fato de que o Mato Grosso compra parte dos insumos utilizados na sua produção agrícola, principalmente adubos e fertilizantes, em outros estados brasileiros, uma vez que, conforme mensurado anteriormente, a soja é o principal produto de exportação do estado. 
Tabela 32. Produção (em mil Reais) e valor adicionado (em mil Reais) gerados na economia ao atender as exportações do Mato Grosso.

\begin{tabular}{|c|c|c|c|c|c|}
\hline & \multirow[b]{2}{*}{ Setor } & \multicolumn{2}{|c|}{ Mato Grosso } & \multicolumn{2}{|c|}{ Resto do Brasil } \\
\hline & & Produção & V.A. & Produção & V.A. \\
\hline 1 & Cana-de-açúcar & 10.914 & 4.937 & 5.506 & 3.216 \\
\hline 2 & Soja & 688.541 & 213.876 & 15.275 & 6.409 \\
\hline 3 & Milho & 2.120 & 593 & 12.378 & 4.466 \\
\hline 4 & Fruticultura & 719 & 370 & 4.439 & 2.941 \\
\hline 5 & Outras culturas & 3.932 & 2.112 & 51.344 & 35.574 \\
\hline 6 & Aves & 2.750 & 791 & 3.794 & 1.403 \\
\hline 7 & Bovinos & 71.071 & 27.377 & 11.699 & 5.874 \\
\hline 8 & Suínos & 3.741 & 1.389 & 939 & 449 \\
\hline 9 & Outros pecuária & 13.612 & 5.190 & 22.081 & 10.876 \\
\hline 10 & Extrativismo vegetal & 11.216 & 6.796 & 2.141 & 1.684 \\
\hline 11 & Silvicultura & 114 & 69 & 5.354 & 4.140 \\
\hline 12 & Extrativismo animal (Pesca) & 46 & 27 & 15 & 11 \\
\hline 13 & Extrativismo mineral & 5.443 & 3.167 & 64.441 & 37.481 \\
\hline 14 & Siderurgia & 54.890 & 19.472 & 60.753 & 17.850 \\
\hline 15 & Máquinas e Implementos agrícolas & 291 & 143 & 1.401 & 783 \\
\hline 16 & Outras máquinas e equipamentos & 336 & 169 & 23.566 & 13.549 \\
\hline 17 & Eletro-eletrônicos & 9 & 2 & 4.301 & 1.365 \\
\hline 18 & Peças e veículos & 11 & 3 & 11.795 & 3.226 \\
\hline 19 & Madeira e mobiliário & 100.431 & 41.570 & 4.564 & 1.896 \\
\hline 20 & Celulose, papel e gráfica & 2.351 & 644 & 37.105 & 11.158 \\
\hline 21 & Químicos diversos & 23.799 & 7.323 & 160.693 & 57.645 \\
\hline 22 & Álcool & 13.686 & 4.934 & 12.748 & 5.264 \\
\hline 23 & Refino do Petróleo & 25.428 & 7.673 & 281.515 & 96.974 \\
\hline 24 & Adubos e fertilizantes & 733 & 128 & 193.168 & 38.396 \\
\hline 25 & Farmácia e veterinária & 215 & 83 & 5.532 & 2.447 \\
\hline 26 & Indústria têxtil e calçadista & 27.560 & 11.470 & 23.802 & 6.789 \\
\hline 27 & Indústria do café & 2 & 0 & 440 & 116 \\
\hline 28 & Beneficiamento de produtos vegetais & 1.043 & 248 & 11.556 & 3.143 \\
\hline 29 & Abate de outros animais & 14.988 & 2.481 & 2.119 & 378 \\
\hline 30 & Abate de bovinos & 96.025 & 13.567 & 1.885 & 305 \\
\hline 31 & Indústria de laticínios & 178 & 171 & 547 & 123 \\
\hline 32 & Fabricação de açúcar & 19.735 & 3.725 & 2.352 & 508 \\
\hline 33 & Fabricação de óleos vegetais & 515.802 & 98.768 & 12.724 & 2.805 \\
\hline 34 & Rações & 186 & 50 & 14.407 & 4.385 \\
\hline 35 & Outros produtos alimentares & 3.867 & 982 & 3.711 & 1.059 \\
\hline 36 & Indústrias Diversas & 919 & 309 & 4.169 & 1.602 \\
\hline 37 & S.I.U.P & 34.756 & 14.364 & 31.631 & 17.211 \\
\hline 38 & Construção civil & 4.305 & 2.297 & 3.072 & 1.775 \\
\hline 39 & Comércio & 275.005 & 83.478 & 64.866 & 32.373 \\
\hline 40 & Transporte rodoviário & 66.371 & 25.840 & 14.246 & 5.262 \\
\hline 41 & Transporte aéreo & 23.376 & 7.886 & 6.155 & 1.971 \\
\hline 42 & Transporte ferroviário & 11.767 & 6.042 & 10.366 & 5.053 \\
\hline 43 & Transporte aquaviário & 8.661 & 3.603 & 1.320 & 521 \\
\hline 44 & Atividades auxiliares dos transportes & 21.753 & 10.931 & 5.213 & 2.487 \\
\hline 45 & Comunicações & 25.667 & 21.270 & 14.266 & 11.219 \\
\hline 46 & Instituições financeiras & 35.920 & 24.324 & 20.366 & 13.633 \\
\hline 47 & Serviços prestados às famílias & 55.328 & 32.314 & 5.357 & 2.859 \\
\hline 48 & Serviços prestados às empresas & 98.554 & 69.530 & 25.128 & 16.850 \\
\hline 49 & Aluguel de imóveis & 12.713 & 12.078 & 7.372 & 7.057 \\
\hline 50 & Administração pública & 39.748 & 31.018 & 18.574 & 12.992 \\
\hline 51 & Serviços privados não mercantis & 0 & 0 & 0 & 0 \\
\hline
\end{tabular}

O número de empregos gerados na economia ao atender as exportações do 
Mato Grosso estão apresentados na Tabela 33. O setor que teve o maior número de empregos gerados foi o Comércio (39), tanto no Mato Grosso (7.565 empregos), quanto no resto do Brasil (4.960 empregos). Entretanto, outros setores destacaram-se como importantes geradores de emprego nestas mesmas condições em ambas as regiões, a saber: Soja (2), Bovinos (7), Madeira e mobiliário (19), Químicos diversos (21), Indústria têxtil e calçadista (26), Transporte rodoviário (40), Serviços prestados à famílias (47) e Serviços prestados à empresas (48). Note que dois destes principais geradores de emprego ao atender as exportações mato-grossenses pertencem aos setores primários e dois deles estão diretamente relacionados aos mesmos. 
Tabela 33. Número de empregos gerados na economia ao atender as exportações do Mato Grosso.

\begin{tabular}{|c|c|c|c|}
\hline & & Mato Grosso & Resto do Brasil \\
\hline & Setor & Empregos & Empregos \\
\hline 1 & Cana-de-açúcar & 85 & 524 \\
\hline 2 & Soja & 5609 & 914 \\
\hline 3 & Milho & 443 & 4374 \\
\hline 4 & Fruticultura & 26 & 610 \\
\hline 5 & Outras culturas & 534 & 6974 \\
\hline 6 & Aves & 641 & 884 \\
\hline 7 & Bovinos & 3630 & 741 \\
\hline 8 & Suínos & 548 & 57 \\
\hline 9 & Outros pecuária & 1448 & 1345 \\
\hline 10 & Extrativismo vegetal & 1799 & 343 \\
\hline 11 & Silvicultura & 11 & 536 \\
\hline 12 & Extrativismo animal (Pesca) & 0 & 0 \\
\hline 13 & Extrativismo mineral & 120 & 630 \\
\hline 14 & Siderurgia & 1796 & 760 \\
\hline 15 & Máquinas e Implementos agrícolas & 15 & 18 \\
\hline 16 & Outras máquinas e equipamentos & 74 & 301 \\
\hline 17 & Eletro-eletrônicos & 0 & 33 \\
\hline 18 & Peças e veículos & 0 & 76 \\
\hline 19 & Madeira e mobiliário & 6536 & 224 \\
\hline 20 & Celulose, papel e gráfica & 110 & 520 \\
\hline 21 & Químicos diversos & 2430 & 1420 \\
\hline 22 & Álcool & 45 & 42 \\
\hline 23 & Refino do Petróleo & 66 & 167 \\
\hline 24 & Adubos e fertilizantes & 7 & 677 \\
\hline 25 & Farmácia e veterinária & 37 & 36 \\
\hline 26 & Indústria têxtil e calçadista & 2265 & 1254 \\
\hline 27 & Indústria do café & 0 & 3 \\
\hline 28 & Beneficiamento de produtos vegetais & 71 & 136 \\
\hline 29 & Abate de outros animais & 120 & 19 \\
\hline 30 & Abate de bovinos & 435 & 17 \\
\hline 31 & Indústria de laticínios & 4 & 3 \\
\hline 32 & Fabricação de açúcar & 206 & 22 \\
\hline 33 & Fabricação de óleos vegetais & 311 & 27 \\
\hline 34 & Rações & 15 & 263 \\
\hline 35 & Outros produtos alimentares & 257 & 68 \\
\hline 36 & Indústrias Diversas & 88 & 120 \\
\hline 37 & S.I.U.P & 540 & 125 \\
\hline 38 & Construção civil & 162 & 85 \\
\hline 39 & Comércio & 7656 & 4960 \\
\hline 40 & Transporte rodoviário & 2019 & 762 \\
\hline 41 & Transporte aéreo & 175 & 46 \\
\hline 42 & Transporte ferroviário & 269 & 237 \\
\hline 43 & Transporte aquaviário & 246 & 56 \\
\hline 44 & Atividades auxiliares dos transportes & 1335 & 166 \\
\hline 45 & Comunicações & 102 & 85 \\
\hline 46 & Instituições financeiras & 373 & 175 \\
\hline 47 & Serviços prestados às famílias & 4733 & 539 \\
\hline 48 & Serviços prestados às empresas & 5268 & 1233 \\
\hline 49 & Aluguel de imóveis & 28 & 16 \\
\hline 50 & Administração pública & 1152 & 524 \\
\hline 51 & Serviços privados não mercantis & 0 & 0 \\
\hline
\end{tabular}


A Tabela 34 apresenta o valor da produção e o valor adicionado nos setores pertencentes à duas regiões, ao atender exclusivamente as exportações de soja do Mato Grosso. Dentre os setores mato-grossenses mais impactados por estas exportações em termos de geração de produção total e de valor adicionado estão o próprio setor da Soja (2), o Comércio (39), o Transporte rodoviário (40), Serviços prestados à empresas (48), Instituições financeiras (46), Administração pública (50) e Transporte ferroviário (42). Em relação aos setores pertencentes ao resto do Brasil, os mais impactados em termos das mesmas variáveis foram Adubos e fertilizantes (24), Químicos diversos (21), Refino do petróleo (23), Comércio (39), Extrativismo mineral (13), Administração pública (50), Serviços prestados à empresas (48) e S.I.U.P (37). 
Tabela 34. Produção (em mil Reais) e valor adicionado (em mil Reais) gerados na economia ao atender as exportações de soja do Mato Grosso.

\begin{tabular}{|c|c|c|c|c|c|}
\hline & \multirow[b]{2}{*}{ Setor } & \multicolumn{2}{|c|}{ Mato Grosso } & \multicolumn{2}{|c|}{ Resto do Brasil } \\
\hline & & Produção & V.A. & Produção & V.A. \\
\hline 1 & Cana-de-açúcar & 876 & 396 & 1513 & 884 \\
\hline 2 & Soja & 533077 & 165586 & 1907 & 800 \\
\hline 3 & Milho & 34 & 10 & 6091 & 2197 \\
\hline 4 & Fruticultura & 24 & 13 & 2113 & 1400 \\
\hline 5 & Outras culturas & 172 & 92 & 21662 & 15009 \\
\hline 6 & Aves & 11 & 3 & 352 & 130 \\
\hline 7 & Bovinos & 43 & 17 & 1844 & 926 \\
\hline 8 & Suínos & 9 & 3 & 49 & 23 \\
\hline 9 & Outros pecuária & 599 & 228 & 6655 & 3278 \\
\hline 10 & Extrativismo vegetal & 25 & 15 & 775 & 609 \\
\hline 11 & Silvicultura & 0 & 0 & 304 & 235 \\
\hline 12 & Extrativismo animal (Pesca) & 1 & 1 & 2 & 2 \\
\hline 13 & Extrativismo mineral & 802 & 467 & 24726 & 14381 \\
\hline 14 & Siderurgia & 89 & 32 & 16049 & 4715 \\
\hline 15 & Máquinas e Implementos agrícolas & 24 & 12 & 178 & 100 \\
\hline 16 & Outras máquinas e equipamentos & 7 & 4 & 8596 & 4942 \\
\hline 17 & Eletro-eletrônicos & 0 & 0 & 1113 & 353 \\
\hline 18 & Peças e veículos & 0 & 0 & 2208 & 604 \\
\hline 19 & Madeira e mobiliário & 69 & 29 & 762 & 316 \\
\hline 20 & Celulose, papel e gráfica & 199 & 55 & 7976 & 2399 \\
\hline 21 & Químicos diversos & 40 & 12 & 87684 & 31455 \\
\hline 22 & Álcool & 2386 & 860 & 4077 & 1683 \\
\hline 23 & Refino do Petróleo & 8 & 2 & 116122 & 40001 \\
\hline 24 & Adubos e fertilizantes & 16 & 3 & 140197 & 27867 \\
\hline 25 & Farmácia e veterinária & 2 & 1 & 2185 & 966 \\
\hline 26 & Indústria têxtil e calçadista & 4 & 2 & 4062 & 1159 \\
\hline 27 & Indústria do café & 0 & 0 & 28 & 7 \\
\hline 28 & Beneficiamento de produtos vegetais & 11 & 3 & 766 & 208 \\
\hline 29 & Abate de outros animais & 34 & 6 & 147 & 26 \\
\hline 30 & Abate de bovinos & 31 & 4 & 79 & 13 \\
\hline 31 & Indústria de laticínios & 7 & 7 & 86 & 19 \\
\hline 32 & Fabricação de açúcar & 213 & 40 & 494 & 107 \\
\hline 33 & Fabricação de óleos vegetais & 177 & 34 & 1865 & 411 \\
\hline 34 & Rações & 3 & 1 & 1220 & 371 \\
\hline 35 & Outros produtos alimentares & 68 & 17 & 544 & 155 \\
\hline 36 & Indústrias Diversas & 72 & 24 & 1335 & 513 \\
\hline 37 & S.I.U.P & 3612 & 1493 & 10927 & 5946 \\
\hline 38 & Construção civil & 456 & 243 & 1153 & 666 \\
\hline 39 & Comércio & 56423 & 17127 & 29933 & 14938 \\
\hline 40 & Transporte rodoviário & 10121 & 3940 & 4807 & 1775 \\
\hline 41 & Transporte aéreo & 952 & 321 & 3016 & 966 \\
\hline 42 & Transporte ferroviário & 2948 & 1514 & 4711 & 2296 \\
\hline 43 & Transporte aquaviário & 2681 & 1115 & 637 & 252 \\
\hline 44 & Atividades auxiliares dos transportes & 760 & 382 & 2004 & 956 \\
\hline 45 & Comunicações & 3281 & 2719 & 5365 & 4219 \\
\hline 46 & Instituições financeiras & 5534 & 3747 & 8010 & 5362 \\
\hline 47 & Serviços prestados às famílias & 1311 & 766 & 2032 & 1085 \\
\hline 48 & Serviços prestados às empresas & 8541 & 6025 & 9385 & 6294 \\
\hline 49 & Aluguel de imóveis & 2095 & 1991 & 2587 & 2476 \\
\hline 50 & Administração pública & 3366 & 2627 & 9281 & 6492 \\
\hline 51 & Serviços privados não mercantis & 0 & 0 & 0 & 0 \\
\hline
\end{tabular}


Em relação à geração de novos empregos ao atender as exportações de soja do Mato Grosso, conforme mostram os dados da Tabela 35, os setores mais impactados foram Soja (2), Comércio (39), Serviços prestados à empresas (48) e Transporte rodoviário (40), no próprio estado e Comércio (39), Químicos diversos (21), Adubos e fertilizantes (24), Milho (3) e Outras culturas (5), no resto do Brasil. 
Tabela 35. Número de empregos gerados na economia ao atender as exportações de soja do Mato Grosso.

\begin{tabular}{|c|c|c|c|}
\hline & & Mato Grosso & Resto do Brasil \\
\hline & Setor & Empregos & Empregos \\
\hline 1 & Cana-de-açúcar & 7 & 144 \\
\hline 2 & Soja & 4343 & 114 \\
\hline 3 & Milho & 7 & 2152 \\
\hline 4 & Fruticultura & 1 & 290 \\
\hline 5 & Outras culturas & 23 & 2942 \\
\hline 6 & Aves & 2 & 82 \\
\hline 7 & Bovinos & 2 & 117 \\
\hline 8 & Suínos & 1 & 3 \\
\hline 9 & Outros pecuária & 64 & 405 \\
\hline 10 & Extrativismo vegetal & 4 & 124 \\
\hline 11 & Silvicultura & 0 & 30 \\
\hline 12 & Extrativismo animal (Pesca) & 0 & 0 \\
\hline 13 & Extrativismo mineral & 18 & 242 \\
\hline 14 & Siderurgia & 3 & 201 \\
\hline 15 & Máquinas e Implementos agrícolas & 1 & 2 \\
\hline 16 & Outras máquinas e equipamentos & 2 & 110 \\
\hline 17 & Eletro-eletrônicos & 0 & 9 \\
\hline 18 & Peças e veículos & 0 & 14 \\
\hline 19 & Madeira e mobiliário & 5 & 37 \\
\hline 20 & Celulose, papel e gráfica & 9 & 112 \\
\hline 21 & Químicos diversos & 4 & 775 \\
\hline 22 & Álcool & 8 & 13 \\
\hline 23 & Refino do Petróleo & 0 & 69 \\
\hline 24 & Adubos e fertilizantes & 0 & 491 \\
\hline 25 & Farmácia e veterinária & 0 & 14 \\
\hline 26 & Indústria têxtil e calçadista & 0 & 214 \\
\hline 27 & Indústria do café & 0 & 0 \\
\hline 28 & Beneficiamento de produtos vegetais & 1 & 9 \\
\hline 29 & Abate de outros animais & 0 & 1 \\
\hline 30 & Abate de bovinos & 0 & 1 \\
\hline 31 & Indústria de laticínios & 0 & 1 \\
\hline 32 & Fabricação de açúcar & 2 & 5 \\
\hline 33 & Fabricação de óleos vegetais & 0 & 4 \\
\hline 34 & Rações & 0 & 22 \\
\hline 35 & Outros produtos alimentares & 5 & 10 \\
\hline 36 & Indústrias Diversas & 7 & 39 \\
\hline 37 & S.I.U.P & 56 & 43 \\
\hline 38 & Construção civil & 17 & 32 \\
\hline 39 & Comércio & 1571 & 2289 \\
\hline 40 & Transporte rodoviário & 308 & 257 \\
\hline 41 & Transporte aéreo & 7 & 23 \\
\hline 42 & Transporte ferroviário & 67 & 108 \\
\hline 43 & Transporte aquaviário & 76 & 27 \\
\hline 44 & Atividades auxiliares dos transportes & 47 & 64 \\
\hline 45 & Comunicações & 13 & 32 \\
\hline 46 & Instituições financeiras & 57 & 69 \\
\hline 47 & Serviços prestados às famílias & 112 & 204 \\
\hline 48 & Serviços prestados às empresas & 457 & 461 \\
\hline 49 & Aluguel de imóveis & 5 & 6 \\
\hline 50 & Administração pública & 98 & 262 \\
\hline 51 & Serviços privados não mercantis & 0 & 0 \\
\hline
\end{tabular}

Dados referentes à produção total, quantidade de empregos e valor adicionado, 
gerados na economia mato-grossense ao atender um aumento em $10 \%$ das exportações de soja do Mato Grosso, são apresentados na Tabela 36. Verifica-se, que em termos de produção total gerada na economia, os setores mais impactados foram Soja (2), Comércio (39), Transporte rodoviário (40), Instituições financeiras (46) e Serviços prestados à empresas (48). Já em termos de valor adicionado, os setores mais impactados foram Soja (2), Comércio (39) e Serviços prestados à empresas (48). Os setores que mais tiveram o número de empregos aumentados em decorrência deste aumento das exportações de soja foram o próprio setor Soja (2), com 434 empregos adicionais e o Comércio (39), com 157 empregos adicionais. 
Tabela 36. Impacto sobre a produção (em mil Reais), valor adicionado (em mil Reais) e quantidade de empregos gerados no Mato Grosso, dado um aumento em $10 \%$ das exportações de soja do Mato Grosso.

\begin{tabular}{|c|c|c|c|c|}
\hline & & Produção & Valor Adicionado & Empregos \\
\hline 1 & Cana-de-açúcar & 88 & 40 & 1 \\
\hline 2 & Soja & 53308 & 16559 & 434 \\
\hline 3 & Milho & 3 & 1 & 1 \\
\hline 4 & Fruticultura & 2 & 1 & 0 \\
\hline 5 & Outras culturas & 17 & 9 & 2 \\
\hline 6 & Aves & 1 & 0 & 0 \\
\hline 7 & Bovinos & 4 & 2 & 0 \\
\hline 8 & Suínos & 1 & 0 & 0 \\
\hline 9 & Outros pecuária & 60 & 23 & 6 \\
\hline 10 & Extrativismo vegetal & 3 & 2 & 0 \\
\hline 11 & Silvicultura & 0 & 0 & 0 \\
\hline 12 & Extrativismo animal (Pesca) & 0 & 0 & 0 \\
\hline 13 & Extrativismo mineral & 80 & 47 & 2 \\
\hline 14 & Siderurgia & 9 & 3 & 0 \\
\hline 15 & Máquinas e Implementos agrícolas & 2 & 1 & 0 \\
\hline 16 & Outras máquinas e equipamentos & 1 & 0 & 0 \\
\hline 17 & Eletro-eletrônicos & 0 & 0 & 0 \\
\hline 18 & Peças e veículos & 0 & 0 & 0 \\
\hline 19 & Madeira e mobiliário & 7 & 3 & 0 \\
\hline 20 & Celulose, papel e gráfica & 20 & 5 & 1 \\
\hline 21 & Químicos diversos & 4 & 1 & 0 \\
\hline 22 & Álcool & 239 & 86 & 1 \\
\hline 23 & Refino do Petróleo & 1 & 0 & 0 \\
\hline 24 & Adubos e fertilizantes & 2 & 0 & 0 \\
\hline 25 & Farmácia e veterinária & 0 & 0 & 0 \\
\hline 26 & Indústria têxtil e calçadista & 0 & 0 & 0 \\
\hline 27 & Indústria do café & 0 & 0 & 0 \\
\hline 28 & Beneficiamento de produtos vegetais & 1 & 0 & 0 \\
\hline 29 & Abate de outros animais & 3 & 1 & 0 \\
\hline 30 & Abate de bovinos & 3 & 0 & 0 \\
\hline 31 & Indústria de laticínios & 1 & 1 & 0 \\
\hline 32 & Fabricação de açúcar & 21 & 4 & 0 \\
\hline 33 & Fabricação de óleos vegetais & 18 & 3 & 0 \\
\hline 34 & Rações & 0 & 0 & 0 \\
\hline 35 & Outros produtos alimentares & 7 & 2 & 0 \\
\hline 36 & Indústrias Diversas & 7 & 2 & 1 \\
\hline 37 & S.I.U.P & 361 & 149 & 6 \\
\hline 38 & Construção civil & 46 & 24 & 2 \\
\hline 39 & Comércio & 5642 & 1713 & 157 \\
\hline 40 & Transporte rodoviário & 1012 & 394 & 31 \\
\hline 41 & Transporte aéreo & 95 & 32 & 1 \\
\hline 42 & Transporte ferroviário & 295 & 151 & 7 \\
\hline 43 & Transporte aquaviário & 268 & 112 & 8 \\
\hline 44 & Atividades auxiliares dos transportes & 76 & 38 & 5 \\
\hline 45 & Comunicações & 328 & 272 & 1 \\
\hline 46 & Instituições financeiras & 553 & 375 & 6 \\
\hline 47 & Serviços prestados às famílias & 131 & 77 & 11 \\
\hline 48 & Serviços prestados às empresas & 854 & 603 & 46 \\
\hline 49 & Aluguel de imóveis & 210 & 199 & 0 \\
\hline 50 & Administração pública & 337 & 263 & 10 \\
\hline 51 & Serviços privados não mercantis & 0 & 0 & 0 \\
\hline
\end{tabular}


Dados referentes à produção total, quantidade de empregos e valor adicionado, gerados na economia do resto do Brasil ao atender um acréscimo de $10 \%$ nas exportações de soja do Mato Grosso, são apresentados na Tabela 37. Em termos de produção total gerada, os setores mais impactados foram Adubos e fertilizantes (24), Outras Máquinas e equipamentos (16), Químicos diversos (21), Extrativismo mineral (13), Milho (3), Outras culturas (5), Outros pecuária (9), Siderurgia (14), Celulose, papel e gráfica (20), Refino do petróleo (23), S.I.U.P. (37), Comércio (39), Comunicações (45), Instituições financeiras (46), Serviços prestados æ̀̀ empresas (48) e Administração pública (50). Em relação ao valor adicionado, destacaram-se os setores Outras culturas (5), Extrativismo mineral (13), Químicos diversos (21), Refino do petróleo (23), Adubos e fertilizantes (24), S.I.U.P. (37), Comércio (39), Comunicações (45), Instituições financeiras (46), Serviços prestados à empresas (48) e Administração pública (50). Os setores que mais tiveram o número de empregos aumentados foram Milho (3), com 215 empregos adicionais, Outras culturas (5), com 294 empregos adicionais, Químicos diversos (21), com 77 empregos adicionais e Comércio (39), com 229 empregos adicionais. 
Tabela 37. Impacto sobre a produção (em mil Reais), valor adicionado (em mil Reais) e quantidade de empregos gerados no Resto do Brasil, dado um aumento em $10 \%$ das exportações de soja do Mato Grosso.

\begin{tabular}{|c|c|c|c|c|}
\hline & & Produção & Valor Adicionado & Empregos \\
\hline 1 & Cana-de-açúcar & 151 & 88 & 14 \\
\hline 2 & Soja & 191 & 80 & 11 \\
\hline 3 & Milho & 609 & 220 & 215 \\
\hline 4 & Fruticultura & 211 & 140 & 29 \\
\hline 5 & Outras culturas & 2166 & 1501 & 294 \\
\hline 6 & Aves & 35 & 13 & 8 \\
\hline 7 & Bovinos & 184 & 93 & 12 \\
\hline 8 & Suínos & 5 & 2 & 0 \\
\hline 9 & Outros pecuária & 666 & 328 & 41 \\
\hline 10 & Extrativismo vegetal & 77 & 61 & 12 \\
\hline 11 & Silvicultura & 30 & 24 & 3 \\
\hline 12 & Extrativismo animal (Pesca) & 0 & 0 & 0 \\
\hline 13 & Extrativismo mineral & 2473 & 1438 & 24 \\
\hline 14 & Siderurgia & 1605 & 472 & 20 \\
\hline 15 & Máquinas e Implementos agrícolas & 18 & 10 & 0 \\
\hline 16 & Outras máquinas e equipamentos & 860 & 494 & 11 \\
\hline 17 & Eletro-eletrônicos & 111 & 35 & 1 \\
\hline 18 & Peças e veículos & 221 & 60 & 1 \\
\hline 19 & Madeira e mobiliário & 76 & 32 & 4 \\
\hline 20 & Celulose, papel e gráfica & 798 & 240 & 11 \\
\hline 21 & Químicos diversos & 8768 & 3145 & 77 \\
\hline 22 & Álcool & 408 & 168 & 1 \\
\hline 23 & Refino do Petróleo & 11612 & 4000 & 7 \\
\hline 24 & Adubos e fertilizantes & 14020 & 2787 & 49 \\
\hline 25 & Farmácia e veterinária & 219 & 97 & 1 \\
\hline 26 & Indústria têxtil e calçadista & 406 & 116 & 21 \\
\hline 27 & Indústria do café & 3 & 1 & 0 \\
\hline 28 & Beneficiamento de produtos vegetais & 77 & 21 & 1 \\
\hline 29 & Abate de outros animais & 15 & 3 & 0 \\
\hline 30 & Abate de bovinos & 8 & 1 & 0 \\
\hline 31 & Indústria de laticínios & 9 & 2 & 0 \\
\hline 32 & Fabricação de açúcar & 49 & 11 & 0 \\
\hline 33 & Fabricação de óleos vegetais & 186 & 41 & 0 \\
\hline 34 & Rações & 122 & 37 & 2 \\
\hline 35 & Outros produtos alimentares & 54 & 16 & 1 \\
\hline 36 & Indústrias Diversas & 134 & 51 & 4 \\
\hline 37 & S.I.U.P & 1093 & 595 & 4 \\
\hline 38 & Construção civil & 115 & 67 & 3 \\
\hline 39 & Comércio & 2993 & 1494 & 229 \\
\hline 40 & Transporte rodoviário & 481 & 178 & 26 \\
\hline 41 & Transporte aéreo & 302 & 97 & 2 \\
\hline 42 & Transporte ferroviário & 471 & 230 & 11 \\
\hline 43 & Transporte aquaviário & 64 & 25 & 3 \\
\hline 44 & Atividades auxiliares dos transportes & 200 & 96 & 6 \\
\hline 45 & Comunicações & 537 & 422 & 3 \\
\hline 46 & Instituições financeiras & 801 & 536 & 7 \\
\hline 47 & Serviços prestados às famílias & 203 & 108 & 20 \\
\hline 48 & Serviços prestados às empresas & 939 & 629 & 46 \\
\hline 49 & Aluguel de imóveis & 259 & 248 & 1 \\
\hline 50 & Administração pública & 928 & 649 & 26 \\
\hline 51 & Serviços privados não mercantis & 0 & 0 & 0 \\
\hline
\end{tabular}


Outro aspecto importante da cultura da soja no Mato Grosso é a participação de seu Sistema Agroindustrial no Produto Interno Bruto (PIB) do estado. Desta forma, calculou-se o PIB, tanto do agronegócio da soja no Mato Grosso, quanto o total do estado, para verificar qual a participação do agronegócio da soja na renda do estado. Como resultado, o valor do PIB do agronegócio da soja no Mato Grosso em 1999 foi de R \$ 1.071,756 milhões, participando em torno de 10\% na formação do PIB do estado, que por sua vez foi de $\mathrm{R} \$ 11.537,28$ milhões.

\subsection{Impacto sobre a produção dos setores de transporte rodoviário e ferroviário}

Objetivando verificar qual o impacto gerado na produção dos setores Transporte rodoviário (40) e Transporte ferroviário (42), em ambas as regiões, ao atender um aumento em um milhão de Reais na demanda final de cada um dos setores pertencentes ao Mato Grosso, foi dado um choque na demanda final de cada um dos 51 setores do Mato Grosso e isolado o impacto causado por cada uma destas demandas sobre a produção das duas atividades, tanto no Mato Grosso quanto no resto do Brasil. Os resultados obtidos são apresentados na Tabela 38. Os setores responsáveis pelos maiores impactos na produção do Transporte rodoviário (40) do Mato Grosso são o próprio Transporte rodoviário (40), Transporte aquaviário (43), Transporte aéreo (41), Fabricação de açúcar (32) e Atividades auxiliares dos transportes (44). Já no caso do impacto sobre a produção do Transporte ferroviário (42) no Mato Grosso, destacam-se como principais o próprio Transporte ferroviário (42), Refino do Petróleo (23), Adubos e Fertilizantes (24), Transporte aquaviário (43), Químicos Diversos (21), Transporte aéreo (41), Farmácia e veterinária (25), Milho (3), Atividades auxiliares dos transportes (44) e Soja (2).

Os setores mato-grossenses cujas demandas causam os maiores impactos na produção do Transporte rodoviário (40) no resto do Brasil são Abate de Bovinos (30), Abate de outros animais (29), Bovinos (7), Fabricação de óleos vegetais (33), Suínos (8), Outros da pecuária (9), Soja (2), Aves (6), Milho (3) e Álcool (22), e no Transporte ferroviário (42) são Milho (3), Transporte rodoviário (40), Soja (2), Transporte aéreo 
(41), Comércio (39), Transporte aquaviário (43), Cana-de-açúcar (1), Adubos e Fertilizantes (24), Extrativismo animal (12) e Fabricação de óleos vegetais (33).

Vale destacar que, com excessão do Refino do Petróleo (23), Químicos diversos (21) e os próprios setores relacionados æ̀ atividades de transportes, a maioria das atividades mato-grossenses classificadas entre as que mais demandam os meios de transporte de ambas as regiões, pertencem à atividades primárias ou estão diretamente relacionadas àestas. 
Tabela 38. Impacto da demanda final de um milhão de Reais de cada setor do Mato Grosso sobre a produção (em mil Reais) dos setores de transporte na economia.

\begin{tabular}{|c|c|c|c|c|c|}
\hline & & \multicolumn{2}{|c|}{ Mato Grosso } & \multicolumn{2}{|c|}{ Resto do Brasil } \\
\hline & & Rodoviário & Ferroviário & Rodoviário & Ferroviário \\
\hline 1 & Cana-de-açúcar & 22 & 4 & 7 & 7 \\
\hline 2 & Soja & 20 & 6 & 9 & 9 \\
\hline 3 & Milho & 21 & 7 & 9 & 10 \\
\hline 4 & Fruticultura & 26 & 1 & 5 & 4 \\
\hline 5 & Outras culturas & 24 & 2 & 8 & 4 \\
\hline 6 & Aves & 27 & 5 & 9 & 6 \\
\hline 7 & Bovinos & 19 & 2 & 12 & 5 \\
\hline 8 & Suínos & 23 & 3 & 12 & 6 \\
\hline 9 & Outros pecuária & 22 & 3 & 10 & 5 \\
\hline 10 & Extrativismo vegetal & 27 & 2 & 8 & 3 \\
\hline 11 & Silvicultura & 35 & 5 & 2 & 2 \\
\hline 12 & Extrativismo animal (Pesca) & 31 & 4 & 3 & 6 \\
\hline 13 & Extrativismo mineral & 5 & 2 & 4 & 4 \\
\hline 14 & Siderurgia & 31 & 4 & 4 & 4 \\
\hline 15 & Máquinas e Implementos agrícolas & 13 & 2 & 6 & 3 \\
\hline 16 & Outras máquinas e equipamentos & 17 & 4 & 2 & 2 \\
\hline 17 & Eletro-eletrônicos & 28 & 6 & 3 & 3 \\
\hline 18 & Peças e veículos & 21 & 4 & 3 & 3 \\
\hline 19 & Madeira e mobiliário & 27 & 2 & 8 & 4 \\
\hline 20 & Celulose, papel e gráfica & 17 & 4 & 4 & 3 \\
\hline 21 & Químicos diversos & 20 & 12 & 4 & 4 \\
\hline 22 & Álcool & 26 & 2 & 8 & 4 \\
\hline 23 & Refino do Petróleo & 6 & 37 & 5 & 3 \\
\hline 24 & Adubos e fertilizantes & 7 & 13 & 5 & 6 \\
\hline 25 & Farmácia e veterinária & 30 & 7 & 4 & 3 \\
\hline 26 & Indústria têxtil e calçadista & 21 & 2 & 5 & 4 \\
\hline 27 & Indústria do café & 24 & 2 & 6 & 3 \\
\hline 28 & Beneficiamento de produtos vegetais & 30 & 2 & 6 & 4 \\
\hline 29 & Abate de outros animais & 37 & 2 & 13 & 5 \\
\hline 30 & Abate de bovinos & 36 & 2 & 13 & 5 \\
\hline 31 & Indústria de laticínios & 1 & 0 & 0 & 0 \\
\hline 32 & Fabricação de açúcar & 40 & 2 & 7 & 5 \\
\hline 33 & Fabricação de óleos vegetais & 35 & 3 & 12 & 6 \\
\hline 34 & Rações & 25 & 6 & 6 & 4 \\
\hline 35 & Outros produtos alimentares & 29 & 5 & 7 & 5 \\
\hline 36 & Indústrias Diversas & 16 & 4 & 5 & 4 \\
\hline 37 & S.I.U.P & 3 & 1 & 2 & 2 \\
\hline 38 & Construção civil & 15 & 1 & 6 & 3 \\
\hline 39 & Comércio & 30 & 3 & 8 & 9 \\
\hline 40 & Transporte rodoviário & 62 & 6 & 4 & 10 \\
\hline 41 & Transporte aéreo & 45 & 11 & 4 & 9 \\
\hline 42 & Transporte ferroviário & 34 & 51 & 4 & 4 \\
\hline 43 & Transporte aquaviário & 61 & 12 & 4 & 8 \\
\hline 44 & Atividades auxiliares dos transportes & 37 & 6 & 4 & 5 \\
\hline 45 & Comunicações & 4 & 0 & 1 & 1 \\
\hline 46 & Instituições financeiras & 7 & 0 & 1 & 1 \\
\hline 47 & Serviços prestados às famílias & 9 & 1 & 5 & 2 \\
\hline 48 & Serviços prestados às empresas & 4 & 0 & 2 & 1 \\
\hline 49 & Aluguel de imóveis & 1 & 0 & 0 & 0 \\
\hline 50 & Administração pública & 5 & 1 & 2 & 1 \\
\hline 51 & Serviços privados não mercantis & 2 & 0 & 1 & 0 \\
\hline
\end{tabular}




\section{CONCLUSÕES}

Este trabalho, no contexto atual da economia brasileira, objetivou avaliar a importância relativa da agricultura na estrututura produtiva do Mato Grosso, um estado que, de acordo com a revisão de literatura, vem apresentando considerável desempenho na atividade agropecuária desde a década de 70, o que contribuiu para que a sua economia crescesse a um ritmo superior à média do país ao longo das últimas décadas. A hipótese básica testada foi a de que o setor agrícola constitui o eixo dinâmico da economia do estado, ou seja, a indústria surge ao redor da acumulação de capital no setor primário.

Da teoria econômica sabe-se que, à medida que uma economia se desenvolve, usualmente uma porção cada vez menor do PIB provém da agricultura, e um contingente cada vez menor da força de trabalho depende diretamente das atividades primárias, o que não implica em redução da importância do setor, e sim conduz à mudança de ênfase quanto aos papéis da agricultura no desenvolvimento econômico. Os resultados empíricos confirmaram a importância dos setores primários em termos de suas relações comerciais com as demais atividades, como forma de estimular o aquecimento da economia, bem como a importância dos produtos agrícolas no mercado internacional, como forma de atrair ganhos cambiais ao país, além de impactar positivamente a produção de diversos outros setores na economia.

A mensuração dos índices puros de ligações permitiu identificar dezessete setores-chave na estrutura produtiva do estado, sendo três deles atividades primárias e quatro deles diretamente relacionados a estas, o que vem a confirmar a importância das atividades agrícolas no que diz respeito às relações de compra e venda de insumos, 
constituindo-se mercado consumidor para os setores não-agrícolas, além de fornecedor de matéria-prima para a indústria.

Em especial merece destaque a cultura da soja, a qual além de ter se destacado como importante compradora e fornecedora de insumos, apresentado elevado efeito multiplicador da renda, produção e emprego na economia, também se destacou em termos da importância de suas exportações. Resultado interessante do presente estudo é que o número de empregos diretos gerados para cada milhão de demanda final atendidos pela produção de soja do MT é de fato, modesto. Entretanto, quando se considera os efeitos indiretos e induzidos na multiplicação de empregos, nota-se que o setor da soja é bastante dinâmico, induzindo-nos a concluir que, para se avaliar a relevância de um determinado setor na geração de empregos é preciso analisar não somente a sua capacidade de geração direta de emprego, mas a sua relação na estrutura produtiva da economia, como forma de multiplicar o emprego nas atividades fornecedoras de seus insumos. O mesmo acontece com a renda, inclusive, em termos de efeito multiplicador da renda, o setor da soja no Mato Grosso ocupou a primeira posição no ranking, quando comparado com os demais setores. No que diz respeito à exportações de soja do estado, estas apresentaram-se importantes tanto em termos de geração de divisas, por representarem em torno de $\mathrm{R} \$ 512$ milhões, quanto em termos de estímulo à produção de outros setores, como Adubos e fertilizantes (24), Transporte ferroviário (42), Transporte rodoviário (40), Comércio (39), dentre outros, além dos empregos gerados em decorrência do seu efeito multiplicador.

Uma regularidade empírica observada no presente estudo é que há uma relação inversa entre as magnitudes do multiplicador e gerador de emprego, respectivamente, ou seja, quanto maior o multiplicador, menor o gerador, sugerindo a existência uma relação entre intensidade de capital no setor (e, em decorrência, da produtividade do trabalho) e os multiplicadores e geradores de emprego. Os setores com elevada intensidade de capital geram poucos empregos diretos, mas multiplicam muito este emprego, demandando produção de setores intensivos em trabalho (produtividade do trabalho mais baixa). 
O mesmo fenômeno ocorre no que se refere à multiplicação e ge ração de renda (entenda-se salário). Quanto mais intensivo em capital for um determinado setor, menor a participação da renda do trabalho no seu produto e, desta maneira, para cada milhão de produto gerado há geração de parcela diminuta da renda do trabalho, podendo-se notar entretanto, que como a produtividade do trabalho é alta nesta atividade hipotética, a cada emprego gerado no mesmo há ampla multiplicação da renda pelos setores fornecedores de insumos menos intensivos em capital e, portanto, multiplicadores de renda.

Dentro das relações inter-setoriais é notória a relevância do setor de transportes, em decorrência tanto do abastecimento do estado do Mato Grosso com insumos produzidos pelo resto do Brasil, quanto da exportação da produção do estado para o restante do país, sugerindo que o segmento de transportes é peça central no desenvolvimento regional. Desta forma, o presente trabalho procurou avaliar qual o impacto gerado na produção dos principais setores de transporte, rodoviário e ferroviário, em ambas as regiões, ao atender a demanda final em um milhão de Reais, de cada um dos setores pertencentes ao Mato Grosso, e obteve como resultado, que estes segmentos são fortemente impactados quando atendidas as demandas finais das atividades agropecuárias, ou então, de setores diretamente relacionados à estas. Entretanto, dada a importância do segmento de transportes ao desenvolvimento regional, fica como uma sugestão a realização de algumas atualizações e refinamentos da metodologia utilizada, para que se possa desenvolver um instrumental de avaliação de políticas de estímulo ao desenvolvimento da infra-estrutura de transportes da região.

Os resultados do trabalho dão conta da forte relação entre as economias do Mato Grosso e do restante do país, e no que se refere ao setor primário, os resultados sugerem que há forte dependência de insumos importados das demais regiões brasileiras. Ademais, parte considerável da produção agropecuária é exportada do Estado, tornandose claro, portanto, que investimentos em infra-estrutura são de vital importância para a manutenção do crescimento econômico do Mato Grosso. Além disso, os efeitos das diferentes estruturas tributárias em cada estado do país dificultam sobremaneira as relações inter-regionais, gerando custos adicionais ao sistema produtivo, de modo que as políticas públicas destinadas ao investimento em infra-estrutura de transportes e 
abastecimento, bem como daquelas voltadas à harmonização do sistema tributário, contribuiriam para a manutenção das elevadas taxas de crescimento observadas no Estado do Mato Grosso nos últimos anos. 


\section{REFERÊNCIAS BIBLIOGRÁFICAS}

\section{ASSOCIAÇÃO BRASILEIRA DAS INDÚSTRIAS DE ÓLEOS VEGETAIS.}

Esmagamento mensal de soja. http://www.abiove.com.br (20 fev. 2003)

ALVES, A.F. Contribuição da agricultura ao crescimento econômico: o excedente financeiro de 1980 a 1998. Piracicaba, 2000. 127p. Tese (Doutorado) - Escola Superior de Agricultura “Luiz de Queiroz”, Universidade de São Paulo.

ARAÚJO, P.F.C.; ALMEIDA, A. Financiamento da agricultura no Brasil: da crise do crédito barato à perspectiva de um novo modelo. In: SEMINÁRIO INTERNACIONAL DE POLÍTICA AGRÍCOLA, 8., Viçosa, 1996. Anais. Viçosa: UFV, 1996. p.161-81.

ARAÚJO, P.F.C.; SCHUH, G.E. Desenvolvimento econômico e agricultura. In: BARROS, G.S.C. Fundamentos de economia agrícola. Piracicaba: ESALQ, Depto. Economia, Administração e Sociologia Rural, 1991. cap.4, p.227-259.

BARROS, J.R.; GRAHAM, D.H. A agricultura brasileira e o problema na produção de alimentos. Pesquisa e Planejamento Econômico, v.8, n.3, p.695-726, 1978.

BARROS, A.L.M. Capital, produtividade e crescimento da agricultura: o Brasil de 1970 a 1995. Piracicaba, 1999. 220p. Tese (Doutorado) - Escola Superior de Agricultura "Luiz de Queiroz", Universidade de São Paulo. 
BARROS, G.S.A.C.; ARAÚJO, P.F.C. Oferta e demanda de crédito rural no Brasil: algumas evidências empíricas sobre seus determinantes. Piracicaba: CEPEA/FEALQ, 1991. 32p.

BRASIL. Ministério do Desenvolvimento, Indústria e Comércio Exterior. Comércio exterior: indicadores e estatísticas: commodities. http://www.mdic.gov.br. (07 mar. 2003)

BULMER-THOMAS, V. Input-output analysis in developing countries. New York: John Wiley and Sons, 1982. 297p.

CAIXETA FILHO, J.V.; SILVA, N.D.V.; GAMEIRO, A.H. et al. Competitividade no agribusiness: a questão do transporte em um contexto logístico (compact disc). In: COMPETITIVIDADE NO AGRIBUSINESS BRASILEIRO, São Paulo, 1998. Trabalhos. São Paulo: PENSA/FIA/FEA/USP, 1998. v.5: v.3.

CELLA, G. The input-output measurement of interindustry linkages. Oxford Bulletin of Economic and Statistics, v.46, p.73-84, 1984.

CENTRO DE ESTUDOS AVANÇADOS EM ECONOMIA APLICADA (CEPEA). PIB do agronegócio. http://cepea.esalq.usp.br (20 abr. 2003)

CHENERY, H.; CLARK, P.G. Interindustry economics. New York: John Wiley and Sons, 1959. 345p.

CLEMENTS, B.J. On the decomposition and normalization of interindustry linkages. Economics Letters, v.33, n.4, p.337-340, Aug. 1990.

CONFEDERAÇÃO NACIONAL DA AGRICULTURA E PECUÁRIA. Renda agropecuária. http://www.cna.org.br (20 abr. 2003) 
COELHO, C.N. A agricultura e a logística de transportes. http://www.mre.gov.br/ cdbrasil/itamaraty/web/port/economia/agric/logist/apresent.htm (14 ago. 2003)

COMPANHIA NACIONAL DO ABASTECIMENTO. Indicadores agropecuários. http://www.conab.gov.br. (27 fev. 2003)

CONSIDERA, C.M.; RAMOS, R.L.O.; MAGALHÃES, K.M.M.; FILGUEIRAS, H.V.; SOBRAL, C.B. Matrizes de insumo-produto regionais 1985 e 1992: metodologia e resultados. Rio de Janeiro: Instituto de Pesquisa Econômica Aplicada, 1997. http://www.nemesis.org.br (10 maio 2003)

COSTA, R.C.; TOSTA, E.J. Armazenagem: diagnósticos e perspectivas. Revista de Política Agrícola, v.4, n.3, p.18-27, jul./ago./set. 1995.

CROCOMO, F.C. Análise das relações inter-regionais e intersetoriais na economia brasileira em 1985: uma aplicação de insumo-produto. Piracicaba, 1998. 179p. Tese (Doutorado) - Escola Superior de Agricultura "Luiz de Queiroz", Universidade de São Paulo.

DAVIS, H.C. Multiregional input-output techniques and western water resources development. Berkeley: University of California, 1968. 142p.

DE ZEN, S. Diversificação como forma de gerenciamento de risco na agricultura. Piracicaba, 2002. 107p. Tese (Doutorado) - Escola Superior de Agricultura "Luiz de Queiroz", Universidade de São Paulo.

DINIZ, C.C. Desenvolvimento poligonal no Brasil: nem desconcentração, nem contínua polarização. Nova Economia, v.3, n.1, p.35-64, set. 1993. 
DIPASQUALE, D.; POLENSKE, K.R. In: Impact analysis: methodology and applications. New York: S. Pleeter, 1980. p.85-113: Output, income and employment input-output multipliers.

EMPRESA BRASILEIRA DE PESQUISA AGROPECUÁRIA. Tecnologias de produção de soja na região central do Brasil. Londrina: Embrapa Soja, 2002. 199p.

FAO. Statistical databases: Faostat: agriculture. http://www.fao.org. (01 Mar. 2003)

FEIJÓ, C.A.; RAMOS, R.L.O.; YOUNG, C.E.F. et al. Contabilidade social: o novo sistema de contas nacionais do Brasil. Rio de Janeiro: Campus, 2001. 356p.

FERNANDES, C.L.L. A inserção de Minas na economia nacional: uma análise de insumo-produto inter-regional. Rio de Janeiro, 1997. 209p. Tese (Doutorado) Universidade Federal do Rio de Janeiro.

FERREIRA, V. Estradas ruins oneram custo da safra no Mato Grosso. O Estado de São Paulo, São Paulo, 02 mar. 2003. p.G-6.

FERREIRA FILHO, J.B.S. Ajustamento estrutural e crescimento agrícola na década de oitenta: notas adicionais. Piracicaba: ESALQ, Depto. Economia e Sociologia Rural, 1997. 280p. (Série estudo, 52)

FURTUOSO, M.C.O.; BARROS, G.S.C.; GUILHOTO, J.J.M. O Produto Interno Bruto do complexo agroindustrial brasileiro. Revista de Economia e Sociologia Rural, v.36, n.3, p.9-31, jul./set. 1998.

GALINDO, O.; SANTOS, V.M. Centro-Oeste: evolução recente da economia regional. São Paulo: UNESP/FUNDAP, 1995. 240p. 
GEILING, K. Como andam os modais. Brasil Transportes, v.32, n.345, p.16-19, mar. 1996.

GOLDIN, I.; REZENDE, G.C. A agricultura brasileira na década de 80: crescimentos numa economia em crise. Rio de Janeiro: IPEA, 1993. 246p.

GOMES, G.M.; VERGOLINO, J.R. Trinta e cinco anos de crescimento na Amazônia, 1960/1995. Brasília: IPEA, 1997. 146p. (Texto para Discussão, 533)

GUILHOTO, J.J.M.; FURTUOSO, M.C.O.; BARROS, G.S.C. O agronegócio na economia brasileira (1994-1999). Piracicaba: CNA/CEPEA/ESALQ, 2000. 112p.

GUILHOTO, J.J.M.; SESSO FILHO, U.A.; LOPES, R.L.; HILGEMBERG, C.M.A.T.; HILGEMBERG, E.M. Nota metodológica: construção da matriz insumo-produto utilizando dados preliminares das contas nacionais (compact disc). In: ENCONTRO BRASILEIRO DE ESTUDOS REGIONAIS E URBANOS, 2., São Paulo, 2002. Anais. Belo Horizonte: Associação Brasileira de Estudos Regionais, 2002.

GUILHOTO, J.J.M.; SONIS, M.; HEWINGS, G.J.D.; MARTINS, E.B. Índices de ligações e setores-chave na economia brasileira: 1959/80. Pesquisa e Planejamento Econômico, v.2, n.24, p.287-314, ago. 1994.

GUILHOTO, J.J.M.; SONIS, M.; HEWINGS, G.J.D. Linkages and multipliers in a multiregional framework: integrations of alternative approaches. Illinois: REAL, 1996. 19p. (Discussion Paper, 8)

GUIMARÃES NETO, L. Desigualdades e políticas regionais no Brasil: caminhos e descaminhos. Planejamento e Políticas Públicas, v.2, n.15, p.77-130, jun. 1997. 
HAYAMI, Y.; RUTTAN, V.W. Agricultural development: an international perspective. Baltimore: Johns Hopkins, 1971. 367p.

HELFAND, S.M.; REZENDE, G. C. Padrões regionais de crescimento da produção de grãos no Brasil e o papel da região Centro-Oeste. Rio de Janeiro: IPEA, 2000. 25p. (Texto para Discussão, 731)

HIRSCHMAN, A. The strategy of economic development. New Haven: Yale University Press, 1958. 217p.

INSTITUTO BRASILEIRO DE GEOGRAFIA E ESTATÍSTICA. Censo agropecuário 1995-1996: Brasil. Rio de Janeiro, 1998. 358p.

INSTITUTO BRASILEIRO DE GEOGRAFIA E ESTATÍSTICA. Censo agropecuário 1995-1996: Mato Grosso. Rio de Janeiro, 1998. 224p.

INSTITUTO BRASILEIRO DE GEOGRAFIA E ESTATÍSTICA. Contas nacionais: Brasil: 1999-2001. http://www.ibge.gov.br (02 out. 2003)

INSTITUTO BRASILEIRO DE GEOGRAFIA E ESTATÍSTICA. Produção agrícola municipal. Rio de Janeiro, 1970-2002.

ISARD, W.; KUENNE, R.E. The impact of steel upon the greater New York: Philadelphia Industrial Region. Review of Economics and Statistics, v.35, n.4, p.289-301, Nov. 1953.

JENSEN, R.C. Some accounting procedures and their effects on input-output multipliers. Annals of Regional Sciense, v.12, n.3, p.21-38, Nov. 1978. 
JENSEN, R.C.; WEST, G. The effect of relative coefficient size on input-output multipliers. Environment and Planning, v.12, n.6, p.659-70, June 1980.

JOHNSTON, B.F.; MELLOR, J.W. The role of agriculture in economic development. American Economic Review, v.51, n.4, p.566-593, Set. 1961.

KUZNETS, S. Economic growth and the contribution of agriculture: notes on measurements. In: EICHER, C.K.; WITT, L.W. Agriculture in economic development. New York: McGraw-Hill, 1964. cap.5, p.102-120.

LAZZARINI, S.G.; NUNES, R. Competitividade do sistema agroindustrial da soja (compact disc). In: COMPETITIVIDADE NO AGRIBUSINESS BRASILEIRO, São Paulo, 1998. Trabalhos. São Paulo: PENSA/FIA/FEA/USP, 1998. v.6, pt.A.

LEONTIEF, W. The structure of american economy, 1919-1939. New York: Oxford University Press, 1966. 264p.

LEWIS, W.A. Economic development with unlimited supplies of labor. The Manchester School of Economics and Social Studies, v.22, p.139-92, May 1954.

LÍCIO, A.; CORBUCCI, R. Agricultura e os corredores de transporte multimodais. Revista de Política Agrícola, v.4, n.4, p.3-4, out./nov./dez. 1995.

LITTLE, I.M.D. Economic development: theory, policy and international relations. New York: Basic Books, 1982. 452p.

MARQUES, R.W.C.; CAIXETA FILHO, J.V. Ferronorte e transporte de grãos. Preços Agrícolas, v.1, n.140, p.12-17, jun. 1998. 
MARTIN, M.A. Modernization of brazilian agriculture: an analysis of unbalanced development. Purdue, 1976. 500p. Thesis (PhD) - Purdue University.

MATO GROSSO. Secretaria de Agricultura e Assuntos Fundiários. Programa MatoGrossense de Melhoramento da Pecuária (PROMMEPE). Manual do PROMMEPE. Mato Grosso, 2001. 53p.

MCGILVRAY, J. Linkages, key sectors and development strategy. In: LEONTIEF, W. Structure, system and economic policy. Cambridge: University Press, 1977. p.4956.

MIERNYK, W.H. The elements of input-output analysis. New York: Random House, 1965. 156p.

MILLER, R.E. The impact of the aluminum industry on the Pacifc Northwest: a regional input-output analysis. Review of Economics and Statistics, v.39, n.2, p.200-209, May 1957.

MILLER, R.E.; BLAIR, P.D. Input-ouput analysis: foundations and extensions. New Jersey: Englewood Cliffs, 1985. 464p.

MIYAZAWA, K. Input-output analysis and the structure of income distribution. Berlin: Springer-Verlag, 1976. 135p.

MONTEIRO NETO, A.; GOMES, G. M. Quatro décadas de crescimento econômico no centro-oeste brasileiro. Brasília: IPEA, 2000. 29p. (Texto para Discussão, 712)

MORAES, M. Relações contratuais entre sojicultores e indústria no Mato Grosso. Piracicaba: ESALQ, Depto. Economia, Administração e Sociologia, 2001. 370p. (Série didática, 41) 
MORETTO, A.C. Relações intersetoriais e inter-regionais na economia paranaense em 1995. Piracicaba, 2000. 160p. Tese (Doutorado) - Escola Superior de Agricultura "Luiz de Queiroz", Universidade de São Paulo

MORGENSTERN, O. Economic activity analysis. New York: John Wiley and Sons, 1954. 544p.

MOURA, J.G.; CÂMARA, S.F.; LIMA, R.C. Eficiência alocativa e crescimento econômico: o papel do setor agrícola (compact disc). In: CONGRESSO BRASILEIRO DE ECONOMIA E SOCIOLOGIA RURAL, 41., Foz do Iguaçu, 1999. Anais. Brasília: SOBER, 1999.

NICHOLLS, W.H. The place of agriculture in economic development. In: EICHER, C.; WITT, L. (Ed.). Agriculture in economic development. New York: McGraw-Hill, 1964. cap.1, p.11-44.

OWEN, W.F. A dupla pressão do processo de desenvolvimento sobre a agricultura. In: ARAÚJO, P.F.C.; SCHUH, G.E. (Coord.). Desenvolvimento da agricultura: natureza do processo e modelos dualistas. São Paulo: Pioneira, 1975. p.39-65.

PADILHA, J.B. Estratégias de comercialização de soja frente ao risco de mercado. Piracicaba, 1997. 117p. Dissertação (Mestrado) - Escola Superior de Agricultura “Luiz de Queiroz”, Universidade de São Paulo.

PEREIRA, S.R. A política de garantia de preços mínimos e o complexo soja. Revista de Política Agrícola, v.2, n.3, p.23-24, jul./set. 1993. 
PIRES, F. Os avanços do transporte ferroviário de carga no Brasil após as privatizações: uma análise segundo a perspectiva de usuários, prestadores de serviço e governo. http://www.coppeadufrj.br/pesquisa/cel/new/fs-busca.htm?fr-avanço.htm (12 ago. 2003)

POLENSKE, K.R. Frontiers of input-output analysis. New York: Oxford University Press, 1989. 335p.

PORTAL BRASIL. Geografia geral: região Centro-Oeste: Mato Grosso. http://www.portalbrasil.eti.br/estados_mt.htm (10 abr. 2003)

RANIS, G.; FEI, J.C.H. A theory of economic development. American Economic Review, v.51, n.4, p.533-65, Sep. 1961.

RASMUSSEN, P. Studies in intersectoral relations. Amsterdam: North Holland, 1956. 210p.

REZENDE, G.C.; BUAINAIN, A.M. Structural adjustment and agriculture in Brazil: the experience of the 1980's. Revista Brasileira de Economia, v.48, n.4, p.491503, out./dez. 1994.

RICHETTI, A. Fronteira de produção e eficiência econômica na cultura da soja no Mato Grosso do Sul. Lavras, 2000. 82p. Dissertação (Mestrado) - Universidade Federal de Lavras.

RICHARDSON, H.W. Input-output and regional economics. New York: John Wiley and Sons, 1972. 294p.

SANDRONI, P. Dicionário de economia. São Paulo: Best Seller, 1989. 331p. 
SANTOS, A.B. Evolução diferenciada entre os estados brasileiros do cultivo e do processamento industrial da soja - período de 1970 a 1999. Piracicaba, 2000. 98p. Dissertação (Mestrado) - Escola Superior de Agricultura "Luiz de Queiroz", Universidade de São Paulo.

SARTORI, A. Entrevista com diretor analista da Corretora Brasoja. http://www.cib.org.br/lista-entrevista.php. (15 fev. 2003)

SCHAFFER, W.A. On the use of input-output models for regional planning. Leiden: Martinus Nijhoff, 1976. 170p.

SCHUH, G.E. Política agrícola numa economia internacional bem integrada: o caso do Brasil. Revista de Economia e Sociologia Rural, v.27, n.2, p.107-24, abr./jun. 1989.

SCHUH, G.E. A agricultura no Brasil: política, modernização e desenvolvimento econômico. Revista de Política Agrícola, v.4, n.2, p.15-21, abr./maio/jun. 1997.

SCHULTZ, T.W. A transformação da agricultura tradicional. Rio de Janeiro: Zahar, 1965. 207p.

SILVA, A.C.S. Mato Grosso permanece grande e forte: a economia mato-grossense após a divisão. Goiânia: Única, 1982. 210p.

SILVA, G.L.S.P. Reflexões sobre o papel da agricultura no Brasil. Agricultura em São Paulo, v.29, n.1-2, p.1-120, 1982.

SONIS, M.; HEWINGS, G.J.D. Error and sensitivity input-output analysis: a new approach. In: MILLER, R.E.; POLENSKE, K. R.; ROSE, A.Z. (Ed.). Frontiers of input-output analysis. New York: Oxford University Press, 1989. p.232-244. 
STONE, R. Input-output and national accounts. Paris: Organization for European Economic Cooperation, 1961. 202p.

STUANI, R. Caminhos da soja se expandem do sudeste à Amazônia. Estado de São Paulo. São Paulo, 22 set. 2002a. p.G-4.

STUANI, R. Ferrovias e hidrovias diminuem os gargalos da safra. Estado de São Paulo. São Paulo, 18 out. 2002b. p.G-3.

TOSTO, S.G. Mercado interno de grãos de soja: modelos de equilíbrio e desequilíbrio

Piracicaba, 1996. 114p. Dissertação (Mestrado) - Escola Superior de Agricultura "Luiz de Queiroz", Universidade de São Paulo.

WEINGÄRTNER,A.S. Divisionismo: história de Mato Grosso do Sul. http://www.ccerqueira.hpg.ig.com.br (02 abr. 2003)

WEST, G.; JENSEN, R.C. Some reflections on input-output multipliers. Annals of Regional Sciense, v.14, n.2, p.77-89, July 1980.

YAMADA, I. Theory and application of interindustry analysis. Tokyo: Konokuniya Book-Store Co., 1961. 254p.

YAN, C.S. Introduction to input-output economics. New York: Holt, 1969. 134p.

YOTOPOULOS, P.A.; NUGENT, J.B. Economics of development: empirical investigations. New York: Harper \& Row Publishers, 1976. 478p. 
APÊNDICES 
APÊNDICE 1 - Matriz insumo-produto inter-regional Mato Grosso x resto do Brasil / 1999.

\begin{tabular}{|c|c|c|c|c|c|c|c|c|c|c|c|c|c|c|}
\hline \multirow{2}{*}{\multicolumn{2}{|c|}{$\begin{array}{l}\text { Mato Grosso } \\
\text { Setores }\end{array}$}} & \multicolumn{13}{|c|}{ Mato Grosso } \\
\hline & & 1 & 2 & 3 & 4 & 5 & 6 & & 8 & 9 & 10 & 11 & 12 & 13 \\
\hline 1 & Cana-de-açúcar & 4763 & 0 & 0 & 0 & 1 & 0 & 238 & 0 & 7786 & 0 & 0 & 2 & 0 \\
\hline 2 & Soja & 0 & 61619 & 0 & 26 & 383 & 0 & 0 & 0 & 2443 & 0 & 0 & 0 & 0 \\
\hline 3 & Milho & 70 & 0 & 7076 & 776 & 10079 & 5577 & 7249 & 18861 & 25361 & 91 & 1 & 0 & 0 \\
\hline 4 & Fruticultura & 0 & 0 & 216 & 1318 & 12033 & 0 & 0 & 1000 & 5235 & 0 & 0 & 0 & 0 \\
\hline 5 & Outras culturas & 1230 & 96 & 855 & 2544 & 14406 & 247 & 730 & 0 & 25825 & 221 & 66 & 124 & 38 \\
\hline 6 & Aves & 11 & 0 & 29 & 77 & 502 & 15716 & 63 & 0 & 1070 & 8 & 0 & 0 & 0 \\
\hline 7 & Bovinos & 0 & 0 & 267 & 118 & 898 & 109 & 81330 & 0 & 15589 & 46 & 1 & 0 & 0 \\
\hline 8 & Súnos & 0 & 0 & 0 & 0 & 0 & 0 & 0 & 747 & 0 & 0 & 0 & 0 & 0 \\
\hline 9 & Outros pecuária & 0 & 1607 & 1442 & 1126 & 14302 & 0 & 4837 & 0 & 33202 & 0 & 0 & 0 & 0 \\
\hline 10 & Extrativismo vegetal & 1 & 2 & 1 & 1 & 16 & 1 & 10 & 0 & 5 & 50 & 1 & 0 & 2 \\
\hline 11 & Silvicultura & 0 & 0 & 0 & 0 & 0 & 0 & 0 & 0 & 0 & 0 & 0 & 0 & 0 \\
\hline 12 & Extrativismo animal & 0 & 0 & 0 & 0 & 0 & 0 & 0 & 0 & 0 & 0 & 0 & 0 & 0 \\
\hline 13 & Extrat. Mineral & 758 & 1380 & 478 & 467 & 6128 & 158 & 6298 & 7 & 2847 & 6 & 3 & 91 & 1242 \\
\hline 14 & Siderurgia & 17 & 37 & 12 & 17 & 140 & 12 & 139 & 1 & 64 & 0 & 2 & 2 & 45 \\
\hline 15 & Maq. e implem. agrícolas & 4 & 13 & 1 & 2 & 25 & 37 & 18 & 2 & 12 & 1 & 0 & 1 & 45 \\
\hline 16 & Outras maq. e equip. & 1 & 4 & 0 & 1 & 7 & 11 & 5 & 0 & 4 & 0 & 0 & 0 & 13 \\
\hline 17 & Eletro-eletrônicos & 0 & 0 & 0 & 0 & 0 & 0 & 0 & 0 & 0 & 0 & 0 & 0 & 0 \\
\hline 18 & Peças e veículos & 0 & 0 & 0 & 0 & 0 & 0 & 0 & 0 & 0 & 0 & 0 & 0 & 0 \\
\hline 19 & Madeira e mobiliário & 31 & 37 & 29 & 124 & 1781 & 134 & 113 & 38 & 275 & 47 & 0 & 34 & 193 \\
\hline 20 & cel., papel e gráfica & 0 & 0 & 0 & 2 & 0 & 4 & 0 & 0 & 0 & 0 & 0 & 2 & 0 \\
\hline 21 & Químicos diversos & 1 & 5 & 0 & 3 & 2 & 4 & 7 & 1 & 1 & 0 & 7 & 0 & 1 \\
\hline 22 & Âlcool & 4 & 22 & 2 & 2 & 23 & 24 & 18 & 1 & 11 & 1 & 1 & 0 & 31 \\
\hline 23 & Refino do petróleo & -12 & -159 & -15 & -2 & -36 & 5 & -25 & -2 & -20 & -2 & 19 & 3 & 5 \\
\hline 24 & $\begin{array}{l}\text { Renno oo perroleo } \\
\text { Adubos e fertilizantes }\end{array}$ & $\begin{array}{c}-12 \\
0\end{array}$ & $\begin{array}{c}-199 \\
4\end{array}$ & $\begin{array}{c}-13 \\
0\end{array}$ & $\begin{array}{c}-2 \\
266\end{array}$ & $\begin{array}{c}-36 \\
1\end{array}$ & 22 & $\begin{array}{c}-29 \\
1\end{array}$ & $\begin{array}{l}-2 \\
0\end{array}$ & $\begin{array}{c}-20 \\
1\end{array}$ & 0 & $\begin{array}{c}19 \\
9\end{array}$ & 0 & 0 \\
\hline 25 & $\begin{array}{l}\text { Auuosose lerturzantes } \\
\text { Farmac e veterinária }\end{array}$ & 0 & 1 & 0 & $\begin{array}{c}200 \\
0\end{array}$ & 1 & 3 & 1 & $\begin{array}{l}0 \\
0\end{array}$ & 1 & 0 & 0 & 0 & 3 \\
\hline 26 & Ind. têxtil e calçadista & 0 & 1 & 0 & 0 & 1 & 1 & 2 & 0 & 0 & 0 & 0 & 0 & 2 \\
\hline 27 & $\begin{array}{l}\text { Indústria do café } \\
\text { (a)a }\end{array}$ & 0 & 0 & 0 & 0 & 0 & 0 & 0 & 0 & 0 & 0 & 0 & 0 & 0 \\
\hline 28 & Benef. Prod. vegetais & 2 & 8 & 2 & 3 & 26 & 27 & 30 & 6 & 24 & 0 & 0 & 0 & 1 \\
\hline 29 & Abate de outros animais & 1 & $\begin{array}{l}\circ \\
13\end{array}$ & 4 & 3 & 40 & 1 & 17 & 0 & 87 & 0 & 0 & 0 & 4 \\
\hline 30 & Abate de bovinos & 1 & 19 & 9 & 7 & 88 & 1 & 33 & 0 & 199 & 0 & 0 & 0 & $\begin{array}{l}4 \\
5\end{array}$ \\
\hline 31 & Indústria de laticínios & 1 & 7 & 1 & 0 & 2 & 0 & 2 & 0 & 1 & 0 & 0 & 0 & 1 \\
\hline 32 & Fabricação de açúcar & 23 & 48 & 4 & 9 & 108 & 117 & 59 & 5 & 70 & 4 & 0 & 44 & 145 \\
\hline 33 & Fab. óleos vegetais & 152 & 172 & 52 & 66 & 879 & 7621 & 27272 & 2385 & 14 & 58 & 1 & 1 & 15 \\
\hline 34 & Rações & 0 & 2 & 5 & 39 & 3 & 3594 & 1 & 630 & 5 & 0 & 1 & 0 & 1 \\
\hline 35 & Outros prod. alimentares & 2 & 7 & 2 & 4 & 31 & 12 & 16 & 2 & 25 & 0 & 0 & 0 & 3 \\
\hline 36 & Indústrias diversas & 0 & 1 & 0 & 0 & 0 & 0 & 0 & 0 & 0 & 0 & 0 & 180 & 1 \\
\hline 37 & S.I.U.P. & 689 & 2077 & 167 & 299 & 4000 & 6068 & 2860 & 267 & 1910 & 205 & 1 & 1 & 7609 \\
\hline 38 & Construção civil & 7 & 58 & 5 & 4 & 56 & 4 & 57 & 4 & 26 & 6 & 0 & 1 & 649 \\
\hline 39 & Comércio & 14321 & 155007 & 15074 & 5094 & 50059 & 5742 & 39385 & 2829 & 27751 & 2787 & 17 & 1759 & 8940 \\
\hline 40 & Transporte rodoviário & 2867 & 22923 & 1836 & 2031 & 23350 & 1869 & 24122 & 1513 & 10840 & 2467 & 14 & 579 & 598 \\
\hline 41 & Transporte aéreo & 18 & 146 & 12 & 11 & 149 & 11 & 158 & 10 & 70 & 16 & 0 & 3 & 5460 \\
\hline 42 & Transporte ferroviário & 534 & 7581 & 735 & 0 & 2142 & 391 & 2147 & 164 & 1175 & 189 & 1 & 65 & 483 \\
\hline 43 & Transporte aquaviário & 358 & 7032 & 457 & 292 & 2059 & 197 & 2049 & 120 & 1250 & 234 & 1 & 40 & 1 \\
\hline $\begin{array}{l}43 \\
44\end{array}$ & Atividades aux. dos transp. & $\begin{array}{c}508 \\
0\end{array}$ & $\begin{array}{c}1032 \\
4\end{array}$ & $\begin{array}{c}45 / 1 \\
0\end{array}$ & 0 & 5 & 3 & 76 & 1 & 10 & $\begin{array}{c}234 \\
0\end{array}$ & 0 & $\begin{array}{c}40 \\
0\end{array}$ & $\begin{array}{c}1 \\
1163\end{array}$ \\
\hline $\begin{array}{l}44 \\
45\end{array}$ & $\begin{array}{l}\text { Auvidadaes aux. uos transp. } \\
\text { Comunicaçōes }\end{array}$ & 102 & $\begin{array}{c}4 \\
813\end{array}$ & $\begin{array}{l}0 \\
65\end{array}$ & $\begin{array}{l}0 \\
63\end{array}$ & $\begin{array}{c}5 \\
828\end{array}$ & $\begin{array}{c}3 \\
58\end{array}$ & $\begin{array}{l}10 \\
854\end{array}$ & $\begin{array}{l}1 \\
54\end{array}$ & $\begin{array}{l}10 \\
384\end{array}$ & 87 & 0 & 58 & 1994 \\
\hline 46 & Instituiç̄oses financeiras & 1110 & 8875 & 711 & 689 & 9040 & 634 & 9330 & 586 & 4196 & 955 & 5 & 197 & 6408 \\
\hline 47 & Serv. prest. às famílias & 19 & 305 & 24 & 26 & 334 & 137 & 3961 & 32 & 565 & 33 & 0 & 2 & 660 \\
\hline 48 & Serv. prest. às empresas & 1460 & 11684 & 936 & 906 & 11879 & 834 & 12257 & 770 & 5514 & 1255 & 7 & 258 & 5923 \\
\hline 49 & Aluguel de imóveis & 1 & 28 & 2 & 3 & 37 & $\begin{array}{l}804 \\
20\end{array}$ & 600 & 10 & 72 & 4 & 0 & $\begin{array}{c}200 \\
0\end{array}$ & 1014 \\
\hline 50 & & 534 & 4238 & 361 & 432 & 4620 & 316 & 4505 & 279 & 2560 & $\begin{array}{c}4 \\
455\end{array}$ & 7 & 136 & 2159 \\
\hline 51 & Serv. priv. ño mercantis & 0 & 0 & 0 & 0 & 0 & $\begin{array}{c}510 \\
0\end{array}$ & 0 & 0 & 0 & 0 & 0 & $\begin{array}{c}150 \\
0\end{array}$ & 0 \\
\hline
\end{tabular}


APÊNDICE 1 - Matriz insumo-produto inter-regional Mato Grosso x resto do Brasil / 1999.

\begin{tabular}{|c|c|c|c|c|c|c|c|c|c|c|c|c|c|c|}
\hline \multirow{2}{*}{\multicolumn{2}{|c|}{$\begin{array}{l}\text { Mato Grosso } \\
\text { Setores }\end{array}$}} & \multicolumn{13}{|c|}{ Mato Grosso } \\
\hline & & 14 & 15 & 16 & 17 & 18 & 19 & 20 & 21 & 22 & 23 & 24 & 25 & 26 \\
\hline 1 & Cana-de-açúcar & 0 & 0 & 0 & 0 & 0 & 0 & 0 & 2 & 78448 & 0 & 0 & 1 & 0 \\
\hline 2 & Soja & 1 & 0 & 0 & 0 & 0 & 0 & 36 & 20 & 1 & 1 & 12 & 5 & 0 \\
\hline 3 & Milho & 0 & 0 & 0 & 0 & 0 & 0 & 0 & 0 & 0 & 0 & 0 & 0 & 0 \\
\hline 4 & Fruticultura & 0 & 0 & 0 & 0 & 0 & 0 & 2 & 1 & 0 & 0 & 1 & 0 & 0 \\
\hline 5 & Outras culturas & 0 & 0 & 0 & 0 & 0 & 0 & 4 & 345 & 0 & 0 & 1 & 4 & 30 \\
\hline 6 & Aves & 0 & 0 & 0 & 0 & 0 & 0 & 0 & 0 & 0 & 0 & 0 & 0 & 0 \\
\hline 7 & Bovinos & 0 & 0 & 0 & 0 & 0 & 0 & 0 & 5 & 0 & 0 & 0 & 7 & 0 \\
\hline 8 & Suínos & 0 & 0 & 0 & 0 & 0 & 0 & 0 & 1 & 0 & 0 & 0 & 1 & 112 \\
\hline 9 & Outros pecuária & 0 & 0 & 0 & 0 & 0 & 0 & 0 & 132 & 0 & 0 & 0 & 14 & 101 \\
\hline 10 & Extrativismo vegetal & 1032 & 0 & 0 & 0 & 0 & 35918 & 0 & 655 & 0 & 0 & 0 & 0 & 1 \\
\hline 11 & Silvicultura & 97 & 0 & 0 & 0 & 0 & 106 & 0 & 0 & 0 & 0 & 0 & 0 & 0 \\
\hline 12 & Extrativismo animal & 0 & 0 & 0 & 0 & 0 & 0 & 0 & 0 & 0 & 0 & 0 & 0 & 0 \\
\hline 13 & Extrat. Mineral & 6117 & 5 & 2 & 1 & 1 & 253 & 126 & 653 & 250 & 115 & 197 & 41 & 52 \\
\hline 14 & $\begin{array}{l}\text { Siderurgia } \\
\end{array}$ & 52960 & 349 & 367 & 70 & 202 & 482 & 105 & 1115 & 19 & 588 & 146 & 240 & 38 \\
\hline 15 & Maq. e implem. agrícolas & 76 & 2 & 4 & 2 & 2 & 53 & 12 & 10 & 58 & 11 & 1 & 1 & 4 \\
\hline 16 & Outras maq. e equip. & 21 & 0 & 28 & 7 & 16 & 16 & 12 & 3 & 17 & 3 & 0 & 0 & 3 \\
\hline 17 & Eletro-eletrônicos & 0 & 0 & 6 & 8 & 1 & 0 & 0 & 0 & 0 & 0 & 0 & 0 & 0 \\
\hline 18 & Peças e veículos & 1 & 0 & 3 & 0 & 12 & 0 & 0 & 0 & 0 & 0 & 0 & 0 & 0 \\
\hline 19 & Madeira e mobiliário & 1265 & 21 & 25 & 12 & 20 & 45992 & 35 & 117 & 9 & 25 & 7 & 33 & 175 \\
\hline 20 & cel., papel e gráfica & 188 & 3 & 2 & 1 & 1 & 9 & 1513 & 54 & 0 & 24 & 10 & 35 & 29 \\
\hline 21 & Químicos diversos & 1084 & 40 & 30 & 5 & 14 & 341 & 696 & 7648 & 1 & 1596 & 592 & 623 & 383 \\
\hline 22 & Âlcool & 142 & 3 & 2 & 1 & $\begin{array}{c}14 \\
1\end{array}$ & $\begin{array}{c}541 \\
81\end{array}$ & 46 & 1141 & 1555 & 3915 & 231 & 153 & 21 \\
\hline 23 & Refino do petróleo & 1230 & 20 & 21 & 8 & 15 & 213 & 337 & 5400 & 11 & 17729 & 707 & 383 & 140 \\
\hline 24 & $\begin{array}{l}\text { Kerno doo pertoleo } \\
\text { Adubos e fertilizantes }\end{array}$ & $\begin{array}{c}1230 \\
20\end{array}$ & 0 & $\begin{array}{c}21 \\
0\end{array}$ & $\begin{array}{l}8 \\
0\end{array}$ & 0 & 2 & $\begin{array}{c}331 \\
3\end{array}$ & $\begin{array}{c}5400 \\
66\end{array}$ & 0 & 122 & 6925 & $\begin{array}{c}383 \\
14\end{array}$ & $\begin{array}{c}140 \\
1\end{array}$ \\
\hline 25 & $\begin{array}{l}\text { Aduobose } \mathrm{e} \text { Iertuizzantes } \\
\text { Farmac e veterinária }\end{array}$ & $\begin{array}{c}20 \\
6\end{array}$ & 0 & 0 & 0 & 0 & 4 & 4 & $\begin{array}{l}60 \\
68\end{array}$ & 3 & 12 & $\begin{array}{c}9025 \\
6\end{array}$ & $\begin{array}{l}14 \\
233\end{array}$ & 1 \\
\hline 26 & Ind. têxtil e calçadista & 11 & 3 & 4 & 1 & 3 & 32 & 8 & 92 & 2 & 13 & 10 & 8 & 5493 \\
\hline 27 & $\begin{array}{l}\text { Indústria do café } \\
\text { a ta }\end{array}$ & 0 & 0 & 0 & 0 & 0 & 0 & 0 & 0 & 0 & 0 & 0 & 0 & 0 \\
\hline 28 & Benef. Prod. vegetais & 3 & 0 & 0 & 0 & 0 & 3 & 30 & 29 & 1 & 6 & 12 & 14 & 1 \\
\hline 29 & Abate de outros animais & 5 & 0 & 0 & 0 & 0 & 7 & 1 & 14 & 1 & 1 & 0 & 14 & 2105 \\
\hline 30 & Abate de bovinos & 5 & 0 & 0 & 0 & 0 & 7 & 2 & $\begin{array}{l}14 \\
4\end{array}$ & 1 & 1 & 1 & 10 & 44 \\
\hline 31 & Indústria de laticínios & 1 & 0 & 0 & 0 & 0 & 2 & 1 & 7 & 0 & 0 & 0 & 6 & 0 \\
\hline 32 & Fabricação de açúcar & 143 & 2 & 1 & 0 & 0 & 166 & 27 & 45 & 8626 & 27 & 3 & 14 & 11 \\
\hline 33 & Fab. óleos vegetais & 67 & 1 & 1 & 0 & 0 & 41 & 44 & 1082 & 4 & 200 & 66 & 896 & 42 \\
\hline 34 & Rações & 1 & 0 & 0 & 0 & 0 & 1 & 1 & 5 & 0 & 2 & 1 & 4 & 9 \\
\hline 35 & Outros prod. alimentares & & 2 & 1 & 0 & 0 & 13 & 14 & 40 & 5 & 14 & 11 & $\begin{array}{c}4 \\
13\end{array}$ & 20 \\
\hline 36 & Indústrias diversas & 231 & 2 & 7 & 5 & 4 & 7 & 151 & 80 & 3 & 33 & 20 & 10 & 28 \\
\hline 37 & S.I.U.P. & 7721 & 117 & 36 & 4 & 13 & 7617 & 1366 & 1031 & 9143 & 1439 & 139 & 80 & 562 \\
\hline 38 & Construção civil & 420 & 19 & 6 & 1 & 2 & 620 & 119 & 91 & 500 & 145 & 28 & 21 & 62 \\
\hline 39 & Comércio & 8737 & 324 & 95 & 21 & 59 & 27307 & 3042 & 2620 & 4602 & 2542 & 933 & 863 & 2823 \\
\hline 40 & Transporte rodoviário & 4245 & 53 & 14 & 4 & 6 & 6495 & 404 & 522 & 3794 & 63 & 24 & 203 & 529 \\
\hline 41 & Transporte aéreo & 1143 & 5 & 3 & 0 & 1 & 109 & 64 & 120 & 12 & 3 & 347 & 5 & 4 \\
\hline $\begin{array}{l}41 \\
42\end{array}$ & Transporte ferroviário & 513 & 7 & 4 & 1 & 1 & 283 & 115 & 246 & 12 & 2498 & 167 & 40 & 28 \\
\hline 43 & Transporte aquaviário & 0 & 0 & 0 & 0 & 0 & 1 & 1 & 0 & 0 & 0 & 0 & 0 & 0 \\
\hline 44 & Atividades aux. dos transp. & 1035 & 19 & 4 & 1 & 1 & 1186 & 101 & 153 & 663 & 439 & 92 & 43 & 97 \\
\hline 45 & Comunicações & 2482 & 140 & 41 & 6 & 9 & 4423 & 944 & 500 & 1120 & 563 & 210 & 163 & 438 \\
\hline 46 & Instituiçōes financeiras & 2534 & 52 & 15 & 6 & 11 & 1579 & 552 & 741 & 2779 & 1135 & 331 & 6 & 178 \\
\hline 47 & Serv. prest. às famílias & 431 & 21 & 9 & 1 & 3 & 806 & 102 & 127 & 234 & 91 & 30 & 26 & 184 \\
\hline 48 & Serv. prest. às empresas & 1457 & 67 & 20 & 5 & 7 & 2352 & 669 & 334 & 916 & 463 & 115 & 374 & 424 \\
\hline 49 & Aluguel de imóveis & 553 & 22 & 6 & 1 & 1 & 1340 & 232 & 93 & 139 & 86 & 40 & 36 & 122 \\
\hline 50 & Administracã̃o pública & 1705 & 52 & 38 & 12 & 84 & 1157 & 7611 & 634 & 337 & 790 & 1963 & 815 & 493 \\
\hline 51 & Serv. priv. não mercantis & 0 & 0 & $\begin{array}{c}50 \\
0\end{array}$ & 0 & $\begin{array}{c}84 \\
0\end{array}$ & 0 & 0 & 0 & 0 & 0 & 0 & 0 & 0 \\
\hline
\end{tabular}


APÊNDICE 1 - Matriz insumo-produto inter-regional Mato Grosso x resto do Brasil / 1999.

\begin{tabular}{|c|c|c|c|c|c|c|c|c|c|c|c|c|c|c|}
\hline \multirow{2}{*}{\multicolumn{2}{|c|}{$\begin{array}{l}\text { Mato Grosso } \\
\text { Setores }\end{array}$}} & \multicolumn{13}{|c|}{ Mato Grosso } \\
\hline & & 27 & 28 & 29 & 30 & 31 & 32 & 33 & 34 & 35 & 36 & 37 & 38 & 39 \\
\hline 1 & Cana-de-açúcar & 0 & 22 & 0 & 0 & 0 & 35845 & 0 & 43 & & & & & \\
\hline 2 & Soja & 0 & 960 & 47 & 8 & 3 & 0 & 324863 & 437 & 2651 & 0 & 0 & 0 & 0 \\
\hline 3 & Milho & 0 & 1659 & 70 & 0 & 0 & 0 & 130 & 2744 & 4294 & 0 & 0 & 0 & 0 \\
\hline 4 & Fruticultura & 0 & 4491 & 2 & 0 & 1 & 0 & 0 & 23 & 5439 & 0 & 0 & 0 & 0 \\
\hline 5 & Outras culturas & 4323 & 31566 & 1089 & 211 & 0 & 79 & 363 & 88 & 2582 & 0 & 0 & 0 & 0 \\
\hline 6 & Aves & 0 & 0 & 50303 & 0 & 0 & 0 & 0 & 0 & 489 & 0 & 0 & 0 & 0 \\
\hline 7 & Bovinos & 0 & 62 & 0 & 198950 & 741 & 0 & 323 & 79 & 460 & 2 & 0 & 0 & 0 \\
\hline 8 & Súnos & 0 & 0 & 85845 & 0 & 0 & 0 & 16 & 0 & 19 & 0 & 0 & 0 & 0 \\
\hline 9 & Outros pecuária & 0 & 0 & 580 & 0 & 1 & 0 & 21034 & 2434 & 2252 & 98 & 217 & 0 & 0 \\
\hline 10 & Extrativismo vegetal & 0 & 20 & 1 & 1 & 0 & 0 & 0 & 1 & 2 & 3 & 0 & 124 & 0 \\
\hline 11 & Silvicultura & 0 & 0 & 0 & 0 & 0 & 0 & 0 & 0 & 0 & 0 & 0 & 1 & 0 \\
\hline 12 & Extrativismo animal & 0 & 0 & 0 & 0 & 0 & 0 & 0 & 0 & 0 & 0 & 0 & 0 & 0 \\
\hline 13 & Extrat. Mineral & 3 & 60 & 224 & 248 & 1 & 114 & 522 & 303 & 635 & 1187 & 4682 & 6748 & 5970 \\
\hline 14 & $\begin{array}{l}\text { Siderurgia } \\
\end{array}$ & 25 & 695 & 16 & 11 & 3 & 94 & 29 & 44 & 2273 & 633 & 362 & 66375 & 571 \\
\hline 15 & Maq. e implem. agrícolas & 0 & 8 & 26 & 18 & 0 & 24 & 64 & 5 & 19 & 4 & 1046 & 18 & 720 \\
\hline 16 & Outras maq. e equip. & 0 & 2 & 8 & 5 & 0 & 7 & 19 & 1 & 6 & 1 & 312 & 5 & 215 \\
\hline 17 & Eletro-eletrônicos & 0 & 0 & 0 & 0 & 0 & 0 & 0 & 0 & 0 & 0 & 1 & 0 & 1 \\
\hline 18 & Peças e veículos & 0 & 0 & 0 & 0 & 0 & 0 & 0 & 0 & 0 & 0 & 2 & 0 & 1 \\
\hline 19 & Madeira e mobiliário & 3 & 33 & 302 & 220 & 0 & 4 & 14 & 57 & 228 & 314 & 75 & 31313 & 694 \\
\hline 20 & cel., papel e gráfica & 4 & 101 & 11 & 0 & 1 & 1 & 0 & 21 & 545 & 87 & 140 & 81 & 39 \\
\hline 21 & Químicos diversos & 3 & 65 & 1 & 1 & 0 & 1 & 39 & 76 & 102 & 307 & 69 & 7 & 67 \\
\hline 22 & Âlcool & 2 & 24 & 19 & 13 & 0 & 203 & 45 & 90 & 337 & 30 & 827 & 99 & 184897 \\
\hline 23 & Refino do petróleo & 47 & 216 & -18 & -14 & 1 & -1 & -45 & 69 & 84 & 400 & 283 & -22 & 184 \\
\hline 24 & Adubos e fertilizantes & 0 & 1 & 0 & 0 & 0 & 0 & 1 & 0 & 1 & 4 & 1 & 4 & 33 \\
\hline 25 & Farmac. e veterinária & 0 & 2 & 2 & 1 & 0 & 1 & 4 & 10 & 14 & 2 & 56 & 1 & 67 \\
\hline 26 & Ind. têxtil e calçadista & 6 & 5 & 1 & 102 & 0 & 1 & 11 & 5 & 19 & 59 & 29 & 4 & 98 \\
\hline 27 & $\begin{array}{l}\text { Indústria do café } \\
\text { a ta }\end{array}$ & 820 & 1 & 0 & 0 & 0 & 0 & 0 & 1 & 2 & 0 & 0 & 0 & 17 \\
\hline 28 & Benef. Prod. vegetais & 9 & 1588 & 45 & 8 & 6 & 1 & 81 & 3369 & 9538 & 1 & 4 & 2 & 158 \\
\hline 29 & Abate de outros animais & 0 & 8 & 17225 & 3 & 0 & 1 & $\begin{array}{l}01 \\
361\end{array}$ & 8 & 676 & 9 & 16 & 7 & $\begin{array}{l}100 \\
647\end{array}$ \\
\hline 30 & Abate de bovinos & 0 & 23 & 4 & 34762 & 0 & 1 & 2055 & 17 & 497 & 16 & 17 & 7 & $\begin{array}{l}041 \\
662\end{array}$ \\
\hline 31 & Indústria de laticínios & 0 & 42 & 6 & 23 & 312 & 0 & 4 & 136 & 483 & 0 & 3 & 1 & 136 \\
\hline 32 & Fabricação de açúcar & 1 & 441 & 84 & 59 & 8 & 21204 & 204 & 842 & 3726 & 6 & 3308 & 48 & 3065 \\
\hline 33 & Fab. óleos vegetais & 1 & 497 & 132 & 94 & 9 & 5 & 209046 & 65 & 11735 & 19 & 53 & 21 & 2091 \\
\hline 34 & Raçōes & 0 & 1 & 117 & 0 & 0 & 0 & 4 & 1466 & 1 & 0 & 2 & 1 & 88 \\
\hline 35 & Outros prod. alimentares & 6 & 129 & 6 & 4 & 4 & 8 & 54 & 12 & 8202 & 32 & 10 & 4 & 948 \\
\hline 36 & Indústrias diversas & 4 & 18 & 8 & 0 & 1 & 12 & 1 & 13 & 46 & 179 & 313 & 1003 & 89 \\
\hline 37 & S.I.U.P. & 37 & 1053 & 4128 & 2892 & 20 & 3946 & 10035 & 749 & 3138 & 317 & 166374 & 2645 & 101563 \\
\hline 38 & Construção civil & 6 & 95 & 600 & 440 & 3 & 769 & 816 & 56 & 234 & 51 & 2546 & 69255 & 11614 \\
\hline 39 & Comércio & 254 & 7383 & 23457 & 17172 & 84 & 7775 & 58126 & 3245 & 13586 & 1971 & 6925 & 57966 & 154419 \\
\hline 40 & Transporte rodoviário & 66 & 1376 & 7697 & 7052 & $\begin{array}{l}2+ \\
29\end{array}$ & 3417 & 21862 & 462 & 2657 & 274 & 440 & 15725 & 110481 \\
\hline 41 & Transporte aéreo & 2 & 65 & 19 & 40 & 1 & 138 & 1692 & 101 & 39 & 94 & 99 & 707 & 35084 \\
\hline $\begin{array}{l}41 \\
42\end{array}$ & Transporte ferroviário & 1 & 34 & 72 & $\begin{array}{l}40 \\
49\end{array}$ & $\begin{array}{l}1 \\
2\end{array}$ & 24 & $\begin{array}{l}1092 \\
403\end{array}$ & 136 & 598 & 74 & 279 & 786 & 10353 \\
\hline 43 & $\begin{array}{l}\text { 1ransporte aquaviário } \\
\text { Transore }\end{array}$ & 0 & $\begin{array}{c}54 \\
5\end{array}$ & 165 & 1 & 0 & $\begin{array}{c}24 \\
0\end{array}$ & $\begin{array}{c}403 \\
1\end{array}$ & $\begin{array}{c}130 \\
0\end{array}$ & $\begin{array}{c}598 \\
4\end{array}$ & $\begin{array}{c}14 \\
1\end{array}$ & 181 & 220 & 6166 \\
\hline 44 & Atividades aux. dos transp. & 12 & 257 & $\begin{array}{l}103 \\
1304\end{array}$ & 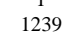 & 5 & 550 & $\begin{array}{c}1 \\
4151\end{array}$ & 121 & $\begin{array}{c}4 \\
541\end{array}$ & 76 & 243 & 2576 & $\begin{array}{l}0100 \\
27830\end{array}$ \\
\hline 45 & Comunicações & 54 & 623 & 2885 & 2049 & 15 & 1006 & 5678 & 401 & 1678 & 516 & 1819 & 5537 & 173479 \\
\hline 46 & Instituiç̃ôs financeiras & 38 & 654 & 3397 & 2492 & 13 & 1133 & 12760 & 364 & 1391 & 476 & 9538 & 5892 & 115780 \\
\hline 47 & Serv. prest. às famílias & 18 & 127 & 490 & 357 & 4 & 328 & 925 & 62 & 261 & 69 & 5421 & 1880 & 50965 \\
\hline 48 & Serv. prest. à empresas & 53 & 906 & 2997 & 2198 & 20 & 1789 & 5454 & 602 & 2520 & 2606 & 5525 & 16367 & 263359 \\
\hline 49 & Aluguel de imóveis & 9 & 141 & 639 & 469 & 3 & 169 & 1076 & 192 & 746 & 148 & 3485 & 1496 & 146168 \\
\hline 50 & Administracã̃o pública & 72 & $\begin{array}{l}1659 \\
1659\end{array}$ & 1118 & 811 & 15 & 655 & 2243 & 678 & 2193 & $\begin{array}{l}140 \\
1599\end{array}$ & 2299 & 6304 & 98795 \\
\hline 51 & Serv. priv. não mercantis & 0 & 0 & 0 & 0 & 0 & 0 & 0 & 0 & 0 & 0 & 0 & 0 & 0 \\
\hline
\end{tabular}


APÊNDICE 1 - Matriz insumo-produto inter-regional Mato Grosso x resto do Brasil / 1999.

\begin{tabular}{|c|c|c|c|c|c|c|c|c|c|c|c|c|c|}
\hline \multirow{2}{*}{\multicolumn{2}{|c|}{$\begin{array}{l}\text { Mato Grosso } \\
\text { Setores } \\
\end{array}$}} & \multicolumn{12}{|c|}{ Mato Grosso } \\
\hline & & 40 & 41 & 42 & 43 & 44 & 45 & 46 & 47 & 48 & 49 & 50 & 51 \\
\hline 1 & Cana-de-açúcar & & & & & & & & & & & & \\
\hline 2 & Soja & 0 & 1 & 0 & 0 & 1 & 0 & 0 & 700 & 0 & 0 & 547 & 19 \\
\hline 3 & Milho & 0 & 0 & 0 & 0 & 0 & 0 & 0 & 39 & 0 & 0 & 0 & 0 \\
\hline 4 & Fruticultura & 0 & 0 & 0 & 0 & 0 & 0 & 0 & 6359 & 0 & 0 & 6585 & 118 \\
\hline 5 & Outras culturas & 0 & 0 & 0 & 0 & 0 & 0 & 0 & 10518 & 0 & 0 & 8863 & 200 \\
\hline 6 & Aves & 0 & 0 & 0 & 0 & 0 & 0 & 0 & 2588 & 0 & 0 & 307 & 56 \\
\hline 7 & Bovinos & 0 & 1 & 0 & 0 & 1 & 0 & 0 & 3323 & 0 & 0 & 354 & 86 \\
\hline 8 & Suínos & 0 & 0 & 0 & 0 & 0 & 0 & 0 & 370 & 0 & 0 & 75 & 11 \\
\hline 9 & Outros pecuária & 0 & 1 & 0 & 0 & 0 & 0 & 0 & 3060 & 0 & 0 & 1212 & 31 \\
\hline 10 & Extrativismo vegetal & 0 & 0 & 0 & 0 & 2 & 0 & 0 & 0 & 0 & 0 & 3 & 0 \\
\hline 11 & Silvicultura & 0 & 0 & 0 & 0 & 0 & 0 & 0 & 0 & 0 & 0 & 0 & 0 \\
\hline 12 & Extrativismo animal & 0 & 0 & 0 & 0 & 0 & 0 & 0 & 1129 & 0 & 0 & 0 & 0 \\
\hline 13 & Extrat. Mineral & 110 & 27 & 8 & 3 & 39 & 151 & 703 & 813 & 1193 & 75 & 1834 & 81 \\
\hline 14 & Siderurgia & 9 & 3 & 9 & 0 & 3 & 188 & 31 & 1827 & 40 & 4 & 983 & 46 \\
\hline 15 & Maq. e implem. agrícolas & 12 & 1 & 1 & 0 & 5 & 13 & 18 & 146 & 30 & 9 & 172 & 6 \\
\hline 16 & Outras maq. e equip. & 3 & 0 & 0 & 0 & 2 & 4 & 5 & 44 & 9 & 3 & 51 & 2 \\
\hline 17 & Eletro-eletrônicos & 0 & 0 & 0 & 0 & 0 & 0 & 0 & 0 & 0 & 0 & 0 & 0 \\
\hline 18 & Peças e veículos & 0 & 0 & 0 & 0 & 0 & 0 & 0 & 0 & 0 & 0 & 0 & 0 \\
\hline 19 & Madeira e mobiliário & 17 & 6 & 2 & 1 & 24 & 29 & 225 & 128 & 404 & 13 & 1152 & 20 \\
\hline 20 & cel., papel e gráfica & 13 & 27 & 3 & 2 & 30 & 162 & 1183 & 278 & 7907 & 41 & 1586 & 29 \\
\hline 21 & Químicos diversos & 1 & 96 & 37 & 15 & 62 & 1 & 2 & 16 & 1 & 0 & 208 & 0 \\
\hline 22 & Âlcool & 767 & 15 & 10 & 4 & 35 & 1352 & 16 & 882 & 17 & 6 & 587 & 6 \\
\hline 23 & Refino do petróleo & -5 & 465 & 55 & 70 & 19 & 4 & 35 & 19 & 60 & 5 & 74 & 3 \\
\hline 24 & Adubos e fertilizantes & 0 & 0 & 0 & 0 & 0 & 1 & 1 & 8 & 0 & 0 & 5 & 0 \\
\hline 25 & Farmac. e veterinária & 1 & 1 & 0 & 0 & 1 & 1 & 2 & 10 & 2 & 1 & 12 & 0 \\
\hline 26 & Ind. têxtil e calçadista & 2 & 2 & 1 & 0 & 1 & 97 & 6 & 168 & 7 & 0 & 28 & 1 \\
\hline 27 & Indústria do café & 0 & 0 & 0 & 0 & 0 & 0 & 1 & 2 & 0 & 0 & 2 & 0 \\
\hline 28 & Benef. Prod. vegetais & 2 & 4 & 0 & 0 & 4 & 3 & 6 & 1190 & 3 & 0 & 623 & 28 \\
\hline 29 & Abate de outros animais & 9 & 25 & 0 & 0 & 21 & 13 & 25 & 13707 & 11 & 1 & 2338 & 423 \\
\hline 30 & Abate de bovinos & 9 & 26 & 0 & 0 & 22 & 14 & 25 & 8262 & 11 & 1 & 1665 & 243 \\
\hline 31 & Indústria de laticínios & 2 & 1 & 0 & 0 & 0 & 3 & 5 & 1230 & 2 & 0 & 1095 & 37 \\
\hline 32 & Fabricação de açúcar & 42 & 5 & 4 & 1 & 18 & 48 & 56 & 9850 & 76 & 28 & 771 & 184 \\
\hline 33 & Fab. óleos vegetais & 29 & 34 & 0 & 0 & 27 & 41 & 79 & 6862 & 34 & 3 & 239 & 140 \\
\hline 34 & Rações & 1 & 0 & 0 & 0 & 0 & 2 & 3 & 5 & 1 & 0 & 7 & 0 \\
\hline 35 & Outros prod. alimentares & 8 & 790 & 0 & 1 & 681 & 12 & 16 & 28336 & 7 & 1 & 498 & 207 \\
\hline 36 & Indústrias diversas & 43 & 21 & 6 & 4 & 18 & 80 & 1060 & 218 & 2095 & 67 & 1799 & 88 \\
\hline 37 & S.I.U.P. & 1712 & 193 & 201 & 28 & 874 & 1900 & 1892 & 23249 & 3517 & 1216 & 39888 & 858 \\
\hline 38 & Construção civil & 3124 & 318 & 96 & 56 & 382 & 2569 & 0 & 4598 & 1123 & 21143 & 12699 & 194 \\
\hline 39 & Comércio & 30336 & 2937 & 797 & 471 & 3805 & 5153 & 9855 & 57859 & 11462 & 317 & 90626 & 993 \\
\hline 40 & Transporte rodoviário & 33950 & 2144 & 490 & 539 & 1854 & 1162 & 1486 & 6555 & 600 & 26 & 10813 & 128 \\
\hline 41 & Transporte aéreo & 9731 & 4971 & 401 & 353 & 1058 & 69 & 579 & 1768 & 969 & 1 & 646 & 4 \\
\hline 42 & Transporte ferroviário & 2872 & 515 & 860 & 104 & 312 & 3 & 18 & 525 & 6 & 0 & 1468 & 2 \\
\hline 43 & Transporte aquaviário & 1710 & 307 & 70 & 607 & 186 & 2 & 371 & 322 & 642 & 11 & 7917 & 105 \\
\hline 44 & Atividades aux. dos transp. & 7684 & 1372 & 315 & 278 & 2815 & 243 & 2981 & 1477 & 1752 & 6 & 3729 & 37 \\
\hline 45 & Comunicações & 10348 & 1543 & 426 & 210 & 1445 & 3271 & 7605 & 12912 & 12951 & 445 & 17880 & 348 \\
\hline 46 & Instituições financeiras & 13737 & 1277 & 320 & 171 & 856 & 4554 & 32542 & 6280 & 3356 & 1088 & 16272 & 9 \\
\hline 47 & Serv. prest. à famílias & 2550 & 268 & 77 & 45 & 299 & 6051 & 16982 & 13428 & 1612 & 27 & 97892 & 167 \\
\hline 48 & Serv. prest. às empresas & 10938 & 1865 & 232 & 137 & 1041 & 4754 & 25829 & 12335 & 16519 & 346 & 114481 & 377 \\
\hline 49 & Aluguel de imóveis & 2042 & 531 & 15 & 19 & 380 & 2877 & 5539 & 3058 & 2385 & 178 & 10827 & 712 \\
\hline 50 & Administração pública & 4039 & 774 & 95 & 56 & 467 & 1976 & 10696 & 5084 & 12750 & 183 & 43505 & 200 \\
\hline 51 & Serv. priv. não mercantis & 0 & 0 & 0 & 0 & 0 & 0 & 0 & 0 & 0 & 0 & 0 & 0 \\
\hline
\end{tabular}


APÊNDICE 1 - Matriz insumo-produto inter-regional Mato Grosso x resto do Brasil / 1999.

\begin{tabular}{|c|c|c|c|c|c|c|c|c|c|c|c|c|c|c|}
\hline \multirow{2}{*}{\multicolumn{2}{|c|}{$\begin{array}{l}\text { Mato Grosso } \\
\text { Setores } \\
\end{array}$}} & \multicolumn{13}{|c|}{ resto do Brasil } \\
\hline & & 1 & 2 & 3 & 4 & 5 & 6 & 7 & 8 & 9 & 10 & 11 & 12 & 13 \\
\hline 1 & Cana-de-açúcar & & & & & & & & & & & & & \\
\hline 2 & Soja & 1 & 42 & 1 & 168 & 1146 & 0 & 1 & 0 & 1825 & 0 & 0 & 0 & 1 \\
\hline 3 & Milho & 18 & 5 & 33 & 55 & 907 & 2831 & 2466 & 2744 & 4596 & 29 & 37 & 0 & 0 \\
\hline 4 & Fruticultura & 0 & 1 & 88 & 219 & 1310 & 0 & 0 & 0 & 957 & 0 & 0 & 0 & 0 \\
\hline 5 & Outras culturas & 639 & 25 & 128 & 1809 & 13674 & 114 & 3292 & 0 & 21524 & 607 & 755 & 15 & 24 \\
\hline 6 & Aves & 1 & 0 & 1 & 3 & 55 & 1820 & 62 & 0 & 244 & 5 & 5 & 0 & 0 \\
\hline 7 & Bovinos & 0 & 1 & 8 & 7 & 33 & 50 & 32564 & 0 & 1967 & 15 & 24 & 0 & 0 \\
\hline 8 & Suínos & 0 & 0 & 0 & 0 & 0 & 0 & 0 & 21 & 0 & 0 & 0 & 0 & 0 \\
\hline 9 & Outros pecuária & 0 & 2 & 1436 & 1142 & 6661 & 0 & 1545 & 0 & 457 & 0 & 0 & 0 & 0 \\
\hline 10 & Extrativismo vegetal & 2 & 0 & $\begin{array}{c}1400 \\
2\end{array}$ & 2 & 13 & 1 & 2 & 0 & 1 & 9 & 25 & 0 & 2 \\
\hline 11 & Silvicultura & 0 & 0 & 0 & 0 & 0 & 0 & 0 & 0 & 0 & 0 & 0 & 0 & 0 \\
\hline 12 & Extrativismo animal & 0 & 0 & 0 & 0 & 0 & 0 & 0 & 0 & 0 & 0 & 0 & 0 & 0 \\
\hline 13 & Extrat. Mineral & 1217 & 9 & 1042 & 1025 & 6031 & 2 & 1013 & 0 & 539 & 0 & 442 & 23 & 1062 \\
\hline 14 & Siderurgia & 26 & 0 & 24 & 23 & 142 & 1 & 28 & 1 & 19 & 2 & 10 & 2 & 519 \\
\hline 15 & Maq. e implem. agrícolas & 0 & 0 & 0 & 0 & 0 & 0 & 0 & 0 & 0 & 0 & 0 & 0 & 1 \\
\hline 16 & Outras maq. e equip. & 0 & 0 & 0 & 0 & 0 & 0 & 1 & 0 & 1 & 0 & 0 & 0 & 7 \\
\hline 17 & Eletro-eletrônicos & 0 & 0 & 0 & 0 & 0 & 0 & 0 & 0 & 0 & 0 & 0 & 0 & 0 \\
\hline 18 & Peças e veículos & 0 & 0 & 0 & 0 & 0 & 0 & 0 & 0 & 0 & 0 & 0 & 0 & 0 \\
\hline 19 & Madeira e mobiliário & 27 & 1 & 36 & 168 & 1107 & 319 & 32 & 20 & 39 & 10 & 26 & 9 & 465 \\
\hline 20 & cel., papel e gráfica & 0 & 0 & 0 & 0 & 3 & 0 & 2 & 0 & 1 & 0 & 0 & 1 & 4 \\
\hline 21 & Químicos diversos & 189 & 10 & 304 & 90 & 371 & 124 & 253 & 3 & 169 & 13 & 23 & 0 & 187 \\
\hline 22 & Âlcool & 23 & 1 & 36 & 11 & 49 & 14 & 33 & 0 & 24 & 2 & 3 & 1 & 21 \\
\hline 23 & Refino do petróleo & 7 & 4 & 17 & 18 & 82 & 0 & 69 & 4 & 96 & 24 & 1 & 60 & 102 \\
\hline 24 & Adubos e fertilizantes & 10 & 17 & 76 & 46 & $\begin{array}{l}02 \\
558\end{array}$ & 2 & 236 & 0 & 536 & 36 & 1 & 0 & 0 \\
\hline 25 & Farmac. e veterinária & 2 & 0 & 4 & 1 & 6 & 3 & 20 & 2 & 5 & 0 & 0 & 0 & 2 \\
\hline 26 & Ind têxtil e calcadista & 0 & 0 & 0 & 0 & 5 & 1 & 13 & 0 & 8 & 0 & 0 & 0 & 2 \\
\hline 27 & Indústria do café & 0 & 0 & 0 & 0 & 0 & 0 & 0 & 0 & 0 & 0 & 0 & 0 & 0 \\
\hline 28 & Benef. Prod. vegetais & 2 & 0 & 2 & 1 & 7 & 18 & 17 & 4 & 8 & 1 & 1 & 0 & 1 \\
\hline 29 & Abate de outros animais & 0 & 0 & 4 & 3 & 17 & 0 & 4 & 0 & 1 & 0 & 0 & 0 & 1 \\
\hline 30 & Abate de bovinos & 0 & 0 & 9 & 7 & 40 & 0 & 10 & 0 & 3 & 0 & 0 & 0 & 1 \\
\hline 31 & Indústria de laticínios & 0 & 0 & 0 & 0 & 0 & 0 & 0 & 0 & 0 & 0 & 0 & 0 & 0 \\
\hline 32 & Fabricação de açúcar & 0 & 0 & 0 & 0 & 2 & 0 & 0 & 0 & 6 & 0 & 0 & 8 & 0 \\
\hline 33 & Fab. óleos vegetais & 131 & 2 & 66 & 25 & 131 & 16042 & 1958 & 515 & 23 & 15 & 26 & 0 & 25 \\
\hline 34 & Rações & 2 & 1 & 3 & 4 & 52 & 299 & 2232 & 725 & 8 & 6 & 4 & 0 & 0 \\
\hline 35 & Outros prod. alimentares & 2 & 0 & 2 & 1 & 6 & 7 & 17 & 2 & 5 & 1 & 1 & 0 & 16 \\
\hline 36 & Indústrias diversas & 2 & 0 & 2 & 1 & 3 & 1 & 2 & 0 & 2 & 0 & 0 & 45 & 44 \\
\hline 37 & S.I.U.P. & 97 & 0 & 22 & 13 & 39 & 2108 & 15 & 3 & 17 & 1 & 15 & 0 & 5777 \\
\hline 38 & Construução civil & 1 & 0 & 0 & 0 & 0 & 1 & 0 & 0 & 0 & 0 & 0 & 0 & 738 \\
\hline 39 & Comércio & 6341 & 43 & 5126 & 117 & 1404 & 6316 & 2410 & 169 & 1359 & 219 & 829 & 153 & 9058 \\
\hline 40 & Transporte rodoviário & 552 & 0 & 185 & 8 & 201 & 820 & 208 & 22 & 147 & 30 & 311 & 20 & 1343 \\
\hline 41 & Transporte aéreo & 2 & 0 & 1 & 1 & 1 & 2 & 0 & 0 & 0 & 0 & 1 & 0 & 203 \\
\hline 42 & Transporte ferroviário & 48 & 0 & 68 & 0 & 18 & 88 & 6 & 1 & 5 & 1 & 9 & 1 & 92 \\
\hline 43 & $\begin{array}{l}\text { 11ransporte lirtoviario } \\
\text { Transporte auaviário }\end{array}$ & 32 & 0 & 43 & 16 & 20 & 45 & $\begin{array}{l}0 \\
5\end{array}$ & 1 & 5 & 1 & 11 & 0 & $\begin{array}{l}92 \\
123\end{array}$ \\
\hline 44 & Atividades aux. dos transp. & 0 & 0 & 0 & 0 & 0 & 1 & 0 & 0 & 0 & 0 & 0 & 0 & 67 \\
\hline 45 & Comunicações & 0 & 0 & 0 & 0 & 4 & 0 & 4 & 1 & 3 & 1 & 2 & 10 & 391 \\
\hline 46 & Instituiç̄oses financeiras & 0 & 0 & 1 & 2 & 26 & 1 & 22 & 3 & 17 & 3 & 0 & 2 & 97 \\
\hline 47 & Serv. prest. às famílias & 2 & 0 & 3 & 2 & 10 & 67 & 26 & 0 & 9 & 0 & 3 & 0 & 423 \\
\hline 48 & Serv. prest. às empresas & 20 & 1 & 1 & 2 & 60 & 45 & 60 & 7 & 42 & 9 & 62 & 5 & 3128 \\
\hline 49 & Aluguel de imóveis & 0 & 0 & 0 & 0 & 0 & 0 & 2 & 0 & 0 & 0 & 02 & 0 & 51 \\
\hline 50 & Administracãão pública & 37 & 6 & 75 & 40 & 320 & 35 & 170 & 6 & 240 & 17 & 30 & 13 & 1240 \\
\hline 51 & Serv. priv. não mercantis & 0 & 0 & 0 & 0 & 0 & 0 & 0 & 0 & 0 & 0 & 0 & 0 & 0 \\
\hline
\end{tabular}


APÊNDICE 1 - Matriz insumo-produto inter-regional Mato Grosso x resto do Brasil / 1999.

\begin{tabular}{|c|c|c|c|c|c|c|c|c|c|c|c|c|c|c|}
\hline \multirow{2}{*}{\multicolumn{2}{|c|}{$\begin{array}{l}\text { Mato Grosso } \\
\text { Setores } \\
\end{array}$}} & \multicolumn{13}{|c|}{ resto do Brasil } \\
\hline & & 14 & 15 & 16 & 17 & 18 & 19 & 20 & 21 & 22 & 23 & 24 & 25 & 26 \\
\hline 1 & Cana-de-açúcar & & & & & & & & & & & & & \\
\hline 2 & Soja & 2 & 0 & 0 & 0 & 0 & 0 & 15 & 26 & 0 & 2 & 3 & 12 & 14 \\
\hline 3 & Milho & 0 & 0 & 0 & 0 & 0 & 0 & 0 & 0 & 0 & 0 & 0 & 1 & 0 \\
\hline 4 & Fruticultura & 0 & 0 & 0 & 0 & 0 & 0 & 1 & 1 & 0 & 0 & 0 & 1 & 1 \\
\hline 5 & Outras culturas & 0 & 0 & 0 & 0 & 0 & 0 & 2 & 1257 & 0 & 0 & 0 & 26 & 485891 \\
\hline 6 & Aves & 0 & 0 & 0 & 0 & 0 & 0 & 0 & 0 & 0 & 0 & 0 & 0 & 0 \\
\hline 7 & Bovinos & 0 & 0 & 0 & 0 & 0 & 0 & 0 & 5 & 0 & 0 & 0 & 99 & 0 \\
\hline 8 & Suínos & 0 & 0 & 0 & 0 & 0 & 0 & 0 & 6 & 0 & 0 & 0 & 14 & 385 \\
\hline 9 & Outros pecuária & 0 & 0 & 0 & 0 & 0 & 0 & 0 & 1822 & 0 & 0 & 0 & 763 & 892 \\
\hline 10 & Extrativismo vegetal & 7895 & 1 & 8 & 15 & 25 & 121039 & 31 & 5087 & 0 & 4 & 6 & 12 & 8 \\
\hline 11 & Silvicultura & 4 & 0 & 0 & 0 & 0 & 129 & 0 & 0 & 0 & 0 & 0 & 0 & 0 \\
\hline 12 & Extrativismo animal & 0 & 0 & 0 & 0 & 0 & 0 & 0 & 0 & 0 & 0 & 0 & 0 & 0 \\
\hline 13 & Extrat. Mineral & 96240 & 0 & 22 & 2400 & 68 & 6 & 4582 & 29402 & 7 & 2437 & 3845 & 2604 & 452 \\
\hline 14 & Siderurgia & 8096 & 60 & 2897 & 1368 & 5181 & 189 & 132 & 1381 & 3 & 872 & 142 & 186 & 191 \\
\hline 15 & Maq. e implem. agrícolas & 5 & 0 & 10 & 3 & 25 & 54 & 31 & 3 & 111 & 8 & 0 & 0 & 3 \\
\hline 16 & Outras maq. e equip. & 5 & 0 & 12 & 9 & 45 & 1 & 2 & 13 & 0 & 39 & 0 & 0 & 11 \\
\hline 17 & Eletro-eletrônicos & 1 & 0 & 4 & 3 & 1 & 0 & 0 & 0 & 0 & 0 & 0 & 0 & 0 \\
\hline 18 & Peças e veículos & 1 & 0 & 7 & 0 & 148 & 0 & 0 & 0 & 0 & 0 & 0 & 0 & 0 \\
\hline 19 & Madeira e mobiliário & 5131 & 169 & 2186 & 2962 & 6386 & 37182 & 7428 & 1540 & 14 & 277 & 12 & 71 & 2041 \\
\hline 20 & cel., papel e gráfica & 216 & 1 & 33 & 27 & 27 & 11 & 428 & 66 & 0 & 38 & 6 & 36 & 90 \\
\hline 21 & Químicos diversos & 1431 & 15 & 271 & 231 & 1980 & 299 & 1268 & 1430 & 0 & 1382 & 307 & 744 & 1389 \\
\hline 22 & Âlcool & 131 & 1 & 14 & 16 & 96 & 37 & 64 & 457 & 17 & 3519 & 46 & 157 & 60 \\
\hline 23 & Refino do petróleo & 89 & -1 & -14 & 134 & 194 & 208 & 33 & 2049 & -4 & 3663 & 31 & 85 & 58 \\
\hline 24 & Adubos e fertilizantes & 3 & 0 & 1 & 1 & 2 & 1 & 1 & 25 & 0 & 37 & 493 & 6 & 2 \\
\hline 25 & Farmac. e veterinária & 9 & 0 & 1 & 1 & 1 & 1 & 5 & 23 & 1 & 11 & 4 & 32 & 5 \\
\hline 26 & Ind. têxtil e calçadista & 5 & 0 & 6 & 6 & 86 & 22 & 4 & 15 & 0 & 13 & 2 & 5 & 1699 \\
\hline 27 & Indústria do café & 0 & 0 & 0 & 0 & 0 & 0 & 0 & 0 & 0 & 0 & 0 & 0 & 0 \\
\hline 28 & Benef. Prod. vegetais & 6 & 0 & 1 & 1 & 2 & 1 & 14 & 49 & 0 & 10 & 4 & 81 & 17 \\
\hline 29 & Abate de outros animais & 3 & 0 & 2 & 0 & 2 & 1 & 2 & 110 & 0 & 3 & 0 & 258 & 7246 \\
\hline 30 & Abate de bovinos & 3 & 0 & 2 & 0 & 3 & 1 & 2 & 13 & 0 & 3 & 0 & 491 & 15 \\
\hline 31 & Indústria de laticínios & 2 & 0 & 1 & 0 & 1 & 0 & 1 & 3 & 0 & 2 & 0 & 6 & 2 \\
\hline 32 & Fabricação de açúcar & 2 & 0 & 1 & 0 & 5 & 1 & 2 & 29 & 2 & 27 & 0 & 11 & 7 \\
\hline 33 & Fab. óleos vegetais & 105 & 1 & 15 & 8 & 21 & 16 & 56 & 12485 & 1 & 2985 & 42 & 49188 & 115 \\
\hline 34 & Rações & 1 & 0 & 0 & 0 & 0 & 0 & 1 & 2 & 0 & 2 & 0 & 7 & 9 \\
\hline 35 & Outros prod. alimentares & 11 & 0 & 14 & 7 & 21 & 15 & 7 & 44 & 0 & 31 & 2 & 54 & 65 \\
\hline 36 & Indústrias diversas & 336 & 1 & 24 & 18 & 105 & 8 & 209 & 107 & 13 & 147 & 20 & 14 & 130 \\
\hline 37 & S.I.U.P. & 23833 & 197 & 3566 & 1311 & 1539 & 1084 & 6823 & 7496 & 2510 & 10631 & 325 & 760 & 6554 \\
\hline 38 & Construção civil & 1070 & 29 & 606 & 112 & 377 & 80 & 527 & 443 & 126 & 1232 & 62 & 176 & 520 \\
\hline 39 & Comércio & 93911 & 2131 & 39077 & 19266 & 74139 & 14520 & 53714 & 34414 & 4314 & 77754 & 7999 & 30756 & 89998 \\
\hline 40 & Transporte rodoviário & 13452 & 145 & 2539 & 1425 & 6344 & 1512 & 3421 & 2914 & 1707 & 851 & 87 & 3127 & 7653 \\
\hline 41 & Transporte aéreo & 2168 & 5 & 196 & 51 & 269 & 19 & 187 & 142 & 2 & 12 & 447 & 31 & 10 \\
\hline 42 & Transporte ferroviário & 984 & 8 & 228 & 119 & 282 & 30 & 300 & 449 & 2 & 10560 & 215 & 239 & 82 \\
\hline 43 & Transporte aquaviário & 0 & 0 & 2 & 7 & 0 & 0 & 1 & 0 & 0 & 0 & 0 & 0 & 0 \\
\hline 44 & Atividades aux. dos transp. & 858 & 11 & 195 & 30 & 494 & 57 & 199 & 224 & 73 & 2096 & 99 & 136 & 453 \\
\hline 45 & Comunicações & 1662 & 17 & 2721 & 143 & 2248 & 89 & 1444 & 934 & 72 & 4165 & 233 & 38 & 3017 \\
\hline 46 & Instituiçōes financeiras & 126 & 1 & 140 & 63 & 1688 & 15 & 15 & 494 & 0 & 3585 & 5 & 1 & 806 \\
\hline 47 & Serv. prest. às famílias & 1291 & 41 & 874 & 161 & 576 & 152 & 601 & 373 & 84 & 793 & 80 & 230 & 978 \\
\hline 48 & Serv. prest. à empresas & 2179 & 61 & 1689 & 203 & 3296 & 161 & 1927 & 891 & 153 & 3510 & 189 & 1781 & 2946 \\
\hline 49 & Aluguel de imóveis & 184 & 1 & 211 & 12 & 104 & 14 & 173 & 73 & 4 & 321 & 22 & 4 & 579 \\
\hline 50 & Administração pública & 1373 & 29 & 815 & 274 & 2391 & 505 & 4975 & 778 & 61 & 2123 & 264 & 917 & 1912 \\
\hline 51 & Serv. priv. não mercantis & 0 & 0 & 0 & 0 & 0 & 0 & 0 & 0 & 0 & 0 & 0 & 0 & 0 \\
\hline
\end{tabular}


APÊNDICE 1 - Matriz insumo-produto inter-regional Mato Grosso x resto do Brasil / 1999.

\begin{tabular}{|c|c|c|c|c|c|c|c|c|c|c|c|c|c|c|}
\hline \multirow{2}{*}{\multicolumn{2}{|c|}{$\begin{array}{l}\text { Mato Grosso } \\
\text { Setores } \\
\end{array}$}} & \multicolumn{13}{|c|}{ resto do Brasil } \\
\hline & & 27 & 28 & 29 & 30 & 31 & 32 & 33 & 34 & 35 & 36 & 37 & 38 & 39 \\
\hline 1 & Cana-de-açúcar & & & & & & & & & & & & & \\
\hline 2 & Soja & 1 & 20385 & 5 & 6 & 7 & 0 & 676327 & 15 & 47047 & 0 & 0 & 0 & 0 \\
\hline 3 & Milho & 0 & 10454 & 26 & 0 & 0 & 0 & 1 & 5887 & 16441 & 0 & 0 & 0 & 0 \\
\hline 4 & Fruticultura & 0 & 21153 & 0 & 0 & 77 & 0 & 0 & 1 & 3734 & 0 & 0 & 0 & 0 \\
\hline 5 & Outras culturas & 21087 & 405906 & 324 & 107 & 1 & 65 & 1460 & 3 & 4066 & 0 & 0 & 0 & 0 \\
\hline 6 & Aves & 0 & 1 & 17744 & 0 & 0 & 0 & 0 & 0 & 1080 & 0 & 0 & 0 & 0 \\
\hline 7 & Bovinos & 0 & 362 & 0 & 293215 & 53506 & 0 & 137 & 3 & 739 & 25 & 0 & 0 & 0 \\
\hline 8 & Suínos & 0 & 0 & 79958 & 0 & 0 & 0 & 0 & 0 & 58 & 0 & 0 & 0 & 0 \\
\hline 9 & Outros pecuária & 0 & 2 & 56 & 0 & 152 & 0 & 14516 & 16226 & 14859 & 1043 & 539 & 0 & 0 \\
\hline 10 & Extrativismo vegetal & 0 & 92 & 2 & 1 & 0 & 0 & 0 & 8 & 16 & 50 & 0 & 367 & 1 \\
\hline 11 & Silvicultura & 0 & 0 & 0 & 0 & 0 & 0 & 0 & 0 & 0 & 0 & 0 & 2 & 0 \\
\hline 12 & Extrativismo animal & 0 & 0 & 0 & 0 & 0 & 0 & 0 & 0 & 0 & 0 & 0 & 0 & 0 \\
\hline 13 & Extrat. Mineral & 15 & 342 & 293 & 131 & 8 & 7 & 167 & 4089 & 7530 & 25232 & 221 & 27118 & 8 \\
\hline 14 & Siderurgia & 110 & 852 & 24 & 9 & 27 & 45 & 10 & 89 & 632 & 593 & 26 & 10972 & 8 \\
\hline 15 & Maq. e implem. agrícolas & 0 & 2 & 0 & 0 & 0 & 137 & 0 & 0 & 1 & 0 & 36 & 7 & 0 \\
\hline 16 & Outras maq. e equip. & 0 & 4 & 1 & 0 & 0 & 0 & 0 & 0 & 1 & 0 & 20 & 7 & 1 \\
\hline 17 & Eletro-eletrônicos & 0 & 0 & 0 & 0 & 0 & 0 & 0 & 0 & 0 & 0 & 1 & 5 & 0 \\
\hline 18 & Peças e veículos & 0 & 0 & 0 & 0 & 0 & 0 & 0 & 0 & 0 & 0 & 0 & 1 & 0 \\
\hline 19 & Madeira e mobiliário & 29 & 311 & 301 & 119 & 20 & 10 & 0 & 454 & 1258 & 3496 & 28 & 87929 & 25 \\
\hline 20 & cel., papel e gráfica & 12 & 94 & 10 & 4 & 12 & 2 & 0 & 1 & 114 & 14 & 84 & 18 & 132 \\
\hline 21 & Químicos diversos & 6 & 69 & 9 & 2 & 17 & 66 & 17 & 99 & 269 & 198 & 43 & 1704 & 1 \\
\hline 22 & Âlcool & 1 & 43 & 1 & 0 & 4 & 14 & 1 & 23 & 301 & 22 & 77 & 53 & 8438 \\
\hline 23 & Refino do petróleo & -11 & -83 & 11 & 5 & -5 & -12 & 4 & -11 & 25 & 51 & 998 & 178 & 1700 \\
\hline 24 & Adubos e fertilizantes & 0 & 1 & 0 & 0 & 0 & 0 & 0 & 0 & 1 & 1 & 0 & 1 & 0 \\
\hline 25 & Farmac. e veterinária & 0 & 3 & 1 & 0 & 1 & 1 & 0 & 3 & 20 & 1 & 2 & 1 & 0 \\
\hline 26 & Ind. têxtil e calçadista & 2 & 10 & 2 & 5 & 3 & 1 & 4 & 1 & 15 & 12 & 2 & 10 & 4 \\
\hline 27 & Indústria do café & 506 & 1 & 0 & 0 & 0 & 0 & 0 & 0 & 0 & 0 & 0 & 0 & 0 \\
\hline 28 & Benef. Prod. vegetais & 7 & 778 & 16 & 5 & 16 & 1 & 8 & 78 & 1619 & 1 & 0 & 1 & 0 \\
\hline 29 & Abate de outros animais & 1 & 25 & 880 & 0 & 1 & 0 & 44 & 42 & 2159 & 30 & 2 & 0 & 1 \\
\hline 30 & Abate de bovinos & 1 & 231 & 0 & 1450 & 1 & 0 & 904 & 97 & 3385 & 154 & 4 & 0 & 1 \\
\hline 31 & Indústria de laticínios & 0 & 37 & 1 & 1 & 211 & 0 & 1 & 4 & 109 & 0 & 0 & 0 & 0 \\
\hline 32 & Fabricação de açúcar & 0 & 1382 & 0 & 0 & 93 & 570 & 0 & 82 & 1855 & 0 & 111 & 0 & 25 \\
\hline 33 & Fab. óleos vegetais & 3 & 7514 & 30 & 12 & 1950 & 11 & 1081 & 16 & 132661 & 12 & 6 & 13 & 2 \\
\hline 34 & Rações & 0 & 2 & 105 & 35 & 0 & 0 & 2 & 5 & 3 & 0 & 0 & 0 & 0 \\
\hline 35 & Outros prod. alimentares & 7 & 149 & 1 & 0 & 6 & 1 & 5 & 6 & 291 & 5 & 1 & 1 & 25 \\
\hline 36 & Indústrias diversas & 25 & 29 & 3 & 2 & 14 & 10 & 0 & 2 & 20 & 32 & 139 & 137 & 11 \\
\hline 37 & S.I.U.P. & 462 & 2958 & 150 & 26 & 751 & 1854 & 109 & 953 & 2213 & 602 & 18628 & 763 & 3708 \\
\hline 38 & Construção civil & 78 & 268 & 13 & 4 & 109 & 356 & 0 & 52 & 152 & 78 & 661 & 0 & 37 \\
\hline 39 & Comércio & 12166 & 78404 & 1665 & 484 & 11378 & 12772 & 216 & 14490 & 34685 & 10199 & 5078 & 43572 & 3768 \\
\hline 40 & Transporte rodoviário & 1423 & 6434 & 250 & 98 & 1741 & 2424 & 10 & 829 & 3568 & 778 & 106 & 3241 & 601 \\
\hline 41 & Transporte aéreo & 11 & 97 & 1 & 0 & 14 & 39 & 24 & 76 & 28 & 107 & 24 & 143 & 1215 \\
\hline 42 & Transporte ferroviário & 4 & 51 & 2 & 0 & 34 & 7 & 6 & 103 & 201 & 85 & 65 & 160 & 359 \\
\hline 43 & Transporte aquaviário & 0 & 8 & 2 & 0 & 0 & 0 & 0 & 0 & 2 & 1 & 31 & 45 & 219 \\
\hline 44 & Atividades aux. dos transp. & 82 & 387 & 16 & 6 & 92 & 119 & 1 & 34 & 209 & 39 & 51 & 41 & 49 \\
\hline 45 & Comunicações & 508 & 1299 & 58 & 17 & 242 & 181 & 2 & 2 & 593 & 27 & 134 & 131 & 340 \\
\hline 46 & Instituiçōes financeiras & 101 & 414 & 32 & 10 & 2 & 0 & 2 & 1 & 20 & 9 & 276 & 56 & 165 \\
\hline 47 & Serv. prest. às famílias & 138 & 453 & 17 & 4 & 166 & 215 & 6 & 84 & 228 & 119 & 1997 & 525 & 356 \\
\hline 48 & Serv. prest. às empresas & 575 & 2149 & 59 & 17 & 518 & 590 & 1 & 231 & 1252 & 1897 & 1006 & 320 & 511 \\
\hline 49 & Aluguel de imóveis & 43 & 147 & 6 & 2 & 23 & 14 & 0 & 0 & 137 & 2 & 154 & 15 & 130 \\
\hline 50 & Administração pública & 325 & 2381 & 106 & 30 & 236 & 233 & 164 & 285 & 1089 & 775 & 494 & 207 & 697 \\
\hline 51 & Serv. priv. não mercantis & 0 & 0 & 0 & 0 & 0 & 0 & 0 & 0 & 0 & 0 & 0 & 0 & 0 \\
\hline
\end{tabular}


APÊNDICE 1 - Matriz insumo-produto inter-regional Mato Grosso x resto do Brasil / 1999.

\begin{tabular}{|c|c|c|c|c|c|c|c|c|c|c|c|c|c|}
\hline \multirow{2}{*}{\multicolumn{2}{|c|}{$\begin{array}{l}\text { Mato Grosso } \\
\text { Setores } \\
\end{array}$}} & \multicolumn{12}{|c|}{ resto do Brasil } \\
\hline & & 40 & 41 & 42 & 43 & 44 & 45 & 46 & 47 & 48 & 49 & 50 & 51 \\
\hline 1 & Cana-de-açúcar & & & & & & & & & & & & \\
\hline 2 & Soja & 0 & 0 & 0 & 0 & 0 & 0 & 0 & 100 & 0 & 0 & 106 & 2 \\
\hline 3 & Milho & 0 & 0 & 0 & 0 & 0 & 0 & 0 & 13 & 0 & 0 & 0 & 0 \\
\hline 4 & Fruticultura & 0 & 0 & 0 & 0 & 0 & 0 & 0 & 4059 & 0 & 0 & 3647 & 132 \\
\hline 5 & Outras culturas & 0 & 0 & 0 & 0 & 0 & 0 & 0 & 10857 & 0 & 0 & 9745 & 263 \\
\hline 6 & Aves & 0 & 0 & 0 & 0 & 0 & 0 & 0 & 854 & 0 & 0 & 149 & 38 \\
\hline 7 & Bovinos & 0 & 0 & 0 & 0 & 0 & 0 & 0 & 2652 & 0 & 0 & 491 & 110 \\
\hline 8 & Suínos & 0 & 0 & 0 & 0 & 0 & 0 & 0 & 182 & 0 & 0 & 14 & 9 \\
\hline 9 & Outros pecuária & 0 & 0 & 0 & 0 & 0 & 0 & 0 & 4759 & 0 & 0 & 2331 & 67 \\
\hline 10 & Extrativismo vegetal & 0 & 0 & 0 & 0 & 0 & 0 & 0 & 1 & 0 & 0 & 8 & 0 \\
\hline 11 & Silvicultura & 0 & 0 & 0 & 0 & 0 & 0 & 0 & 0 & 0 & 0 & 0 & 0 \\
\hline 12 & Extrativismo animal & 0 & 0 & 0 & 0 & 0 & 0 & 0 & 1048 & 0 & 0 & 0 & 0 \\
\hline 13 & Extrat. Mineral & 2 & 2 & 0 & 0 & 0 & 13 & 454 & 34 & 67 & 13 & 214 & 4 \\
\hline 14 & Siderurgia & 5 & 1 & 8 & 0 & 4 & 38 & 17 & 534 & 3 & 1 & 245 & 4 \\
\hline 15 & Maq. e implem. agrícolas & 1 & 0 & 0 & 0 & 0 & 1 & 4 & 2 & 1 & 0 & 2 & 0 \\
\hline 16 & Outras maq. e equip. & 0 & 0 & 0 & 0 & 0 & 2 & 1 & 2 & 1 & 0 & 2 & 0 \\
\hline 17 & Eletro-eletrônicos & 0 & 0 & 0 & 0 & 0 & 4 & 0 & 1 & 0 & 0 & 1 & 0 \\
\hline 18 & Pecas e veículos & 14 & 2 & 1 & 0 & 7 & 2 & 0 & 13 & 0 & 0 & 6 & 0 \\
\hline 19 & Madeira e mobiliário & 14 & 5 & 1 & 1 & 4 & 20 & 161 & 59 & 25 & 10 & 2038 & 2 \\
\hline 20 & cel., papel e gráfica & 5 & 4 & 0 & 0 & 1 & 91 & 689 & 100 & 657 & 13 & 606 & 4 \\
\hline 21 & Químicos diversos & 87 & 25 & 7 & 3 & 20 & 2 & 1 & 596 & 0 & 0 & 228 & 0 \\
\hline 22 & Âlcool & 66 & 6 & 4 & 2 & 8 & 256 & 3 & 112 & 1 & 0 & 90 & 0 \\
\hline 23 & Refino do petróleo & 643 & 497 & 37 & 72 & 43 & -6 & 17 & 46 & 1 & 0 & 49 & 0 \\
\hline 24 & Adubos e fertilizantes & 0 & 0 & 0 & 0 & 0 & 0 & 0 & 2 & 0 & 0 & 1 & 0 \\
\hline 25 & Farmac. e veterinária & 0 & 0 & 0 & 0 & 0 & 0 & 1 & 29 & 0 & 0 & 38 & 0 \\
\hline 26 & Ind. têxtil e calçadista & 6 & 3 & 1 & 0 & 1 & 17 & 3 & 147 & 0 & 1 & 24 & 2 \\
\hline 27 & Indústria do café & 0 & 0 & 0 & 0 & 0 & 0 & 0 & 15 & 0 & 0 & 2 & 0 \\
\hline 28 & Benef. Prod. vegetais & 0 & 1 & 0 & 0 & 0 & 0 & 3 & 363 & 0 & 0 & 143 & 4 \\
\hline 29 & Abate de outros animais & 0 & 5 & 0 & 0 & 1 & 0 & 11 & 10044 & 0 & 0 & 992 & 498 \\
\hline 30 & Abate de bovinos & 0 & 5 & 0 & 0 & 1 & 0 & 11 & 15345 & 0 & 0 & 2859 & 648 \\
\hline 31 & Indústria de laticínios & 0 & 0 & 0 & 0 & 0 & 0 & 2 & 79 & 0 & 0 & 183 & 2 \\
\hline 32 & Fabricação de açúcar & 0 & 0 & 0 & 0 & 0 & 1 & 8 & 1181 & 0 & 0 & 39 & 21 \\
\hline 33 & Fab. óleos vegetais & 0 & 6 & 0 & 0 & 3 & 0 & 36 & 9505 & 0 & 0 & 55 & 394 \\
\hline 34 & Rações & 0 & 0 & 0 & 0 & 0 & 0 & 2 & 1 & 0 & 0 & 1 & 0 \\
\hline 35 & Outros prod. alimentares & 0 & 162 & 0 & 0 & 18 & 1 & 7 & 14592 & 0 & 0 & 179 & 94 \\
\hline 36 & Indústrias diversas & 5 & 4 & 1 & 1 & 0 & 29 & 796 & 53 & 133 & 25 & 410 & 8 \\
\hline 37 & S.I.U.P. & 217 & 7 & 6 & 1 & 644 & 1301 & 2802 & 3790 & 2378 & 1363 & 6883 & 398 \\
\hline 38 & Construção civil & 3 & 11 & 3 & 2 & 157 & 1503 & 0 & 619 & 555 & 27166 & 228 & 61 \\
\hline 39 & Comércio & 13874 & 1787 & 494 & 269 & 10928 & 9563 & 18749 & 27108 & 17703 & 983 & 20453 & 1165 \\
\hline 40 & Transporte rodoviário & 27 & 187 & 38 & 46 & 1742 & 1158 & 3850 & 450 & 540 & 48 & 320 & 64 \\
\hline 41 & Transporte aéreo & 1048 & 0 & 0 & 0 & 571 & 29 & 573 & 74 & 492 & 0 & 76 & 1 \\
\hline 42 & Transporte ferroviário & 309 & 0 & 0 & 0 & 168 & 1 & 19 & 25 & 2 & 0 & 177 & 0 \\
\hline 43 & Transporte aquaviário & 188 & 3 & 1 & 0 & 101 & 0 & 367 & 20 & 330 & 9 & 1062 & 34 \\
\hline 44 & Atividades aux. dos transp. & 48 & 42 & 9 & 8 & 4 & 103 & 2902 & 33 & 231 & 3 & 197 & 2 \\
\hline 45 & Comunicações & 79 & 78 & 19 & 10 & 13 & 9 & 7030 & 308 & 217 & 100 & 383 & 5 \\
\hline 46 & Instituições financeiras & 58 & 34 & 8 & 4 & 4 & 46 & 32 & 75 & 27 & 12 & 107 & 0 \\
\hline 47 & Serv. prest. às famílias & 317 & 11 & 2 & 1 & 245 & 4851 & 39722 & 743 & 1021 & 49 & 10451 & 65 \\
\hline 48 & Serv. prest. às empresas & 46 & 78 & 9 & 6 & 8 & 1617 & 33829 & 189 & 2232 & 281 & 1726 & 10 \\
\hline 49 & Aluguel de imóveis & 9 & 14 & 0 & 0 & 2 & 23 & 2498 & 21 & 15 & 14 & 98 & 3 \\
\hline 50 & Administração pública & 127 & 72 & 9 & 5 & 52 & 726 & 13033 & 532 & 1378 & 118 & 1581 & 13 \\
\hline 51 & Serv. priv. não mercantis & 0 & 0 & 0 & 0 & 0 & 0 & 0 & 0 & 0 & 0 & 0 & 0 \\
\hline
\end{tabular}


APÊNDICE 1 - Matriz insumo-produto inter-regional Mato Grosso x resto do Brasil / 1999.

\begin{tabular}{|c|c|c|c|c|c|c|c|c|c|c|c|c|c|c|}
\hline \multirow{2}{*}{\multicolumn{2}{|c|}{$\begin{array}{l}\text { resto do Brasil } \\
\text { Setores }\end{array}$}} & \multicolumn{13}{|c|}{ Mato Grosso } \\
\hline & & 1 & 2 & 3 & 4 & 5 & 6 & 7 & 8 & 9 & 10 & 11 & 12 & 13 \\
\hline 1 & Cana-de-açúcar & & & & & & & & & & & & & \\
\hline 2 & Soja & 0 & 4000 & 0 & 2 & 26 & 0 & 1 & 0 & 159 & 0 & 0 & 0 & 0 \\
\hline 3 & Milho & 24 & 15292 & 456 & 50 & 2126 & 359 & 27134 & 1214 & 12727 & 183 & 0 & 0 & 0 \\
\hline 4 & Fruticultura & 0 & 4656 & 159 & 531 & 13306 & 0 & 1 & 0 & 8502 & 0 & 0 & 0 & 0 \\
\hline 5 & Outras culturas & 8185 & 51858 & 3305 & 7033 & 127555 & 288 & 161211 & 1 & 96445 & 13855 & 4 & 71 & 247 \\
\hline 6 & Aves & 17 & 653 & 23 & 5 & 621 & 1021 & 1181 & 0 & 2039 & 56 & 0 & 0 & 0 \\
\hline 7 & Bovinos & 0 & 4017 & 55 & 8 & 435 & 7 & 73746 & 0 & 13738 & 152 & 0 & 0 & 0 \\
\hline 8 & Suínos & 0 & 0 & 0 & 0 & 0 & 0 & 0 & 46 & 0 & 0 & 0 & 0 & 0 \\
\hline 9 & Outros pecuária & 0 & 17204 & 83 & 65 & 826 & 0 & 6532 & 0 & 1917 & 0 & 0 & 0 & 0 \\
\hline 10 & Extrativismo vegetal & 0 & 32 & 0 & 0 & 3 & 0 & 3 & 0 & 1 & 132 & 0 & 0 & 0 \\
\hline 11 & Silvicultura & 0 & 1 & 0 & 0 & 0 & 0 & 0 & 0 & 0 & 0 & 0 & 0 & 0 \\
\hline 12 & Extrativismo animal & 0 & 0 & 0 & 0 & 0 & 0 & 0 & 0 & 0 & 0 & 0 & 0 & 0 \\
\hline 13 & Extrat. Mineral & 43 & 4036 & 29 & 26 & 345 & 1 & 361 & 0 & 161 & 1 & 0 & 11 & 3821 \\
\hline 14 & Siderurgia & 464 & 5100 & 330 & 269 & 3522 & 212 & 3347 & 191 & 1530 & 324 & 0 & 90 & 20055 \\
\hline 15 & Maq. e implem. agrícolas & 1 & 9 & 1 & 1 & 11 & 5 & 10 & 1 & 5 & 1 & 0 & 3 & 21 \\
\hline 16 & Outras maq. e equip. & 569 & 11113 & 890 & 227 & 1915 & 122 & 3235 & 10 & 1790 & 253 & 1 & 40 & 8322 \\
\hline 17 & Eletro-eletrônicos & 26 & 459 & 37 & 13 & 134 & 10 & 161 & 4 & 89 & 14 & 0 & 1 & 510 \\
\hline 18 & Peças e veículos & 20 & 320 & 26 & 10 & 112 & 22 & 127 & 4 & 70 & 11 & 0 & 177 & 349 \\
\hline 19 & Madeira e mobiliário & 6 & 438 & 9 & 15 & 210 & 20 & 171 & 5 & 43 & 24 & 0 & 19 & 38 \\
\hline 20 & cel., papel e gráfica & 93 & 612 & 49 & 78 & 1128 & 226 & 641 & 30 & 226 & 1 & 0 & 13 & 1107 \\
\hline 21 & Químicos diversos & 9263 & 155944 & 12565 & 5229 & 57028 & 3279 & 77521 & 596 & 28106 & 2236 & 1 & 13 & 7041 \\
\hline 22 & Âlcool & 65 & 998 & 80 & 32 & 344 & 15 & 527 & 4 & 186 & 19 & 0 & 3 & 33 \\
\hline 23 & Refino do petróleo & 11458 & 119014 & 12030 & 3579 & 33416 & 2048 & 46777 & 923 & 19593 & 4136 & 1 & 2925 & 12267 \\
\hline 24 & Adubos e fertilizantes & 23980 & 286502 & 25242 & 6595 & 60995 & 444 & 21811 & 0 & 34433 & 2318 & 1 & 1 & 5 \\
\hline 25 & Farmac. e veterinária & 291 & 4226 & 340 & 197 & 2362 & 729 & 21678 & 951 & 2164 & 183 & 0 & 0 & 130 \\
\hline 26 & Ind. têxtil e calçadista & 1 & 2283 & 182 & 492 & 7139 & 13 & 1949 & 3 & 1556 & 0 & 0 & 21 & 437 \\
\hline 27 & Indústria do café & 0 & 1 & 0 & 0 & 0 & 0 & 0 & 0 & 0 & 0 & 0 & 0 & 0 \\
\hline 28 & Benef. Prod. vegetais & 42 & 576 & 41 & 22 & 335 & 141 & 1943 & 177 & 266 & 31 & 0 & 0 & 18 \\
\hline 29 & Abate de outros animais & 0 & 93 & 1 & 0 & 5 & 0 & 39 & 0 & 10 & 0 & 0 & 0 & 1 \\
\hline 30 & Abate de bovinos & 0 & 93 & 1 & 0 & 5 & 0 & 40 & 0 & 11 & 0 & 0 & 0 & 1 \\
\hline 31 & Indústria de laticínios & 2 & 36 & 3 & 1 & 12 & 0 & 18 & 0 & 6 & 1 & 0 & 0 & 1 \\
\hline 32 & Fabricação de açúcar & 10 & 2 & 0 & 0 & 26 & 3 & 2 & 0 & 44 & 0 & 0 & 3 & 3 \\
\hline 33 & Fab. óleos vegetais & 32 & 863 & 34 & 16 & 189 & 479 & 4335 & 151 & 76 & 10 & 0 & 0 & 16 \\
\hline 34 & Rações & 642 & 2514 & 195 & 213 & 3406 & 17784 & 189877 & 24618 & 317 & 265 & 0 & 0 & 2 \\
\hline 35 & Outros prod. alimentares & 17 & 258 & 16 & 7 & 121 & 41 & 946 & 42 & 123 & 16 & 0 & 0 & 193 \\
\hline 36 & Indústrias diversas & 36 & 632 & 51 & 22 & 249 & 15 & 336 & 3 & 120 & 10 & 0 & 822 & 334 \\
\hline 37 & S.I.U.P. & 112 & 337 & 27 & 37 & 652 & 755 & 465 & 43 & 311 & 33 & 0 & 0 & 1240 \\
\hline 38 & Construção civil & 1 & 9 & 1 & 1 & 8 & 1 & 8 & 1 & 4 & 1 & 0 & 0 & 93 \\
\hline 39 & $\begin{array}{l}\text { Comércio } \\
\text { liti }\end{array}$ & 247 & 36561 & 200 & 53 & 1127 & 53 & 13800 & 69 & 661 & 601 & 0 & 102 & 129 \\
\hline 40 & Transporte rodoviário & 405 & 3239 & 259 & 0 & 3300 & 0 & 3406 & 214 & 1532 & 349 & 0 & 0 & 81 \\
\hline 41 & Transporte aéreo & 3 & 21 & 2 & 2 & 21 & 2 & 23 & 1 & 10 & 2 & 0 & 0 & 774 \\
\hline 42 & Transporte ferroviário & 76 & 1075 & 104 & 0 & 304 & 56 & 305 & 23 & 167 & 27 & 0 & 9 & 68 \\
\hline 43 & Transporte aquaviário & 51 & 997 & 65 & 41 & 292 & 28 & 291 & 17 & 177 & 33 & 0 & 6 & 0 \\
\hline 44 & Atividades aux. dos transp. & 0 & 1 & 0 & 0 & 1 & 1 & 23 & 0 & 3 & 0 & 0 & 0 & 164 \\
\hline 45 & Comunicaçōes & 14 & 115 & 9 & 9 & 117 & 8 & 121 & 8 & 54 & 12 & 0 & 53 & 300 \\
\hline 46 & Instituições financeiras & 156 & 1249 & 100 & 97 & 1273 & 89 & 1314 & 82 & 591 & 134 & 0 & 28 & 902 \\
\hline 47 & Serv. prest. às famílias & 3 & 136 & 11 & 22 & 333 & 20 & 617 & 5 & 139 & 5 & 0 & 0 & 114 \\
\hline 48 & Serv. prest. às empresas & 260 & 2085 & 167 & 161 & 2116 & 148 & 2182 & 137 & 982 & 223 & 0 & 46 & 1053 \\
\hline 49 & Aluguel de imóveis & 0 & 5 & 0 & 0 & 7 & 4 & 106 & 2 & 13 & 1 & 0 & 0 & 179 \\
\hline 50 & Administração pública & 1183 & 14599 & 1237 & 375 & 3845 & 117 & 3349 & 68 & 2355 & 192 & 0 & 39 & 363 \\
\hline 51 & Serv. priv. não mercantis & 0 & 0 & 0 & 0 & 0 & 0 & 0 & 0 & 0 & 0 & 0 & 0 & 0 \\
\hline
\end{tabular}


APÊNDICE 1 - Matriz insumo-produto inter-regional Mato Grosso x resto do Brasil / 1999.

\begin{tabular}{|c|c|c|c|c|c|c|c|c|c|c|c|c|c|c|}
\hline \multirow{2}{*}{\multicolumn{2}{|c|}{$\begin{array}{l}\text { resto do Brasil } \\
\text { Setores }\end{array}$}} & \multicolumn{13}{|c|}{ Mato Grosso } \\
\hline & & 14 & 15 & 16 & 17 & 18 & 19 & 20 & 21 & 22 & 23 & 24 & 25 & 26 \\
\hline 1 & Cana-de-açúcar & & & & & & & & & & & & & \\
\hline 2 & Soja & 0 & 0 & 0 & 0 & 0 & 0 & 0 & 0 & 0 & 0 & 0 & 0 & 0 \\
\hline 3 & Milho & 0 & 0 & 0 & 0 & 0 & 0 & 0 & 0 & 0 & 0 & 0 & 0 & 0 \\
\hline 4 & Fruticultura & 0 & 0 & 0 & 0 & 0 & 0 & 0 & 0 & 0 & 0 & 0 & 0 & 0 \\
\hline 5 & Outras culturas & 0 & 0 & 0 & 0 & 0 & 0 & 0 & 22 & 1 & 0 & 0 & 0 & 2 \\
\hline 6 & Aves & 0 & 0 & 0 & 0 & 0 & 0 & 0 & 0 & 0 & 0 & 0 & 0 & 0 \\
\hline 7 & Bovinos & 0 & 0 & 0 & 0 & 0 & 0 & 0 & 0 & 0 & 0 & 0 & 0 & 0 \\
\hline 8 & Suínos & 0 & 0 & 0 & 0 & 0 & 0 & 0 & 0 & 0 & 0 & 0 & 0 & 5 \\
\hline 9 & Outros pecuária & 0 & 0 & 0 & 0 & 0 & 0 & 0 & 8 & 0 & 0 & 0 & 1 & 6 \\
\hline 10 & Extrativismo vegetal & 57 & 0 & 0 & 0 & 0 & 1033 & 0 & 34 & 0 & 10 & 0 & 0 & 0 \\
\hline 11 & Silvicultura & 286 & 0 & 0 & 0 & 0 & 14730 & 0 & 0 & 0 & 0 & 0 & 0 & 0 \\
\hline 12 & Extrativismo animal & 0 & 0 & 0 & 0 & 0 & 0 & 0 & 0 & 0 & 0 & 0 & 0 & 0 \\
\hline 13 & Extrat. Mineral & 1452 & 24 & 1 & 0 & 0 & 4 & 1 & 47 & 9 & 19119 & 51 & 1 & 2 \\
\hline 14 & Siderurgia & 7545 & 871 & 22 & 4 & 12 & 7509 & 264 & 260 & 423 & 414 & 307 & 18 & 195 \\
\hline 15 & Maq. e implem. agrícolas & 10 & 2 & 0 & 0 & 0 & 1332 & 2 & 1 & 4466 & 1 & 0 & 0 & 1 \\
\hline 16 & Outras maq. e equip. & 3423 & 204 & 4 & 1 & 2 & 576 & 558 & 570 & 127 & 819 & 101 & 49 & 173 \\
\hline 17 & Eletro-eletrônicos & 350 & 137 & 18 & 2 & 1 & 226 & 30 & 51 & 475 & 40 & 11 & 3 & 15 \\
\hline 18 & Peças e veículos & 135 & 77 & 2 & 0 & 8 & 431 & 19 & 21 & 195 & 23 & 6 & 2 & 16 \\
\hline 19 & Madeira e mobiliário & 45 & 3 & 0 & 0 & 0 & 6794 & 2 & 9 & 12 & 1 & 2 & 1 & 23 \\
\hline 20 & cel., papel e gráfica & 2018 & 16 & 1 & 0 & 0 & 2825 & 2965 & 23 & 602 & 29 & 73 & 24 & 652 \\
\hline 21 & Químicos diversos & 4651 & 119 & 3 & 1 & 2 & 11464 & 1665 & 1660 & 7704 & 287 & 2066 & 208 & 3665 \\
\hline 22 & Alcool & 10 & 0 & 0 & 0 & 0 & 74 & 3 & 9 & 131 & 23 & 21 & 2 & 6 \\
\hline 23 & Refino do petróleo & 8133 & 60 & 2 & 1 & 1 & 11162 & 788 & 1568 & 4098 & 1411 & 1570 & 31 & 1306 \\
\hline 24 & Adubos e fertilizantes & 11 & 0 & 0 & 0 & 0 & 20 & 3 & 8 & 415 & 4 & 550 & 1 & 5 \\
\hline 25 & Farmac. e veterinária & 27 & 0 & 0 & 0 & 0 & 86 & 9 & 18 & 192 & 3 & 23 & 41 & 17 \\
\hline 26 & Ind. têxtil e calçadista & 113 & 11 & 0 & 0 & 0 & 1161 & 104 & 521 & 97 & 33 & 89 & 5 & 1022 \\
\hline 27 & Indústria do café & 0 & 0 & 0 & 0 & 0 & 0 & 0 & 0 & 0 & 0 & 0 & 0 & 0 \\
\hline 28 & Benef. Prod. vegetais & 3 & 0 & 0 & 0 & 0 & 12 & 5 & 5 & 21 & 0 & 4 & 2 & 2 \\
\hline 29 & Abate de outros animais & 0 & 0 & 0 & 0 & 0 & 1 & 0 & 1 & 1 & 0 & 0 & 1 & 139 \\
\hline 30 & Abate de bovinos & 0 & 0 & 0 & 0 & 0 & 1 & 0 & 0 & 0 & 0 & 0 & 1 & 0 \\
\hline 31 & Indústria de laticínios & 0 & 0 & 0 & 0 & 0 & 1 & 0 & 0 & 2 & 0 & 0 & 0 & 0 \\
\hline 32 & Fabricação de açúcar & 3 & 0 & 0 & 0 & 0 & 4 & 1 & 2 & 6650 & 1 & 0 & 1 & 0 \\
\hline 33 & Fab. óleos vegetais & 4 & 0 & 0 & 0 & 0 & 11 & 1 & 46 & 12 & 4 & 3 & 46 & 2 \\
\hline 34 & Rações & 1 & 0 & 0 & 0 & 0 & 1 & 0 & 0 & 3 & 0 & 1 & 0 & 1 \\
\hline 35 & Outros prod. alimentares & 11 & 0 & 0 & 0 & 0 & 176 & 2 & 3 & 87 & 1 & 3 & 1 & 2 \\
\hline 36 & Indústrias diversas & 49 & 2 & 0 & 0 & 0 & 162 & 25 & 12 & 436 & 7 & 6 & 2 & 20 \\
\hline 37 & S.I.U.P. & 361 & 8 & 0 & 0 & 0 & 1211 & 87 & 18 & 1498 & 22 & 9 & 1 & 33 \\
\hline 38 & Construção civil & 0 & 0 & 0 & 0 & 0 & 83 & 0 & 0 & 71 & 0 & 0 & 0 & 0 \\
\hline 39 & Comércio & 18 & 0 & 0 & 0 & 0 & 590 & 4 & 2 & 99 & 1 & 1 & 0 & 1 \\
\hline 40 & Transporte rodoviário & 1 & 0 & 0 & 0 & 0 & 862 & 0 & 0 & 536 & 0 & 0 & 0 & 0 \\
\hline 41 & Transporte aéreo & 56 & 0 & 0 & 0 & 0 & 14 & 0 & 0 & 2 & 0 & 0 & 0 & 0 \\
\hline 42 & Transporte ferroviário & 27 & 0 & 0 & 0 & 0 & 38 & 0 & 0 & 2 & 0 & 0 & 0 & 0 \\
\hline 43 & Transporte aquaviário & 0 & 0 & 0 & 0 & 0 & 0 & 0 & 0 & 0 & 0 & 0 & 0 & 0 \\
\hline 44 & Atividades aux. dos transp. & 0 & 0 & 0 & 0 & 0 & 157 & 0 & 0 & 93 & 0 & 0 & 0 & 0 \\
\hline 45 & Comunicaç̃̃es & 2 & 0 & 0 & 0 & 0 & 599 & 1 & 0 & 185 & 0 & 0 & 0 & 0 \\
\hline 46 & Instituiçōes financeiras & 208 & 0 & 0 & 0 & 0 & 210 & 0 & 0 & 391 & 0 & 0 & 0 & 9 \\
\hline 47 & Serv. prest. à famílias & 2 & 0 & 0 & 0 & 0 & 116 & 2 & 8 & 39 & 1 & 2 & 0 & 11 \\
\hline 48 & Serv. prest. às empresas & 1 & 0 & 0 & 0 & 0 & 393 & 0 & 0 & 163 & 0 & 0 & 0 & 0 \\
\hline 49 & Aluguel de imóveis & 72 & 0 & 0 & 0 & 0 & 223 & 0 & 0 & 25 & 0 & 0 & 0 & 0 \\
\hline 50 & Administração pública & 254 & 3 & 0 & 0 & 0 & 609 & 356 & 5 & 137 & 5 & 36 & 5 & 83 \\
\hline 51 & Serv. priv. não mercantis & 0 & 0 & 0 & 0 & 0 & 0 & 0 & 0 & 0 & 0 & 0 & 0 & 0 \\
\hline
\end{tabular}


APÊNDICE 1 - Matriz insumo-produto inter-regional Mato Grosso x resto do Brasil / 1999.

\begin{tabular}{|c|c|c|c|c|c|c|c|c|c|c|c|c|c|c|}
\hline \multirow{2}{*}{\multicolumn{2}{|c|}{$\begin{array}{l}\text { resto do Brasil } \\
\text { Setores }\end{array}$}} & \multicolumn{13}{|c|}{ Mato Grosso } \\
\hline & & 27 & 28 & 29 & 30 & 31 & 32 & 33 & 34 & 35 & 36 & 37 & 38 & 39 \\
\hline 1 & Cana-de-açúcar & & & & & & & & & & & & & \\
\hline 2 & Soja & 0 & 22 & 3 & 9 & 0 & 0 & 21289 & 1 & 77 & 0 & 0 & 0 & 0 \\
\hline 3 & Milho & 0 & 103 & 40 & 0 & 0 & 0 & 567 & 174 & 274 & 0 & 0 & 0 & 0 \\
\hline 4 & Fruticultura & 0 & 537 & 2 & 5 & 0 & 0 & 131 & 1 & 1707 & 0 & 0 & 0 & 0 \\
\hline 5 & Outras culturas & 264 & 3611 & 3144 & 2818 & 0 & 141 & 739 & 4 & 195 & 0 & 0 & 0 & 0 \\
\hline 6 & Aves & 0 & 0 & 54532 & 0 & 0 & 0 & 0 & 0 & 33 & 0 & 0 & 0 & 0 \\
\hline 7 & Bovinos & 0 & 4 & 0 & 12397 & 48 & 0 & 99 & 3 & 18 & 0 & 0 & 0 & 0 \\
\hline 8 & Suínos & 0 & 0 & 5236 & 0 & 0 & 0 & 96 & 0 & 1 & 0 & 0 & 0 & 0 \\
\hline 9 & Outros pecuária & 0 & 0 & 38 & 0 & 0 & 0 & 23756 & 141 & 130 & 6 & 13 & 0 & 0 \\
\hline 10 & Extrativismo vegetal & 0 & 1 & 0 & 0 & 0 & 0 & 0 & 0 & 0 & 0 & 0 & 7 & 13 \\
\hline 11 & Silvicultura & 0 & 0 & 0 & 0 & 0 & 0 & 0 & 0 & 0 & 0 & 0 & 5 & 0 \\
\hline 12 & Extrativismo animal & 0 & 0 & 0 & 0 & 0 & 0 & 0 & 0 & 0 & 0 & 0 & 0 & 0 \\
\hline 13 & Extrat. Mineral & 0 & 1 & 8 & 11 & 0 & 3 & 23 & 15 & 29 & 69 & 75 & 438 & 71 \\
\hline 14 & Siderurgia & 2 & 851 & 2444 & 1743 & 19 & 1836 & 21535 & 461 & 3084 & 1213 & 622 & 216696 & 5964 \\
\hline 15 & Maq. e implem. agrícolas & 0 & 3 & 10 & 7 & 0 & 2286 & 60 & 2 & 8 & 2 & 147 & 289 & 124 \\
\hline 16 & Outras maq. e equip. & 7 & 396 & 1377 & 980 & 7 & 3672 & 4304 & 223 & 928 & 228 & 9776 & 13526 & 12781 \\
\hline 17 & Eletro-eletrônicos & 1 & 27 & 92 & 66 & 1 & 346 & 313 & 15 & 65 & 160 & 4432 & 33426 & 1780 \\
\hline 18 & Peças e veículos & 0 & 24 & 85 & 60 & 1 & 199 & 437 & 15 & 64 & 18 & 655 & 2490 & 717 \\
\hline 19 & Madeira e mobiliário & 0 & 7 & 57 & 42 & 0 & 100 & 153 & 8 & 34 & 28 & 37 & 3605 & 6740 \\
\hline 20 & cel., papel e gráfica & 3 & 753 & 2572 & 1840 & 13 & 1839 & 8713 & 733 & 3190 & 252 & 1413 & 1179 & 94186 \\
\hline 21 & Químicos diversos & 15 & 653 & 3990 & 2925 & 37 & 2817 & 9407 & 894 & 4077 & 1224 & 1026 & 59239 & 32027 \\
\hline 22 & Ầlcool & 0 & 2 & 6 & 5 & 0 & 18 & 36 & 10 & 45 & 2 & 22 & 101 & 120341 \\
\hline 23 & Refino do petróleo & 3 & 902 & 2573 & 1837 & 17 & 2521 & 12748 & 604 & 2752 & 1007 & 9978 & 20630 & 970479 \\
\hline 24 & Adubos e fertilizantes & 0 & 2 & 2 & 1 & 0 & 6 & 18 & 1 & 6 & 4 & 0 & 32 & 49 \\
\hline 25 & Farmac. e veterinária & 0 & 11 & 148 & 109 & 0 & 32 & 216 & 131 & 624 & 5 & 51 & 39 & 92 \\
\hline 26 & Ind. têxtil e calçadista & 2 & 308 & 224 & 219 & 1 & 4791 & 15933 & 46 & 201 & 483 & 80 & 692 & 5537 \\
\hline 27 & Indústria do café & 97 & 3 & 1 & 3 & 0 & 0 & 70 & 5 & 22 & 0 & 0 & 0 & 16 \\
\hline 28 & Benef. Prod. vegetais & 0 & 168 & 650 & 497 & 2 & 4 & 15228 & 1428 & 11159 & 0 & 2 & 5 & 34 \\
\hline 29 & Abate de outros animais & 0 & 0 & 1163 & 0 & 0 & 0 & 2914 & 1 & 41 & 1 & 1 & 0 & 22 \\
\hline 30 & Abate de bovinos & 0 & 1 & 0 & 2392 & 0 & 0 & 1862 & 1 & 30 & 1 & 0 & 0 & 13 \\
\hline 31 & Indústria de laticínios & 0 & 3 & 2 & 15 & 22 & 0 & 70 & 13 & 175 & 0 & 1 & 1 & 21 \\
\hline 32 & Fabricação de açúcar & 0 & 29 & 2 & 2 & 1 & 1422 & 17 & 56 & 248 & 0 & 77 & 1 & 619 \\
\hline 33 & Fab. óleos vegetais & 0 & 26 & 12 & 9 & 1 & 4 & 14787 & 2 & 743 & 1 & 2 & 5 & 26 \\
\hline 34 & Rações & 0 & 0 & 2015 & 1563 & 0 & 1 & 25 & 93 & 1 & 0 & 1 & 1 & 14 \\
\hline 35 & Outros prod. alimentares & 0 & 10 & 9 & 10 & 0 & 46 & 529 & 2 & 591 & 3 & 2 & 3 & 1643 \\
\hline 36 & Indústrias diversas & 1 & 8 & 177 & 142 & 0 & 148 & 617 & 6 & 44 & 32 & 1501 & 3182 & 2260 \\
\hline 37 & S.I.U.P. & 0 & 65 & 605 & 473 & 1 & 491 & 1643 & 46 & 194 & 19 & 15168 & 154 & 16505 \\
\hline 38 & Construção civil & 0 & 0 & 86 & 63 & 0 & 110 & 117 & 0 & 0 & 0 & 336 & 0 & 1657 \\
\hline 39 & Comércio & 0 & 3 & 149 & 153 & 0 & 45 & 8643 & 2 & 12 & 4 & 354 & 662 & 5344 \\
\hline 40 & Transporte rodoviário & 0 & 0 & 587 & 995 & 0 & 0 & 3086 & 0 & 1 & 0 & 7 & 2 & 15137 \\
\hline 41 & Transporte aéreo & 0 & 0 & 3 & 6 & 0 & 20 & 240 & 0 & 1 & 0 & 12 & 100 & 4973 \\
\hline 42 & Transporte ferroviário & 0 & 0 & 10 & 7 & 0 & 3 & 57 & 0 & 59 & 0 & 36 & 111 & 1467 \\
\hline 43 & Transporte aquaviário & 0 & 0 & 23 & 0 & 0 & 0 & 0 & 0 & 0 & 0 & 24 & 31 & 874 \\
\hline 44 & Atividades aux. dos transp. & 0 & 0 & 183 & 173 & 0 & 78 & 580 & 0 & 39 & 0 & 28 & 355 & 3890 \\
\hline 45 & Comunicaç̃̃es & 0 & 0 & 418 & 298 & 0 & 150 & 839 & 0 & 1 & 2 & 333 & 696 & 24738 \\
\hline 46 & Instituições financeiras & 0 & 0 & 478 & 351 & 0 & 159 & 1796 & 0 & 135 & 0 & 1241 & 830 & 16321 \\
\hline 47 & Serv. prest. à famílias & 0 & 11 & 76 & 58 & 0 & 241 & 163 & 1 & 3 & 6 & 237 & 8 & 7424 \\
\hline 48 & Serv. prest. às empresas & 0 & 0 & 533 & 391 & 0 & 318 & 971 & 0 & 1 & 0 & 904 & 2550 & 46680 \\
\hline 49 & Aluguel de imóveis & 0 & 0 & 113 & 83 & 0 & 30 & 190 & 0 & 75 & 0 & 569 & 264 & 25837 \\
\hline 50 & Administração pública & 0 & 111 & 410 & 297 & 2 & 286 & 1742 & 98 & 442 & 32 & 370 & 679 & 18683 \\
\hline 51 & Serv. priv. não mercantis & 0 & 0 & 0 & 0 & 0 & 0 & 0 & 0 & 0 & 0 & 0 & 0 & 0 \\
\hline
\end{tabular}


APÊNDICE 1 - Matriz insumo-produto inter-regional Mato Grosso x resto do Brasil / 1999.

\begin{tabular}{|c|c|c|c|c|c|c|c|c|c|c|c|c|c|}
\hline \multirow{2}{*}{\multicolumn{2}{|c|}{$\begin{array}{l}\text { resto do Brasil } \\
\text { Setores } \\
\end{array}$}} & \multicolumn{12}{|c|}{ Mato Grosso } \\
\hline & & 40 & 41 & 42 & 43 & 44 & 45 & 46 & 47 & 48 & 49 & 50 & 51 \\
\hline 1 & Cana-de-açúcar & & & & & & & & & & & & \\
\hline 2 & Soja & 0 & 0 & 0 & 0 & 0 & 0 & 0 & 36 & 0 & 0 & 18 & 1 \\
\hline 3 & Milho & 0 & 0 & 0 & 0 & 0 & 0 & 0 & 39 & 0 & 0 & 0 & 0 \\
\hline 4 & Fruticultura & 0 & 0 & 0 & 0 & 0 & 0 & 0 & 3831 & 0 & 0 & 3255 & 56 \\
\hline 5 & Outras culturas & 0 & 0 & 0 & 0 & 0 & 0 & 0 & 9311 & 0 & 0 & 7723 & 119 \\
\hline 6 & Aves & 0 & 0 & 0 & 0 & 0 & 0 & 0 & 275 & 0 & 0 & 29 & 5 \\
\hline 7 & Bovinos & 0 & 0 & 0 & 0 & 0 & 0 & 0 & 1495 & 0 & 0 & 40 & 18 \\
\hline 8 & Suínos & 0 & 0 & 0 & 0 & 0 & 0 & 0 & 18 & 0 & 0 & 4 & 0 \\
\hline 9 & Outros pecuária & 0 & 0 & 0 & 0 & 0 & 0 & 0 & 183 & 0 & 0 & 71 & 2 \\
\hline 10 & Extrativismo vegetal & 1 & 0 & 0 & 0 & 0 & 0 & 0 & 3 & 0 & 0 & 1 & 0 \\
\hline 11 & Silvicultura & 0 & 0 & 0 & 0 & 0 & 0 & 0 & 0 & 0 & 0 & 0 & 0 \\
\hline 12 & Extrativismo animal & 0 & 0 & 0 & 0 & 0 & 0 & 0 & 240 & 0 & 0 & 0 & 0 \\
\hline 13 & Extrat. Mineral & 7 & 2 & 0 & 0 & 0 & 3 & 2 & 24 & 27 & 0 & 69 & 5 \\
\hline 14 & Siderurgia & 754 & 49 & 430 & 16 & 423 & 2759 & 5 & 11104 & 234 & 14 & 3528 & 182 \\
\hline 15 & Maq. e implem. agrícolas & 21 & 2 & 2 & 0 & 3 & 14 & 2 & 64 & 10 & 1 & 45 & 2 \\
\hline 16 & Outras maq. e equip. & 1032 & 109 & 269 & 17 & 265 & 2202 & 29 & 2262 & 1207 & 371 & 2989 & 30 \\
\hline 17 & Eletro-eletrônicos & 167 & 17 & 19 & 3 & 51 & 7568 & 0 & 4081 & 487 & 101 & 2750 & 18 \\
\hline 18 & Pecas e veículos & 22958 & 2734 & 926 & 333 & 2314 & 787 & 5 & 36937 & 39 & 13 & 7794 & 4 \\
\hline 19 & Madeira e mobiliário & 500 & 8 & 3 & 1 & 76 & 22 & 4 & 2842 & 44 & 2 & 584 & 10 \\
\hline 20 & cel., papel e gráfica & 2120 & 157 & 19 & 11 & 249 & 1889 & 302 & 5533 & 16700 & 17 & 35684 & 220 \\
\hline 21 & Químicos diversos & 33824 & 1361 & 408 & 201 & 1277 & 1798 & 2 & 38979 & 133 & 301 & 11208 & 191 \\
\hline 22 & Âlcool & 64 & 2 & 3 & 1 & 7 & 87 & 0 & 98 & 3 & 0 & 76 & 0 \\
\hline 23 & Refino do petróleo & 128007 & 12349 & 1127 & 2017 & 4644 & 118 & 12 & 5667 & 1590 & 8 & 6427 & 261 \\
\hline 24 & Adubos e fertilizantes & 4 & 0 & 1 & 0 & 1 & 0 & 0 & 21 & 1 & 0 & 17 & 0 \\
\hline 25 & Farmac. e veterinária & 1 & 4 & 0 & 0 & 3 & 2 & 1 & 13116 & 5 & 0 & 10356 & 1 \\
\hline 26 & Ind. têxtil e calçadista & 3235 & 234 & 165 & 45 & 481 & 379 & 4 & 20955 & 57 & 2 & 4248 & 11 \\
\hline 27 & Indústria do café́ & 0 & 0 & 0 & 0 & 0 & 0 & 0 & 6800 & 0 & 0 & 594 & 139 \\
\hline 28 & Benef. Prod. vegetais & 0 & 1 & 0 & 0 & 2 & 1 & 0 & 9136 & 1 & 0 & 1672 & 90 \\
\hline 29 & Abate de outros animais & 0 & 0 & 0 & 0 & 1 & 0 & 0 & 1005 & 0 & 0 & 178 & 28 \\
\hline 30 & Abate de bovinos & 0 & 0 & 0 & 0 & 1 & 0 & 0 & 612 & 0 & 0 & 117 & 17 \\
\hline 31 & Indústria de laticínios & 0 & 0 & 0 & 0 & 0 & 0 & 0 & 4187 & 0 & 0 & 3833 & 85 \\
\hline 32 & Fabricação de açúcar & 1 & 0 & 0 & 0 & 0 & 2 & 1 & 645 & 2 & 1 & 30 & 12 \\
\hline 33 & Fab. óleos vegetais & 1 & 1 & 0 & 0 & 1 & 0 & 0 & 499 & 0 & 0 & 53 & 9 \\
\hline 34 & Rações & 0 & 0 & 0 & 0 & 0 & 0 & 0 & 4 & 0 & 0 & 4 & 0 \\
\hline 35 & Outros prod. alimentares & 1 & 56 & 0 & 0 & 181 & 2 & 0 & 48817 & 1 & 0 & 1417 & 377 \\
\hline 36 & Indústrias diversas & 616 & 10 & 4 & 2 & 11 & 204 & 158 & 1364 & 1885 & 12 & 4445 & 376 \\
\hline 37 & S.I.U.P. & 221 & 12 & 13 & 2 & 56 & 121 & 131 & 2209 & 232 & 95 & 5321 & 54 \\
\hline 38 & Construção civil & 446 & 0 & 0 & 0 & 0 & 0 & 0 & 633 & 0 & 0 & 1486 & 28 \\
\hline 39 & Comércio & 898 & 64 & 19 & 11 & 50 & 78 & 19 & 364 & 346 & 3 & 3941 & 56 \\
\hline 40 & Transporte rodoviário & 7 & 1 & 0 & 0 & 1 & 4 & 0 & 67 & 3 & 0 & 298 & 1 \\
\hline 41 & Transporte aéreo & 1381 & 0 & 0 & 0 & 150 & 10 & 0 & 252 & 137 & 0 & 95 & 1 \\
\hline 42 & Transporte ferroviário & 408 & 0 & 0 & 0 & 44 & 0 & 0 & 75 & 1 & 0 & 209 & 0 \\
\hline 43 & Transporte aquaviário & 243 & 0 & 0 & 0 & 26 & 0 & 0 & 46 & 91 & 0 & 1123 & 15 \\
\hline 44 & Atividades aux. dos transp. & 1077 & 0 & 0 & 0 & 0 & 26 & 0 & 210 & 242 & 0 & 585 & 5 \\
\hline 45 & Comunicações & 1494 & 0 & 0 & 0 & 0 & 11 & 10 & 1896 & 114 & 1 & 2631 & 69 \\
\hline 46 & Instituições financeiras & 1934 & 179 & 45 & 24 & 121 & 642 & 0 & 885 & 473 & 0 & 2292 & 1 \\
\hline 47 & Serv. prest. às famílias & 471 & 9 & 2 & 1 & 15 & 0 & 0 & 563 & 0 & 0 & 9135 & 0 \\
\hline 48 & Serv. prest. às empresas & 1944 & 0 & 0 & 0 & 0 & 135 & 0 & 2180 & 3 & 0 & 18464 & 66 \\
\hline 49 & Aluguel de imóveis & 361 & 40 & 1 & 1 & 67 & 509 & 0 & 540 & 422 & 0 & 1914 & 126 \\
\hline 50 & Administração pública & 817 & 66 & 13 & 5 & 57 & 267 & 41 & 2052 & 2062 & 2 & 7876 & 51 \\
\hline 51 & Serv. priv. não mercantis & 0 & 0 & 0 & 0 & 0 & 0 & 0 & 0 & 0 & 0 & 0 & 0 \\
\hline
\end{tabular}


APÊNDICE 1 - Matriz insumo-produto inter-regional Mato Grosso x resto do Brasil / 1999.

\begin{tabular}{|c|c|c|c|c|c|c|c|c|c|c|c|c|c|c|}
\hline \multirow{2}{*}{\multicolumn{2}{|c|}{$\begin{array}{l}\text { resto do Brasil } \\
\text { Setores }\end{array}$}} & \multicolumn{13}{|c|}{ resto do Brasil } \\
\hline & & 1 & 2 & 3 & 4 & 5 & 6 & 7 & 8 & 9 & 10 & 11 & 12 & 13 \\
\hline 1 & Cana-de-açúcar & & & & & & & & & & & & & \\
\hline 2 & Soja & 3 & 214734 & 7 & 953 & 7229 & 2 & 14 & 0 & 55835 & 0 & 0 & 0 & 5 \\
\hline 3 & Milho & 2066 & 50048 & 254933 & 33466 & 249394 & 327053 & 343955 & 624330 & 839302 & 2186 & 2293 & 0 & 4 \\
\hline 4 & Fruticultura & 3 & 15237 & 12540 & 74322 & 516058 & 2 & 12 & $\begin{array}{c}02+300 \\
0\end{array}$ & 302312 & $\begin{array}{c}2100 \\
0\end{array}$ & 0 & 0 & 5 \\
\hline 5 & Outras culturas & 208219 & 170025 & 140777 & 386978 & 2897867 & 29593 & 1628276 & 29 & 2684535 & 113080 & 118828 & 7543 & 11321 \\
\hline 6 & Aves & 610 & & 1770 & 3312 & 22978 & 928307 & 12477 & 0 & 68627 & 515 & 543 & 0 & 0 \\
\hline $\begin{array}{l}0 \\
7\end{array}$ & $\begin{array}{l}\text { Aves } \\
\text { Bovinos }\end{array}$ & $\begin{array}{c}010 \\
0\end{array}$ & 13145 & 10885 & 5090 & 27318 & 6423 & 1529893 & 0 & 647822 & 1586 & $\begin{array}{c}343 \\
1660\end{array}$ & 0 & 0 \\
\hline 8 & Suínos & 0 & 0 & 0 & 0 & 0 & 0 & 0 & 24740 & 0 & 0 & 0 & 0 & 0 \\
\hline 9 & Outros pecuária & 0 & 61496 & 49542 & 46566 & 299643 & 0 & 112359 & 0 & 767522 & 0 & 0 & 0 & 1 \\
\hline 10 & Extrativismo vegetal & 102 & 130 & 101 & 126 & 847 & 14 & 411 & 2 & 417 & 1463 & 1557 & 0 & 266 \\
\hline 11 & Silvicultura & 1 & 2 & 2 & 10 & 74 & 15 & 5 & 2 & 12 & 1 & 1 & 0 & 44 \\
\hline 12 & Extrativismo animal & 0 & 0 & 0 & 0 & 0 & 0 & 0 & 0 & 0 & 0 & 0 & 0 & 0 \\
\hline 13 & Extrat. Mineral & 13122 & 16670 & 12988 & 15185 & 101176 & 131 & 52958 & 6 & 52733 & 5 & 4280 & 655 & 188445 \\
\hline 14 & Siderurgia & 13626 & 17786 & 14580 & 14984 & 97741 & 12040 & 47021 & 5972 & 47206 & 2626 & 4194 & 3932 & 1284302 \\
\hline 15 & Maq. e implem. agrícolas & 61 & 50 & 42 & 55 & 367 & 815 & 154 & 35 & 187 & 10 & 11 & 160 & 2315 \\
\hline 16 & Outras maq. e equip. & 13029 & 36651 & 30370 & 9536 & 41296 & 13953 & 33384 & 490 & 40741 & 2087 & 2196 & 2221 & 620746 \\
\hline 17 & Eletro-eletrônicos & 693 & 1713 & 1419 & 611 & 3167 & 759 & 1794 & 140 & 2223 & 119 & 125 & 75 & 33711 \\
\hline 18 & Peças e veículos & 524 & 1090 & 902 & 480 & 2695 & 2852 & 1493 & 169 & 1771 & 97 & 102 & 6829 & 27098 \\
\hline 19 & Madeira e mobiliário & 771 & 1546 & 1247 & 5464 & 39731 & 8233 & 2805 & 1317 & 6998 & 567 & 581 & 1098 & 17296 \\
\hline 20 & cel., papel e gráfica & 2066 & 2031 & 1683 & 3323 & 23178 & 12940 & 6479 & 943 & 5034 & 9 & 9 & 588 & 152315 \\
\hline 21 & Químicos diversos & 205392 & 510688 & 425238 & 212666 & 1169889 & 186003 & 783302 & 19285 & 622879 & 18057 & 18987 & 675 & 383746 \\
\hline 22 & Álcool & 1467 & 3303 & 2733 & 1327 & 7219 & 897 & 5385 & 116 & 4207 & 156 & 168 & 114 & 1873 \\
\hline 23 & Refino do petróleo & 243391 & 369743 & 388683 & 138597 & 652521 & 103604 & 460117 & 26292 & 415052 & 32766 & 34512 & 111509 & 609917 \\
\hline 24 & Adubos e fertilizantes & 531944 & 937807 & 854530 & 280199 & 1250479 & 26182 & 219552 & 18 & 762390 & 18686 & 19699 & 36 & 220 \\
\hline 25 & Farmac. e veterinária & 6504 & 13910 & 11549 & 8027 & 48605 & 41050 & 218438 & 29746 & 48048 & 1480 & 1556 & 8 & 7370 \\
\hline 26 & Ind. têxtil e calçadista & 138 & 7556 & 6260 & 20070 & 147021 & 4453 & 21892 & 732 & 34579 & 16 & 17 & 1181 & 22076 \\
\hline $\begin{array}{l}20 \\
27\end{array}$ & Indústria do caféséstá & 21 & 38 & ${ }_{31}^{0200}$ & 14 & $\begin{array}{c}14 / 121 \\
74\end{array}$ & $\begin{array}{l}4453 \\
25\end{array}$ & 32 & 3 & $\begin{array}{c}5479 \\
44\end{array}$ & $\begin{array}{c}10 \\
2\end{array}$ & 2 & $\begin{array}{c}1181 \\
3\end{array}$ & 57 \\
\hline 28 & Benef. Prod. vegeta & 1257 & 2061 & 1704 & 1650 & 10481 & 17557 & 24768 & 7144 & 9582 & 290 & 303 & 18 & 1070 \\
\hline 29 & Abate de outros animais & 18 & 360 & 291 & 260 & 1657 & 39 & 671 & 12 & 4116 & 1 & 1 & 3 & 142 \\
\hline 30 & Abate de bovinos & 10 & 350 & 282 & 257 & 1648 & 22 & 669 & 7 & 4156 & 1 & 1 & 2 & 80 \\
\hline 31 & Indústria de laticínios & 110 & 229 & 189 & 87 & 465 & 107 & 264 & 13 & 269 & 9 & 9 & 11 & 141 \\
\hline 32 & Fabricação de açúcar & 458 & 47 & 39 & 171 & 1237 & 463 & 71 & 14 & 1749 & 4 & 4 & 1856 & 538 \\
\hline 33 & Fab. óleos vegetais & 3563 & 3176 & 2609 & 2981 & 19704 & 417233 & 305831 & 75664 & 1769 & 480 & 497 & 8 & 938 \\
\hline 34 & Rações & 14246 & 8254 & 6836 & 10288 & 70137 & 1187109 & 1910930 & 787859 & 7783 & 2139 & 2253 & 2 & 148 \\
\hline 35 & Outros prod. alimentares & 492 & 937 & 772 & 719 & 4538 & 5124 & 11069 & 1758 & 4858 & 136 & 143 & 8 & 9790 \\
\hline 36 & Indústrias diversas & 816 & 2088 & 1728 & 917 & 5146 & 835 & 3407 & 107 & 2679 & 81 & 85 & 46947 & 42364 \\
\hline 37 & S.I.U.P. & 18105 & 8053 & 6651 & 13921 & 97537 & 387094 & 34191 & 9905 & 50317 & 1963 & 2051 & 39 & 752568 \\
\hline 38 & Construução civil & 187 & 232 & 193 & 204 & 1338 & 262 & 669 & 128 & 676 & 54 & 57 & 55 & 122904 \\
\hline 39 & Comércio & 323311 & 640995 & 525672 & 211082 & 1053088 & 319633 & 527057 & 90240 & 631839 & 26677 & 27447 & 67972 & 622278 \\
\hline 40 & Transporte rodoviário & 72378 & 86048 & 71115 & 82878 & 549017 & 103596 & 278311 & 54183 & 275256 & 22825 & 23728 & 22463 & 123425 \\
\hline 41 & Transporte aéreo & 461 & 547 & 452 & 526 & 3491 & 675 & 1852 & 346 & 1770 & 145 & 152 & 143 & 279062 \\
\hline 42 & Transporte ferroviário & 13478 & 28332 & 28342 & 0 & 50152 & 24752 & 24706 & 5851 & 29725 & 1746 & 1829 & 2846 & 40277 \\
\hline 43 & Transporte aquaviário & 9039 & 26281 & 17627 & 13535 & 48196 & 12479 & 23570 & 4289 & 31613 & 2159 & 2261 & 1779 & 25986 \\
\hline 44 & Atividades aux. dos transp. & 5 & 28 & 23 & 34 & 233 & 336 & 1855 & 40 & 548 & 9 & 9 & 0 & 67669 \\
\hline 45 & $\begin{array}{l}\text { Comunicações } \\
\text { S }\end{array}$ & 2574 & 3036 & 2516 & 2924 & 19376 & 3683 & 9815 & 1912 & 9713 & 806 & 846 & 3663 & 204842 \\
\hline 46 & Instituições financeiras & 28085 & 33137 & 27456 & 31917 & 211475 & 40209 & 107227 & 20873 & 106035 & 8798 & 9258 & 8656 & 719863 \\
\hline 47 & Serv. prest. às famílias & 548 & 1583 & 1309 & 2065 & 14150 & 9080 & 48304 & 1213 & 16350 & 321 & 334 & 103 & 70769 \\
\hline 48 & Serv. prest. às empresas & 46457 & 54951 & 45532 & 52740 & 349251 & 66427 & 176884 & 34433 & 175139 & 14513 & 15200 & 14295 & 1027287 \\
\hline 49 & $\begin{array}{l}\text { Aluguel de imóveis } \\
\text { a }\end{array}$ & 25 & 129 & 107 & 159 & 1082 & 1572 & 8606 & 450 & 2285 & 42 & 44 & 0 & 93298 \\
\hline 50 & Administração pública & 32657 & 55382 & 49187 & 24665 & 135561 & 15770 & 58942 & 6827 & 96122 & 3552 & 3726 & 4002 & 182197 \\
\hline 51 & Serv. priv. não mercantis & 0 & 0 & 0 & 0 & 0 & 0 & 0 & 0 & 0 & 0 & 0 & 0 & 0 \\
\hline
\end{tabular}


APÊNDICE 1 - Matriz insumo-produto inter-regional Mato Grosso x resto do Brasil / 1999.

\begin{tabular}{|c|c|c|c|c|c|c|c|c|c|c|c|c|c|c|}
\hline \multirow{2}{*}{\multicolumn{2}{|c|}{$\begin{array}{l}\text { resto do Brasil } \\
\text { Setores }\end{array}$}} & \multirow{2}{*}{\multicolumn{13}{|c|}{ resto do Brasil }} \\
\hline & & 14 & & & 17 & 18 & 19 & 20 & 21 & 22 & 23 & 24 & 25 & \\
\hline 1 & Cana-de-açúcar & & & & & & & & & & & & & \\
\hline 2 & Soja & 9 & 0 & 1 & 1 & 1 & 2 & 816 & 360 & 8 & 6 & 108 & 228 & 116 \\
\hline 3 & Milho & 7 & 0 & 1 & 1 & 1 & 2 & 4 & 30 & 0 & 4 & 3 & 45 & 3 \\
\hline 4 & Fruticultura & 8 & 0 & 0 & 1 & 1 & 2 & 506 & 227 & 5 & 5 & 68 & 191 & 73 \\
\hline 5 & Outras culturas & $\begin{array}{l}0 \\
29\end{array}$ & 0 & 2 & 3 & 3 & 8 & 2699 & 211394 & 27 & 18 & 356 & 5590 & 977711 \\
\hline 6 & Aves & 0 & 0 & 0 & 0 & 0 & 0 & 0 & 0 & 0 & 0 & 0 & 0 & 0 \\
\hline 7 & Bovinos & 1 & 0 & 1 & 0 & 1 & 0 & 1 & 1603 & 0 & 0 & 0 & 5278 & 1 \\
\hline 8 & $\begin{array}{l}\text { Dovinos } \\
\text { Suínos }\end{array}$ & 0 & 0 & 0 & 0 & 0 & 0 & 0 & $\begin{array}{l}1003 \\
304\end{array}$ & 0 & 0 & 0 & 711 & $\begin{array}{c}1 \\
13156\end{array}$ \\
\hline $\begin{array}{l}8 \\
9\end{array}$ & $\begin{array}{l}\text { Sunosos } \\
\text { Outros pecuária }\end{array}$ & 3 & 0 & 1 & 1 & 1 & 1 & 1 & 77507 & 0 & 1 & 0 & 19839 & $\begin{array}{l}13150 \\
21570\end{array}$ \\
\hline 10 & Extrativismo vegetal & 512200 & 6 & 81 & 713 & 309 & 1084780 & 575 & 312089 & 0 & 6835 & 277 & 700 & 91 \\
\hline 11 & $\begin{array}{l}\text { Silvicultura } \\
\text { late }\end{array}$ & 583689 & 8 & $\begin{array}{l}91 \\
91\end{array}$ & 424 & 310 & 555543 & 642249 & 116 & 0 & 8 & 0 & 2 & 72 \\
\hline $\begin{array}{l}11 \\
12\end{array}$ & $\begin{array}{l}\text { Silvilutitura } \\
\text { Extrativismo animal }\end{array}$ & $\begin{array}{c}583689 \\
0\end{array}$ & $\begin{array}{l}8 \\
0\end{array}$ & $\begin{array}{c}91 \\
0\end{array}$ & $\begin{array}{c}424 \\
0\end{array}$ & $\begin{array}{c}310 \\
0\end{array}$ & $\begin{array}{c}535343 \\
0\end{array}$ & $\begin{array}{c}64249 \\
0\end{array}$ & $\begin{array}{c}116 \\
0\end{array}$ & 0 & $\begin{array}{l}8 \\
0\end{array}$ & 0 & 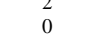 & 0 \\
\hline $\begin{array}{l}12 \\
13\end{array}$ & $\begin{array}{l}\text { Extrattvismo anmmal } \\
\text { Extrat. Mineral }\end{array}$ & $\begin{array}{c}0 \\
5071629\end{array}$ & $\begin{array}{c}0 \\
8208\end{array}$ & $\begin{array}{c}0 \\
114164\end{array}$ & $\begin{array}{c}0 \\
83795\end{array}$ & $\begin{array}{c}0 \\
94713\end{array}$ & $\begin{array}{c}0 \\
365\end{array}$ & $\begin{array}{c}0 \\
45556\end{array}$ & $\begin{array}{c}0 \\
369384\end{array}$ & $\begin{array}{c}0 \\
337\end{array}$ & $\begin{array}{c}0 \\
13198233\end{array}$ & $\begin{array}{c}0 \\
50350\end{array}$ & $\begin{array}{c}0 \\
24980\end{array}$ & $\begin{array}{c}0 \\
4091\end{array}$ \\
\hline 14 & Siderurgia & 28797670 & $\begin{array}{r}8208 \\
288986\end{array}$ & 4019615 & 4044679 & 6299116 & 468280 & 270717 & 902801 & 13304 & 651310 & 117281 & 352204 & 157814 \\
\hline 15 & Maq. e implem. agrícolas & $\begin{array}{l}17824 \\
1784\end{array}$ & $\begin{array}{c}2000000 \\
498\end{array}$ & 6925 & 6103 & 13616 & 27136 & 41989 & 3383 & 139003 & 2903 & 247 & 582 & 1924 \\
\hline 16 & Outras maq. e equip. & $\begin{array}{c}1704329 \\
17042\end{array}$ & $\begin{array}{c}490 \\
50569\end{array}$ & 703703 & 858540 & 1250543 & 54774 & 365408 & 495374 & 10179 & 592964 & 27608 & 75726 & 284539 \\
\hline 17 & Eletro-eletrônicos & 187344 & 33006 & 459303 & 2395144 & 208937 & 9772 & 22245 & $\begin{array}{l}495314 \\
44205\end{array}$ & 14854 & 29660 & 2973 & 5424 & 18704 \\
\hline 18 & $\begin{array}{l}\text { Peças e veículos } \\
\text { Pes }\end{array}$ & 131712 & 18999 & 264377 & $\begin{array}{c}253144 \\
67129\end{array}$ & 6208878 & 18612 & 17912 & 33722 & $\begin{array}{l}14864 \\
7465\end{array}$ & 23504 & 1875 & $\begin{array}{l}5424 \\
4629\end{array}$ & 15043 \\
\hline 19 & Madeira e mobiliário & 168163 & 4202 & 58614 & 226353 & 192690 & 2063469 & 193150 & 66138 & 631 & 6500 & 823 & 3863 & 43066 \\
\hline 20 & cel., papel e gráfica & 783140 & 10159 & 141282 & 337710 & 210289 & 112452 & 7053101 & 389489 & 18703 & 324323 & 46997 & 522413 & 377867 \\
\hline 21 & Químicos diversos & 2454141 & 38522 & 535966 & 1012191 & 1808397 & 832839 & 1593963 & 6352667 & 239291 & 1555834 & 773596 & 1442615 & 1445862 \\
\hline 22 & Álcool & 10421 & 131 & 1782 & 2404 & 4705 & 3187 & 6856 & 76395 & 49780 & 235483 & 8896 & 54376 & 3132 \\
\hline 23 & Refino do petróleo & 2113696 & 16951 & 236393 & 537319 & 467637 & 388837 & 687119 & 7505872 & 122399 & 15593271 & 644798 & 653585 & 1736144 \\
\hline 24 & Adubos e fertilizantes & 9347 & 55 & 747 & 2165 & $\begin{array}{l}407587 \\
1587\end{array}$ & $\begin{array}{l}500071 \\
887\end{array}$ & 2939 & 30457 & 12908 & 40645 & 2219467 & 16921 & 6094 \\
\hline 25 & Farmac. e veterinária & 22285 & 103 & 1438 & 1949 & 1989 & 3670 & 12078 & 118699 & 6111 & 20481 & 9704 & 884052 & 6744 \\
\hline 26 & Ind. têxtil e calcadista & 44760 & 3272 & 45545 & 26221 & 152968 & 182426 & 62589 & 401083 & 3176 & 48345 & 26427 & 15777 & 12144138 \\
\hline 27 & Indústria do café & 277 & 7 & 101 & 131 & 163 & 88 & 462 & 264 & 13 & 118 & 52 & 537 & 218 \\
\hline 28 & Benef. Prod. vegetais & 3418 & 36 & 500 & 665 & 872 & 743 & 47194 & 41265 & 741 & 2886 & 6906 & 50380 & 8439 \\
\hline $\begin{array}{l}28 \\
29\end{array}$ & $\begin{array}{l}\text { d. vegetais } \\
\text { utros animais }\end{array}$ & $\begin{array}{l}3418 \\
455\end{array}$ & $\begin{array}{l}36 \\
13\end{array}$ & $\begin{array}{l}500 \\
175\end{array}$ & $\begin{array}{l}605 \\
188\end{array}$ & $\begin{array}{l}812 \\
210\end{array}$ & $\begin{array}{l}743 \\
144\end{array}$ & ${ }_{292}^{4 / 194}$ & $\begin{array}{l}41263 \\
9181\end{array}$ & $\begin{array}{l}741 \\
31\end{array}$ & $\begin{array}{c}2880 \\
143\end{array}$ & $\begin{array}{c}6900 \\
34\end{array}$ & $\begin{array}{l}50301 \\
20101\end{array}$ & $\begin{array}{c}8359 \\
381505\end{array}$ \\
\hline 30 & Abate & 261 & 8 & 108 & 108 & 135 & 106 & 173 & 62 & 18 & 81 & 23 & 14038 & 1377 \\
\hline $\begin{array}{l}30 \\
31\end{array}$ & $\begin{array}{l}\text { Abate de bovvnoss } \\
\text { Indústria de latić́nios }\end{array}$ & ${ }_{742}^{261}$ & $\begin{array}{c}8 \\
17\end{array}$ & 230 & 317 & $\begin{array}{l}135 \\
476\end{array}$ & $\begin{array}{l}106 \\
236\end{array}$ & $\begin{array}{l}113 \\
696\end{array}$ & $\begin{array}{l}621 \\
3925\end{array}$ & $\begin{array}{l}18 \\
80\end{array}$ & $\begin{array}{r}81 \\
372\end{array}$ & $\begin{array}{l}23 \\
119\end{array}$ & $\begin{array}{l}140198 \\
10190\end{array}$ & 501 \\
\hline $\begin{array}{l}31 \\
32\end{array}$ & $\begin{array}{l}\text { Inusustrala de laticinios } \\
\text { Fabricacão de acúcar }\end{array}$ & $\begin{array}{r}142 \\
4412\end{array}$ & 45 & $\begin{array}{l}230 \\
626\end{array}$ & $\begin{array}{l}311 \\
399\end{array}$ & $\begin{array}{l}4 / 6 \\
716\end{array}$ & $\begin{array}{l}236 \\
506\end{array}$ & $\begin{array}{l}696 \\
1409\end{array}$ & $\begin{array}{l}3925 \\
16965\end{array}$ & $\begin{array}{c}80 \\
475552\end{array}$ & $\begin{array}{l}3 / 2 \\
1755\end{array}$ & $\begin{array}{l}119 \\
70\end{array}$ & $\begin{array}{l}10190 \\
18298\end{array}$ & $\begin{array}{l}501 \\
958\end{array}$ \\
\hline 33 & Fab. óleos vegetais & 3367 & 24 & 327 & 467 & 54 & 57 & 1971 & 465753 & 392 & 37948 & 1298 & 1001742 & 6005 \\
\hline 34 & sens & 777 & 7 & 99 & 139 & 14 & 1 & 41 & 1269 & 10 & 531 & 262 & 4987 & 1988 \\
\hline 35 & d. alimentares & 23443 & 647 & 8993 & 6390 & $\begin{array}{l}14 \\
74\end{array}$ & 71 & $\begin{array}{l}410 \\
10062\end{array}$ & 23 & 33 & 563 & 29 & 21 & $\begin{array}{l}1600 \\
16175\end{array}$ \\
\hline 36 & Indústrias diversas & 395951 & 1156 & 160 & 30747 & 53305 & 87 & 227529 & 95 & 13740 & 48284 & 116 & 171 & 49031 \\
\hline 37 & $\begin{array}{l}\text { S.I.U.P. } \\
\text { S }\end{array}$ & 3444590 & 30508 & 42 & 262209 & 445146 & 338169 & 966304 & 1000636 & 336595 & 1023 & 38 & 115 & 652834 \\
\hline 38 & Construção civil & 15 & 4565 & 63 & 4969 & $\begin{array}{l}74310 \\
72069\end{array}$ & $\begin{array}{l}530109 \\
26242\end{array}$ & 766 & $\begin{array}{l}75494 \\
7540\end{array}$ & 17622 & $\begin{array}{r}1023 \\
982\end{array}$ & 72 & 29245 & $\begin{array}{l}052034 \\
45447\end{array}$ \\
\hline 39 & Comér & 31 & 75339 & 103 & 1555080 & 2822 & 1045 & 1859286 & 1871408 & 142114 & 1678013 & 232952 & 1156160 & 2077260 \\
\hline 40 & rodoviário & 112 & 12. & 156 & 294438 & 415 & 270 & 278654 & 384512 & 133264 & 41362 & 5886 & 281261 & 408596 \\
\hline 41 & Transp & 508242 & 1114 & 37002 & 19861 & 68453 & 6749 & 41255 & 72257 & 433 & 1986 & 88991 & 7397 & 1650 \\
\hline 42 & Transporte ferroviá & 228132 & 1779 & 42836 & 42956 & 68080 & 12697 & 68305 & 169876 & 416 & 1708880 & 42675 & 56022 & 13910 \\
\hline 43 & Transporte aquaviário & 122 & 45 & 419 & 12811 & 261 & 36 & 201 & 56 & 4 & 37 & 6 & 27 & 67 \\
\hline 44 & Atividades aux. dos transp. & 323970 & 4486 & 40175 & 64550 & 96682 & 50952 & 68616 & 109059 & 23511 & 300302 & 23655 & 59699 & 74523 \\
\hline 45 & Comunicacões & 862537 & 33365 & 461822 & 470707 & 395792 & 187613 & 605440 & 412487 & 40427 & 381853 & 53376 & 227687 & 319707 \\
\hline 46 & Instituiç̃ôs financeiras & 1189816 & 12523 & 174154 & 452291 & 595555 & 66882 & 359603 & 527585 & 98439 & 777763 & 85295 & 8459 & 295811 \\
\hline 47 & Serv. prest. às famílias & 142450 & 5198 & 72031 & 59368 & 63104 & 36272 & 66980 & 67150 & 8663 & 49541 & 7894 & 35075 & 91583 \\
\hline 48 & Serv. prest. às empresas & $\begin{array}{l}142430 \\
63344\end{array}$ & 20049 & 277959 & 485430 & $\begin{array}{l}05104 \\
562296\end{array}$ & 124518 & $\begin{array}{l}00980 \\
542661\end{array}$ & 346870 & $\begin{array}{l}8003 \\
40540\end{array}$ & $\begin{array}{l}49341 \\
394960\end{array}$ & 36921 & 653545 & 356439 \\
\hline 49 & $\begin{array}{l}\text { Aluguel de imóveis } \\
\text { Alisas }\end{array}$ & $\begin{array}{l}037344 \\
234300\end{array}$ & 6571 & 91190 & $\begin{array}{l}483400 \\
105631\end{array}$ & $\begin{array}{c}502200 \\
64720\end{array}$ & 70806 & $\begin{array}{l}542001 \\
188087\end{array}$ & $\begin{array}{l}34080 \\
113828\end{array}$ & $\begin{array}{l}013440 \\
6134\end{array}$ & $\begin{array}{l}594400 \\
73573\end{array}$ & $\begin{array}{l}30921 \\
12948\end{array}$ & $\begin{array}{c}035353 \\
62729\end{array}$ & $\begin{array}{l}147264 \\
14749\end{array}$ \\
\hline 50 & Administração pública & 224997 & 4599 & 63806 & 118597 & 180057 & 53211 & 943374 & 120461 & 9865 & 110739 & 108955 & 203360 & 106119 \\
\hline $\begin{array}{l}50 \\
51\end{array}$ & $\begin{array}{l}\text { Admimistraçaa publica } \\
\text { Serv. priv. não mercantis }\end{array}$ & $\begin{array}{c}224991 \\
0\end{array}$ & $\begin{array}{c}4599 \\
0\end{array}$ & $\begin{array}{c}63800 \\
0\end{array}$ & $\begin{array}{l}11859 / \\
0\end{array}$ & 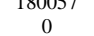 & $\begin{array}{c}53211 \\
0\end{array}$ & $\begin{array}{l}9433 / 4 \\
0\end{array}$ & 0 & $\begin{array}{c}9863 \\
0\end{array}$ & $110 / 39$ & 108953 & 203560 & 0 \\
\hline
\end{tabular}


APÊNDICE 1 - Matriz insumo-produto inter-regional Mato Grosso x resto do Brasil / 1999.

\begin{tabular}{|c|c|c|c|c|c|c|c|c|c|c|c|c|c|c|}
\hline \multicolumn{2}{|c|}{ resto do Brasil } & \multicolumn{13}{|c|}{ resto do Brasil } \\
\hline Setores & & 27 & 28 & 29 & 30 & 31 & 32 & 33 & 34 & 35 & 36 & 37 & 38 & 39 \\
\hline 1 & Cana-de-açúcar & & & & & & & & & & & & & \\
\hline 2 & Soja & 7 & 75586 & 250 & 218 & 448 & 1 & 3960177 & 3020 & 182180 & 1 & 1 & 2 & 0 \\
\hline 3 & Milho & 0 & 435794 & 4421 & 0 & 3 & 1 & 9345 & 558053 & 815446 & 1 & 1 & 2 & 0 \\
\hline 4 & Fruticultura & 4 & 1304170 & 155 & 135 & 4436 & 1 & 1757 & 1868 & 815343 & 1 & 1 & 2 & 0 \\
\hline 5 & Outras culturas & 4869339 & 8852693 & 183770 & 74540 & 1492 & 11359 & 13307 & 10539 & 457146 & 4 & 2 & 7 & 0 \\
\hline 6 & Aves & 0 & 86 & 3523463 & 0 & 0 & 0 & 0 & 0 & 97688 & 0 & 0 & 0 & 0 \\
\hline 7 & Bovinos & 0 & 16139 & 0 & 4824831 & 3189158 & 0 & 2866 & 9459 & 40467 & 247 & 0 & 0 & 0 \\
\hline 8 & Suínos & 0 & 0 & 5052836 & 0 & 2 & 0 & 1428 & 0 & 2435 & 0 & 0 & 0 & 0 \\
\hline 9 & Outros pecuária & 0 & 99 & 34844 & 0 & 3952 & 0 & 581739 & 482637 & 401751 & 28440 & 16796 & 0 & 0 \\
\hline 10 & Extrativismo vegetal & 1 & 5430 & 59 & 35 & 0 & 0 & 19 & 348 & 589 & 2047 & 70 & 6621 & 222 \\
\hline 11 & Silvicultura & 1 & 10 & 26 & 11 & 0 & 0 & 0 & 20 & 61 & 164 & 0 & 4816 & 0 \\
\hline 12 & Extrativismo animal & 0 & 0 & 0 & 0 & 0 & 0 & 0 & 0 & 2 & 0 & 0 & 0 & 0 \\
\hline 13 & Extrat. Mineral & 186 & 3156 & 4695 & 3373 & 181 & 237 & 2692 & 42919 & 70012 & 252233 & 15798 & 351391 & 5341 \\
\hline 14 & Siderurgia & 33358 & 408213 & 107842 & 43926 & 89569 & 99874 & 289367 & 108656 & 693229 & 591297 & 58199 & 21036200 & 131082 \\
\hline 15 & Maq. e implem. agrícolas & 168 & 1314 & 731 & 296 & 429 & 118698 & 1033 & 600 & 1855 & 1109 & 31746 & 22231 & 6506 \\
\hline 16 & Outras maq. e equip. & 11107 & 112356 & 64108 & 25873 & 30367 & 194855 & 60844 & 47670 & 143142 & 74776 & 1027898 & 1011831 & 310996 \\
\hline 17 & Eletro-eletrônicos & 1119 & 8167 & 4373 & 1791 & 2387 & 18088 & 4490 & 3305 & 10181 & 46814 & 340220 & 2472048 & 44257 \\
\hline 18 & Peças e veículos & 773 & 8539 & 4576 & 1853 & 2773 & 11302 & 6543 & 3655 & 11294 & 6490 & 114288 & 185200 & 23464 \\
\hline 19 & Madeira e mobiliário & 837 & 7510 & 15023 & 6298 & 2025 & 5273 & 2177 & 11503 & 34502 & 86368 & 4273 & 2483338 & 116075 \\
\hline 20 & cel., papel e gráfica & 64782 & 448886 & 112371 & 45346 & 82127 & 95400 & 116748 & 218101 & 660270 & 251790 & 125713 & 97617 & 1875853 \\
\hline 21 & Químicos diversos & 25232 & 194429 & 172574 & 72241 & 157428 & 146126 & 149138 & 195684 & 611739 & 455308 & 84751 & 4383108 & 644204 \\
\hline 22 & Âlcool & 153 & 2364 & 334 & 141 & 448 & 7247 & 534 & 14469 & 45882 & 2301 & 10781 & 11100 & 5880129 \\
\hline 23 & Refino d & 53660 & 224384 & 71551 & 28330 & 65930 & 116096 & 139717 & 111224 & 333679 & 402651 & 750701 & 1378060 & 18855213 \\
\hline 24 & Adubos & 74 & 774 & 189 & 78 & 59 & 346 & 326 & 390 & 1254 & 1577 & 117 & 2967 & 2920 \\
\hline 25 & Farmac. e veterinária & 166 & 4917 & 6612 & 2769 & 2311 & 1790 & 3071 & 31552 & 94715 & 3021 & 10240 & 3176 & 7499 \\
\hline 26 & Ind. têxtil e calçadista & 21527 & 85399 & 9988 & 26272 & 4695 & 248543 & 222424 & 10516 & 33745 & 162577 & 14138 & 55721 & 120334 \\
\hline 27 & Indústria do café & 1868195 & 3029 & 151 & 100 & 171 & 24 & 985 & 2069 & 5697 & 50 & 229 & 97 & 2192 \\
\hline 28 & Benef. Prod. vegetais & 5278 & 687859 & 32528 & 12740 & 46595 & 323 & 223232 & 1051375 & 3194961 & 452 & 612 & 557 & 4734 \\
\hline 29 & Abate de outros animais & 30 & 1281 & 1039326 & 32 & 174 & 42 & 44567 & 2712 & 119387 & 2452 & 409 & 135 & 3065 \\
\hline 30 & Abate de bovinos & 17 & 5550 & 44 & 982055 & 110 & 24 & 53295 & 2680 & 87932 & 4560 & 272 & 77 & 1740 \\
\hline 31 & Indústria de laticínios & 57 & 13223 & 1265 & 5116 & 1438226 & 77 & 1207 & 36310 & 115991 & 160 & 312 & 153 & 2908 \\
\hline 32 & Fabricação de açúcar & 77 & 119562 & 326 & 139 & 34869 & 1196242 & 395 & 177475 & 566850 & 170 & 17552 & 346 & 31884 \\
\hline 33 & Fab. óleos vegetais & 57 & 106741 & 5288 & 2211 & 32365 & 274 & 2941292 & 1562 & 2100250 & 400 & 438 & 479 & 3156 \\
\hline 34 & Raçõc & 20 & 508 & 91840 & 38505 & 26 & 57 & 636 & 305478 & 683 & 108 & 235 & 129 & 1949 \\
\hline 35 & d. alimentares & 2571 & 40594 & 1144 & 743 & 20014 & 2926 & 15154 & 4158 & 1223598 & 10702 & 901 & 482 & 84673 \\
\hline 36 & Indústrias diversas & 9565 & 12206 & 8382 & 3508 & 9997 & 9063 & 8294 & 6584 & 20158 & 122043 & 165884 & 398230 & 47801 \\
\hline 37 & $\begin{array}{l}\text { S.I.U.P. } \\
\text { lats }\end{array}$ & 46903 & 298409 & 210693 & 85030 & 91785 & 234084 & 160367 & 159053 & 482619 & 98047 & 14306362 & 209480 & 1927713 \\
\hline 38 & Construção civil & 7303 & 24849 & 29570 & 12396 & 13117 & 45187 & 12501 & 10894 & 33014 & 14810 & 218043 & 5120925 & 284087 \\
\hline 39 & Comércio & 298118 & 1898197 & 1035038 & 434277 & 336485 & 394416 & 911944 & 625353 & 1905164 & 465055 & 424986 & 4255885 & 2096726 \\
\hline 40 & Transporte rodoviário & 79485 & 356285 & 361175 & 198921 & 120385 & 175471 & 335449 & 89482 & 388831 & 77888 & 24463 & 1163458 & 2392761 \\
\hline 41 & Transp & 1857 & 17016 & 1203 & 1126 & 2826 & 8125 & 25858 & 198 & 668 & 271 & 9906 & 59637 & 778902 \\
\hline 42 & Trans & 723 & 8986 & 33 & 1392 & 6954 & 1425 & 6162 & 26564 & 87361 & 21429 & 262 & 66256 & 229860 \\
\hline 43 & & 8 & 137 & 63 & 107 & 9 & 9 & 11 & 91 & 659 & 176 & 14610 & 18553 & 136892 \\
\hline 44 & ansp. & 14527 & 6744 & 645 & 3490 & 2295 & 3269 & 63518 & 23753 & 84361 & 22143 & 27799 & 218941 & 618105 \\
\hline 45 & & & 1622 & & 578 & 616 & 59 & 872 & 784 & 2371 & 145 & & 454252 & \\
\hline 46 & & & & & & & & 194 & & & & & & 2359604 \\
\hline 47 & & & & & & & & & & & & & & \\
\hline 48 & & & & & & & & & & & & & & \\
\hline 49 & & & & 392 & 16454 & 15221 & 12 & 205 & 47 & 142 & & 372 & 157488 & 3569940 \\
\hline 50 & Administração pública & 20772 & 148725 & 43506 & 18060 & 26687 & 32994 & 43278 & 61527 & 174484 & 181196 & 115429 & 294783 & 1238052 \\
\hline 51 & Serv. priv. não mercantis & 0 & 0 & 0 & 0 & 0 & 0 & 0 & 0 & 0 & 0 & 0 & 0 & 0 \\
\hline
\end{tabular}


APÊNDICE 1 - Matriz insumo-produto inter-regional Mato Grosso x resto do Brasil / 1999.

\begin{tabular}{|c|c|c|c|c|c|c|c|c|c|c|c|c|c|}
\hline \multirow{2}{*}{\multicolumn{2}{|c|}{$\begin{array}{l}\text { resto do Brasil } \\
\text { Setores }\end{array}$}} & \multicolumn{12}{|c|}{ resto do Brasil } \\
\hline & & 40 & 41 & 42 & 43 & 44 & 45 & 46 & 47 & 48 & 49 & 50 & 51 \\
\hline 1 & Cana-de-açúcar & & & & & & & & & & & & \\
\hline 2 & Soja & 0 & 3 & 0 & 0 & 2 & 0 & 0 & 3711 & 0 & 0 & 3452 & 99 \\
\hline 3 & Miho & 0 & 2 & 0 & 0 & 2 & 0 & 0 & 2933 & 0 & 0 & 7 & 0 \\
\hline 4 & Fruticultura & 0 & 0 & 0 & 0 & 0 & 0 & 0 & 587224 & 0 & 0 & 649725 & 13971 \\
\hline 5 & Outras culturas & 0 & 7 & 0 & 0 & 6 & 0 & 0 & 1187260 & 0 & 0 & 1096320 & 25659 \\
\hline 6 & Aves & 0 & 2 & 0 & 0 & 2 & 0 & 0 & 206337 & 0 & 0 & 39698 & 6402 \\
\hline 7 & Bovinos & 0 & 7 & 0 & 0 & 6 & 0 & 0 & 189362 & 0 & 0 & 18627 & 4837 \\
\hline 8 & Suínos & 0 & 1 & 0 & 0 & 1 & 0 & 0 & 16167 & 0 & 0 & 5211 & 626 \\
\hline 9 & Outros pecuária & 0 & 15 & 0 & 0 & 13 & 0 & 0 & 184327 & 0 & 0 & 91629 & 2602 \\
\hline 10 & Extrativismo vegetal & 43 & 0 & 0 & 0 & 27 & 0 & 0 & 192 & 0 & 0 & 143 & 0 \\
\hline 11 & Silvicultura & 0 & 0 & 0 & 0 & 0 & 0 & 0 & 0 & 0 & 0 & 114 & 0 \\
\hline 12 & Extrativismo animal & 0 & 1 & 0 & 0 & 1 & 0 & 0 & 84871 & 0 & 0 & 1 & 0 \\
\hline 13 & Extrat. Mineral & 591 & 629 & 58 & 29 & 226 & 1032 & 8343 & 3195 & 11785 & 568 & 14238 & 776 \\
\hline 14 & $\begin{array}{l}\text { Siderurgia } \\
\end{array}$ & 38906 & 9254 & 74066 & 2838 & 61693 & 292903 & 19461 & 946855 & 47505 & 4006 & 347654 & 19249 \\
\hline 15 & Maq. e implem. agrícolas & 1310 & 528 & 368 & 66 & 736 & 1940 & 3271 & 8039 & 3870 & 812 & 8641 & 373 \\
\hline 16 & Outras maq. e equip. & 55490 & 20692 & 46242 & 3084 & 41750 & 225849 & 45469 & 218155 & 187057 & 80985 & 271676 & 5180 \\
\hline 17 & Eletro-eletrônicos & 8868 & 3205 & 3161 & 450 & 7577 & 750879 & 3809 & 308201 & 61536 & 20063 & 203655 & 1726 \\
\hline 18 & Peças e veículos & 1165716 & 470699 & 156463 & 57218 & 336137 & 82816 & 7977 & 2885883 & 7270 & 4060 & 527636 & 709 \\
\hline 19 & Madeira e mobiliário & 25595 & 1575 & 562 & 233 & 14160 & 2911 & 12109 & 195641 & 18914 & 1182 & 108389 & 1276 \\
\hline 20 & cel., papel e gráfica & 108681 & 42030 & 4803 & 2805 & 49885 & 236981 & 434426 & 438424 & 3643926 & 17608 & 2756475 & 22018 \\
\hline 21 & Químicos diversos & 1716492 & 251931 & 75125 & 37010 & 194408 & 178892 & 6677 & 2951801 & 22885 & 59812 & 1102331 & 16111 \\
\hline 22 & Âlcool & 41157 & 2331 & 1177 & 494 & 4839 & 146503 & 336 & 51305 & 469 & 64 & 40637 & 111 \\
\hline 23 & Refino do petróleo & 6476073 & 2198838 & 198907 & 357635 & 664936 & 3791 & 29438 & 349938 & 213147 & 3082 & 387941 & 20722 \\
\hline 24 & Adubos e fertilizantes & & & & & 228 & 150 & 307 & 4981 & 189 & 12 & 2220 & 20 \\
\hline 25 & $\begin{array}{l}\text { Auubos e lerturzantes } \\
\text { Farmac. e veterinária }\end{array}$ & 318 & 1192 & 28 & $\begin{array}{l}44 \\
11\end{array}$ & 832 & $\begin{array}{l}150 \\
822\end{array}$ & $\begin{array}{r}301 \\
2465\end{array}$ & $\begin{array}{c}4911405 \\
81105\end{array}$ & $\begin{array}{l}189 \\
1786\end{array}$ & $\begin{array}{l}12 \\
261\end{array}$ & 883306 & 251 \\
\hline 26 & Ind. têxtil e calçadista & 164680 & 40845 & 27960 & 7786 & 70090 & 48720 & 16319 & 1585084 & 22659 & 1475 & 354924 & 2067 \\
\hline 27 & Indústria do café & 91 & 74 & 2 & 3 & 48 & 248 & 817 & 426598 & 259 & 27 & 51318 & 11529 \\
\hline 28 & Benef. Prod. vegetais & 196 & 1323 & 5 & 7 & 1067 & 536 & 1765 & 721593 & 559 & 58 & 298779 & 12158 \\
\hline 29 & Abate de outros animais & 127 & 1134 & 3 & 5 & 944 & 347 & 1143 & 871165 & 362 & 38 & 236286 & $\begin{array}{l}12100 \\
35350\end{array}$ \\
\hline 30 & Abate de bovinos & 72 & 644 & 2 & 3 & 536 & 230 & 649 & 569729 & 205 & 21 & 178786 & 22003 \\
\hline 31 & Indústria de laticínios & 120 & 105 & 3 & 3 & 67 & 329 & 1084 & 392303 & 343 & 36 & 451346 & 11904 \\
\hline 32 & Fabricação de açúcar & 411 & 142 & 48 & 11 & 238 & 1214 & 1507 & 648182 & 889 & 406 & 26538 & 15147 \\
\hline 33 & Fab. óleos vegetais & 173 & 538 & 25 & 9 & 429 & 349 & 1148 & 401325 & 363 & 38 & 6429 & 10659 \\
\hline 34 & Rações & 81 & 75 & 2 & 2 & 48 & 221 & 727 & 1517 & 230 & 24 & 1012 & 49 \\
\hline 35 & Outros prod. alimentares & 815 & 155302 & 14 & 171 & 132141 & 2707 & 2526 & 5077806 & 800 & 83 & 200180 & 49278 \\
\hline 36 & Indústrias diversas & 35989 & 9594 & 3031 & 1634 & 7028 & 37667 & 478998 & 141743 & 805193 & 31395 & 864900 & 47071 \\
\hline 37 & S.I.U.P. & 99723 & 35799 & 37049 & 5173 & 137642 & 204345 & 392696 & 1879304 & 473109 & 266277 & 3235765 & 77094 \\
\hline 38 & Construção civil & 181158 & 54755 & 16157 & 9624 & 55120 & 253014 & 0 & 371618 & 138755 & 4151431 & 1177763 & 18322 \\
\hline 39 & Comércio & 1505750 & 469565 & 132800 & 79850 & 530593 & 400939 & 925060 & 3916068 & 1051294 & 41769 & 5649911 & 69270 \\
\hline 40 & Transporte rodoviário & 1730191 & 368579 & 82982 & 93082 & 267183 & 108295 & 255860 & 482020 & 67756 & 4315 & 798048 & 9291 \\
\hline 41 & Transporte aéreo & 562842 & 854886 & 67602 & 60682 & 174474 & 8023 & 113551 & 157302 & 136792 & 112 & 56566 & 350 \\
\hline 42 & Transporte ferroviário & 166099 & 88511 & 145133 & 17908 & 51489 & 426 & 4175 & 46414 & 817 & 77 & 119223 & 200 \\
\hline 43 & Transporte aquaviário & 98920 & 52712 & 11881 & 104312 & 30664 & 254 & 71751 & 27626 & 90634 & 2123 & 582687 & 9905 \\
\hline 44 & Atividades aux. dos transp. & 446175 & 236526 & 53366 & 47806 & 408493 & 32917 & 629681 & 128871 & 248733 & 1238 & 404783 & 3527 \\
\hline 45 & Comunicações & 600631 & 264928 & 71733 & 36100 & 209207 & 323228 & 1445457 & 1106619 & 1597890 & 86765 & 1441117 & 33886 \\
\hline 46 & Instituic & 795261 & 250542 & 6151 & 33422 & 141503 & 529730 & 6286113 & 556886 & 475341 & 215091 & 1200519 & 936 \\
\hline 47 & Serv. pi & 157420 & 49181 & 1377 & 815 & 4685 & 610735 & 3383644 & 1006027 & 203229 & 5440 & 9142525 & 14083 \\
\hline 48 & Serv & 793998 & 4015 & 491 & 29477 & 188747 & 598971 & 6206732 & 1458627 & 2566282 & 85 & 11474525 & 44145 \\
\hline $\begin{array}{l}40 \\
49\end{array}$ & & & 120 & 34 & 423 & $\begin{array}{l}700 \\
78\end{array}$ & 40 & & 303 & 421 & 43961 & 1130712 & 83972 \\
\hline 50 & & 15152 & 76667 & 1012 & 5680 & 3992 & 126048 & 1039866 & 377085 & 861423 & 16546 & 2213861 & 11842 \\
\hline 51 & Serv. priv. não mercantis & 0 & $\begin{array}{c}000 \\
0\end{array}$ & 0 & 0 & 0 & 0 & 0 & 0 & 0 & $\begin{array}{c}0.44 \\
0\end{array}$ & 0 & 0 \\
\hline
\end{tabular}


APÊNDICE 1 - Matriz insumo-produto inter-regional Mato Grosso x resto do Brasil / 1999.

\begin{tabular}{|c|c|c|c|c|c|c|c|c|c|}
\hline & & MT & $\mathrm{RBr}$ & & & & MT & & \\
\hline & Mato Grosso & Dummy & Dummy & CI total & $\begin{array}{c}\text { Form bruta de } \\
\text { capital fixo }\end{array}$ & Exportação & $\begin{array}{l}\begin{array}{l}\text { Variação de } \\
\text { estoque }\end{array} \\
\end{array}$ & $\begin{array}{l}\text { Consumo da } \\
\text { adm. pública } \\
\end{array}$ & $\begin{array}{c}\text { Consumo das } \\
\text { famílias }\end{array}$ \\
\hline 1 & Cana-de-açúcar & & & & & & & & \\
\hline 2 & Soja & 0 & 0 & 1142044 & 0 & 512140 & -110679 & 0 & 30918 \\
\hline 3 & Milho & 0 & 0 & 130625 & 0 & 57 & -5971 & 0 & 3806 \\
\hline 4 & Fruticultura & 0 & 0 & 77209 & 2703 & 37 & -19371 & 0 & 19523 \\
\hline 5 & Outras culturas & 0 & 0 & 1090317 & 44098 & 1194 & -48214 & 0 & 71461 \\
\hline 6 & Aves & 0 & 0 & 93281 & 0 & 108 & -13675 & 0 & 22259 \\
\hline 7 & Bovinos & 0 & 0 & 688765 & 0 & 14322 & 751293 & 0 & 62323 \\
\hline 8 & Suínos & 0 & 0 & 167844 & 0 & 0 & -74801 & 0 & 3939 \\
\hline 9 & Outros pecuária & 0 & 0 & 156953 & 0 & 1890 & -34617 & 0 & 186762 \\
\hline 10 & Extrativismo vegetal & 0 & 0 & 172587 & 1 & 979 & -73189 & 0 & 380 \\
\hline 11 & Silvicultura & 0 & 0 & 339 & 12 & 61 & 88 & 0 & 4 \\
\hline 12 & Extrativismo animal & 0 & 0 & 2177 & 0 & 0 & -18623 & 0 & 20144 \\
\hline 13 & Extrat. Mineral & 0 & 0 & 273844 & 245 & 492 & -15259 & 0 & 14031 \\
\hline 14 & Siderurgia & 0 & 0 & 167195 & 18 & 40006 & 2936 & 0 & 5970 \\
\hline 15 & Maq. e implem. agrícolas & 0 & 0 & 3212 & 3 & 57 & 1759 & 0 & 1282 \\
\hline 16 & Outras maq. e equip. & 0 & 0 & 1069 & 1 & 259 & 164 & 0 & 382 \\
\hline 17 & Eletro-eletrônicos & 0 & 0 & 43 & 0 & 7 & 196 & 0 & 3 \\
\hline 18 & Peças e veículos & 0 & 0 & 227 & 0 & 9 & 500 & 0 & 3 \\
\hline 19 & Madeira e mobiliário & 0 & 0 & 249827 & 3530 & 87166 & -4412 & 0 & 5373 \\
\hline 20 & cel., papel e gráfica & 0 & 0 & 17827 & 20 & 28 & 15104 & 0 & 4768 \\
\hline 21 & Químicos diversos & 0 & 0 & 30215 & 11 & 18797 & -552 & 0 & 247 \\
\hline 22 & Álcool & 0 & 0 & 212076 & 31 & 156 & -8805 & 0 & 34673 \\
\hline 23 & Refino do petróleo & 0 & 0 & 39223 & -24 & 16971 & 31757 & 0 & 632 \\
\hline 24 & Adubos e fertilizantes & 0 & 0 & 9621 & 9 & 428 & 14319 & 0 & 123 \\
\hline 25 & Farmac. e veterinária & 0 & 0 & 781 & 1 & 156 & 9130 & 0 & 144 \\
\hline 26 & Ind. têxtil e calçadista & 0 & 0 & 8510 & 2 & 23879 & -904 & 0 & 8416 \\
\hline 27 & Indústria do café & 0 & 0 & 1374 & 1 & 0 & 6769 & 0 & 69 \\
\hline 28 & Benef. Prod. vegetais & 0 & 0 & 20189 & 50 & 655 & 22562 & 0 & 39497 \\
\hline 29 & Abate de outros animais & 0 & 0 & 60246 & 21 & 12041 & -40570 & 0 & 178277 \\
\hline 30 & Abate de bovinos & 0 & 0 & 74471 & 21 & 85455 & -57645 & 0 & 88272 \\
\hline 31 & Indústria de laticínios & 0 & 0 & 4207 & 17 & 75 & 14854 & 0 & 23008 \\
\hline 32 & Fabricação de açúcar & 0 & 0 & 59254 & 19 & 15024 & 32939 & 0 & 29058 \\
\hline 33 & Fab. óleos vegetais & 0 & 0 & 509699 & 190 & 416907 & -2410 & 0 & 78587 \\
\hline 34 & Rações & 0 & 0 & 9524 & 6 & 42 & 20839 & 0 & 4919 \\
\hline 35 & Outros prod. alimentares & 0 & 0 & 56160 & 58 & 1822 & -2115 & 0 & 88681 \\
\hline 36 & Indústrias diversas & 0 & 0 & 11074 & 466 & 70 & 7646 & 0 & 7239 \\
\hline 37 & S.I.U.P. & 0 & 0 & 555548 & 78 & 289 & -346428 & 0 & 229680 \\
\hline 38 & Construção civil & 0 & 0 & 173912 & 1132023 & 116 & 154472 & 0 & 94 \\
\hline 39 & Comércio & 0 & 0 & 1877194 & 80164 & 130232 & 767830 & 0 & 894850 \\
\hline 40 & Transporte rodoviário & 0 & 0 & 421652 & 3072 & 24448 & -185153 & 0 & 282866 \\
\hline 41 & Transporte aéreo & 0 & 0 & 74908 & 877 & 15595 & -66870 & 0 & 30600 \\
\hline 42 & Transporte ferroviário & 0 & 0 & 54632 & 259 & 4948 & -45763 & 0 & 3319 \\
\hline 43 & Transporte aquaviário & 0 & 0 & 35825 & 154 & 3806 & -30452 & 0 & 1181 \\
\hline 44 & Atividades aux. dos transp. & 0 & 0 & 76395 & 691 & 13155 & -66691 & 0 & 37377 \\
\hline 45 & Comunicações & 0 & 0 & 310508 & 137 & 871 & -180119 & 0 & 230861 \\
\hline 46 & Instituições financeiras & 199817 & 0 & 495474 & 0 & 7311 & -341541 & 0 & 232168 \\
\hline 47 & Serv. prest. às famílias & 0 & 0 & 277038 & 110 & 45656 & -174416 & 0 & 1024138 \\
\hline 48 & Serv. prest. às empresas & 0 & 0 & 625724 & 16163 & 59397 & -310398 & 0 & 14675 \\
\hline 49 & Aluguel de imóveis & 0 & 0 & 192900 & 0 & 0 & -1116523 & 0 & 1449550 \\
\hline 50 & Administração pública & 0 & 0 & 277875 & 6179 & 21621 & -71951 & 3001441 & 26190 \\
\hline 51 & Serv. priv. ño mercantis & 0 & 0 & 0 & 0 & 0 & -18171 & 0 & 169880 \\
\hline
\end{tabular}


APÊNDICE 1 - Matriz insumo-produto inter-regional Mato Grosso x resto do Brasil / 1999.

\begin{tabular}{|c|c|c|c|c|c|c|c|c|}
\hline & Mato Grosso & $\begin{array}{c}\text { Form bruta de } \\
\text { capital fixo }\end{array}$ & Exportação & $\begin{array}{c}\text { Variação de } \\
\text { estoque }\end{array}$ & $\begin{array}{l}\text { Consumo da } \\
\text { adm. pública }\end{array}$ & $\begin{array}{l}\text { Consumo das } \\
\text { famílias }\end{array}$ & $\begin{array}{c}\text { Demanda } \\
\text { final }\end{array}$ & $\begin{array}{c}\begin{array}{c}\text { Demanda } \\
\text { total }\end{array} \\
\end{array}$ \\
\hline 1 & Cana-de-açúcar & & & & & & & \\
\hline 2 & Soja & 0 & 0 & 0 & 0 & 4813 & 437193 & 1579237 \\
\hline 3 & Milho & 0 & 0 & 0 & 0 & 884 & -1223 & 129402 \\
\hline 4 & Fruticultura & 975 & 0 & 0 & 0 & 13854 & 17721 & 94930 \\
\hline 5 & Outras culturas & 5287 & 0 & 0 & 0 & 21956 & 95783 & 1186099 \\
\hline 6 & Aves & & 0 & 0 & 0 & 12798 & 21490 & 114771 \\
\hline 7 & Bovinos & 0 & 0 & 0 & 0 & 34676 & 862614 & 1551378 \\
\hline 8 & Suínos & 0 & 0 & 0 & 0 & 1879 & -68982 & 98862 \\
\hline 9 & Outros pecuária & 0 & 0 & 0 & 0 & 389905 & 543941 & 700894 \\
\hline 10 & Extrativismo vegetal & 14 & 0 & 0 & 0 & 429 & -71385 & 101202 \\
\hline 11 & $\begin{array}{l}\text { Silvicultura } \\
\text { love }\end{array}$ & 3 & 0 & 0 & 0 & 2 & 170 & 510 \\
\hline 12 & Extrativismo animal & 0 & 0 & 0 & 0 & 18451 & 19973 & 22150 \\
\hline 13 & Extrat. Mineral & 33 & 0 & 0 & 0 & 458 & -1 & 273842 \\
\hline 14 & Siderurgia & 33 & 0 & 0 & 0 & 820 & 49782 & 216978 \\
\hline 15 & Maq. e implem. agrí́colas & 55 & 0 & 0 & 0 & 15 & 3170 & 6382 \\
\hline 16 & Outras maq. e equip. & 22 & 0 & 0 & 0 & 5 & 833 & 1902 \\
\hline 17 & Eletro-eletrônicos & 16 & 0 & 0 & 0 & 23 & 246 & 289 \\
\hline 18 & Peças e veículos & 12 & 0 & 0 & 0 & 34 & 558 & 785 \\
\hline 19 & Madeira e mobiliário & 28007 & 0 & 0 & 0 & 6548 & 126213 & 376039 \\
\hline 20 & cel., papel e gráfica & 5 & 0 & 0 & 0 & $\begin{array}{l}8340 \\
885\end{array}$ & 20811 & 38638 \\
\hline 21 & Químicos diversos & 1 & 0 & 0 & 0 & 699 & 19204 & 49419 \\
\hline 22 & Âlcool & 2 & 0 & 0 & 0 & 5083 & 31139 & 243215 \\
\hline 23 & Refino do petróleo & -23 & 0 & 0 & 0 & 428 & 49741 & 88964 \\
\hline 24 & Adubos e fertilizantes & 1 & 0 & 0 & 0 & 8 & 14887 & 24508 \\
\hline 25 & Farmac. e veterinária & 0 & 0 & 0 & 0 & 442 & 9873 & 10654 \\
\hline 26 & Ind. têxtil e calçadista & 0 & 0 & 0 & 0 & 2659 & 34053 & 42562 \\
\hline 27 & Indústria do café & 0 & 0 & 0 & 0 & 137 & 6975 & 8350 \\
\hline 28 & Benef. Prod. vegetais & 6 & 0 & 0 & 0 & 8707 & 71477 & 91666 \\
\hline 29 & Abate de outros animais & 1 & 0 & 0 & 0 & 146854 & 296624 & 356869 \\
\hline 30 & Abate de bovinos & 1 & 0 & 0 & 0 & 174602 & 290706 & 365177 \\
\hline 31 & Indústria de laticínios & 1 & 0 & 0 & 0 & 2117 & 40072 & 44279 \\
\hline 32 & Fabricação de açúcar & 1 & 0 & 0 & 0 & 3181 & 80222 & 139476 \\
\hline 33 & Fab. óleos vegetais & 12 & 0 & 0 & 0 & 123053 & 616338 & 1126037 \\
\hline 34 & Raçōes & 1 & 0 & 0 & 0 & 1163 & 26969 & 36493 \\
\hline 35 & Outros prod. alimentares & 7 & 0 & 0 & 0 & 29249 & 117702 & 173862 \\
\hline 36 & Indústrias diversas & 77 & 0 & 0 & 0 & 789 & 16288 & 27362 \\
\hline 37 & S.I.U.P. & 1 & 0 & 0 & 0 & 74848 & -41532 & 514016 \\
\hline 38 & Construção civil & 108247 & 0 & 0 & 0 & 8 & 1394961 & 1568873 \\
\hline 39 & $\begin{array}{l}\text { Comércio } \\
\text { lair }\end{array}$ & 47787 & 0 & 0 & 0 & 708105 & 2628968 & 4506162 \\
\hline 40 & Transporte rodoviário & 896 & 0 & 0 & 0 & 71718 & 197848 & 619500 \\
\hline 41 & Transporte aéreo & 193 & 0 & 0 & 0 & 5936 & $\begin{array}{l}13668 \\
-13640\end{array}$ & 61240 \\
\hline 42 & Transporte ferroviário & 57 & 0 & 0 & 0 & 620 & -36560 & 18072 \\
\hline 43 & Transporte aquaviário & 34 & 0 & 0 & 0 & 214 & -25062 & 10763 \\
\hline 44 & Atividades aux. dos transp. & 8 & 0 & 0 & 0 & 2155 & -13305 & 63090 \\
\hline 45 & Comunicações & 15 & 0 & 0 & 0 & 3920 & 55685 & 366193 \\
\hline 46 & Instituições financeiras & 0 & 0 & 0 & 0 & 1797 & -100265 & 395209 \\
\hline 47 & Serv. prest. às famílias & 8 & 0 & 0 & 0 & 178238 & 1073735 & 1350773 \\
\hline 48 & Serv. prest. às empresas & 289 & 0 & 0 & 0 & 185 & -219690 & 406034 \\
\hline 49 & Aluguel de imóveis & 0 & 0 & 0 & 0 & 10145 & 343171 & 536072 \\
\hline 50 & Administração pública & 288 & 0 & 0 & 0 & 7650 & 2991417 & 3269292 \\
\hline 51 & Serv. priv. não mercantis & 0 & 0 & 0 & 0 & 0 & 151709 & 151709 \\
\hline
\end{tabular}


APÊNDICE 1 - Matriz insumo-produto inter-regional Mato Grosso x resto do Brasil / 1999.

\begin{tabular}{|c|c|c|c|c|c|c|c|c|c|}
\hline & & MT & $\mathbf{R B r}$ & & & & MT & & \\
\hline & resto do Brasil & Dummy & Dummy & CI total & $\begin{array}{c}\text { Form bruta de } \\
\text { capital fixo }\end{array}$ & Exportação & $\begin{array}{l}\text { Variação de } \\
\text { estoque }\end{array}$ & $\begin{array}{l}\text { Consumo da } \\
\text { adm. pública }\end{array}$ & $\begin{array}{c}\text { Consumo das } \\
\text { famílias }\end{array}$ \\
\hline 1 & Cana-de-açúcar & & & & & & & & \\
\hline 2 & Soja & 0 & 0 & 4535240 & 0 & 0 & 0 & 0 & 1093 \\
\hline 3 & Milho & 0 & 0 & 4615905 & 0 & 0 & 0 & 0 & 1740 \\
\hline 4 & Fruticultura & 0 & 0 & 4337050 & 2068 & 0 & 0 & 0 & 5889 \\
\hline 5 & Outras culturas & 0 & 0 & 26876517 & 45522 & 0 & 0 & 0 & 74299 \\
\hline 6 & Aves & 0 & 0 & 4975445 & 0 & 0 & 0 & 0 & 2088 \\
\hline 7 & Bovinos & 0 & 0 & 10652996 & 0 & 0 & 0 & 0 & 13833 \\
\hline 8 & Suínos & 0 & 0 & 5123025 & 0 & 0 & 0 & 0 & 177 \\
\hline 9 & Outros pecuária & 0 & 0 & 3335879 & 0 & 0 & 0 & 0 & 12172 \\
\hline 10 & Extrativismo vegetal & 0 & 0 & 1941270 & 4 & 0 & 0 & 0 & 107 \\
\hline 11 & Silvicultura & 0 & 0 & 1802929 & 1673 & 0 & 0 & 0 & 619 \\
\hline 12 & Extrativismo animal & 0 & 0 & 85117 & 0 & 0 & 0 & 0 & 1467 \\
\hline 13 & Extrat. Mineral & 0 & 0 & 20348273 & 32 & 0 & 0 & 0 & 577 \\
\hline 14 & Siderurgia & 0 & 0 & 73834232 & 3785 & 0 & 0 & 0 & 50174 \\
\hline 15 & Maq. e implem. agrícolas & 0 & 0 & 492051 & 4005 & 0 & 0 & 0 & 542 \\
\hline 16 & Outras maq. e equip. & 0 & 0 & 11732490 & 55536 & 0 & 0 & 0 & 8447 \\
\hline 17 & Eletro-eletrônicos & 0 & 0 & 7867293 & 26793 & 0 & 0 & 0 & 133367 \\
\hline 18 & Peças e veículos & 0 & 0 & 13025086 & 24845 & 0 & 0 & 0 & 203352 \\
\hline 19 & Madeira e mobiliário & 0 & 0 & 6295862 & 3751 & 0 & 0 & 0 & 84760 \\
\hline 20 & cel., papel e gráfica & 0 & 0 & 22684610 & 176 & 0 & 0 & 0 & 51644 \\
\hline 21 & Químicos diversos & 0 & 0 & 39148458 & 55 & 0 & 0 & 0 & 30947 \\
\hline 22 & Ấlcool & 0 & 0 & 6875332 & 0 & 0 & 0 & 0 & 2508 \\
\hline 23 & Refino do petróleo & 0 & 0 & 69212944 & 156 & 0 & 0 & 0 & 45260 \\
\hline 24 & Adubos e fertilizantes & 0 & 0 & 7729161 & 0 & 0 & 0 & 0 & 57 \\
\hline 25 & Farmac. e veterinária & 0 & 0 & 3458724 & 0 & 0 & 0 & 0 & 201345 \\
\hline 26 & Ind. têxtil e calçadista & 0 & 0 & 16856771 & 61 & 0 & 0 & 0 & 238388 \\
\hline 27 & Indústria do café & 0 & 0 & 2384536 & 0 & 0 & 0 & 0 & 44523 \\
\hline 28 & Benef. Prod. vegetais & 0 & 0 & 6584949 & 85 & 0 & 0 & 0 & 163630 \\
\hline 29 & Abate de outros animais & 0 & 0 & 2786207 & 0 & 0 & 0 & 0 & 12451 \\
\hline 30 & Abate de bovinos & 0 & 0 & 1940978 & 0 & 0 & 0 & 0 & 6858 \\
\hline 31 & Indústria de laticínios & 0 & 0 & 2500967 & 0 & 0 & 0 & 0 & 63115 \\
\hline 32 & Fabricação de açúcar & 0 & 0 & 3378901 & 0 & 0 & 0 & 0 & 1835 \\
\hline 33 & Fab. óleos vegetais & 0 & 0 & 7993379 & 0 & 0 & 0 & 0 & 5757 \\
\hline 34 & Racōes & 0 & 0 & 4706549 & 5 & 0 & 0 & 0 & 21058 \\
\hline 35 & Outros prod. alimentares & 0 & 0 & 7262298 & 44 & 0 & 0 & 0 & 200231 \\
\hline 36 & Indústrias diversas & 0 & 0 & 4382297 & 2492 & 0 & 0 & 0 & 35966 \\
\hline 37 & S.I.U.P. & 0 & 0 & 35665732 & 8 & 0 & 0 & 0 & 15253 \\
\hline 38 & Construção civil & 0 & 0 & 13104256 & 165511 & 0 & 0 & 0 & 0 \\
\hline 39 & Comércio & 0 & 0 & 53691889 & 444 & 0 & 0 & 0 & 26480 \\
\hline 40 & Transporte rodoviário & 0 & 0 & 15633767 & 0 & 0 & 0 & 0 & 354 \\
\hline 41 & Transporte aéreo & 0 & 0 & 4306600 & 130 & 0 & 0 & 0 & 4503 \\
\hline 42 & Transporte ferroviário & 0 & 0 & 3840534 & 38 & 0 & 0 & 0 & 483 \\
\hline 43 & Transporte aquaviário & 0 & 0 & 1499643 & 23 & 0 & 0 & 0 & 170 \\
\hline 44 & Atividades aux. dos transp. & 0 & 0 & 5256755 & 99 & 0 & 0 & 0 & 4738 \\
\hline 45 & Comunicações & 0 & 0 & 16814654 & 146 & 0 & 0 & 0 & 35063 \\
\hline 46 & Instituições financeiras & 0 & 41017687 & 62467275 & 0 & 0 & 0 & 0 & 33049 \\
\hline 47 & Serv. prest. às famílias & 0 & 0 & 17302590 & 8 & 0 & 0 & 0 & 43298 \\
\hline 48 & Serv. prest. às empresas & 0 & 0 & 41747507 & 2918 & 0 & 0 & 0 & 2222 \\
\hline 49 & Aluguel de imóveis & 0 & 0 & 9898361 & 0 & 0 & 0 & 0 & 217138 \\
\hline 50 & Administracão pública & 0 & 0 & 10312484 & 771 & 0 & 0 & 0 & 17295 \\
\hline 51 & Serv. priv. ño mercantis & 0 & 0 & 0 & 0 & 0 & 0 & 0 & 0 \\
\hline
\end{tabular}


APÊNDICE 1 - Matriz insumo-produto inter-regional Mato Grosso x resto do Brasil / 1999.

\begin{tabular}{|c|c|c|c|c|c|c|c|c|}
\hline & \multicolumn{8}{|c|}{$\mathrm{RBr}$} \\
\hline & resto do Brasil & $\begin{array}{c}\text { Form bruta de } \\
\text { capital fixo }\end{array}$ & Exportaç̃o & 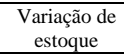 & $\begin{array}{l}\text { Consumo da } \\
\text { adm. pública }\end{array}$ & $\begin{array}{l}\text { Consumo das } \\
\text { famílias }\end{array}$ & $\begin{array}{c}\text { Demanda } \\
\text { final }\end{array}$ & $\begin{array}{c}\text { Demanda } \\
\text { total }\end{array}$ \\
\hline 1 & Cana-de-açúcar & 1 & 80647 & 29608 & 0 & 107469 & 218168 & 5299332 \\
\hline 2 & Soja & 1 & 1946803 & -143494 & 0 & 142023 & 1946425 & 6481665 \\
\hline 3 & Milho & 1 & 12776 & 260929 & 0 & 246640 & 522087 & 5137992 \\
\hline 4 & Fruticultura & 141361 & 346970 & -413183 & 0 & 1578921 & 1662026 & 5999076 \\
\hline 5 & Outras culturas & 2684687 & 769664 & 162292 & 0 & 9531528 & 13267993 & 40144510 \\
\hline 6 & Aves & 1 & 284688 & 43860 & 0 & 2203487 & 2534124 & 7509569 \\
\hline 7 & Bovinos & 3 & 48403 & 5969821 & 0 & 3712287 & 9744346 & 20397342 \\
\hline 8 & Suínos & 1 & 11743 & -1405564 & 0 & 185444 & -1208199 & 3914826 \\
\hline & Outros pecuária & & 203947 & 3589611 & 0 & 12806384 & 16612120 & 19947999 \\
\hline 10 & Extrativismo vegetal & 1076 & 57931 & -290829 & 0 & 32263 & -199446 & 1741824 \\
\hline 11 & Silvicultura & 55776 & 48358 & -228586 & 0 & 44776 & -77384 & 1725544 \\
\hline 12 & Extrativismo animal & 0 & 6716 & 36290 & 0 & 1503371 & 1547844 & 1632961 \\
\hline 13 & Extrat. Mineral & 10372 & 2249722 & -131765 & 0 & 83014 & 2211952 & 22560225 \\
\hline 14 & Siderurgia & 848080 & 13007814 & 479610 & 0 & 3883021 & 18272484 & 92106716 \\
\hline 15 & Maq.e implem. agrícolas & 884716 & 85440 & 453585 & 0 & 75760 & 1504047 & 1996098 \\
\hline 16 & Outras maq. e equip. & 12267403 & 2800372 & -227766 & 0 & 1114950 & 16018943 & 27751433 \\
\hline 17 & Eletro-eletrônicos & 5918758 & 3948235 & 246093 & 0 & 9109091 & 19382338 & 27249630 \\
\hline 18 & Pecas e veículos & 5484775 & 10193146 & 481297 & 0 & 13807050 & 30194465 & $\begin{array}{l}2 / 249030 \\
43219551\end{array}$ \\
\hline 19 & Madeira e mobiliário & 1500908 & 2321889 & -96019 & 0 & 5913622 & 9728912 & 45219531 \\
\hline 20 & cel. papel e gráfica & 46586 & 3017004 & -122646 & 0 & 3997144 & 6089907 & $\begin{array}{l}160247 / 4 \\
2067517\end{array}$ \\
\hline 21 & $\begin{array}{l}\text { Ouímicos diversos } \\
\text { Opicas }\end{array}$ & 24587 & 3741999 & 77899 & 0 & 2290118 & 6165605 & $\begin{array}{l}296 / 4517 \\
45314062\end{array}$ \\
\hline 22 & Alcool & 1216 & 158437 & -926781 & 0 & 2387287 & 1622666 & $\begin{array}{l}45314062 \\
8497908\end{array}$ \\
\hline 23 & Refino do petróleo & -19397 & 2359720 & 427424 & 0 & 3114600 & 5927764 & 8497998 \\
\hline 24 & Adubos e fertilizantes & 2098 & 68037 & -194553 & 0 & 44611 & -78849 & 75140707 \\
\hline 25 & Farmac e e eterinúrio & 2754 & 609081 & 156281 & 0 & 1626403 & 1595865 & 7650311 \\
\hline 26 & Ind têxtil e calcadista & 21865 & 4441271 & 1704 & 0 & 16015005 & 20149098 & 18054588 \\
\hline 27 & Indústria do café & 1226 & 3400798 & 1870323 & 0 & 30018 & 886504 & 38355957 \\
\hline 28 & Industrat do care & 11007 & 3357607 & 100836 & 0 & 1631116 & - & 10749589 \\
\hline 29 & Abate de outros animais & 1074 & 159320 & 45192 & 0 & 12013057 & 166504 & 26757129 \\
\hline 30 & Abte de bovinos & 610 & 758160 & 141962 & 0 & 602070 & 7400570 & 16451301 \\
\hline 31 & Ind́śstria de laticínios & 408 & 201371 & 0362 & 0 & 664240 & 6730106 & 9341548 \\
\hline 30 & Forrio $\tau^{2}$ & 1006 & (1) & 156478 & 0 & 6641241 & 402064 & 9240164 \\
\hline 3 & (1) & 1220 & (20010 & & 0 & 1846413 & 4423064 & 7801965 \\
\hline 政 & Fab. oleos vegetals & 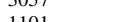 & 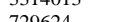 & 0.020 & 0 & 4750199 & 8140847 & 16134226 \\
\hline 25 & Raçōes & 1101 & 129024 & 636158 & 0 & 1761939 & 3149885 & 7856434 \\
\hline (3) & Outros prod. alimentares & 5743 & 1214223 & -721879 & 0 & 19813958 & 20512321 & 27774619 \\
\hline 36 & Indústrias diversas & 776030 & 945464 & -95384 & 0 & 3486235 & 5150803 & 9533101 \\
\hline 37 & S.I.U.P. & 3871 & 12821 & 252841 & 0 & 16752367 & 17037160 & 52702892 \\
\hline 38 & Construçãa civil & 125757731 & 29431 & -146584 & 0 & 12345 & 125818434 & 138922689 \\
\hline 39 & Comércio & 4067528 & 8187552 & -1316290 & 0 & 55640678 & 66606393 & 120298282 \\
\hline 40 & Transporte rodoviário & 233995 & 1530025 & -2312796 & 0 & 18636073 & 18087652 & 33721419 \\
\hline 41 & Transporte aéreo & 76361 & 970383 & 3407824 & 0 & 2365906 & 6825106 & 11131706 \\
\hline 42 & Transporte ferroviário & 22535 & 307871 & -1145308 & 0 & 258896 & -555484 & 3285050 \\
\hline 43 & Transporte aquaviário & 13421 & 236765 & 113440 & 0 & 93016 & 456835 & 1956478 \\
\hline 44 & Atividades aux. dos transp. & 60073 & 819701 & 479236 & 0 & 3208964 & 4572810 & 9829565 \\
\hline 45 & Comunicações & 47139 & 109937 & 175620 & 0 & 17816484 & 18184389 & 34999043 \\
\hline 46 & Instituições financeiras & 0 & 454730 & 341842 & 0 & 17829929 & 18659549 & 81126824 \\
\hline 47 & Serv. prest. às famílias & 11320 & 2874318 & 253874 & 0 & 72527987 & 75710805 & 93013395 \\
\hline 48 & Serv. prest. às empresas & 1409557 & 4634872 & 463112 & 0 & 1301894 & 7814575 & 49562083 \\
\hline 49 & Aluguel de imóveis & 0 & & 1191356 & 0 & 116144533 & 117553027 & 127451387 \\
\hline 50 & Administração pública & 274268 & 1234416 & 111147 & 182857042 & 2290449 & 186785386 & 197097871 \\
\hline 51 & Serv. priv. não merccantis & 0 & 0 & 18171 & 0 & 11410990 & 11429161 & 11429161 \\
\hline
\end{tabular}


APÊNDICE 1 - Matriz insumo-produto inter-regional Mato Grosso x resto do Brasil / 1999.

\begin{tabular}{|c|c|c|c|c|c|c|c|c|c|c|c|c|c|}
\hline & \multicolumn{13}{|c|}{ Mato Grosso } \\
\hline & 1 & 2 & 3 & 4 & 5 & 6 & 7 & 8 & 9 & 10 & 11 & 12 & 13 \\
\hline Produção nacional & & & & & & & & & & & & & \\
\hline $\begin{array}{l}\text { Importado } \\
\text { lad }\end{array}$ & 2709 & 22092 & 1775 & 1655 & 21522 & 1582 & 23010 & 1448 & 10359 & 2182 & 11 & 455 & 4107 \\
\hline Imposto de importação & 4 & 31 & 2 & 2 & 30 & 2 & 32 & 2 & 14 & 3 & 0 & 1 & 8 \\
\hline ICM nacional & 3153 & 25721 & 2066 & 1927 & 25057 & 1841 & 26790 & 1686 & 12061 & 2540 & 13 & 530 & 4464 \\
\hline ICM Importado & 1 & 6 & 1 & 0 & 6 & $\begin{array}{c}10+1 \\
0\end{array}$ & 6 & 0 & 3 & 1 & 0 & 0 & 0 \\
\hline IPI nacional & 91 & 744 & 60 & 56 & 725 & 53 & 775 & 49 & 349 & 73 & 0 & 15 & 570 \\
\hline IPI importação & 1 & $\begin{array}{l}744 \\
8\end{array}$ & 1 & 1 & 7 & 1 & 8 & 0 & $\begin{array}{c}3+9 \\
4\end{array}$ & 1 & 0 & 0 & $\begin{array}{c}50 \\
0\end{array}$ \\
\hline Outros IIL nacional & 13 & $\begin{array}{c}0 \\
103\end{array}$ & 8 & 8 & 101 & 7 & $\begin{array}{c}0 \\
108\end{array}$ & 7 & 48 & 10 & 0 & 2 & 65 \\
\hline Outros IIL importação & 1 & 5 & 0 & 0 & 5 & 0 & 5 & 0 & 2 & 0 & 0 & 0 & 1 \\
\hline Consumo intermediário & 93166 & 1088691 & 93187 & 46039 & 549184 & 81770 & 953771 & 62161 & 433649 & 39883 & 202 & 9085 & 114483 \\
\hline Remunerações & 19775 & 21416 & 10633 & 7142 & 89239 & 8657 & 108913 & 19916 & 102463 & 4811 & 54 & 593 & 30989 \\
\hline Salários & 16695 & 18081 & 8977 & 6030 & 75341 & 7309 & 91951 & 16815 & 86506 & 4061 & 46 & 501 & 22927 \\
\hline Contribuições sociais fictícias & 3080 & 3335 & 1656 & 1112 & 13898 & 1348 & 16962 & 3102 & 15957 & 749 & 8 & 92 & 8062 \\
\hline Previdência oficial/FGTS & 3070 & 3325 & 1651 & 1109 & 13856 & 1344 & 16911 & 3092 & 15909 & 747 & 8 & 92 & 5913 \\
\hline Previdência privada & 9 & 10 & 5 & 3 & 42 & 4 & 51 & 9 & 48 & 2 & 0 & 0 & 2150 \\
\hline Contribuições sociais fictícias & 0 & 0 & 0 & 0 & 0 & 0 & 0 & 0 & 0 & 0 & 0 & 0 & 0 \\
\hline Excedente operacional bruto (EOB) & 58559 & 481829 & 26623 & 42512 & 557215 & 25267 & 501170 & 17579 & 170419 & 57322 & 257 & 12650 & 115938 \\
\hline Rendimento de autônomos & 325 & 3901 & 303 & 188 & 2350 & 189 & 3156 & 116 & 1086 & 204 & 1 & 45 & 5082 \\
\hline EOB Exclusive rendimentos de autônomos & 58234 & 477928 & 26320 & 42324 & 554865 & 25078 & 498014 & 17464 & 169333 & 57118 & 256 & 12605 & 110856 \\
\hline Valor adicionado a custo de fatores & 78334 & 503246 & 37256 & 49654 & 646454 & 33924 & 610082 & 37496 & 272881 & 62132 & 311 & 13243 & 146928 \\
\hline Outros impostos sobre a produção & 4 & 37 & 3 & 2 & 28 & 3 & 36 & 2 & 16 & 2 & 0 & 1 & 12431 \\
\hline Outros subsídios à produção & -1372 & -12736 & -1044 & -766 & -9566 & -926 & -12512 & -797 & -5653 & -816 & -4 & -179 & 0 \\
\hline Valor adicionado a preço básico & 76966 & 490546 & 36215 & 48891 & 636916 & 33001 & 597607 & 36701 & 267245 & 61319 & 307 & 13065 & 159359 \\
\hline Valor da produção & 170131 & 1579237 & 129402 & 94930 & 1186099 & 114771 & 1551378 & 98862 & 700894 & 101202 & 510 & 22150 & 273842 \\
\hline Pessoal Ocupado & 1320 & 12866 & 27052 & 3434 & 161097 & 26754 & 79228 & 14488 & 74536 & 16236 & 51 & 235 & 6042 \\
\hline
\end{tabular}

APÊNDICE 1 - Matriz insumo-produto inter-regional Mato Grosso x resto do Brasil / 1999.

\begin{tabular}{|c|c|c|c|c|c|c|c|c|c|c|c|c|c|}
\hline & \multicolumn{13}{|c|}{ Mato Grosso } \\
\hline & 14 & 15 & 16 & 17 & 18 & 19 & 20 & 21 & 22 & 23 & 24 & 25 & 26 \\
\hline Produção nacional & & & & & & & & & & & & & \\
\hline Importado & 4128 & 160 & 35 & 12 & 35 & 1941 & 820 & 1635 & 1986 & 3906 & 1451 & 286 & \\
\hline Imposto de importação & $\begin{array}{c}4120 \\
8\end{array}$ & $\begin{array}{c}100 \\
0\end{array}$ & 0 & 0 & 0 & $\begin{array}{c}1941 \\
6\end{array}$ & $\begin{array}{c}020 \\
2\end{array}$ & $\begin{array}{c}1030 \\
5\end{array}$ & $\begin{array}{c}1900 \\
4\end{array}$ & 8 & $\begin{array}{c}1411 \\
2\end{array}$ & $\begin{array}{c}280 \\
1\end{array}$ & $\begin{array}{c}102 \\
2\end{array}$ \\
\hline ICM nacional & 7988 & 175 & 53 & 11 & 34 & 13267 & 1576 & 1418 & 5151 & 1142 & 413 & 305 & 1756 \\
\hline ICM Importado & $\begin{array}{c}9988 \\
0\end{array}$ & $\begin{array}{c}175 \\
0\end{array}$ & $\begin{array}{c}53 \\
0\end{array}$ & ${ }_{0}^{11}$ & $\begin{array}{c}34 \\
0\end{array}$ & $\begin{array}{c}1526 / \\
0\end{array}$ & $\begin{array}{c}15 / 0 \\
0\end{array}$ & $\begin{array}{c}1418 \\
0\end{array}$ & 0 & $\begin{array}{c}1142 \\
0\end{array}$ & $\begin{array}{c}413 \\
0\end{array}$ & $\begin{array}{c}305 \\
0\end{array}$ & $\begin{array}{c}1750 \\
0\end{array}$ \\
\hline $\begin{array}{l}\text { IPI nacional } \\
\text { IPI }\end{array}$ & 764 & 28 & 9 & 2 & 5 & 1229 & 216 & $\begin{array}{l}0 \\
173\end{array}$ & 362 & 89 & 55 & 38 & 121 \\
\hline IPI importação & $\begin{array}{c}104 \\
0\end{array}$ & $\begin{array}{c}28 \\
0\end{array}$ & 0 & ${ }_{0}^{2}$ & 0 & $\begin{array}{c}1229 \\
0\end{array}$ & $\begin{array}{c}216 \\
0\end{array}$ & $\begin{array}{c}173 \\
0\end{array}$ & $\begin{array}{c}302 \\
0\end{array}$ & $\begin{array}{c}89 \\
0\end{array}$ & $\begin{array}{c}53 \\
0\end{array}$ & $\begin{array}{c}38 \\
0\end{array}$ & $\begin{array}{c}121 \\
0\end{array}$ \\
\hline Outros IIL nacional & 23 & 0 & 0 & 0 & 0 & 17 & 5 & 5 & 40 & 9 & 2 & 0 & 2 \\
\hline $\begin{array}{l}\text { Outros ILL nacional } \\
\text { Outros IIL importacãão }\end{array}$ & $\begin{array}{c}23 \\
2\end{array}$ & 0 & 0 & 0 & 0 & 0 & $\begin{array}{l}5 \\
0\end{array}$ & $\begin{array}{l}5 \\
1\end{array}$ & $\begin{array}{c}40 \\
1\end{array}$ & 2 & $\begin{array}{l}2 \\
1\end{array}$ & 0 & ${ }_{0}^{2}$ \\
\hline Consumo intermediário & 140006 & 3256 & 944 & 218 & 591 & 220391 & 28049 & 34212 & 155540 & 62117 & 20241 & 6526 & 24848 \\
\hline $\begin{array}{l}\text { Remuneraçōes } \\
\text { la }\end{array}$ & 28208 & 1998 & 317 & 29 & 121 & 47210 & 5884 & 3913 & 12814 & 8228 & 2326 & 1075 & 7655 \\
\hline Salários & 20621 & 1289 & 236 & 21 & 90 & 36946 & $\begin{array}{l}5004 \\
4234\end{array}$ & 2899 & 9445 & 3807 & 1702 & 799 & 5764 \\
\hline Contribuições sociais fictícias & 7588 & 709 & 81 & 7 & 32 & 10264 & 1650 & 1013 & 3369 & 4421 & 624 & 275 & 1890 \\
\hline $\begin{array}{l}\text { Previdência oficial/FGTS } \\
\text { PFTs }\end{array}$ & 6777 & 692 & $\begin{array}{l}01 \\
79\end{array}$ & 7 & 30 & 10206 & 1581 & 931 & 3146 & 1272 & 573 & 251 & 1845 \\
\hline Previdência privada & 811 & 18 & 2 & 1 & 1 & 58 & 70 & 83 & 224 & 3149 & 51 & 25 & 45 \\
\hline Contribuições sociais fictícias & 0 & 0 & 0 & 0 & 0 & 0 & 0 & 0 & 0 & 0 & 0 & 0 & 0 \\
\hline Excedente operacional bruto (EOB) & 38673 & 843 & 557 & 29 & 45 & 93376 & 2902 & 8942 & 63396 & 14500 & 765 & 2547 & 8149 \\
\hline Rendimento de autônomos & 520 & 0 & 0 & 0 & 0 & 16097 & 164 & 0 & 0 & 0 & 0 & 0 & 448 \\
\hline EOB Exclusive rendimentos de autônomos & 38153 & 843 & 557 & 29 & 45 & 77280 & 2738 & 8942 & 63396 & 14500 & 765 & 2547 & 7701 \\
\hline Valor adicionado a custo de fatores & 66881 & 2841 & 873 & 57 & 167 & 140586 & 8786 & 12854 & 76211 & 22728 & 3091 & 3622 & 15804 \\
\hline Outros impostos sobre a produção & 10090 & 315 & 94 & 14 & 39 & $\begin{array}{l}170000 \\
15062\end{array}$ & 1803 & 2353 & 11464 & 4119 & 1175 & 506 & 1910 \\
\hline Outros subsídios à produção & 0 & -31 & -9 & -1 & -12 & 0 & 0 & 0 & 0 & 0 & 0 & 0 & 0 \\
\hline $\begin{array}{l}\text { Valor adicionado a preço básico } \\
\text { Vidion }\end{array}$ & 76972 & 3126 & 958 & $\begin{array}{l}-1 \\
70\end{array}$ & $\begin{array}{l}-12 \\
193\end{array}$ & 155648 & 10589 & 15207 & 87675 & 26847 & 4266 & 4128 & 17714 \\
\hline Valor da produção areço dasico & 216978 & $\begin{array}{l}3120 \\
6382\end{array}$ & 1902 & 289 & 785 & 376039 & $\begin{array}{l}10589 \\
38638\end{array}$ & 49419 & 243215 & $\begin{array}{l}28041 \\
88964\end{array}$ & 24508 & $\begin{array}{l}4128 \\
10654\end{array}$ & 42562 \\
\hline $\begin{array}{l}\text { Pessoal Ocupado } \\
\text { Pal }\end{array}$ & 7100 & 336 & 420 & 15 & 7 & 24474 & 1813 & 5047 & 803 & 231 & 226 & 1827 & 3499 \\
\hline
\end{tabular}


APÊNDICE 1 - Matriz insumo-produto inter-regional Mato Grosso x resto do Brasil / 1999.

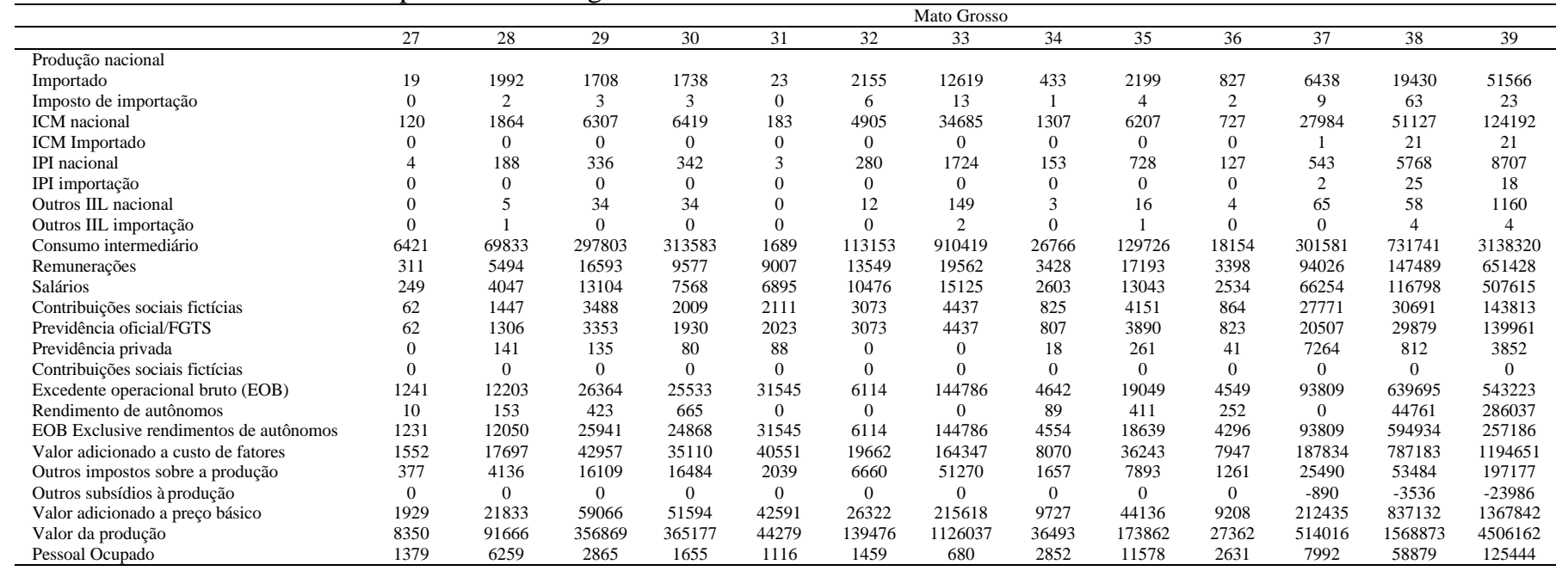

APÊNDICE 1 - Matriz insumo-produto inter-regional Mato Grosso x resto do Brasil / 1999.

\begin{tabular}{|c|c|c|c|c|c|c|c|c|c|c|c|c|}
\hline \multirow{3}{*}{$\begin{array}{l}\text { Produç̃o nacional } \\
\end{array}$} & \multicolumn{12}{|c|}{ Mato Grosso } \\
\hline & 40 & 41 & 42 & 43 & 44 & 45 & 46 & 47 & 48 & 49 & 50 & 51 \\
\hline & & & & & & & & & & & & \\
\hline Importado & 16182 & 1473 & 423 & 256 & 1421 & 3544 & 3566 & 18037 & 4059 & 194 & 26716 & 211 \\
\hline Imposto de importação & 20 & 2 & 2 & 0 & 2 & 9 & 2 & 40 & 6 & 0 & 22 & 0 \\
\hline ICM nacional & 19869 & 1018 & 345 & 160 & 2280 & 2337 & 2594 & 42758 & 6689 & 356 & 20352 & 680 \\
\hline ICM Importado & 9 & 1 & 0 & 0 & 1 & 4 & 2 & 17 & 4 & 0 & 22 & 0 \\
\hline IPI nacional & 1278 & 40 & 19 & 4 & 308 & 340 & 708 & 5640 & 674 & 50 & 3756 & 39 \\
\hline IPI importação & 4 & 0 & 0 & 0 & 0 & 3 & 2 & 15 & 4 & 0 & 18 & 0 \\
\hline Outros IIL nacional & 83 & 8 & 2 & 1 & 7 & 45 & 97 & 73 & 32 & 10 & 221 & 0 \\
\hline Outros IIL importaçãa & 3 & 0 & 0 & 0 & 0 & 0 & 0 & 4 & 1 & 0 & 4 & 0 \\
\hline Consumo intermediário & 378316 & 40580 & 8793 & 6286 & 31387 & 62731 & 127579 & 561857 & 119578 & 26804 & 718064 & 9886 \\
\hline Remunerações & 129278 & 11692 & 3450 & 2055 & 15726 & 90324 & 153330 & 469456 & 155667 & 6383 & 2530995 & 140490 \\
\hline Salários & 97842 & 8849 & 2611 & 1555 & 11988 & 68284 & 124373 & 357478 & 117072 & 5351 & 1504957 & 117816 \\
\hline Contribuições sociais fictícias & 31436 & 2843 & 839 & 500 & 3738 & 22040 & 28957 & 111978 & 38595 & 1031 & 154607 & 22674 \\
\hline Previdência oficial/FGTS & 28383 & 2567 & 758 & 451 & 3529 & 19066 & 23485 & 109117 & 37452 & 1031 & 152774 & 21919 \\
\hline Previdência privada & 3052 & 276 & 81 & 49 & 209 & 2973 & 5472 & 2861 & 1143 & 0 & 1833 & 756 \\
\hline Contribuições sociais fictícias & 0 & 0 & 0 & 0 & 0 & 0 & 0 & 0 & 0 & 0 & 871431 & 0 \\
\hline Excedente operacional bruto (EOB) & 100712 & 6319 & 5594 & 2430 & 14168 & 195076 & 95061 & 292193 & 116769 & 497561 & 0 & 0 \\
\hline Rendimento de autônomos & 55279 & 3468 & 2898 & 563 & 8122 & 0 & 12024 & 224308 & 33144 & 1932 & 0 & 0 \\
\hline EOB Exclusive rendimentos de autônomos & 45432 & 2850 & 2695 & 1867 & 6045 & 195076 & 83037 & 67885 & 83625 & 495628 & 0 & 0 \\
\hline Valor adicionado a custo de fatores & 229990 & 18010 & 9044 & 4485 & 29894 & 285400 & 248392 & 761649 & 272436 & 503943 & 2530995 & 140490 \\
\hline Outros impostos sobre a produção & 20660 & 3506 & 488 & 143 & 2421 & 18519 & 19238 & 27267 & 14021 & 5325 & 20233 & 1333 \\
\hline Outros subsídios à produção & -9465 & -856 & -253 & -150 & -611 & -457 & 0 & -1 & 0 & 0 & 0 & 0 \\
\hline Valor adicionado a preço básico & 241184 & 20661 & 9279 & 4478 & 31703 & 303462 & 267630 & 788916 & 286457 & 509268 & 2551228 & 141823 \\
\hline Valor da & 619500 & 61240 & 18072 & 10763 & 63090 & 366193 & 395209 & 1350773 & 406034 & 536072 & 3269292 & 151709 \\
\hline Pessoal Ocupado & 18848 & 459 & 413 & 306 & 3872 & 1458 & 4103 & 115551 & 21704 & 1162 & 94720 & 89440 \\
\hline
\end{tabular}


APÊNDICE 1 - Matriz insumo-produto inter-regional Mato Grosso x resto do Brasil / 1999.

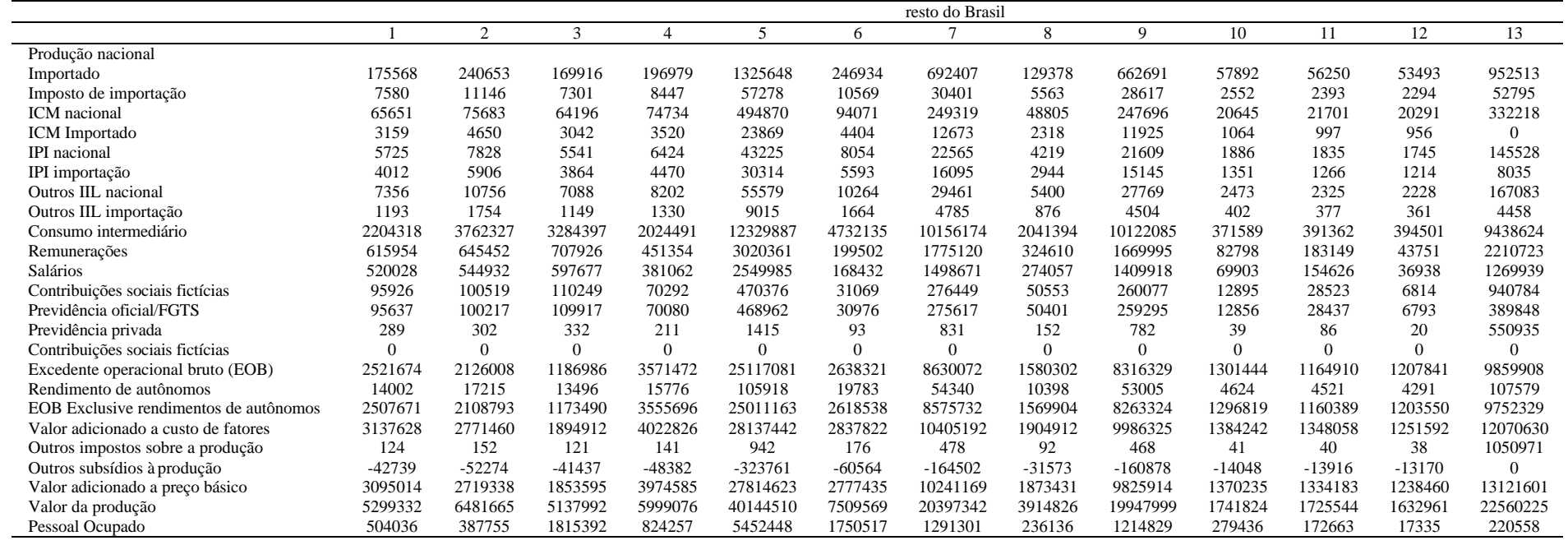

APÊNDICE 1 - Matriz insumo-produto inter-regional Mato Grosso x resto do Brasil / 1999.

\begin{tabular}{|c|c|c|c|c|c|c|c|c|c|c|c|c|c|}
\hline \multirow{2}{*}{ 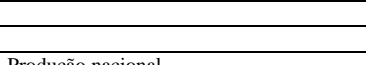 } & \multicolumn{13}{|c|}{$\begin{array}{l}\text { resto do Brasil } \\
20\end{array}$} \\
\hline & 14 & 15 & 16 & 17 & 18 & 19 & 20 & 21 & 22 & 23 & 24 & 25 & 26 \\
\hline & & & & & & & & & & & & & \\
\hline & 5778368 & 115663 & 1168182 & 3140186 & 5511783 & 446224 & 1663359 & 3884621 & 173393 & 8272635 & 1174892 & 1176971 & 2805481 \\
\hline Imposto de importação & 333347 & 8142 & 105984 & 299771 & 383467 & 39787 & 109068 & 346750 & 11883 & 536449 & 53497 & 75700 & 260400 \\
\hline ICM nacional & 2278886 & 41738 & 580835 & 894449 & 1699786 & 447368 & 1013787 & 928820 & 145601 & 800757 & 110577 & 416352 & 1179804 \\
\hline ICM Importado & 0 & 0 & 0 & $87+47$ & 0 & 471000 & 0 & $\begin{array}{l}2000 \\
0\end{array}$ & 0 & 0 & 0 & 41000 & 0 \\
\hline $\begin{array}{l}\text { IPI nacional } \\
\text { L }\end{array}$ & 807183 & 19795 & 275136 & 476842 & 696724 & 123088 & 407205 & 330178 & 30633 & 183370 & 43252 & 152385 & 158676 \\
\hline IPI importação & 4060 & 106 & 1065 & 1544 & 3337 & 786 & 1557 & 1316 & 124 & 1024 & 186 & 839 & 1347 \\
\hline Outros IIL nacional & 248805 & 2428 & 36790 & 95708 & 118246 & 14620 & 79059 & 92955 & 31147 & 159503 & 14851 & 220 & 62553 \\
\hline Outros IIL importação & 80421 & 832 & 8391 & 23041 & 47330 & 2509 & 10291 & 43995 & 2094 & 101552 & 16790 & 8997 & 15360 \\
\hline Consumo intermediário & 65044627 & 879913 & 11795439 & 18597956 & 31399637 & 9367002 & 20751029 & 29058650 & 4989250 & 49256843 & 6129646 & 10069839 & 27415291 \\
\hline Remunerações & 8508678 & 624858 & 4620416 & 2696433 & 4793742 & 2683932 & 4234312 & 4693236 & 447732 & 1590032 & 726160 & 1821274 & 4383074 \\
\hline Salários & 6348975 & 403009 & 3442863 & 2004075 & 3531740 & 2100222 & 3165102 & 3456720 & 330004 & 735745 & 531270 & 1354675 & 3356260 \\
\hline Contribuições sociais fictícias & 2159702 & 221849 & 1177553 & 692359 & 1262001 & 583710 & 1069210 & 1236516 & 117728 & 854287 & 194889 & 466600 & 1026815 \\
\hline Previdência oficial/FGTS & 1990940 & 216319 & 1148203 & 627750 & 1188258 & 570503 & 1024082 & 1153612 & 109911 & 245780 & 178866 & 424778 & 1009094 \\
\hline Previdência privada & 168762 & 5529 & 29350 & 64608 & 73743 & 13207 & 45127 & 82904 & 7816 & 608507 & 16024 & 41821 & 17721 \\
\hline Contribuições sociais fictícias & & 0 & 0 & 0 & 0 & 0 & 0 & 0 & 0 & 0 & 0 & 0 & \\
\hline Excedente operacional bruto (EOB) & 14308659 & 402226 & 10096818 & 4701483 & 5273365 & 3331957 & 3304661 & 9381654 & 2660454 & 20815122 & 427573 & 5305710 & 4927923 \\
\hline Rendimento de autônomos & 451546 & 0 & 0 & 0 & 0 & 609351 & 164616 & 0 & 0 & 0 & 0 & 0 & 1619431 \\
\hline EOB Exclusive rendimentos de autônomos & 13857113 & 402226 & 10096818 & 4701483 & 5273365 & 2722605 & 3140044 & 9381654 & 2660454 & 20815122 & 427573 & 5305710 & 3308492 \\
\hline Valor adicionado a custo de fatores & 22817337 & 1027084 & 14717234 & 7397917 & 10067106 & 6015889 & 7538973 & 14074890 & 3108185 & 22405154 & 1153733 & 7126984 & 9310997 \\
\hline Outros impostos sobre a produção & 4244977 & 98655 & 1371588 & 1305889 & 2086432 & 641883 & 1384515 & 2180523 & 400562 & 3478710 & 366933 & 857765 & 1629669 \\
\hline Outros subsídios à produção & -224 & -9554 & -132828 & -52131 & -333624 & 0 & 0 & 0 & 0 & 0 & 0 & 0 & 0 \\
\hline Valor adicionado a preço básico & 27062089 & 1116185 & 15955994 & 8651675 & 11819915 & 6657772 & 8923488 & 16255413 & 3508748 & 25883864 & 1520666 & 7984749 & 10940666 \\
\hline Valor da produção & 92106716 & 1996098 & 27751433 & 27249630 & 43219551 & 16024774 & 29674517 & 45314062 & 8497998 & 75140707 & 7650311 & 18054588 & 38355957 \\
\hline Pessoal Ocupado & 1151700 & 25298 & 354847 & 208485 & 279793 & 787926 & 415487 & 400460 & 28064 & 44669 & 26801 & 117573 & 2020001 \\
\hline
\end{tabular}


APÊNDICE 1 - Matriz insumo-produto inter-regional Mato Grosso x resto do Brasil / 1999.

\begin{tabular}{|c|c|c|c|c|c|c|c|c|c|c|c|c|c|}
\hline \multirow{2}{*}{ r } & \multirow{2}{*}{\multicolumn{13}{|c|}{$\begin{array}{ll}\text { resto do Brasil } \\
33\end{array}$}} \\
\hline & & 28 & 29 & 30 & 31 & 32 & & 34 & 35 & 36 & 37 & 38 & 39 \\
\hline $\begin{array}{l}\text { Produção nacional } \\
\text { Importado }\end{array}$ & 63920 & & & & & & & & & & & & \\
\hline Imposto de importação & $\begin{array}{l}03920 \\
2600\end{array}$ & $\begin{array}{l}1486061 \\
38845\end{array}$ & $\begin{array}{l}200897 \\
9376\end{array}$ & $\begin{array}{l}18731 \\
5454\end{array}$ & $\begin{array}{c}262653 \\
8998\end{array}$ & $\begin{array}{l}3116500 \\
27134\end{array}$ & $\begin{array}{l}468390 \\
15826\end{array}$ & $\begin{array}{l}236667 \\
12693\end{array}$ & $\begin{array}{l}879300 \\
45168\end{array}$ & 40229 & $\begin{array}{c}1377809 \\
61309\end{array}$ & $\begin{array}{l}4189944 \\
416076\end{array}$ & $\begin{array}{c}2646304 \\
40729\end{array}$ \\
\hline ICM nacional & 130863 & 459810 & 249034 & 141040 & 688347 & 234084 & 419980 & 235996 & 834071 & 207887 & 1966499 & 3620503 & 2046606 \\
\hline ICM Importado & 0 & $\begin{array}{c}499010 \\
0\end{array}$ & $\begin{array}{c}249034 \\
0\end{array}$ & $\begin{array}{l}140+0 \\
0\end{array}$ & 0 & $\begin{array}{c}23004 \\
0\end{array}$ & $\begin{array}{c}419900 \\
0\end{array}$ & 0 & $\begin{array}{c}050 / 1 \\
0\end{array}$ & 0 & 15246 & 288824 & $\begin{array}{l}6840072 \\
6862\end{array}$ \\
\hline IPI nacional & 12526 & 135957 & 39470 & 22646 & 30055 & 39609 & 64324 & 81180 & 287232 & 106363 & 112513 & 1204825 & 444034 \\
\hline IPI importação & $\begin{array}{l}12206 \\
466\end{array}$ & 1528 & $\begin{array}{l}3940 \\
1067\end{array}$ & $\begin{array}{l}22040 \\
616\end{array}$ & 338 & 1328 & $\begin{array}{c}04249 \\
749\end{array}$ & $\begin{array}{l}8180 \\
205\end{array}$ & $\begin{array}{c}281252 \\
764\end{array}$ & $\begin{array}{l}10303 \\
4536\end{array}$ & 23191 & 349636 & $\begin{array}{l}42332 \\
6232\end{array}$ \\
\hline Outros IIL nacional & 10453 & 34954 & 36193 & 20886 & 12286 & 15064 & 51980 & 16401 & 57711 & 29781 & 123162 & 111070 & 550084 \\
\hline Outros IIL importação & 284 & 29809 & 1026 & 592 & 1503 & 2042 & 2728 & 2023 & 7526 & 4363 & 1296 & 28129 & 6571 \\
\hline Consumo intermediário & 7915195 & 19480260 & 13515764 & 7827891 & 7169422 & 6117719 & 12577648 & 5465052 & 19850111 & 5870188 & 24027179 & 58660037 & 60261438 \\
\hline Remunerações & 400268 & 1603621 & 842148 & 475440 & 453453 & 682144 & 280284 & 737912 & 2746506 & 1183940 & 9878023 & 9643866 & 29404286 \\
\hline Salários & 320401 & 1181367 & 665089 & 375695 & 347165 & 527426 & 216713 & 560336 & 2083584 & 882989 & 6960456 & 7637092 & 22912833 \\
\hline Contribuiç̃os sociais fictícias & 79867 & 422254 & 177059 & 99745 & 106289 & 154718 & 63571 & 177576 & 662921 & 300951 & 2917568 & 2006774 & 6491453 \\
\hline $\begin{array}{l}\text { Previdência oficial/FGTS } \\
\text { PTS }\end{array}$ & 79867 & 381204 & 170214 & 95794 & 101839 & 154718 & 63571 & 173762 & 621180 & 286581 & 2154432 & 1953680 & 6317581 \\
\hline Previdência privada & 0 & 41050 & 6845 & 3951 & 4450 & 0 & 0 & 3814 & 41742 & $\begin{array}{l}200301 \\
14370\end{array}$ & 763136 & 53094 & 173872 \\
\hline Jes sociais fictícias & 0 & 0 & $\begin{array}{c}0.5 \\
0\end{array}$ & 0 & 0 & 0 & 0 & 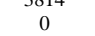 & 0 & 0 & 0 & 0 & 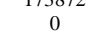 \\
\hline Excedente operacional bruto (EOB) & 1949185 & 4465882 & 1350764 & 616532 & 1191710 & 629559 & 2541677 & 1296797 & 3917071 & 2039494 & 16254778 & 66195885 & 26341047 \\
\hline $\begin{array}{l}\text { Rendimento de autônomos } \\
\text { Rent }\end{array}$ & 15987 & 56030 & 28514 & 16047 & 0 & 0 & 0 & 24743 & 87515 & $\begin{array}{l}2039494 \\
113077\end{array}$ & 0 & 4631849 & $\begin{array}{l}20341041 \\
1648665\end{array}$ \\
\hline EOB Exclusive rendimentos de autônomos & 1933198 & 4409852 & 1322249 & 600485 & 1191710 & 629559 & 2541677 & 1272055 & 3829556 & 1926418 & 16254778 & 61564036 & $\begin{array}{l}104 / 7003 \\
9862382\end{array}$ \\
\hline Valor adicionado a custo de fatores & 2349453 & 6069503 & 2192912 & 1091972 & 1645164 & 1311704 & 2821962 & 2034710 & 6663577 & 3223434 & 26132802 & 75839752 & 55745333 \\
\hline Outros impostos sobre a produção & 484941 & 1207366 & 742625 & 421685 & 425578 & 372543 & 734617 & 356672 & 1260931 & 439479 & 2613582 & 4735977 & 4911018 \\
\hline Outros subsídios à produção & 0 & 0 & 0 & 0 & 0 & 0 & 0 & 0 & 0 & 0 & -70670 & -313076 & -619507 \\
\hline Valor adicionado a preço básico & 2834394 & 7276869 & 2935537 & 1513657 & 2070741 & 1684247 & 3556578 & 2391381 & 7924507 & 3662913 & 28675713 & 80262652 & 60036844 \\
\hline Valor da produçãao & 10749589 & 26757129 & 16451301 & 9341548 & 9240164 & 7801965 & 16134226 & 7856434 & 27774619 & 9533101 & 52702892 & 138922689 & 120298282 \\
\hline Pessoal Ocupado & 69421 & 315141 & 144266 & 83314 & 56184 & 73441 & 34220 & 143593 & 506977 & 274969 & 207508 & 3849921 & 9198456 \\
\hline
\end{tabular}

APÊNDICE 1 - Matriz insumo-produto inter-regional Mato Grosso x resto do Brasil / 1999.

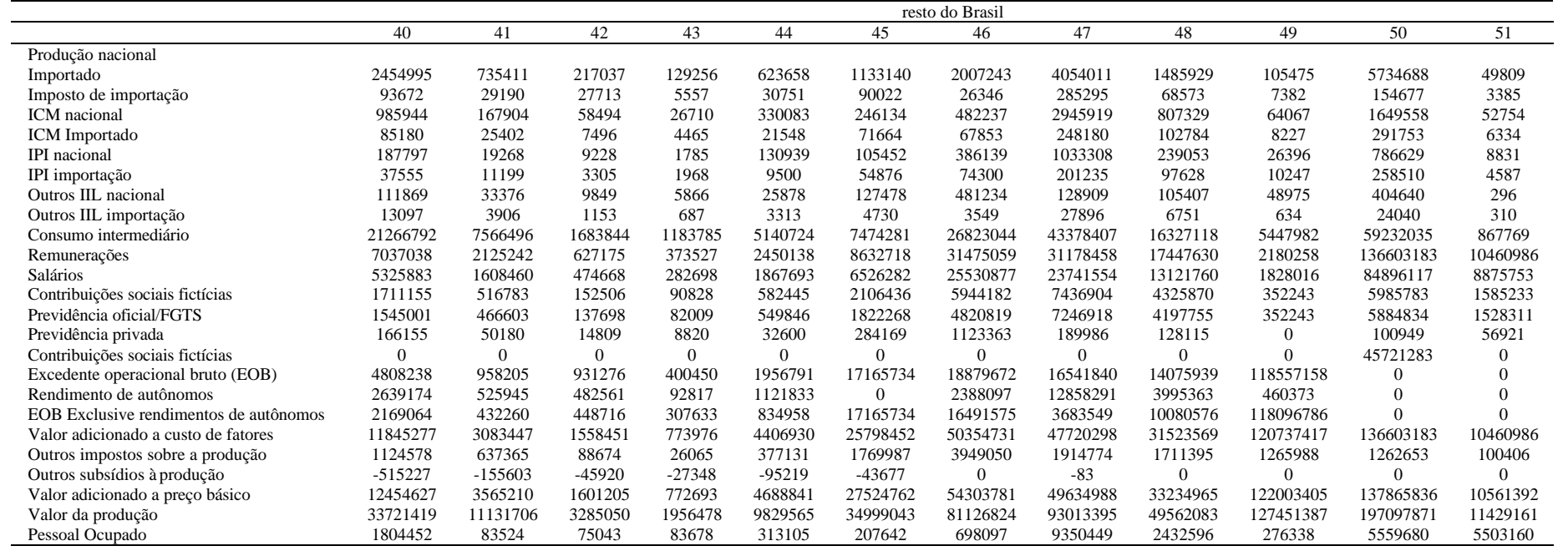


APÊNDICE 1 - Matriz insumo-produto inter-regional Mato Grosso x resto do Brasil / 1999.

\begin{tabular}{|c|c|c|c|c|c|c|c|c|}
\hline & MT & $\mathrm{RBr}$ & & & & MT & & \\
\hline & Dummy & Dummy & CI total & $\begin{array}{c}\begin{array}{c}\text { Form bruta de } \\
\text { capital fixo }\end{array} \\
\end{array}$ & Exportação & $\begin{array}{c}\text { Variação de } \\
\text { estoque }\end{array}$ & $\begin{array}{l}\text { Consumo da } \\
\text { adm. pública }\end{array}$ & $\begin{array}{c}\text { Consumo das } \\
\text { famílias }\end{array}$ \\
\hline \multicolumn{7}{|l|}{ Producão nacional } & & \\
\hline Importado & 0 & 0 & 72275087 & 133267 & 0 & 0 & 0 & \\
\hline Imposto de importação & 0 & 0 & 4338587 & 13686 & 0 & 0 & 0 & 30096 \\
\hline ICM nacional & 0 & 0 & 31907094 & 20722 & 74636 & 0 & 0 & 370864 \\
\hline ICM Importado & 0 & 0 & 1386333 & 6240 & 0 & 0 & 0 & 17584 \\
\hline IPI nacional & 0 & 0 & 9534622 & 10269 & 27553 & 0 & 0 & 96260 \\
\hline IPI importação & 0 & 0 & 1329291 & 9706 & 0 & 0 & 0 & 12393 \\
\hline Outros IIL nacional & 0 & 0 & 3849374 & 56 & 3488 & 0 & 0 & 29926 \\
\hline Outros IIL importação & 0 & 0 & 571481 & 599 & 0 & 0 & 0 & 908 \\
\hline Consumo intermediário & 199817 & 41017687 & 844769350 & 1827153 & 1685209 & -1664318 & 3001441 & 8763541 \\
\hline Remunerações & 0 & 0 & 367922157 & 0 & 0 & 0 & 0 & 0 \\
\hline Salários & 0 & 0 & 262615318 & 0 & 0 & 0 & 0 & 0 \\
\hline Contribuições sociais fictícias & 0 & 0 & 58714125 & 0 & 0 & 0 & 0 & 0 \\
\hline Previdência oficial/FGTS & 0 & 0 & 53682860 & 0 & 0 & 0 & 0 & 0 \\
\hline Previdência privada & 0 & 0 & 5031265 & 0 & 0 & 0 & 0 & 0 \\
\hline Contribuições sociais fictícias & 0 & 0 & 46592714 & 0 & 0 & 0 & 0 & 0 \\
\hline Excedente operacional bruto (EOB) & -199817 & -41017687 & 441188831 & 0 & 0 & 0 & 0 & 0 \\
\hline Rendimento de autônomos & 0 & 0 & 49995487 & 0 & 0 & 0 & 0 & 0 \\
\hline EOB Excl. rend. de autônomos & -199817 & -41017687 & 391193344 & 0 & 0 & 0 & 0 & 0 \\
\hline Valor adicionado a custo de fatores & -199817 & -41017687 & 809110988 & 0 & 0 & 0 & 0 & 0 \\
\hline Outros impostos sobre a produção & 0 & 0 & 54615666 & 0 & 0 & 0 & 0 & 0 \\
\hline Outros subsídios à produção & 0 & 0 & -3468563 & 0 & 0 & 0 & 0 & 0 \\
\hline Valor adicionado a preço básico & -199817 & -41017687 & 860258091 & 0 & 0 & 0 & 0 & 0 \\
\hline Valor da produção & 0 & 0 & 1705027441 & 0 & 0 & 0 & 0 & 0 \\
\hline Pessoal Ocupado & 0 & 0 & 62418900 & 0 & 0 & 0 & 0 & 0 \\
\hline
\end{tabular}

APÊNDICE 1 - Matriz insumo-produto inter-regional Mato Grosso x resto do Brasil / 1999.

\begin{tabular}{|c|c|c|c|c|c|c|c|}
\hline \multicolumn{8}{|c|}{$\mathrm{RBr}$} \\
\hline & $\begin{array}{l}\text { Form bruta de capital } \\
\text { fixo }\end{array}$ & Exportação & Variação de estoque & $\begin{array}{l}\text { Consumo da adm. } \\
\text { pública }\end{array}$ & $\begin{array}{l}\text { Consumo das } \\
\text { famílias }\end{array}$ & Demanda final & Demanda total \\
\hline $\begin{array}{l}\text { Produção nacional } \\
\text { Importado }\end{array}$ & 13293485 & 0 & 0 & 0 & 28835479 & 42681654 & 114956741 \\
\hline Imposto de importação & 1365187 & 0 & 0 & 0 & 2058685 & 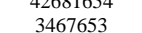 & $\begin{array}{l}114950 / 41 \\
7806240\end{array}$ \\
\hline ICM nacional & 2066988 & 4360797 & 0 & 0 & 25017507 & 31911514 & 63818609 \\
\hline ICM Importado & 622467 & 0 & 0 & 0 & 1186394 & 1832684 & 3219017 \\
\hline IPI nacional & 1024309 & 1609881 & 0 & 0 & 6500927 & 9269199 & 18803821 \\
\hline IPI importacão & 968175 & 0 & 0 & 0 & 839162 & 1829436 & 3158726 \\
\hline Outros IIL nacional & 5615 & 203787 & 0 & 0 & 2016139 & 2259011 & 6108385 \\
\hline $\begin{array}{l}\text { Outros IIL importaçãa } \\
\text { Outros }\end{array}$ & 59787 & 2038 & 0 & 0 & $\begin{array}{l}2010139 \\
62874\end{array}$ & 124169 & $\begin{array}{l}1083850 \\
695650\end{array}$ \\
\hline Consumo intermediário & 182259903 & 98462758 & 12117306 & 182857042 & 589515245 & 1078825280 & 1923594630 \\
\hline Remuneracōes & 0 & 0 & 0 & 0 & 0 & 0 & 367922157 \\
\hline Salários & 0 & 0 & 0 & 0 & 0 & 0 & 262615318 \\
\hline Contribuições sociais fictícias & 0 & 0 & 0 & 0 & 0 & 0 & 58714125 \\
\hline $\begin{array}{l}\text { Previdência oficial/FGTS } \\
\text { Pas }\end{array}$ & 0 & 0 & 0 & 0 & 0 & 0 & 53682860 \\
\hline $\begin{array}{l}\text { Previdência privada } \\
\text { Piss }\end{array}$ & 0 & 0 & 0 & 0 & 0 & 0 & 5031265 \\
\hline Contribuições sociais fictícias & 0 & 0 & 0 & 0 & 0 & 0 & 46592714 \\
\hline Excedente operacional bruto (EOB) & 0 & 0 & 0 & 0 & 0 & 0 & 441188831 \\
\hline Rendimento de autônomos & 0 & 0 & 0 & 0 & 0 & 0 & 49995487 \\
\hline EOB Excl. rend. de autônomos & 0 & 0 & 0 & 0 & 0 & 0 & 391193344 \\
\hline Valor adicionado a custo de fatores & 0 & 0 & 0 & 0 & 0 & 0 & 809110988 \\
\hline Outros impostos sobre a produção & 0 & 0 & 0 & 0 & 0 & 0 & 54615666 \\
\hline Outros subsídios à produção & 0 & 0 & 0 & 0 & 0 & 0 & -3468563 \\
\hline Valor adicionado a preço básico & 0 & 0 & 0 & 0 & 0 & 0 & 860258091 \\
\hline Valor da produção & 0 & 0 & 0 & 0 & 0 & 0 & 1705027441 \\
\hline Pessoal Ocupad & 0 & 0 & 0 & 0 & 0 & 0 & 62418900 \\
\hline
\end{tabular}


APÊNDICE 2 - Demonstração do enfoque setor x setor da tecnologia baseada na indústria:

Definem-se inicialmente as matrizes:

$$
\begin{aligned}
& B=U(\hat{X})^{-1} \quad \text { onde } \quad b_{i j}=\frac{u_{i j}}{X_{j}} \\
& D=V(\hat{Q})^{-1} \quad \text { onde } \quad d_{i j}=\frac{v_{i j}}{Q_{j}}
\end{aligned}
$$

Ao admitir-se que:

$\mathrm{m}$ equivale ao número de produtos

$\mathrm{n}$ equivale ao número de setores

B é a matriz de dimensão $\mathrm{m} \times \mathrm{n}$, cujos coeficientes $b_{i j}$ são os coeficientes técnicos da matriz de usos e recursos, obtida pós-multiplicando-se a matriz de usos pela inversa diagonalizada da matriz X (produção total por setor), disponível pelo IBGE.

$\mathrm{D}$ é a matriz de transformação $\mathrm{n}$ x m, obtida pós-multiplicando a matriz de produção pela inversa diagonalizada da matriz Q, utilizada para transformar produto em setor (quando pré-multiplicando) e setor em produto (quando pós-multiplicando). Seus coeficientes $d_{i j}$, ao longo das colunas fornecem o quanto cada setor participa da produção de cada produto no mercado.

Sabendo-se que $\mathrm{X}$ representa o produto por setor, tem-se que: $X=D * Q$.

Uma vez que $Q=U_{i}+E$ refere-se àprodução total da economia por produto e 


$$
B=U(\hat{X})^{-1} \text { aos coeficientes técnicos da matriz de usos, ao substituir }
$$

$U=B\left(\hat{X}_{i}\right)$ em $\mathrm{Q}$, obtém-se $Q=B X+E$. Assim, ao pré-multiplicar Q por $\mathrm{D}$, tem-se $D Q=D B X+D E$.

Como $D Q=X$ e $D E=Y$, tem-se que $X=D B X+Y$. Colocando todos os termos que contém $\mathrm{X}$ do lado esquerdo do sinal de igual e colocando $\mathrm{X}$ em evidência, obtém-se

$$
(I-D B) X=Y \text {. Isolando } \mathrm{X}: \quad X=(I-D B)^{-1} Y \text {, onde DB é similar à matriz de }
$$
coeficientes técnicos diretos $(\mathrm{A}) \mathrm{e}(I-D B)^{-1}$ é similar à matriz inversa de Leontief. 
APÊNDICE 3 - Mapa do Amazonas.

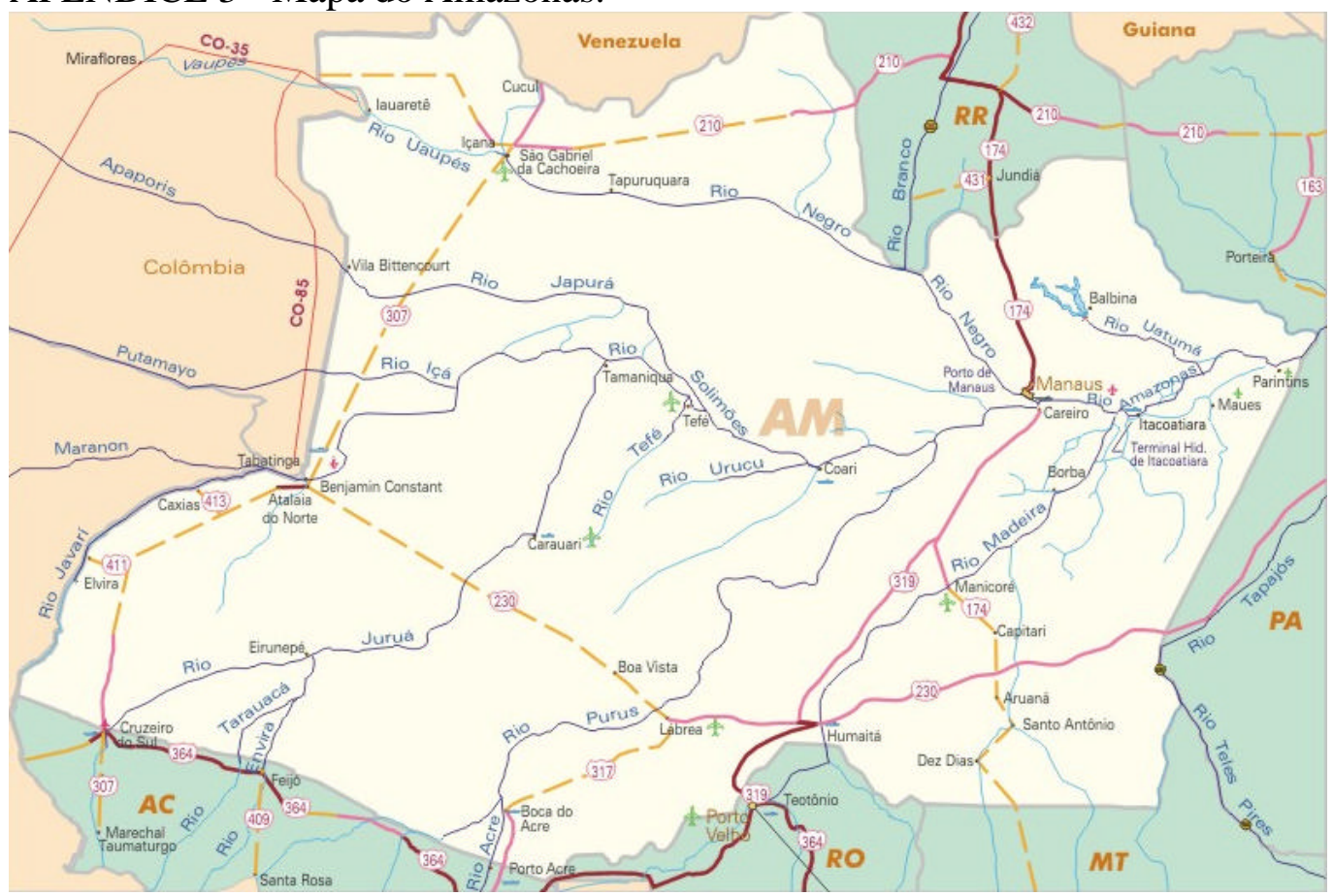

APÊNDICE 4 - Mapa do Mato Grosso.

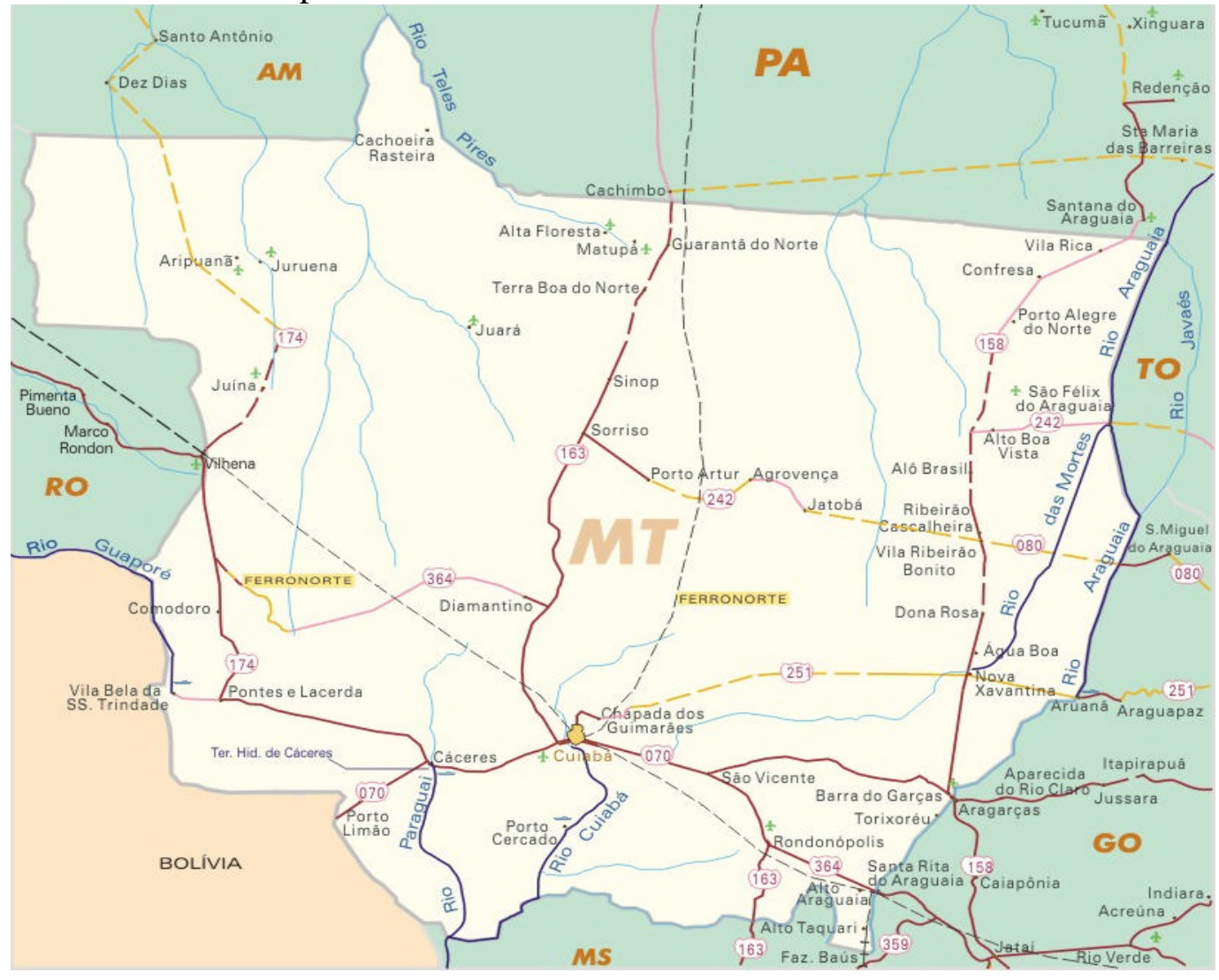


APÊNDICE 5 - Mapa de Rondônia.

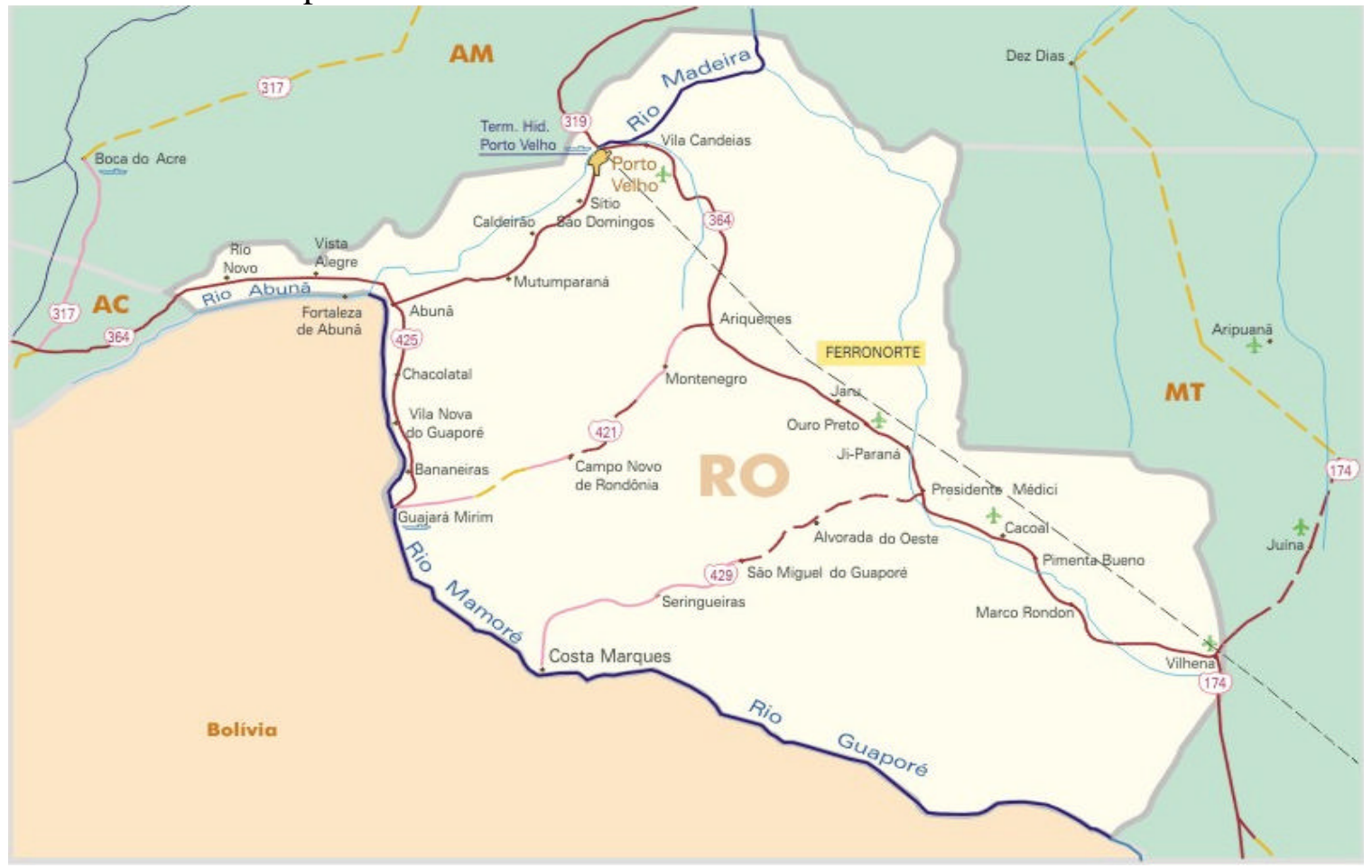

APÊNDICE 6 - Mapa de Goiás.

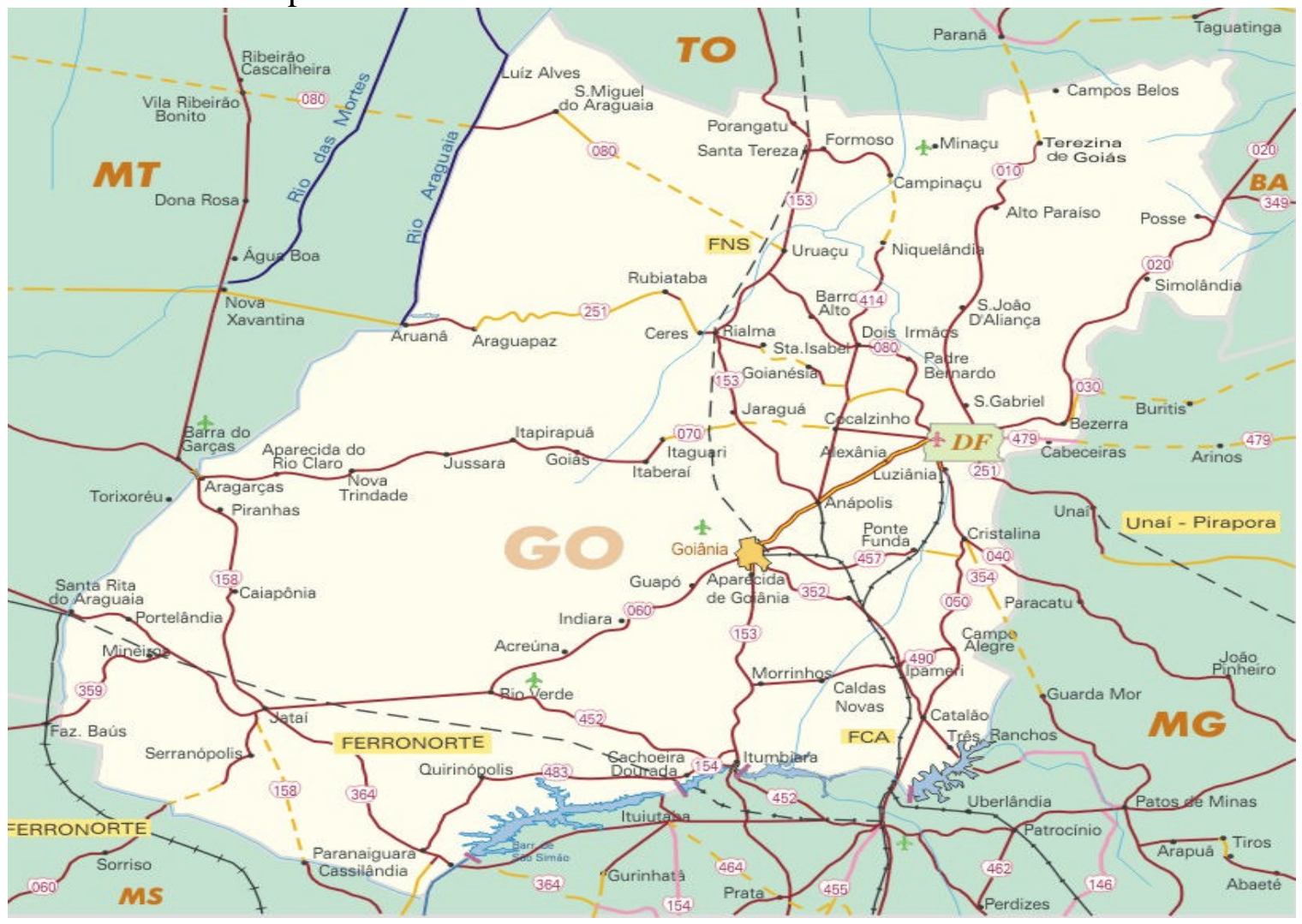


APÊNDICE 7 - Mapa do Tocantins.

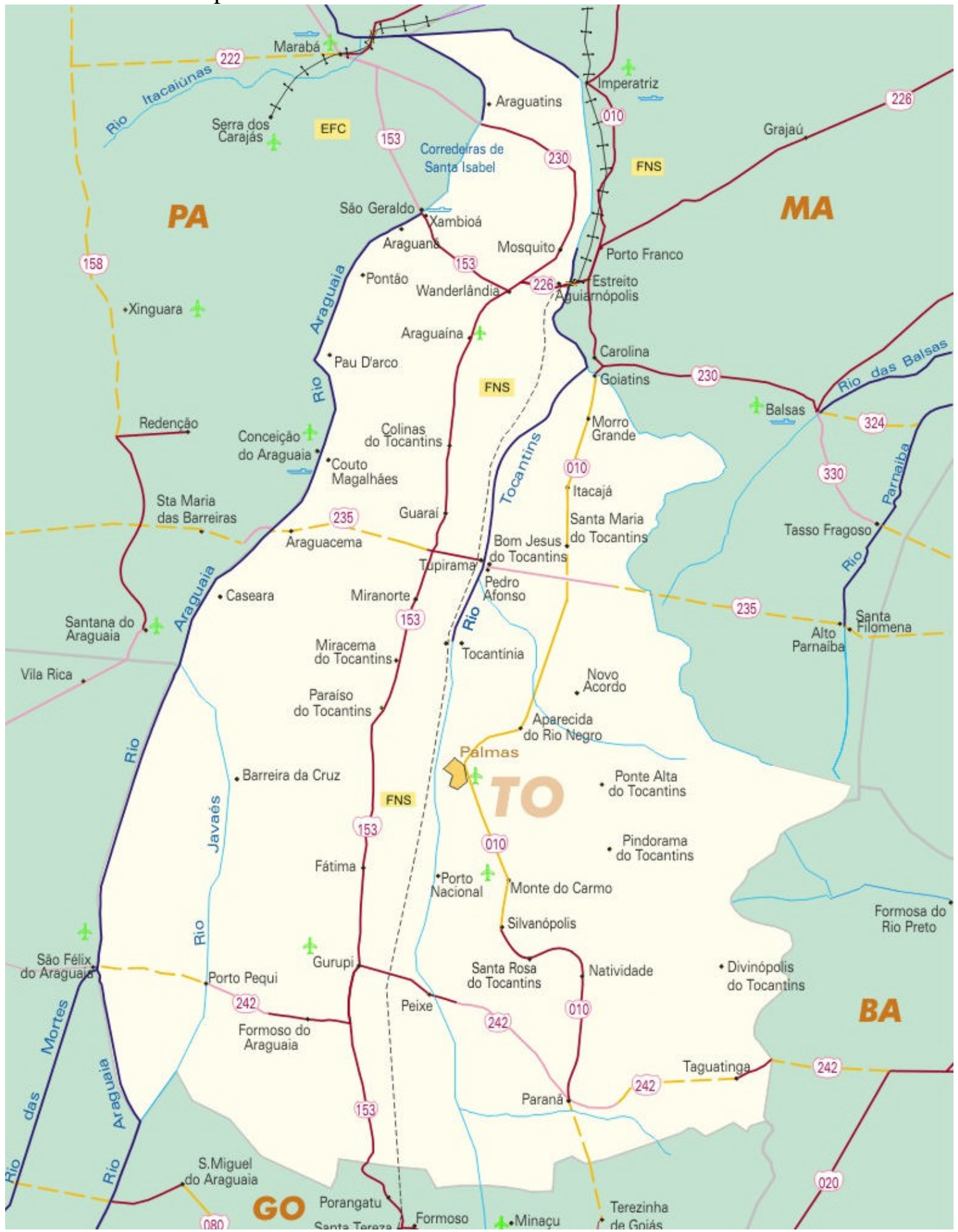

Fonte: Brasil (2003) 